\section{Pacific Northwest}

National Laboratory

Operatud by Batielle for the

U.5. Department of Energy

\title{
FY 2002 Integrated Monitoring Plan for the Hanford Groundwater Monitoring Project
}

\author{
M. J. Hartman \\ P. E. D resel \\ D. R. Newcomer \\ E. C. Thornton \\ J. W. Lindberg
}

October 2001

Prepared for the U.S. D epartment of Energy under Contract DE-AC06-76RL01830 


\section{DISCLAIMER}

This report was prepared as an account of work sponsored by an agency of the United States Government. Reference herein to any specific commercial product, process, or service by trade name, trademark, manufacturer, or otherwise does not necessarily constitute or imply its endorsement, recommendation, or favoring by the United States Government or any agency thereof, or Battelle Memorial Institute.

\section{PACIFIC NORTHWEST NATIONAL LABORATORY \\ operated by \\ BATTELLE \\ for the}

UNITED STATES DEPARTMENT OF ENERGY

under Contract DE-AC06-76RL01830

Printed in the United States of America

Available to DOE and DOE contractors from the

Office of Scientific and Technical Information, P.O. Box 62, Oak Ridge, TN 37831; prices available from (615) 576-8401.

Available to the public from the National Technical Information Service, U.S. Department of Commerce, 5285 Port Royal Rd., Springfield, VA 22161

This document was printed on recycled paper. 


\title{
FY 2002 Integrated Monitoring Plan for the Hanford Groundwater Monitoring Project
}

\author{
M. J. Hartman D. R. Newcomer \\ P. E. Dresel \\ E. C. Thornton \\ J. W. Lindberg
}

October 2001

Prepared for

the U.S. Department of Energy

under Contract DE-AC06-76RL01830

Pacific Northwest National Laboratory

Richland, Washington 99352 


\section{Summary}

Groundwater is monitored at the Hanford Site to fulfill a variety of state and federal regulations, including the Atomic Energy Act of 1954; the Resource Conservation and Recovery Act of 1976; the Comprehensive Environmental Response, Compensation, and Liability Act of 1980; and Washington Administrative Code. Separate monitoring plans are prepared for various requirements, but sampling is coordinated and data are shared among users to avoid duplication of effort. The U.S. Department of Energy manages these activities through the Hanford Groundwater Monitoring Project.

This document is an integrated monitoring plan for the groundwater project. It documents well and constituent lists for monitoring required by the Atomic Energy Act of 1954 and its implementing orders; includes other, established monitoring plans by reference; and appends a master well/constituent/ frequency matrix for the entire site.

The objectives of monitoring fall into three general categories: plume and trend tracking, treatment/ storage/disposal unit monitoring, and remediation performance monitoring. Criteria for selecting Atomic Energy Act of 1954 monitoring networks include locations of wells in relation to known plumes or contaminant sources, well depth and construction, historical data, proximity to the Columbia River, water supplies, or other areas of special interest and well use for other programs. Constituent lists were chosen based on known plumes and waste histories, historical groundwater data, and, in some cases, statistical modeling. Sampling frequencies were based on regulatory requirements, variability of historical data, and proximity to key areas. For sitewide plumes, most wells are sampled every 3 years. Wells monitoring specific waste sites or in areas of high variability will be sampled more frequently.

A total of 390 wells are scheduled to be sampled in fiscal year 2002 for surveillance monitoring. Approximately 330 of these well will be analyzed for nitrate, $\sim 280$ for tritium, and $\sim 100$ for iodine-129. Most of the wells are sampled annually, and $\sim 30$ more often than annually. Approximately 230 wells are sampled every two or three years for surveillance: 45 of these are scheduled for fiscal year 2002. A total of 736 wells are scheduled to be sampled in fiscal year 2002 for all programs combined. 


\section{Contents}

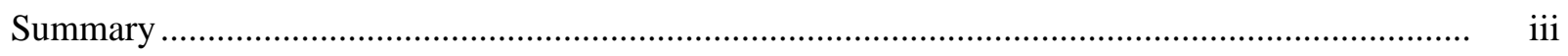

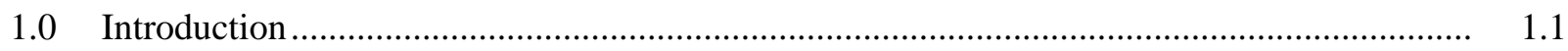

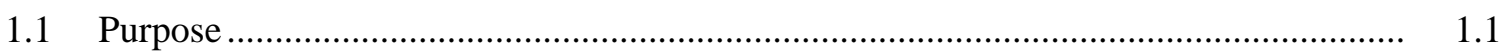

1.2 Objectives of Groundwater Monitoring ….......................................................... 1.1

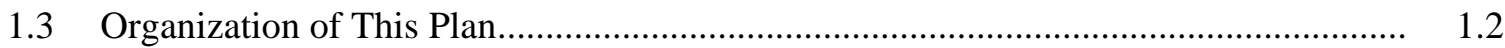

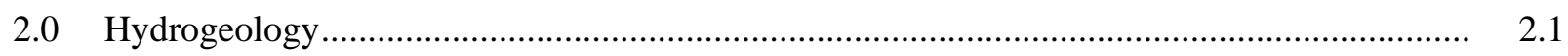

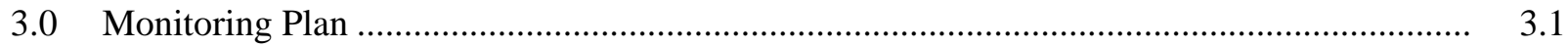

3.1 Groundwater Monitoring Network ................................................................. 3.1

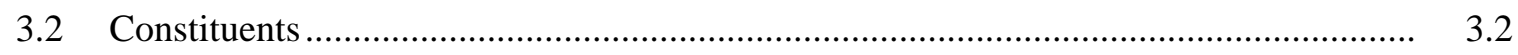

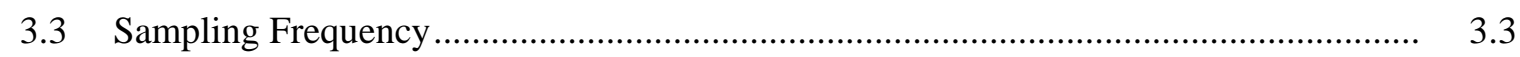

3.4 Changes to Monitoring Program ........................................................................ 3.3

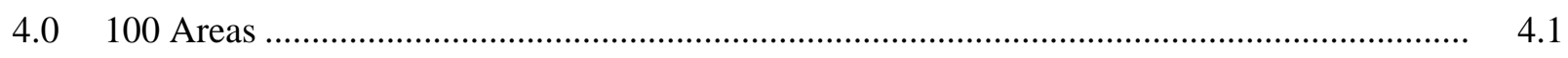

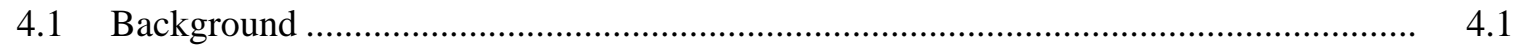

4.1.1 Waste Sites, Discharges, and Groundwater Operable Units ........................... 4.1

4.1.2 Groundwater Monitoring Requirements and History ................................... 4.1

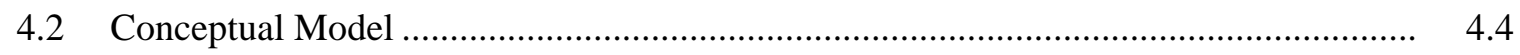

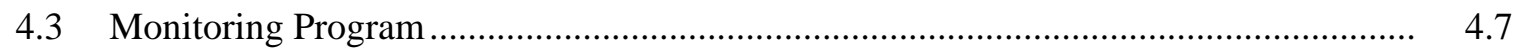

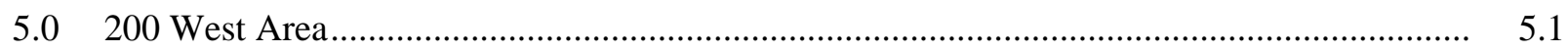

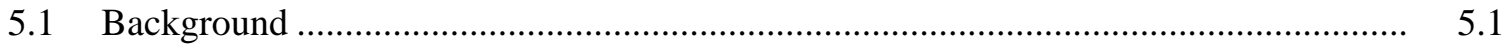

5.1.1 Waste Sites, Discharges, and Groundwater Operable Units .......................... 5.1

5.1.2 Groundwater Monitoring Requirements and History ................................... 5.1

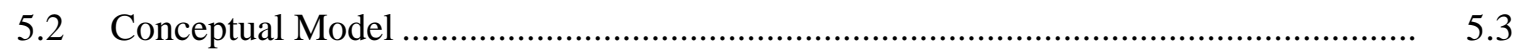

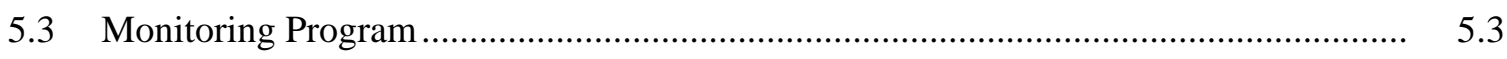




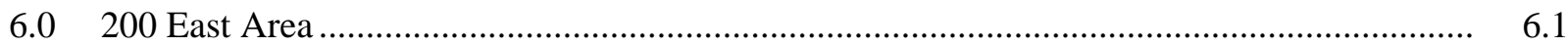

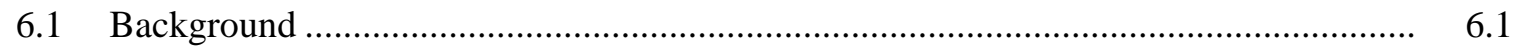

6.1.1 Waste Sites, Discharges, and Groundwater Operable Units .......................... 6.1

6.1.2 Groundwater Monitoring Requirements and History .................................... 6.3

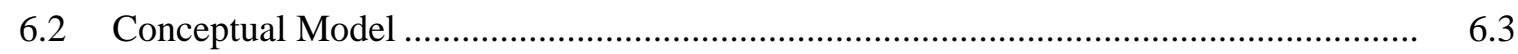

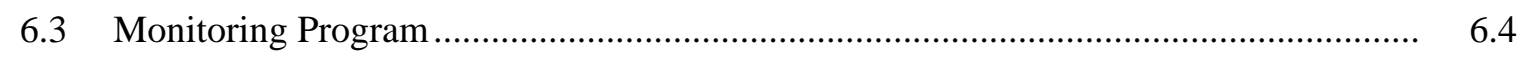

$7.0 \quad 400$ Area

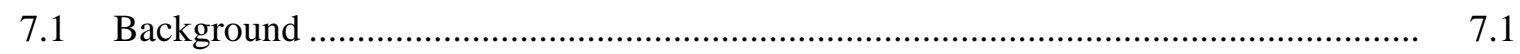

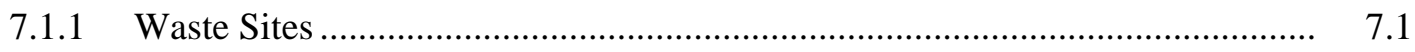

7.1.2 Groundwater Monitoring Requirements and History .................................. 7.1

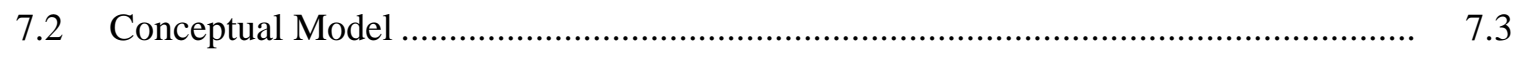

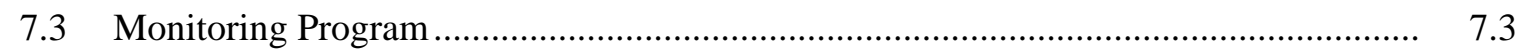

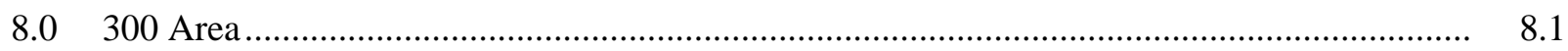

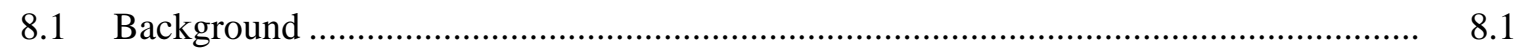

8.1.1 Waste Sites, Discharges, and Groundwater Operable Units .......................... 8.1

8.1.2 Groundwater Monitoring Requirements and History …............................... 8.2

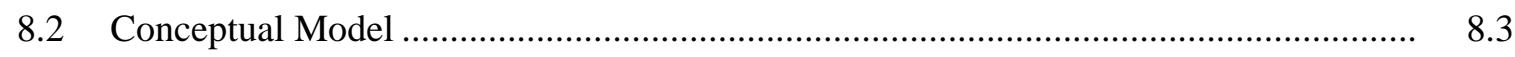

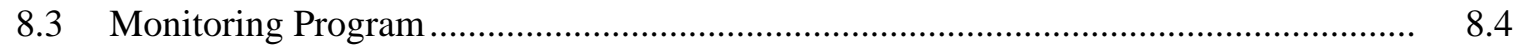

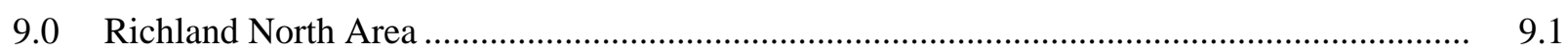

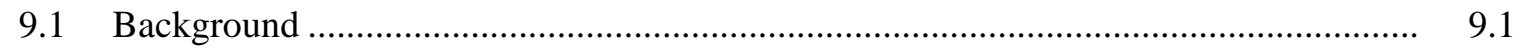

9.1.1 Waste Sites, Discharges, and Groundwater Operable Units ......................... 9.1

9.1 .2 Offsite Sources ........................................................................... 9.1

9.1.3 Groundwater Monitoring Requirements and History ................................ 9.2

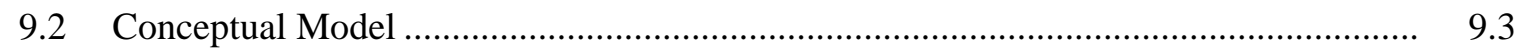

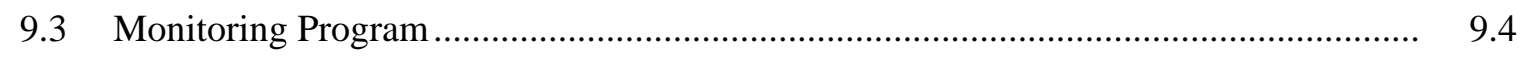


10.0600 Area, Offsite, and Confined Aquifer Monitoring Activities

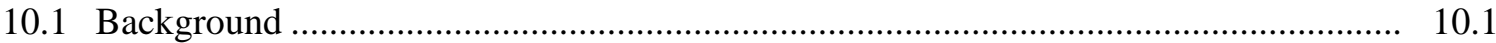

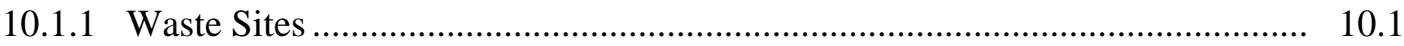

10.1.2 Groundwater Monitoring Requirements and History .................................. 10.1

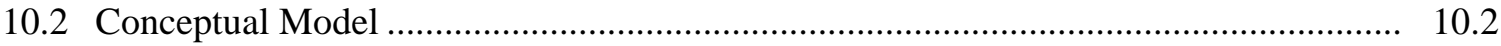

10.3 Monitoring Program ....................................................................................... 10.3

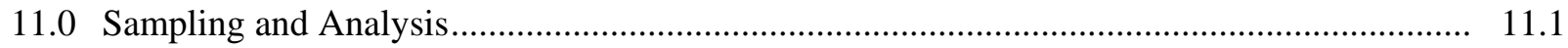

11.1 Sampling and Analysis Protocol ................................................................... 11.1

11.2 Quality Assurance and Quality Control ............................................................ 11.1

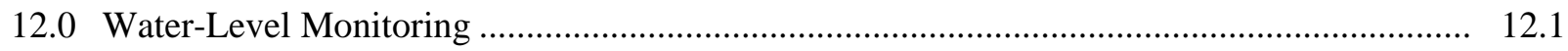

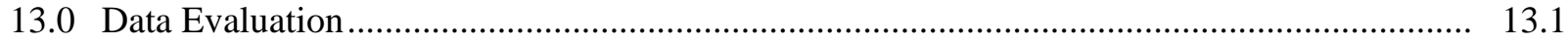

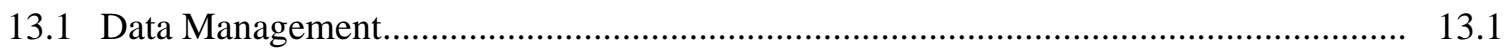

13.2 Compliance Issues and Data Evaluation …....................................................... 13.1

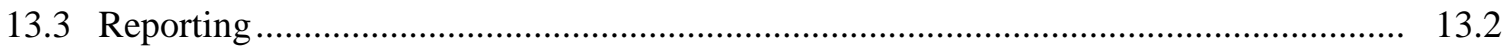

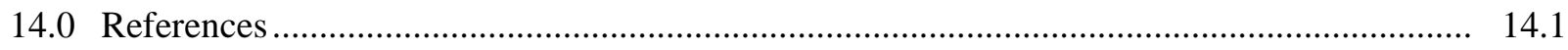

Appendix A - Sampling Matrix for Hanford Groundwater Monitoring ....................................... A.1 


\section{Figures}

2.1 Comparison of Generalized Hydrogeologic and Geologic Stratigraphy ............................. 2.2

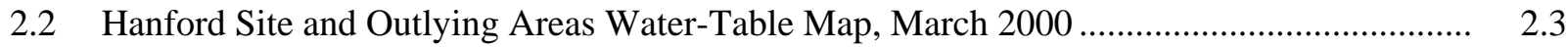

2.3 Distribution of Major Radionuclides in Groundwater at Concentrations Above Maximum Contaminant Levels or Interim Drinking Water Standards, Fiscal Year 2000 ....................... 2.4

2.4 Distribution of Major Hazardous Chemicals in Groundwater at Concentrations Above Maximum Contaminant Levels, Fiscal Year 2000........................................................ 2.5

4.1 Conceptual Model of Subsurface Contamination in the 100 Areas .................................... 4.6

4.2 Groundwater Project Well Locations: 100 B/C Area................................................... 4.8

4.3 Groundwater Project Well Locations: $100 \mathrm{~K}$ Area ...................................................... 4.9

4.4 Groundwater Project Well Locations: $100 \mathrm{~N}$ Area ….......................................................... 4.10

4.5 Groundwater Project Well Locations: 100 D Area ........................................................ 4.11

4.6 Groundwater Project Well Locations: $100 \mathrm{H}$ Area .............................................................. 4.12

4.7 Groundwater Project Well Locations: 100 F Area.......................................................

4.8 Groundwater Project Well Locations: 600 Area ......................................................... 4.15

5.1 Groundwater Project Well Locations: 200 West Area .................................................. 5.5

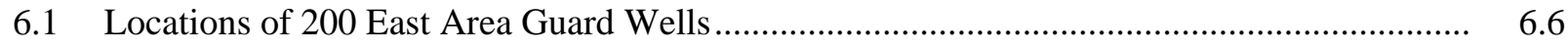

6.2 Groundwater Project Well Locations: 200 East Area ................................................. 6.9

7.1 Groundwater Project Well Locations: 400 Area ........................................................

8.1 Groundwater Project Well Locations: 300 and Richland North Areas .............................. 8.5

10.1 Groundwater Project Well Locations: Central Landfill ............................................. 10.4

10.2 Groundwater Project Well Locations: Basalt-Confined Aquifer .................................... 10.5 


\section{Tables}

1.1 Objectives of Groundwater Monitoring .................................................................. 1.2

4.1 Selected Waste Sites in the 100 Areas .......................................................................

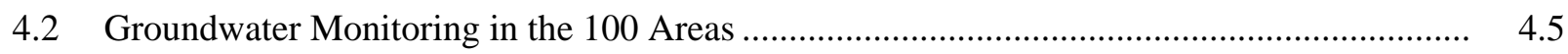

5.1 Selected Waste Sites in the 200 West Area................................................................. 5.2

6.1 Selected Waste Sites in and Downgradient of the 200 East Area ...................................... 6.2

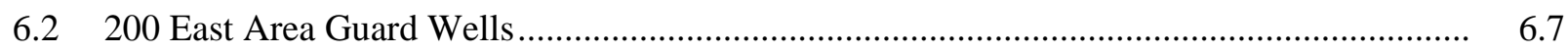

8.1 Selected Waste Sites in the 300 Area...................................................................... 8.2

9.1 Selected Waste Sites in the Richland North Area ....................................................... 9.2

10.1 Selected Waste Sites in the 600 Area........................................................................ 10.2

13.1 Compliance Issues and Methods of Evaluation ......................................................... 13.2 


\subsection{Introduction}

Groundwater is monitored in hundreds of wells at the Hanford Site to fulfill a variety of requirements. Separate monitoring plans are prepared for various requirements, but sampling is coordinated and data are shared among users to avoid duplication of effort. The U.S. Department of Energy (DOE) manages these activities through the Hanford Groundwater Monitoring Project ("groundwater project"), which is the responsibility of Pacific Northwest National Laboratory. The groundwater project does not include all of the monitoring to assess performance of groundwater remediation or all monitoring associated with active facilities.

This document is an integrated monitoring plan for the groundwater project and contains: well and constituent lists for monitoring required by the Atomic Energy Act of 1954 and its implementing orders ("surveillance monitoring"); other, established monitoring plans by reference; and a master well/ constituent/frequency matrix for the entire Hanford Site.

\subsection{Purpose}

The purpose of this plan is to integrate various requirements for groundwater monitoring on the Hanford Site. Specific objectives of this plan are the following:

- design and describe monitoring well networks, constituent lists, sampling frequency, and quality assurance/quality control for the surveillance monitoring network; explain criteria used to design the program

- encompass Resource Conservation and Recovery Act of 1976 (RCRA), Comprehensive Environmental Response, Compensation, and Liability Act of 1980 (CERCLA), Washington Administrative Code (WAC) regulations, and other monitoring plans by reference

- provide well, constituent, and sampling frequency lists for all groundwater monitoring on the site.

This plan is subordinate to the Environmental Monitoring Plan, U.S. Department of Energy, Richland Operations Office (DOE 2000), which is required by DOE Orders, and the Hanford Site Ground-Water Protection Management Plan (Barnett et al. 1995). This plan describes how DOE will implement the groundwater monitoring requirements described in those documents.

\subsection{Objectives of Groundwater Monitoring}

The environmental monitoring plan (DOE 2000) lists the purposes and objectives of groundwater monitoring and the groundwater project. These purposes and objectives fall into three general categories: 1) plume and trend tracking, 2) monitoring of treatment/storage/disposal units, and 3) independent assessment of performance monitoring for groundwater remediation activities (Table 1.1). 
Table 1.1. Objectives of Groundwater Monitoring

\begin{tabular}{||l||}
\hline \multicolumn{1}{||c||}{ Plume and Trend Tracking } \\
Determine baseline conditions of groundwater quality and quantity. \\
Characterize and define hydrogeologic, physical, and chemical trends in the groundwater system. \\
Identify existing and potential groundwater contamination sources. \\
Assess existing and emerging groundwater quality problems. \\
Evaluate existing and potential offsite impacts of groundwater contaminants. \\
Provide data on which decisions can be made concerning land-disposal practices and management and \\
protection of groundwater resources. \\
\hline \multicolumn{1}{c}{ Treatment/Storage/Disposal Unit Monitoring } \\
Demonstrate compliance with applicable regulations and orders (RCRA, WAC). \\
Provide data to permit early detection of groundwater pollution or contamination. \\
\hline \multicolumn{1}{c}{ Groundwater Remediation Performance Monitoring } \\
Provide continuing, independent assessment of groundwater remediation activities (groundwater remedi- \\
ation and performance monitoring are conducted by the environmental restoration contractor; currently, \\
Bechtel Hanford Inc.; groundwater project provides independent assessment).
\end{tabular}

Plume and trend tracking are the primary objectives of surveillance monitoring. Treatment/storage/ disposal unit monitoring includes units regulated under RCRA or state codes (recently active sites), CERCLA (past-practice sites), and the Atomic Energy Act of 1954. Monitoring associated with remediation activities is the responsibility of the environmental restoration contractor, but the groundwater project is responsible for "providing continuing, independent assessment of groundwater remediation activities" (DOE 2000).

\subsection{Organization of This Plan}

A brief overview of the hydrogeology of the Hanford Site is provided in Chapter 2 as background for the remainder of the plan. Chapter 3 describes the monitoring program, with an explanation of criteria for choosing well networks, constituent lists, and sampling frequency. Chapters 4 through 10 describe the waste sites, monitoring history, and a conceptual model of the movement of contaminants for each geographic region of the site. Chapter 11 describes the sampling and analysis plan, including methods for sampling and analysis, quality assurance, and quality control. Chapter 12 describes the water-levelmonitoring program; Chapter 13 describes data management, compliance issues, and reporting; followed by Chapter 14, the references cited herein.

An integrated monitoring matrix is presented in Appendix A, showing the wells to be sampled in fiscal year 2002. The appendix is updated annually. 


\subsection{Hydrogeology}

The hydrogeology of the Hanford Site has been described in many documents (e.g., Chapter 3 in Hartman 2000). A brief summary is provided here for the reader's convenience.

The uppermost aquifer beneath most of the Hanford Site is unconfined and composed of unconsolidated to semiconsolidated sands and gravels deposited on basalt bedrock. In some areas, deeper parts of the aquifer are locally confined by layers of silt and clay. Confined aquifers occur within the underlying basalt flows and associated sedimentary interbeds. A simplified stratigraphic column is illustrated in Figure 2.1.

Groundwater in the unconfined aquifer system generally moves from recharge areas along the western boundary of the site to the east and north toward the Columbia River, which is the major discharge area. This natural flow pattern was altered by the formation of groundwater mounds created by large volumes of artificial recharge at wastewater-disposal facilities. These mounds are declining, and groundwater flow is gradually returning to earlier patterns. Figure 2.2 shows a water-table map for March 2000.

The extent of major radionuclide contaminants in groundwater in fiscal year 2000 is illustrated in Figure 2.3. Iodine-129, strontium-90, technetium-99, tritium, and uranium were present at levels above drinking water standards. Carbon-14, cesium-137, and plutonium exceeded standards in smaller areas. The extent of major hazardous chemical constituents in fiscal year 2000 is shown in Figure 2.4. The most significant of these include carbon tetrachloride, chromium, and nitrate. Arsenic, fluoride, and trichloroethene are also elevated in smaller areas. 


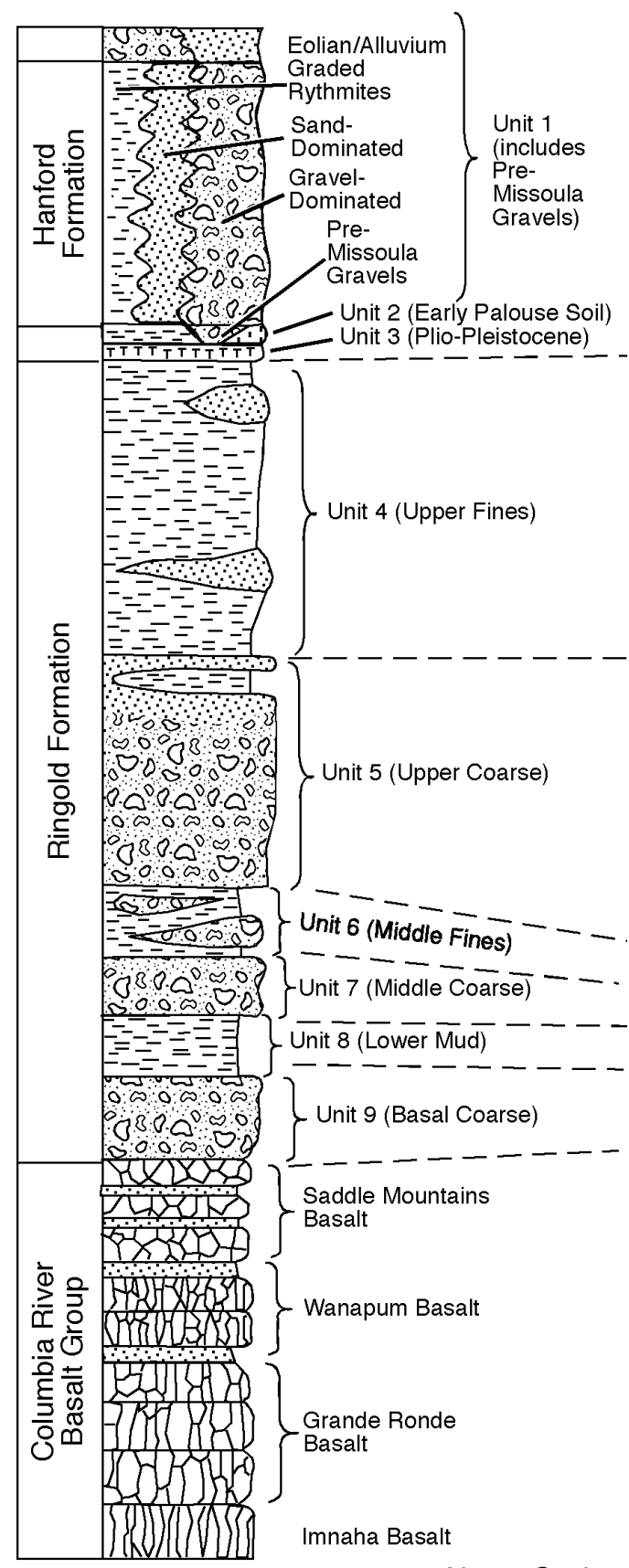

From PNL-8971
Not to Scale

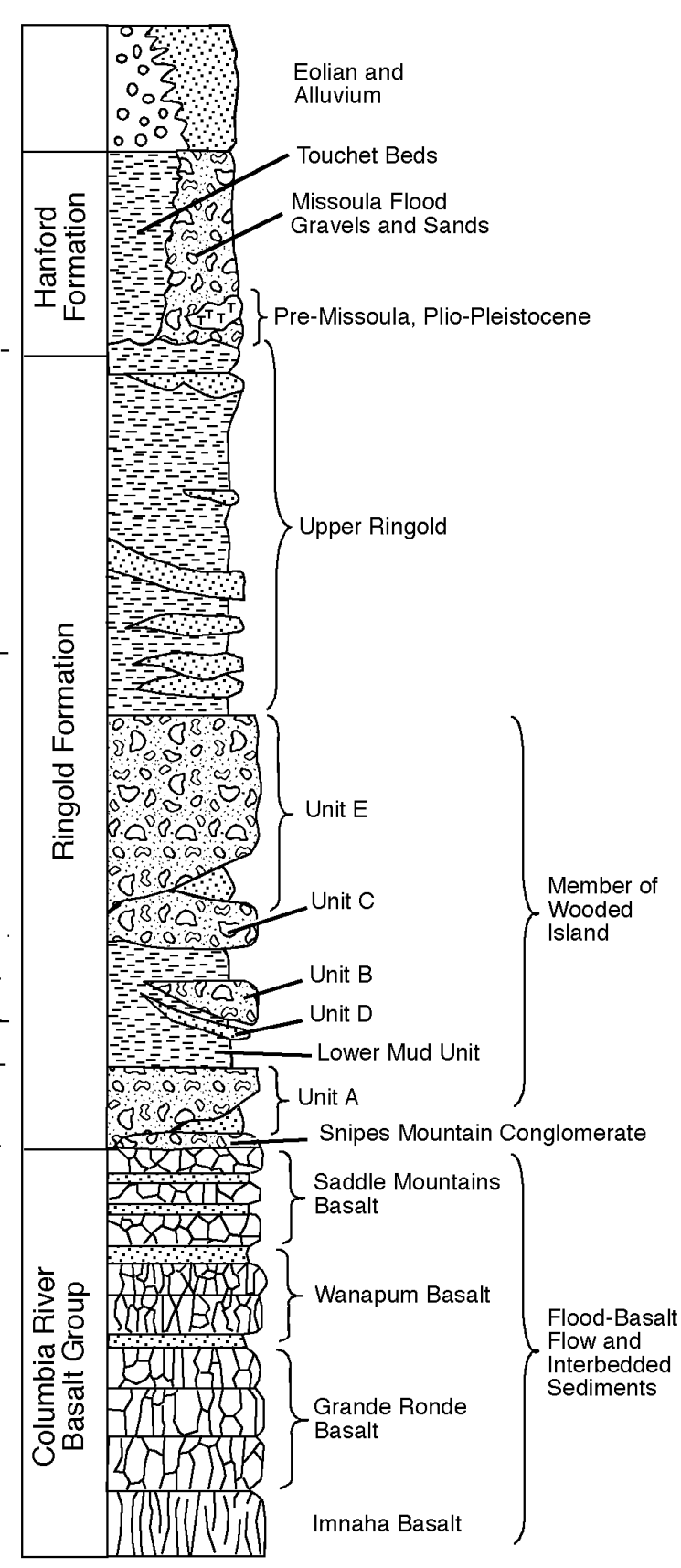

After BHI-00184

RG98120214.14

Figure 2.1. Comparison of Generalized Hydrogeologic and Geologic Stratigraphy 


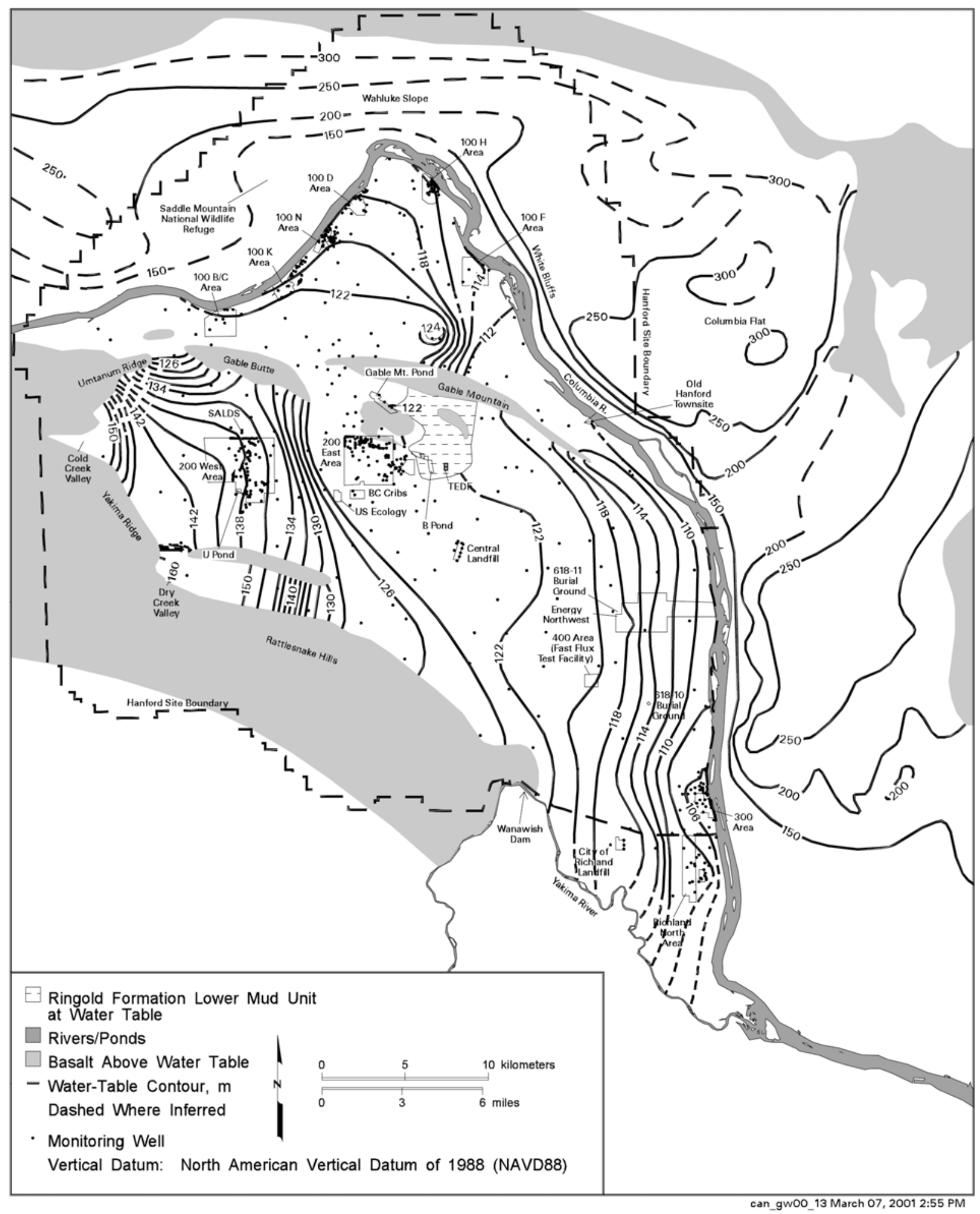

Figure 2.2. Hanford Site and Outlying Areas Water-Table Map, March 2000 (from Hartman et al. 2001) 


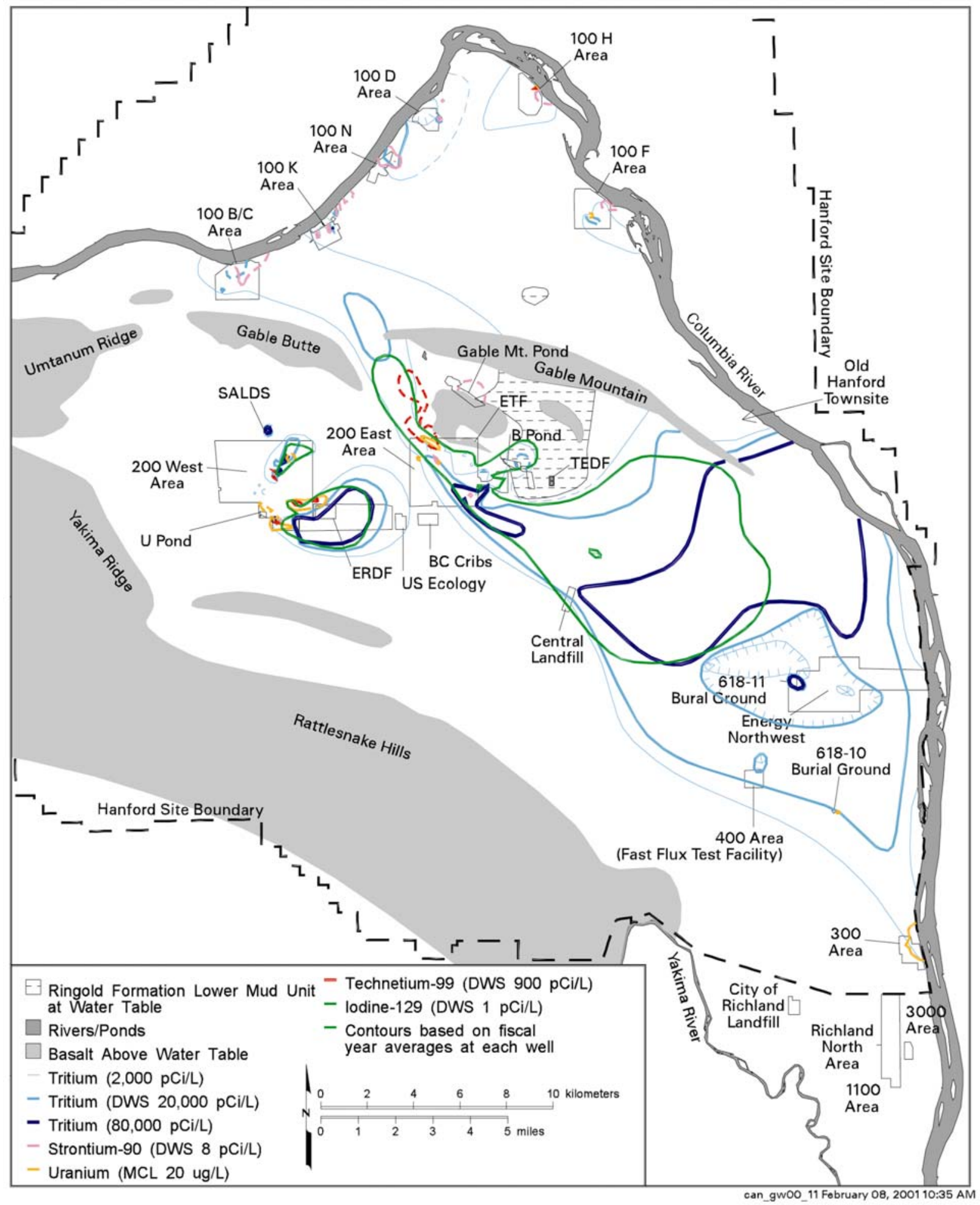

Figure 2.3. Distribution of Major Radionuclides in Groundwater at Concentrations Above Maximum Contaminant Levels (MCLs) or Interim Drinking Water Standards (DWSs), Fiscal Year 2000 (Hartman et al. 2001) 


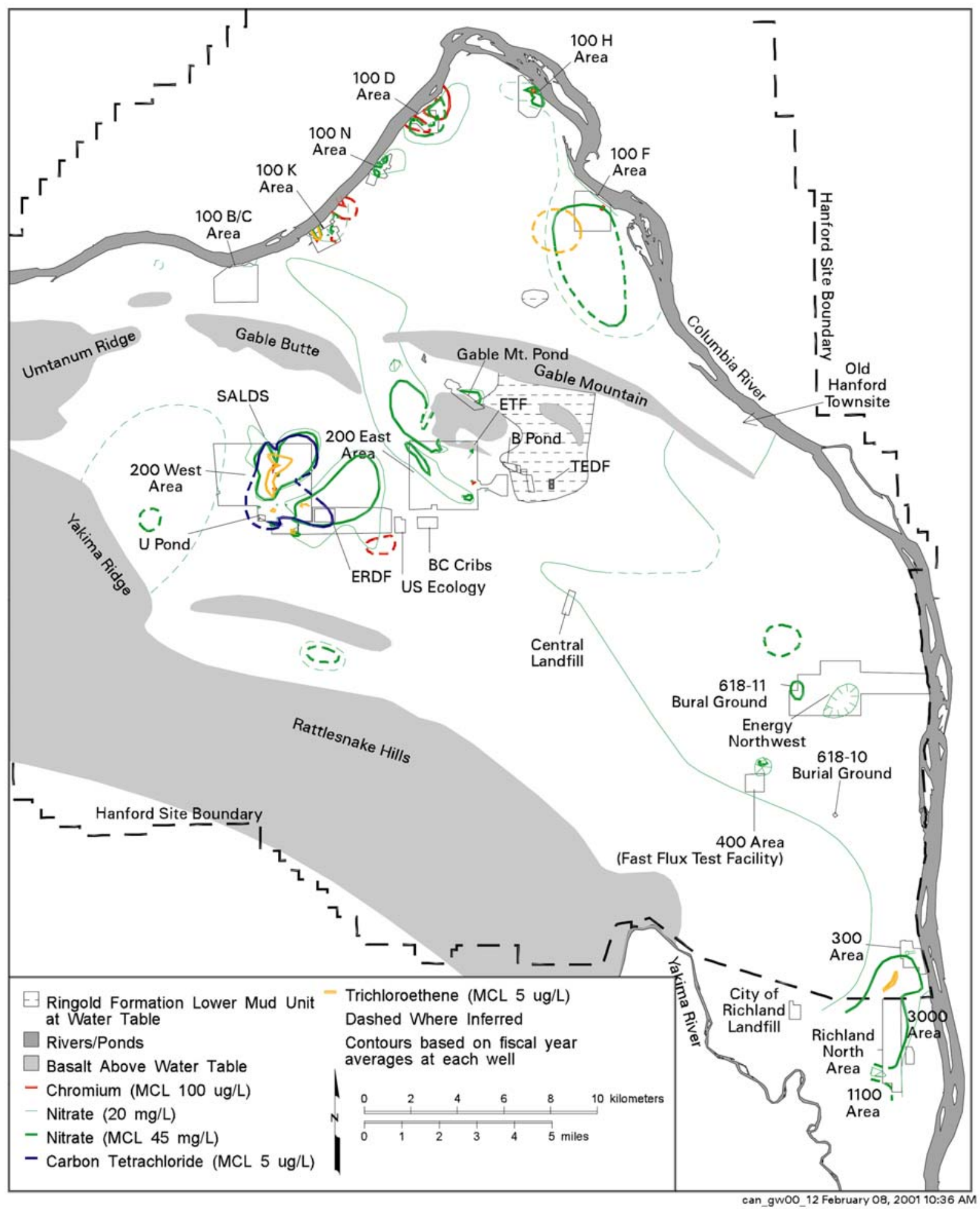

Figure 2.4. Distribution of Major Hazardous Chemicals in Groundwater at Concentrations Above Maximum Contaminant Levels (MCLs), Fiscal Year 2000 (Hartman et al. 2001) 


\subsection{Monitoring Program}

The integrated sampling and analysis matrix for the groundwater project is given in Appendix A. The matrix was designed for use in fiscal year 2002, but also includes wells that will be sampled every 2 or 3 years, as discussed in Section 3.3. The matrix includes well name, program, project, sampling frequency, and constituents to be monitored. Additional details, such as schedule, analytical methods, etc., reside in a project database.

\subsection{Groundwater Monitoring Network}

Wells on the Hanford Site are monitored in compliance with: 1) the Atomic Energy Act 1954 and its implementing orders ("surveillance monitoring"), 2) CERCLA operable units, 3) remedial action performance assessment, 4) RCRA, and 5) WAC permits. Monitoring networks for items 2 through 5 are defined in monitoring plans, interim records of decision, permits or change agreements listed in Chapters 4 through 10. These monitoring networks are included in the monitoring matrix of Appendix A. The criteria for choosing wells for surveillance monitoring are discussed below.

1. Defining plumes - A representative areal distribution of wells within the plume is monitored, with an emphasis on wells with the highest concentrations of contaminants and wells near plume boundaries. Some wells in uncontaminated areas between plumes are also monitored to help control interpretation of plume boundaries and to monitor plume migration. Plumes migrating onto the site from offsite sources are also monitored (e.g., agricultural effects, Richland Landfill, Framatome ANP [formerly Siemens Power Corporation]). A geostatistical approach was employed to determine which wells should be sampled to track major plumes from the 200 West and 200 East Areas (discussed in Chapters 5 and 6).

2. Monitoring contaminant sources - Waste-disposal facilities not regulated by RCRA or the WAC are included in surveillance monitoring (e.g., $100 \mathrm{~K}$ basins, 216-U-1 crib). Wells downgradient of these facilities are monitored to detect their impact on groundwater.

3. Interval monitored - Most of the groundwater contamination on the Hanford Site is contained in the uppermost (unconfined) aquifer, so most of the monitoring wells are screened there. Newer wells installed for RCRA and CERCLA are screened across the water table and monitor the top 3 to 10 meters of the unconfined aquifer. Wells that monitor a longer interval are less desirable because contaminants could be diluted from representative concentrations to below detection limits. A few wells monitor deeper intervals of the suprabasalt sediments or confined aquifers in the basalt. These wells are sampled to monitor whether contamination has migrated deeper in the hydrologic system.

4. Historical data - Previous groundwater chemistry or water-level data in a well are useful for monitoring trends and for determining sampling frequency and constituent lists. Wells with historical data are preferable to those without. 
5. Adequacy of well construction - Wells with poor seals, broken casing, or other problems may not provide representative data, and will be remediated or decommissioned.

6. Amount of water in the well - Declining water levels are causing some wells to go dry. Wells that are likely to contain sufficient water for sampling are chosen for the network.

7. Proximity to the Columbia River - In some cases, it is desirable to monitor wells very near the river shore to assess what concentrations of contaminants are entering the river. In other cases, it is more advantageous to choose wells farther inland to avoid fluctuations in concentration caused by bank storage effects.

8. Use by other requirements of the groundwater project (e.g., RCRA, CERCLA) - Wells being sampled for other purposes are used for surveillance monitoring, where possible, for a more costeffective program.

9. "Guard wells" - Key areas have been identified as being of special interest: bands of wells in Gable Gap and southeast of the 200 East Area were chosen to monitor contamination migrating out of the 200 Areas (discussed in Chapter 6), wells near the Columbia River, wells in the southern portion of the site near the city of Richland's North Well Field and recharge basins.

10. Performance assessment - The environmental restoration contractor (i.e., Bechtel Hanford, Inc.) conducts performance assessment monitoring in conjunction with remedial actions. The groundwater project is responsible for providing independent assessment of remedial actions, so wells near the remedial actions are included.

\subsection{Constituents}

Constituents are included in the sampling matrix of Appendix A. This matrix is an abbreviated version of the sampling matrix maintained by the groundwater project, which specifies various methods of analysis for some constituents.

The following criteria were considered to determine what analyses should be run on the samples for surveillance monitoring:

1. Proximity to known plumes or waste sites - If a well is located in a contaminant plume or downgradient of a plume, it is generally sampled for that contaminant.

2. Historical data in well - Wells are generally not sampled for constituents that have not been detected or are below some level of interest (e.g., drinking water standards) unless they are monitoring movement of a nearby plume.

3. Statistical modeling (discussed in Chapter 6). 
4. Use for other requirements - If there is a choice of analytical method for a desired constituent, the method used for other monitoring purposes is chosen if it is satisfactory for surveillance monitoring.

5. State of Washington Department of Health constituents - Constituents, including total alpha, anions, total beta, gamma, iodine-129, technetium-99, tritium, and uranium isotopes, are co-sampled to provide a quality control check.

The choice of constituents for RCRA, CERCLA, and other monitoring requirements are based on waste history, permit conditions, and constituents of concern, as discussed in their monitoring plans.

\subsection{Sampling Frequency}

Sampling frequency for RCRA, CERCLA, and other monitoring requirements are determined by regulation, permits, or other agreements. Frequency for plume and trend tracking are based on the following criteria:

1. Variability of historical data - If previous concentrations are level or are on a steady trend, lessfrequent sampling (every 3 years) is sufficient. Wells with larger variability are sampled more frequently (annually or more often).

2. Proximity to key areas — Guard wells (see Section 3.1) and wells monitoring source areas are sampled more frequently.

3. Mobility of contaminants in groundwater - Contaminants with greater mobility (e.g., tritium) may be sampled more frequently than those that are not very mobile in groundwater (e.g., strontium-90).

\subsection{Changes to Monitoring Program}

As data are received and evaluated, changes will be made to the program, as needed. For example, if the concentration of a contaminant in a well increases suddenly, an additional sample may be collected and analyzed to confirm or refute the initial result. This type of "one-time" change may be made without revision of this plan.

Each year the well/constituent matrix in this plan will be reviewed for adequacy and revised for the following fiscal year. These revisions will incorporate any changes made to monitoring plans for RCRA, CERCLA, and other requirements. 


\subsection{Areas}

For the purposes of this plan, "100 Areas" describes that portion of the Hanford Site north of Gable Mountain and Gable Butte and south of the Columbia River and includes the six reactor areas (B/C, K, N, $\mathrm{D}, \mathrm{H}$, and $\mathrm{F}$ [upstream to downstream]) and the 600 Area in between.

\subsection{Background}

Hundreds of waste sites have been identified in the 100 Areas, including fuel storage or retention basins that leaked; effluent disposal cribs, ditches, and drains; and various spills or other unplanned releases. Those with site-specific monitoring requirements and those that appear to have affected groundwater quality are listed in Table 4.1.

\subsubsection{Waste Sites, Discharges, and Groundwater Operable Units}

Inactive radiological or mixed waste sites in the 100 Areas are being cleaned up or monitored under the requirements of CERCLA or as RCRA past-practice sites. Four sites are regulated under RCRA because they were more recently active and contained dangerous waste constituents. Another RCRA site, 120-D-1 ponds, was "clean-closed," and no longer requires monitoring. Two sites currently discharge nondangerous effluent to the ground (sanitary waste and filter backwash in the $100 \mathrm{~N}$ Area).

Groundwater beneath the reactor areas and surrounding areas is divided into five groundwater operable units: 100-BC-5 (100 B/C Area), 100-KR-4 (100 K Area), 100-NR-2 (100 N Area), 100-HR-3 (100 D and $100 \mathrm{H}$ Area), and 100-FR-3 (100 F Area). Pump-and-treat systems are active in the $100 \mathrm{~K}$, $100 \mathrm{D}$, and $100 \mathrm{H}$ Areas for chromium and in the $100 \mathrm{~N}$ Area for strontium-90. An in situ treatment system is active in the $100 \mathrm{D}$ Area to chemically reduce hexavalent chromium to insoluble chromium compounds (redox manipulation). All of these remediation systems are considered interim actions; final remedial actions have not yet been selected.

\subsubsection{Groundwater Monitoring Requirements and History}

Limited groundwater monitoring has been conducted in the reactor areas since the 1940s. Very few monitoring wells existed in the early decades but more were installed in the $100 \mathrm{~K}, 100 \mathrm{~N}$, and $100 \mathrm{H}$ Areas in the 1970s and monitored for DOE requirements. RCRA monitoring began in the late 1980 s in the $100 \mathrm{~N}$ and $100 \mathrm{H}$ Areas, and in the early 1990s in the $100 \mathrm{D}$ Area, so additional wells were installed. CERCLA investigations and cleanup actions in the 1990s resulted in the installation of dozens more wells, spread among the reactor areas and the intervening 600 Area between the $100 \mathrm{D}$ and $100 \mathrm{H}$ Areas.

CERCLA interim actions in the $100 \mathrm{~K}, 100 \mathrm{~N}, 100 \mathrm{D}$, and $100 \mathrm{H}$ Areas include specific monitoring requirements. CERCLA operable unit monitoring networks have also been defined for these areas and for 
Table 4.1. Selected Waste Sites in the 100 Areas $^{(a)}$

\begin{tabular}{|c|c|c|c|}
\hline Facility (period of use) & Waste Type & $\begin{array}{l}\text { Constituents of Interest } \\
\text { for Groundwater } \\
\text { Monitoring }\end{array}$ & Status \\
\hline \multicolumn{4}{|c|}{$100 \mathrm{~B} / \mathrm{C}$ Area } \\
\hline $\begin{array}{l}\text { 116-B-11 (1944-1968) and } \\
116-C-5(1952-1969) \\
\text { retention basins }\end{array}$ & $\begin{array}{l}\text { Reactor coolant effluent; leaks } \\
\text { known }\end{array}$ & $\begin{array}{l}\text { Radionuclides, metals } \\
\text { strontium-90, chromium }\end{array}$ & $\begin{array}{l}\text { Past-practice; } \\
\text { contaminated soil } \\
\text { removed; backfilled }\end{array}$ \\
\hline $\begin{array}{l}116-B-1(1950-1968) \text { and } \\
116-C-1(1952-1968) \\
\text { waste-disposal trenches }\end{array}$ & $\begin{array}{l}\text { Coolant effluent from fuel- } \\
\text { element failure (highly } \\
\text { radioactive) }\end{array}$ & Radionuclides & $\begin{array}{l}\text { Past-practice; } \\
\text { contaminated soil } \\
\text { removed }\end{array}$ \\
\hline 116-B-5 crib (1950-1968) & Process effluent & Tritium & $\begin{array}{l}\text { Past-practice; } \\
\text { contaminated soil } \\
\text { removed }\end{array}$ \\
\hline $\begin{array}{l}\text { 118-B-6 burial ground } \\
(1950-1953)\end{array}$ & Contaminated equipment & High-level tritium & Past-practice \\
\hline $\begin{array}{l}\text { Storage tanks and transfer } \\
\text { facilities (1944-1969) }\end{array}$ & $\begin{array}{l}\text { Sodium dichromate leakage } \\
\text { from water-treatment facilities }\end{array}$ & Chromium & Past-practice \\
\hline \multicolumn{4}{|c|}{$100 \mathrm{~K}$ Area } \\
\hline $\begin{array}{l}\text { Reactor buildings fuel- } \\
\text { storage basins (KE: 1955- } \\
\text { 1971; 1975-present. KW: } \\
\text { 1955-1971; 1981-present) }\end{array}$ & $\begin{array}{l}\text { Radionuclide-contaminated } \\
\text { water; leaks known }\end{array}$ & Tritium, strontium-90 & Active \\
\hline $\begin{array}{l}\text { 116-KE-3 (1955-1971) and } \\
116-K W-2(1955-1970) \\
\text { french drain/reverse well }\end{array}$ & $\begin{array}{l}\text { Effluent from fuel-storage } \\
\text { basin drainage collection }\end{array}$ & Tritium, strontium-90 & Past-practice \\
\hline $\begin{array}{l}\text { 116-KE-1 (1955-1971) and } \\
\text { 116-KW-1 (1955-1971) } \\
\text { cribs }\end{array}$ & Reactor condensate & Tritium, carbon-14 & Past-practice \\
\hline $\begin{array}{l}\text { 116-K-2 trench (1955- } \\
1971)\end{array}$ & $\begin{array}{l}\text { Reactor coolant water, } \\
\text { decontamination liquids }\end{array}$ & Chromium, strontium-90 & Past-practice \\
\hline $\begin{array}{l}116-K W-3(1954-1970) \\
\text { and 116-KE-4 (1955-1971) } \\
\text { retention basins }\end{array}$ & Reactor coolant; leaks known & Radionuclides & Past-practice \\
\hline $\begin{array}{l}\text { Storage tanks and transfer } \\
\text { facilities }\end{array}$ & $\begin{array}{l}\text { Sodium dichromate leakage } \\
\text { from } 183-\mathrm{KE} \text { and } 183-\mathrm{KW} \\
\text { water-treatment facilities }\end{array}$ & Chromium & Past-practice \\
\hline \multicolumn{4}{|c|}{100 N Area } \\
\hline $\begin{array}{l}\text { 1301-N liquid waste- } \\
\text { disposal facility (1963- } \\
\text { 1985) }\end{array}$ & Reactor coolant & $\begin{array}{l}\text { Strontium-90, tritium, } \\
\text { minor hazardous } \\
\text { constituents }^{(\mathrm{b})}\end{array}$ & RCRA past-practice \\
\hline $\begin{array}{l}\text { 1325-N liquid waste- } \\
\text { disposal facility (1983- } \\
\text { 1989) }\end{array}$ & Reactor coolant & $\begin{array}{l}\text { Strontium-90, tritium, } \\
\text { minor hazardous } \\
\text { constituents }^{(\mathrm{b})}\end{array}$ & $\begin{array}{l}\text { RCRA past-practice; } \\
\text { excavation in progress }\end{array}$ \\
\hline
\end{tabular}


Table 4.1. (contd)

\begin{tabular}{|c|c|c|c|}
\hline Facility (period of use) & Waste Type & $\begin{array}{l}\text { Constituents of Interest } \\
\text { for Groundwater } \\
\text { Monitoring }\end{array}$ & Status \\
\hline $\begin{array}{l}\text { 1324-NA percolation pond } \\
(1986-1990)\end{array}$ & Treated demineralizer effluent & Sulfate, sodium, $\mathrm{pH}^{(\mathrm{b})}$ & RCRA past-practice \\
\hline Fuel station & Fuel tank leaks confirmed & Hydrocarbons & Past-practice \\
\hline N Reactor basins & Fuel-storage basins & Radionuclides & Inactive \\
\hline $\begin{array}{l}\text { 183-N backwash discharge } \\
\text { pond (1983-present) }\end{array}$ & Filter backwash & None & Active \\
\hline $\begin{array}{l}\text { 124-N-10 sewage lagoon } \\
\text { (1987-present) }\end{array}$ & Sanitary waste & Nitrate, coliform & $\begin{array}{l}\text { Active; WAC } \\
\text { permitted }\end{array}$ \\
\hline \multicolumn{4}{|c|}{100 D Area } \\
\hline $\begin{array}{l}\text { 116-D-7 (1944-1967) and } \\
\text { 116-DR-9 (1950-1967) } \\
\text { retention basins }\end{array}$ & Reactor coolant; leaks known & Radionuclides, chromium & $\begin{array}{l}\text { Past-practice; removed } \\
\text { and backfilled }\end{array}$ \\
\hline $\begin{array}{l}\text { 116-D-1 }(1947-1967) \text { and } \\
\text { 116-DR-2 (1950-1967) } \\
\text { trenches }\end{array}$ & $\begin{array}{l}\text { Highly radioactive coolant } \\
\text { from fuel-element failure }\end{array}$ & Radionuclides & $\begin{array}{l}\text { Past-practice; removed } \\
\text { and backfilled }\end{array}$ \\
\hline Reactor cribs, drains & $\begin{array}{l}\text { Water and sludges from fuel- } \\
\text { storage basins; decontamina- } \\
\text { tion solutions; condensate } \\
\text { from inert gas system }\end{array}$ & $\begin{array}{l}\text { Carbon-14, nitrate, } \\
\text { strontium- } 90\end{array}$ & $\begin{array}{l}\text { Past-practice; } \\
\text { contaminated soil } \\
\text { removed }\end{array}$ \\
\hline $\begin{array}{l}\text { Storage tanks and transfer } \\
\text { facilities }\end{array}$ & $\begin{array}{l}\text { Sodium dichromate leakage } \\
\text { from corrosion inhibitor }\end{array}$ & Chromium & Past-practice \\
\hline $\begin{array}{l}\text { 120-D-1 ponds (1977- } \\
\text { 1994) }\end{array}$ & Effluent from water treatment & $\mathrm{pH}$, mercury $^{(\mathrm{b})}$ & $\begin{array}{l}\text { Contaminated soil } \\
\text { removed; RCRA clean } \\
\text { closed }^{(\mathbf{c})}\end{array}$ \\
\hline \multicolumn{4}{|c|}{100 H Area } \\
\hline $\begin{array}{l}\text { 116-H-7 (107-H) retention } \\
\text { basin }(1949-1965)\end{array}$ & Reactor coolant; leaks known & Tritium, strontium-90 & $\begin{array}{l}\text { Past-practice; } \\
\text { contaminated soil } \\
\text { removed }\end{array}$ \\
\hline $\begin{array}{l}\text { 116-H-1 (107-H) trench } \\
(1952-1965)\end{array}$ & $\begin{array}{l}\text { Highly radioactive coolant } \\
\text { from reactor fuel-element } \\
\text { failure }\end{array}$ & $\begin{array}{l}\text { Tritium, strontium-90, } \\
\text { nitrate }\end{array}$ & $\begin{array}{l}\text { Past-practice; } \\
\text { contaminated soil } \\
\text { removed }\end{array}$ \\
\hline Reactor cribs, drains & $\begin{array}{l}\text { Water and sludge from fuel- } \\
\text { storage basins; decontamina- } \\
\text { tion solutions }\end{array}$ & Chromium & Past-practice \\
\hline $\begin{array}{l}\text { 183-H solar evaporation } \\
\text { basins (1973-1985) }\end{array}$ & Neutralized acid etch solutions & $\begin{array}{l}\text { Technetium-99, uranium, } \\
\text { nitrate, chromium, } \\
\text { fluoride }\end{array}$ & $\begin{array}{l}\mathrm{RCRA}^{(\mathrm{d})} ; \text { removed and } \\
\text { backfilled }\end{array}$ \\
\hline
\end{tabular}


Table 4.1. (contd)

\begin{tabular}{|c|c|c|c|}
\hline Facility (period of use) & Waste Type & $\begin{array}{c}\text { Constituents of Interest } \\
\text { for Groundwater } \\
\text { Monitoring } \\
\end{array}$ & Status \\
\hline \multicolumn{4}{|c|}{100 F Area } \\
\hline $\begin{array}{l}\text { 116-F-14 retention basin } \\
\text { and pipelines }(1945-1965)\end{array}$ & Reactor coolant; leaks known & Strontium-90, chromium & $\begin{array}{l}\text { Past-practice; } \\
\text { excavated }\end{array}$ \\
\hline $\begin{array}{l}\text { 116-F-2 trench }(1950- \\
1965)\end{array}$ & Highly radioactive coolant & Strontium-90, chromium & Past-practice \\
\hline $\begin{array}{l}\text { 116-F-9 trench (1963- } \\
\text { 1976) }\end{array}$ & $\begin{array}{l}\text { Cleaning waste from } \\
\text { experimental animal } \\
\text { laboratories }\end{array}$ & Radionuclides & Past-practice \\
\hline $\begin{array}{l}116-F-3(1947-1951) \text { and } \\
116-F-6(1952-1965) \\
\text { trenches }\end{array}$ & Reactor coolant and sludge & Radionuclides & Past-practice; \\
\hline $\begin{array}{l}\text { 116-F-1 trench }(1953- \\
1965)\end{array}$ & $\begin{array}{l}\text { Liquid waste from reactor and } \\
\text { associated buildings }\end{array}$ & $\begin{array}{l}\text { Radionuclides, metals, } \\
\text { uranium, strontium-90, } \\
\text { nitrate }\end{array}$ & Past-practice \\
\hline $\begin{array}{l}\text { 118-F-1 (1954-1965) and } \\
118-F-6(1965-1973) \text { solid } \\
\text { waste-burial grounds }\end{array}$ & $\begin{array}{l}\text { Contaminated equipment, } \\
\text { animal waste, coal ash }\end{array}$ & Tritium, plutonium & Past-practice \\
\hline $\begin{array}{l}\text { (a) Sites with specific grou } \\
\text { quality. } \\
\text { (b) Known or suspected in } \\
\text { (c) Clean closed in } 1999 \text { (n } \\
\text { (d) Groundwater beneath } 1\end{array}$ & $\begin{array}{l}\text { dwater monitoring requirements } \\
\text { vaste; not significantly detected it } \\
\text { waste left in place). No further } \\
3-\mathrm{H} \text { to be remediated under CER }\end{array}$ & $\begin{array}{l}\text { nd those that appear to hav } \\
\text { groundwater to date. } \\
\text { CRA monitoring required. } \\
\text { LA. }\end{array}$ & Iffected groundwater \\
\hline
\end{tabular}

the $100 \mathrm{~B} / \mathrm{C}$ and $100 \mathrm{~F}$ Areas. The $\mathrm{K}$ Basins, where spent reactor fuel rods are stored, have leaked in the past and are monitored under DOE Order 5400.1. Monitoring plans for the K Basins, CERCLA, and RCRA are referenced in Table 4.2.

The Atomic Energy Act of 1954 and DOE Order 5400.1 also require sitewide surveillance monitoring to track contaminant plumes. This document serves as the monitoring plan for surveillance monitoring performed per DOE orders.

\subsection{Conceptual Model}

The most widespread contaminants of concern in 100 Areas' groundwater are hexavalent chromium, nitrate, and tritium. Groundwater is locally contaminated with carbon-14, strontium-90, sulfate, technetium-99, trichloroethene, and uranium. Groundwater also flows into the 100 Areas through the gap between Gable Mountain and Gable Butte, carrying contamination from the 200 Areas. 
Table 4.2. Groundwater Monitoring in the 100 Areas

\begin{tabular}{|c|c|}
\hline $\begin{array}{l}\text { Monitoring Requirement } \\
\text { (monitoring plan reference) }\end{array}$ & Comments \\
\hline \multicolumn{2}{|c|}{$100 \mathrm{~B} / \mathrm{C}$ Area } \\
\hline $\begin{array}{l}\text { CERCLA (Federal Facility Agreement and } \\
\text { Consent Order Change Control Form M-15-99-03; } \\
\text { Sweeney 2000a) }\end{array}$ & Long-term plume monitoring \\
\hline \multicolumn{2}{|c|}{100 K Area } \\
\hline CERLCA (ROD 1996a; DOE 1997a) & $\begin{array}{l}\text { CERCLA interim action for chromium; wells near } \\
116-\mathrm{K}-2 \text { trench }^{(\mathrm{a})}\end{array}$ \\
\hline $\begin{array}{l}\text { CERCLA (National Priorities List Change Control } \\
\text { Form } 108 \text {, November } 20,1996 \text { ) }\end{array}$ & 100-KR-4 Operable Unit remedial investigation \\
\hline DOE Order 5400.1 (Johnson et al. 1995) & $\mathrm{KE}$ and KW fuel storage basins \\
\hline \multicolumn{2}{|c|}{$100 \mathrm{~N}$ Area } \\
\hline RCRA (Hartman 1996) & 1301-N, 1324-N/NA, 1325-N sites \\
\hline $\begin{array}{l}\text { CERCLA (National Priorities List Change Control } \\
\text { Form 113, March 25, 1997; DOE 2001) }\end{array}$ & $\begin{array}{l}\mathrm{N} \text { springs expedited response action (strontium-90 plume } \\
\text { near } 1301-\mathrm{N})^{(\mathrm{a})}\end{array}$ \\
\hline $\begin{array}{l}\text { CERCLA (Federal Facility Agreement and } \\
\text { Consent Order Change Control Form M-15-96-08, } \\
\text { October 9, 1996; Borghese et al. 1996) }\end{array}$ & $\begin{array}{l}\text { 100-NR-2 Operable Unit remedial investigation; also } \\
\text { includes RCRA wells of Hartman (1996) }\end{array}$ \\
\hline \multicolumn{2}{|c|}{100 D Area } \\
\hline CERCLA (ROD 1996a, DOE 1997a) & $\begin{array}{l}\text { CERCLA interim action for chromium; wells near } \\
\text { retention basins and disposal trenches }{ }^{(a)}\end{array}$ \\
\hline CERCLA (ROD 1999) & $\begin{array}{l}100-\mathrm{HR}-3 \text { record of decision amended to include in situ } \\
\text { redox manipulation in southwestern } 100 \mathrm{D} \text { Area. }\end{array}$ \\
\hline $\begin{array}{l}\text { CERCLA (National Priorities List Change Control } \\
\text { Form 107, November 20, 1996) }\end{array}$ & 100-HR-3 (D Area) Operable Unit remedial investigation \\
\hline \multicolumn{2}{|c|}{100 H Area } \\
\hline RCRA (Hartman 1997) & 183-H solar evaporation basins \\
\hline CERCLA (ROD 1996a; DOE 1997a) & CERCLA interim action for chromium $^{(a)}$ \\
\hline $\begin{array}{l}\text { CERLCA (Peterson and Raidl 1996; National } \\
\text { Priorities List Change Control Form 107, } \\
\text { November 20, 1996) }\end{array}$ & 100-HR-3 (H Area) Operable Unit remedial investigation \\
\hline \multicolumn{2}{|c|}{100 F Area } \\
\hline $\begin{array}{l}\text { CERLCA (Federal Facility Agreement and } \\
\text { Consent Order Change Control Form M-15-99-02; } \\
\text { Sweeney 2000b) }\end{array}$ & Long-term plume monitoring \\
\hline
\end{tabular}


Contaminated effluent from leaking retention basins and disposal trenches has reached the soil in the 100 Areas for $\sim 50$ years. Radionuclides with short half-lives decayed in the retention basins or in the vadose zone. Nonradioactive constituents and longer-lived radionuclides were carried down through the vadose zone beneath the waste sites. Some of these sorbed to sediment, some remained in the moisture in the vadose zone, and large quantities were carried into the groundwater (Figure 4.1).

When the reactors were active, huge volumes of water were discharged to the ground, creating large groundwater mounds that disrupted the natural patterns of groundwater flow. The contaminants moved outward on these mounds, contaminating a larger area in the saturated zone than in the vadose zone. The mounds dissipated after discharges ceased, and groundwater flow resumed its normal pattern (i.e., toward the river). Groundwater beneath the 100 Areas continues to carry contaminants to the river, where it discharges from springs, seeps, and through the riverbed below the water line. Groundwater nearest the river often has lower concentrations of contaminants because of dilution. When river stage is high, the water table may rise into the former mound areas and mobilize some constituents (see Figure 4.1) or it may dilute contaminants further. This influx of river water also temporarily disrupts the direction and rate of groundwater flow. Locally, groundwater extraction and injection also affect flow directions and intercept contaminants before they reach the river.

The vertical component of groundwater flow in the 100 Areas is generally upward, and most of the contamination is limited to the unconfined aquifer. However, it is likely that when groundwater mounds were present, there was a significant downward gradient, and several wells that monitor the confined Ringold or basalt-confined aquifers appear to be contaminated.

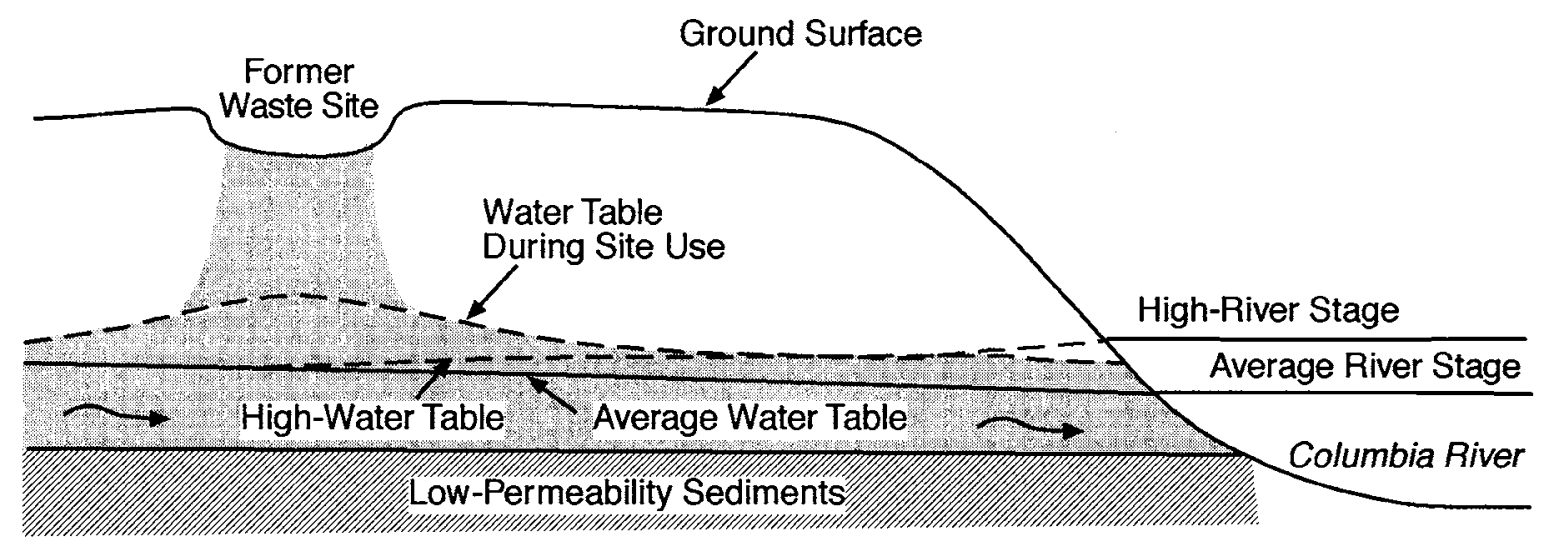

\section{Contaminants}

$\longrightarrow$ Direction of Groundwater Flow

Not to Scale

RG980900050.1

Figure 4.1. Conceptual Model of Subsurface Contamination in the 100 Areas 
Contaminant concentrations are expected to decrease with time because of dispersion, dilution, radioactive decay, remediation, and discharge to the river. There are no new sources of contamination, but concentrations will vary because of plume movement and mobilization of vadose zone contamination.

\subsection{Monitoring Program}

Locations of monitoring wells for the 100 Areas are illustrated in Figures 4.2 through 4.8 and sampling requirements are listed in Appendix A. In addition to the shallow unconfined wells, the network includes most of the few available deeper wells (completed in the confined Ringold or the basaltconfined aquifer). Most of the 600 Area wells will be sampled every 3 years. Wells in the reactor areas are sampled every year, except for those wells near the river or wells with highly variable concentrations that are sampled more frequently. Wells monitoring the in situ redox manipulation application in the $100 \mathrm{D}$ Area are monitored quarterly. 


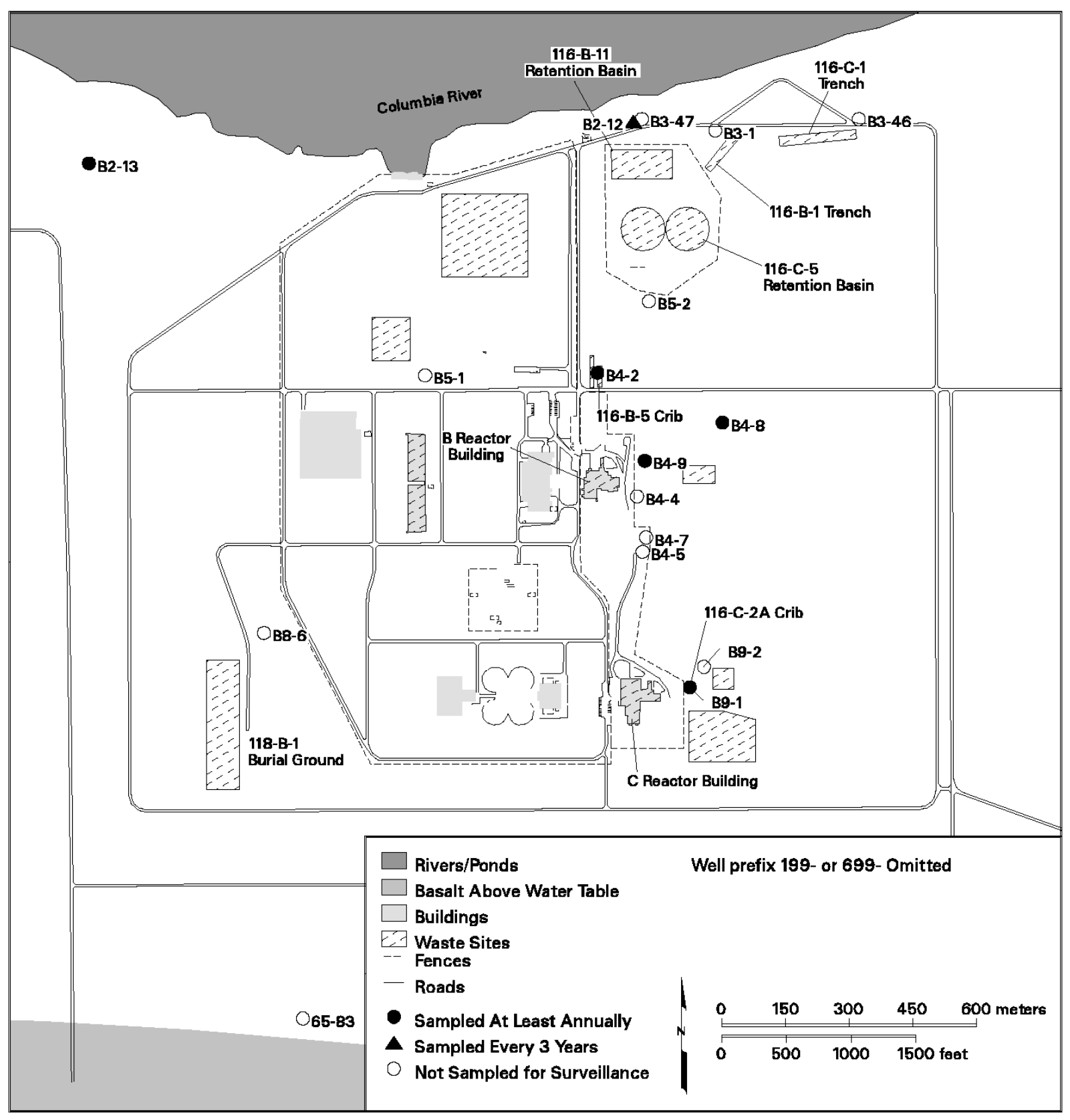

can_harto1_10 October 08, 2001 1:16 PM

Figure 4.2. Groundwater Project Well Locations: 100 B/C Area 


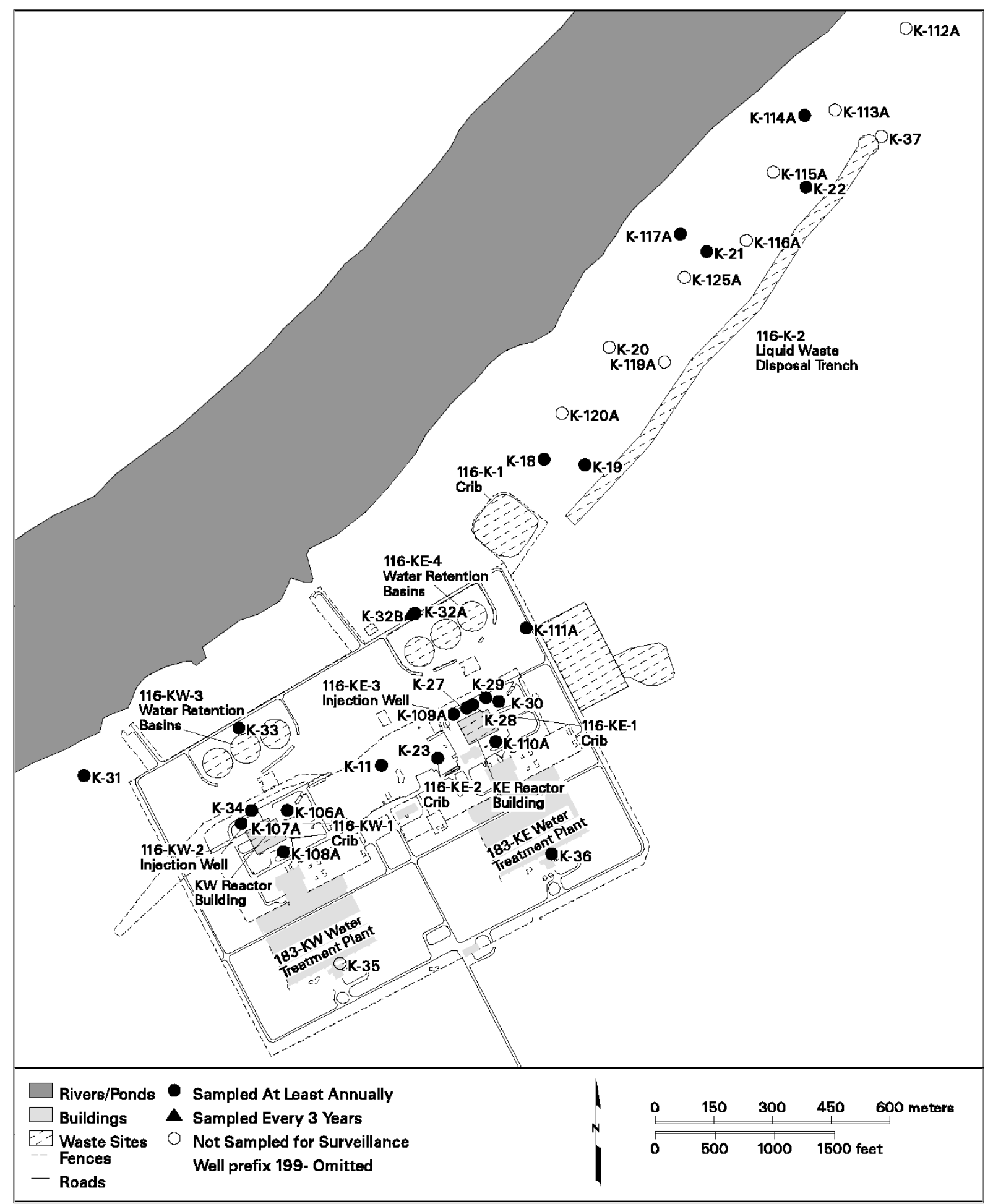

can_harto1_11 Ootober 00, 2001 4:01 PM

Figure 4.3. Groundwater Project Well Locations: $100 \mathrm{~K}$ Area 


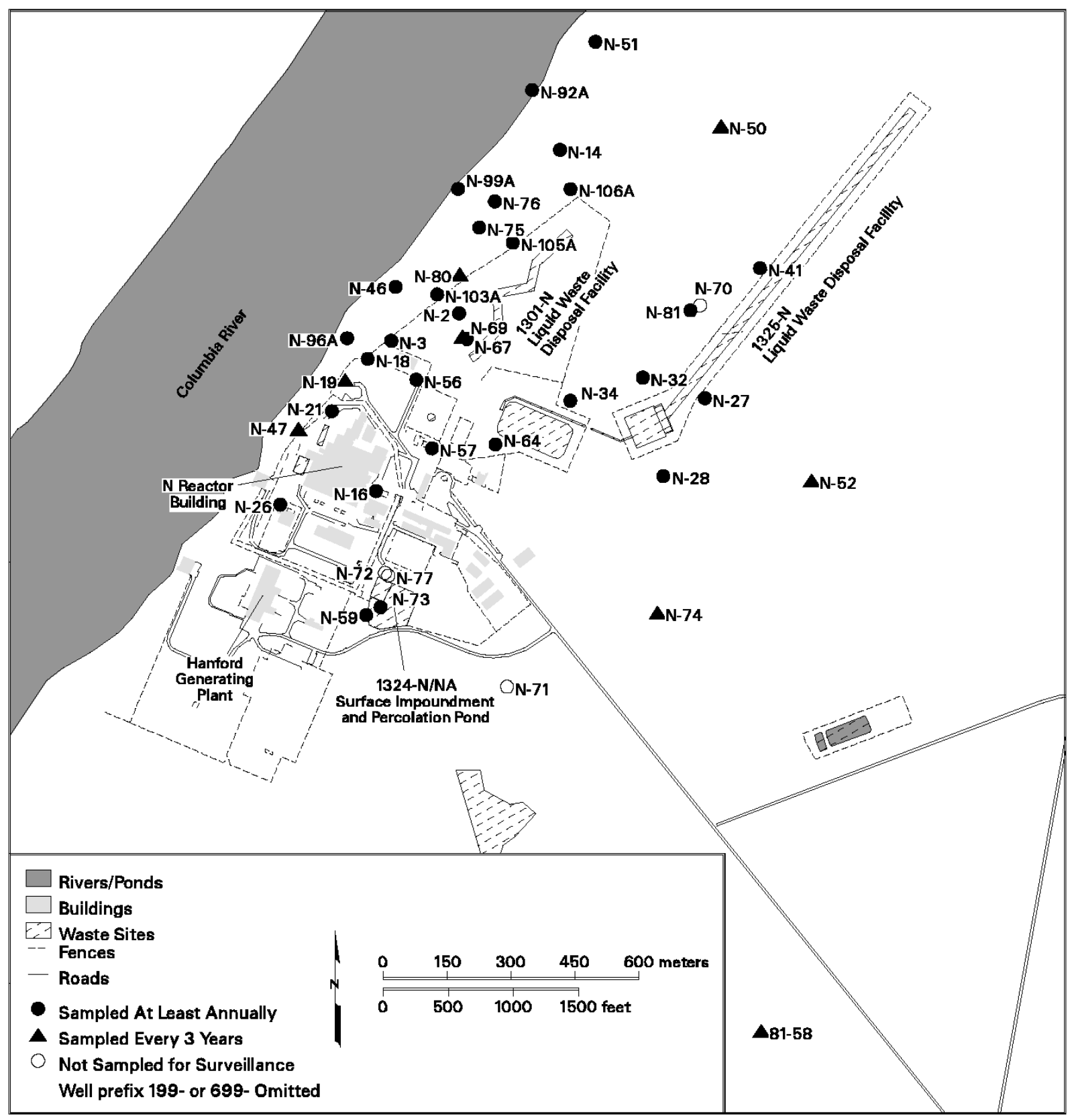

can_hart01_12 October 08, 2001 1:18 PM

Figure 4.4. Groundwater Project Well Locations: 100 N Area 


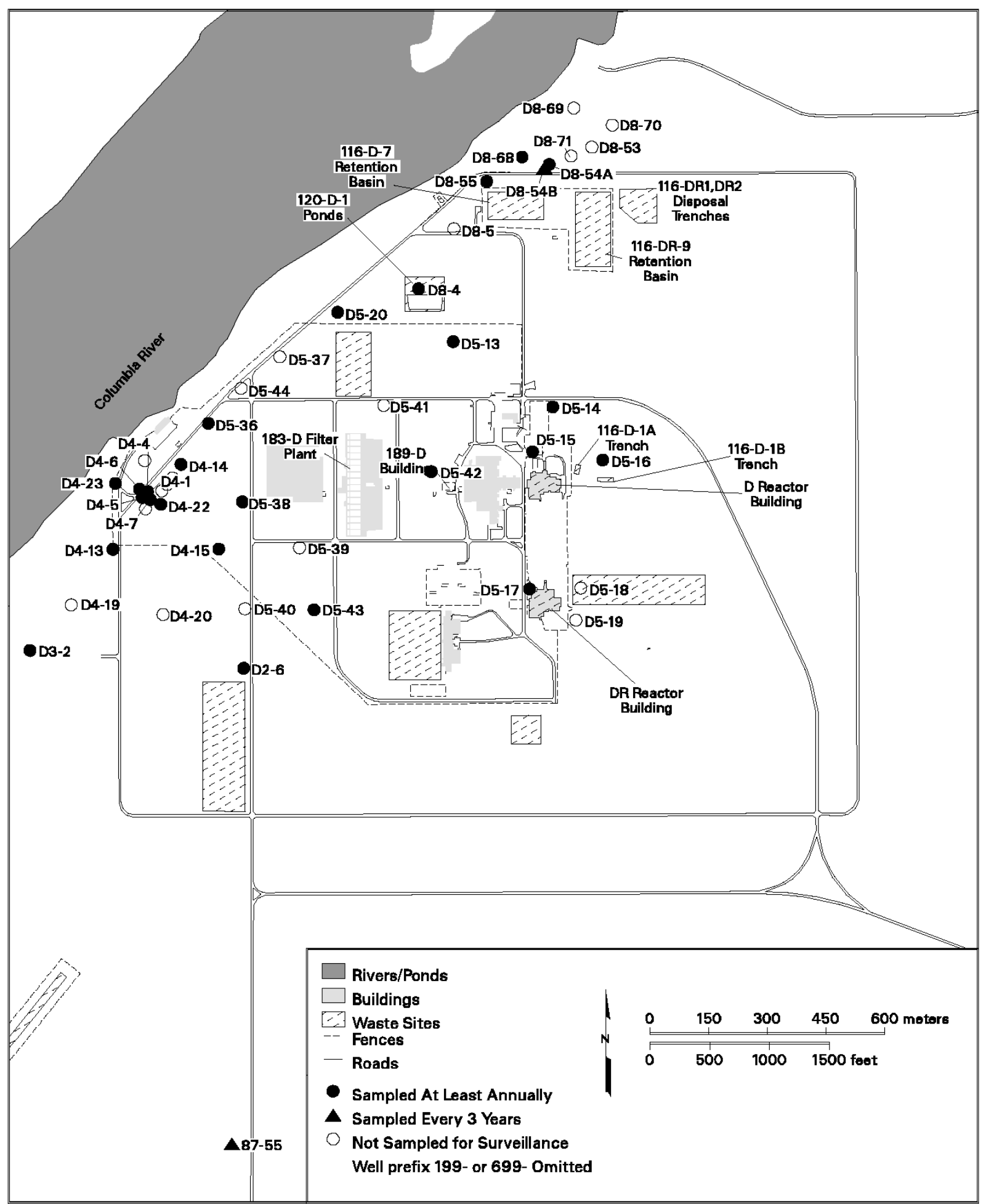

Can_hart01_19 October 08, 2001 1:18 PM

Figure 4.5. Groundwater Project Well Locations: 100 D Area 


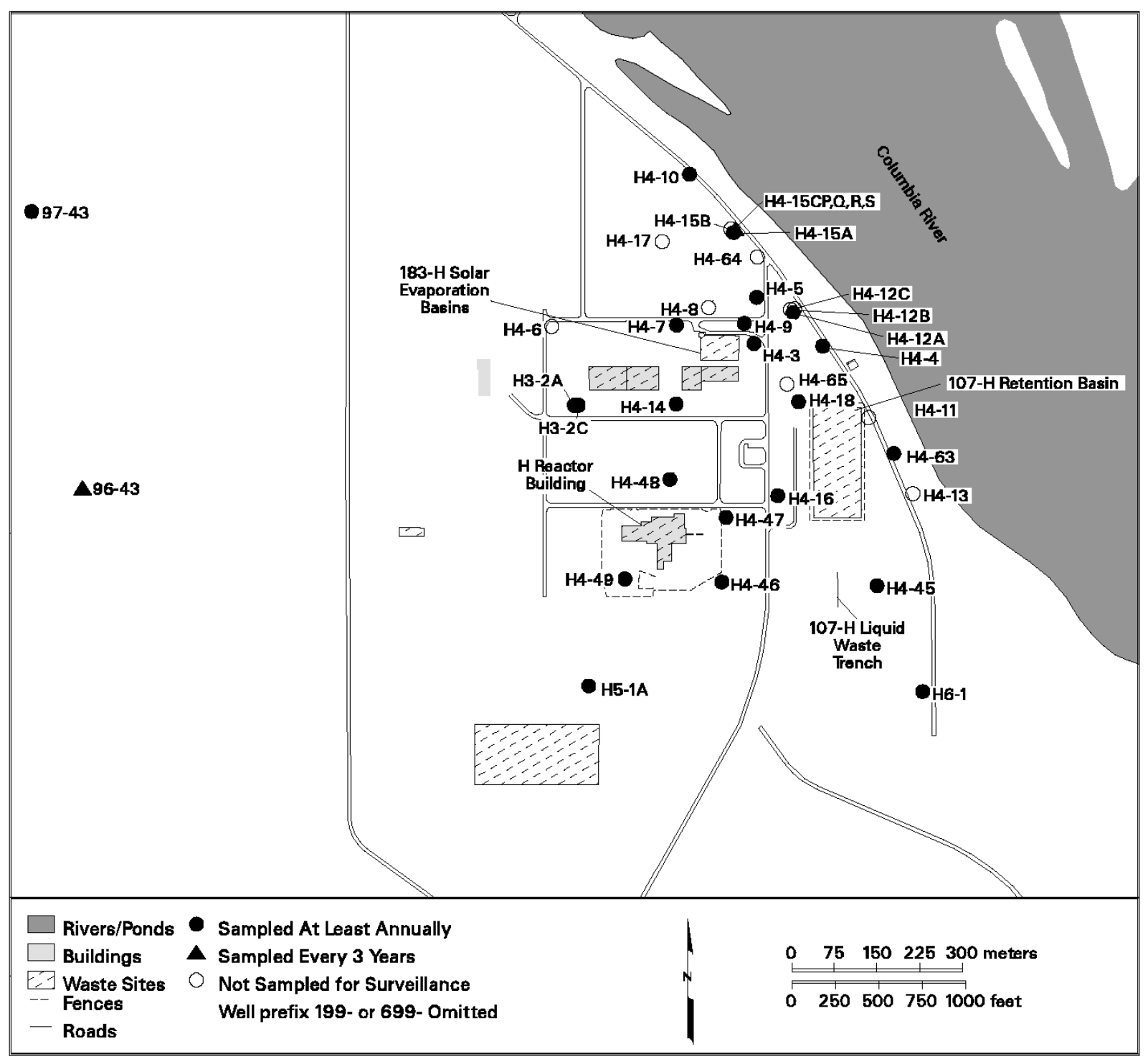

Can_hart01_14 October 08, 2001 4:05 PM

Figure 4.6. Groundwater Project Well Locations: 100 H Area 


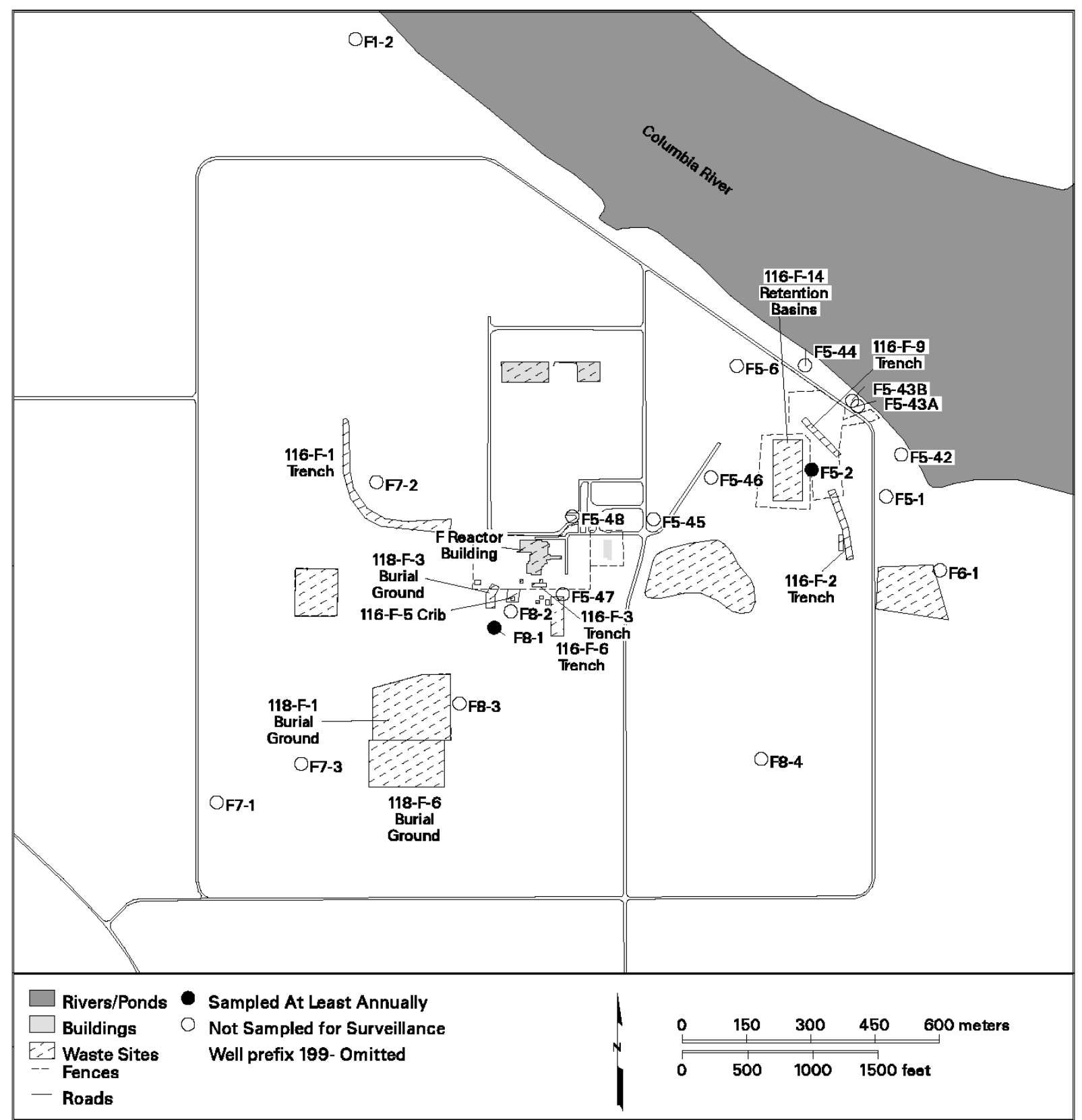

can_hart01_15 October 08, 2001 1:37 PM

Figure 4.7. Groundwater Project Well Locations: 100 F Area 


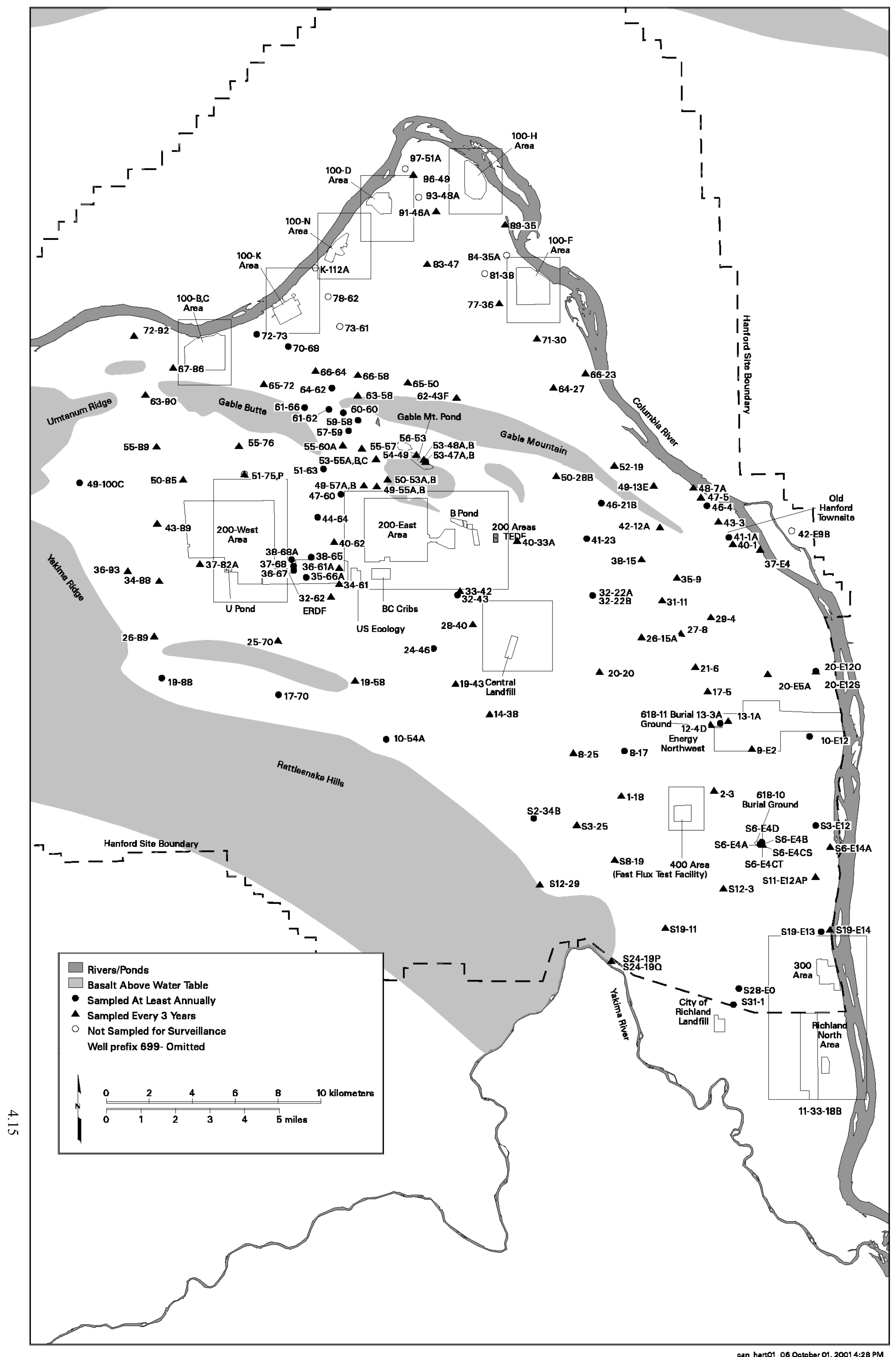

Figure 4.8. Groundwater Project Well Locations: 600 Area 


\subsection{West Area}

The 200 West Area is located on the central plateau of the Hanford Site. Portions of the 600 Area affected by groundwater contamination originating in or near the 200 West Area were evaluated for the monitoring network in this chapter.

\subsection{Background}

This area has been used since the 1940s. Activities within this area have included irradiated nuclear fuel processing and liquid and solid waste storage and disposal.

\subsubsection{Waste Sites, Discharges, and Groundwater Operable Units}

Several processing facilities in the 200 West Area have contributed to groundwater contamination through disposal of radioactive and hazardous liquid waste in ponds, cribs, ditches, and underground storage tanks. Large quantities of solid waste, both from on and off the site, have been disposed of in numerous burial grounds in the $200 \mathrm{West}$ Area. The sites with specific monitoring requirements and those that appear to have affected groundwater quality are listed in Table 5.1. Additional information is provided in Hartman (2000), and more complete site inventories are included in reports listed in the bibliography of Hartman et al. (2001). A number of facilities are regulated under RCRA because they were more recently active and contain, or contained, dangerous chemical waste constituents. Six RCRA units have groundwater monitoring requirements, including two low-level burial grounds, which are the only sites actively receiving waste within the 200 West Area. Four single-shell tank waste management areas located in the 200 West Area also are monitored under RCRA; the tanks currently are used to store mixed waste. The 616-A crib, also known as the State-Approved Land-Disposal Site, is located just north of the 200 West Area. The site consists of a drain field that is used to dispose of liquid waste containing tritium.

Two CERCLA groundwater operable units relate to 200 West Area contamination. The 200-UP-1 Operable Unit generally covers the groundwater in the southeastern part of the area, where technetium-99 and uranium contamination near U Plant are being remediated by a CERCLA interim action. The 200-ZP-1 Operable Unit generally covers groundwater contamination originating in the northwestern part of the 200 West Area, where interim actions are in place to remediate carbon tetrachloride contamination.

\subsubsection{Groundwater Monitoring Requirements and History}

Groundwater monitoring wells in the 200 West Area were installed to monitor specific disposal facilities in the mid 1940s. RCRA monitoring wells were installed beginning in 1987. Several injection and extraction wells have been drilled to support interim-action pump-and-treat systems. The Atomic Energy Act of 1954 and DOE Order 5400.1 require monitoring to identify and track contaminant plumes. This document serves as the monitoring plan for surveillance monitoring per DOE orders. 
Table 5.1. Selected Waste Sites in the 200 West Area $^{(a)}$

\begin{tabular}{|c|c|c|c|}
\hline Facility & Waste Type & $\begin{array}{l}\text { Constituents of Interest } \\
\text { for Groundwater } \\
\text { Monitoring }\end{array}$ & $\begin{array}{l}\text { Type of Site } \\
\text { (monitoring plan } \\
\text { reference) }\end{array}$ \\
\hline $\begin{array}{l}\text { Single-shell tank farms } \\
\text { (Waste Management } \\
\text { Areas S-SX, T, TX-TY, } \\
\text { and U) }\end{array}$ & $\begin{array}{l}\text { Radioactive/chemical } \\
\text { slurries }\end{array}$ & $\begin{array}{l}\text { Sodium hydroxide, } \\
\text { sodium salts, radionu- } \\
\text { clides, ferrocyanide }\end{array}$ & $\begin{array}{l}\text { RCRA (Johnson and } \\
\text { Chou 1999; Hodges and } \\
\text { Chou 2000; Smith et. al } \\
\text { 2001) }\end{array}$ \\
\hline $\begin{array}{l}\text { T Plant disposal facilities } \\
\text { (e.g. 216-T-26, -28, -19, } \\
\text {-25) }\end{array}$ & $\begin{array}{l}\text { Diverse chemical and } \\
\text { radiological waste }\end{array}$ & $\begin{array}{l}\text { Tritium, iodine-129, } \\
\text { technetium-99, nitrate, } \\
\text { chromium, carbon tetra- } \\
\text { chloride, chloroform, } \\
\text { trichloroethene, fluoride }\end{array}$ & $\begin{array}{l}\text { Past-practice (this } \\
\text { document) }\end{array}$ \\
\hline $\begin{array}{l}\text { Reduction-Oxidation } \\
\text { Plant disposal facilities } \\
\text { (including 216-S-10 } \\
\text { pond/ditch) }\end{array}$ & $\begin{array}{l}\text { Solvent-extraction } \\
\text { process waste }\end{array}$ & $\begin{array}{l}\text { Nitrate, trichloroethene, } \\
\text { tritium, iodine-129, } \\
\text { technetium-99, uranium, } \\
\text { strontium-90 }\end{array}$ & $\begin{array}{l}\text { Past-practice, except } \\
\text { S-10: RCRA (Airhart } \\
\text { et al. 1990) }\end{array}$ \\
\hline $\begin{array}{l}\text { U Plant disposal facilities } \\
\text { (216-U-12 and other } \\
\text { retention trenches) }\end{array}$ & $\begin{array}{l}\text { Supernatant from } \\
\text { scavenged waste }\end{array}$ & $\begin{array}{l}\text { Iodine-129, } \\
\text { technetium-99, uranium, } \\
\text { nitrate, trichloroethene }\end{array}$ & $\begin{array}{l}\text { Past-practice, except } \\
\text { U-12: RCRA (Jensen } \\
\text { et al. 1990; Williams and } \\
\text { Chou 1993). 200-UP-1 } \\
\text { interim action (DOE } \\
\text { 1997b; ROD 1997) }\end{array}$ \\
\hline $\begin{array}{l}\text { Plutonium Finishing Plant } \\
\text { disposal facilities (e.g., } \\
\text { 216-Z-1A and -Z-9) }\end{array}$ & $\begin{array}{l}\text { Transuranic and } \\
\text { chemical waste }\end{array}$ & $\begin{array}{l}\text { Nitrate, carbon tetra- } \\
\text { chloride, chloroform, } \\
\text { trichloroethene }\end{array}$ & $\begin{array}{l}\text { Past-practice } 200-Z P-1 \\
\text { interim action (Freeman- } \\
\text { Pollard 1996) }\end{array}$ \\
\hline $\begin{array}{l}\text { Low-level burial grounds } \\
\text { (Waste Management } \\
\text { Areas } 3 \text { and } 4 \text { ) }\end{array}$ & Radioactive solid waste & $\begin{array}{l}\text { Various chemical and } \\
\text { radioactive waste }{ }^{(\mathrm{c})}\end{array}$ & $\begin{array}{l}\text { RCRA (Last and } \\
\text { Bjornstad 1989) }\end{array}$ \\
\hline $\begin{array}{l}\text { 616A crib (State- } \\
\text { Approved Land-Disposal } \\
\text { Site) }\end{array}$ & Treated liquid effluent & Tritium & $\begin{array}{l}\text { Active; WAC permitted } \\
\text { (Barnett 2000) }\end{array}$ \\
\hline $\begin{array}{l}\text { Environmental } \\
\text { Restoration Disposal } \\
\text { Facility }\end{array}$ & $\begin{array}{l}\text { Excavated, contami- } \\
\text { nated soil and debris } \\
\text { (potentially radioactive } \\
\text { and/or hazardous) }\end{array}$ & $\begin{array}{l}\text { None anticipated } \\
\text { (double-lined facility) }\end{array}$ & $\begin{array}{l}\text { Active (Weeks et al. } \\
\text { 1996; Ford 1996) }\end{array}$ \\
\hline \multicolumn{4}{|c|}{$\begin{array}{l}\text { (a) Sites with specific groundwater monitoring requirements and those that appear to have affected } \\
\text { groundwater quality. } \\
\text { (b) Groundwater monitored independently of groundwater project. } \\
\text { (c) Present in waste; not found in groundwater. }\end{array}$} \\
\hline
\end{tabular}




\subsection{Conceptual Model}

The most widespread hazardous chemical contaminants of concern in 200 West Area groundwater are nitrate, carbon tetrachloride, and chloroform. Smaller plumes of chromium, fluoride, and trichloroethene are also present. Iodine-129, technetium-99, tritium, and uranium are the most significant radionuclides in groundwater.

Contaminated effluent has reached the soil from cribs, trenches, tile fields, surface impoundments, and leaking tanks associated with T Plant, Reduction-Oxidation Plant, U Plant, and Plutonium Finishing Plant. Radionuclides with short half-lives decayed in the vadose zone, while nonradioactive constituents and longer-lived radionuclides were carried deeper. Some of these sorbed to sediment, some remained in the moisture in the vadose zone, and large quantities were carried into the groundwater.

The direction of groundwater flow beneath the southern portion of the 200 West Area is to the east. Groundwater flows to the northeast beneath the northern part of the area. In the past, waste-disposal practices created groundwater mounds that caused some westward flow of contaminants. Contaminants moved outward from these mounds, contaminating a larger area in the saturated zone than in the vadose zone. These mounds are still present but are declining, and the most recent information indicates that the westward flow has ceased. Interim remedial action systems, where groundwater is extracted, treated, and reinjected, locally perturb groundwater flow directions near the Plutonium Finishing Plant and east of U Plant.

The few shallow and deep well pairs indicate that the vertical flow gradient is downward in the 200 West Area. Contamination in the deeper parts of the unconfined aquifer appears to be considerably less than in the upper portion of the aquifer. However, very few wells monitor the deeper portions of the aquifer, and at some locations certain contaminants are found at greater concentrations at depth.

Contaminant concentrations are expected to decrease with time because of dispersion, dilution, radioactive decay, remediation, and migration. There are no new sources of contamination, but concentrations will vary because of plume movement and mobilization of vadose zone contamination.

\subsection{Monitoring Program}

The primary objective of surveillance monitoring in the 200 West Area is to monitor the extent of plumes originating from 200 West Area waste sites. Most of the sites have ceased operation, and many wells monitoring the widespread plumes will be sampled annually since plume dimensions and concentrations continue to change significantly in this vicinity. Other wells will be sampled more frequently.

Another objective of surveillance monitoring is to monitor hazardous waste sites that ceased operation before 1985 and radioactive waste sites, which are not regulated by RCRA. Wells are monitored near the most significant sources to determine whether contaminants are declining as expected and to detect contaminants migrating from the vadose zone. These wells are monitored annually or more frequently. 
The carbon tetrachloride network for monitoring the top of the aquifer was reevaluated using a geostatistical analysis in fiscal year 2000. Carbon tetrachloride was chosen for this evaluation because it is the most widespread contaminant in the area and is a major driver for groundwater remediation. Thus, many wells are monitored for carbon tetrachloride and the groundwater project decided that the geostatistical evaluation would improve the efficiency of the monitoring system. This analysis was described in the previous revision of this integrated monitoring plan (Hartman et al. 2000). After application of the geostatistical analysis, a large number of changes were made in the carbon tetrachloride monitoring. These changes include wells going dry, new wells being drilled, and modifications to well and/or constituent lists for existing projects. To capture the most recent changes, the simulations were rerun on the candidate fiscal year 2001 monitoring network. The results of the simulations were used to reduce the monitoring network where possible.

The locations of the monitoring wells in the 200 West Area are illustrated in Figure 5.1 (600 Area wells were shown in Figure 4.8). Wells and constituents are listed in Appendix A. 


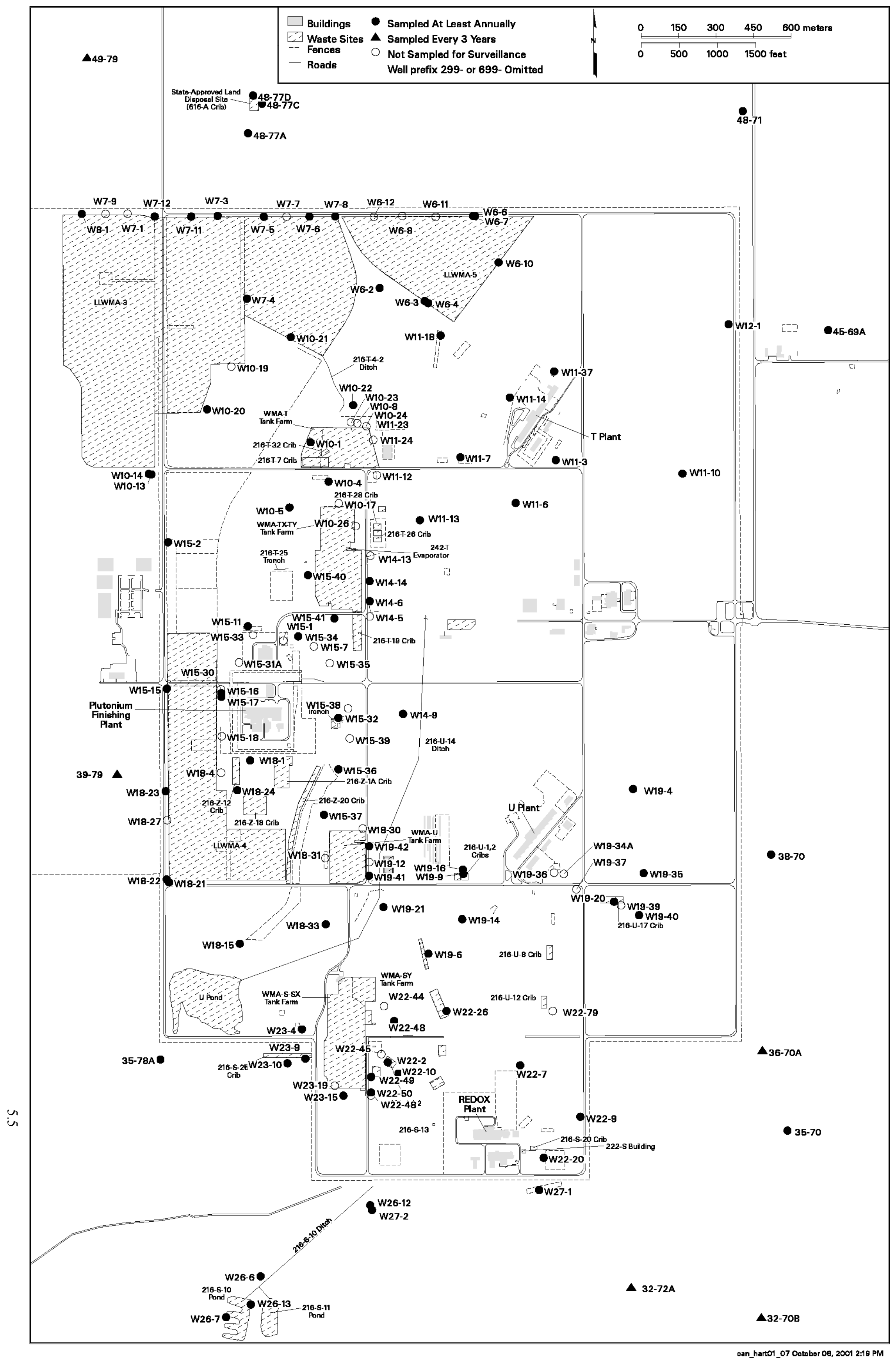

Figure 5.1. Groundwater Project Well Locations: 200 West Area 


\subsection{East Area}

For the purposes of this plan, "200 East Area" describes that portion of the Hanford Site within the 200 East Area fence line, those parts of the site downgradient from the area that shows impacts by contaminants originating in the 200 East Area, and those disposal facilities outside the fence line but associated with 200 East Area operations. Thus, B Pond, Gable Mountain Pond, and BC Cribs are included in the following discussion. The 200 Areas Treated Effluent Disposal Facility also falls generally within this part of the site but is monitored under the specific requirements of its state wastedischarge permit.

\subsection{Background}

Hundreds of waste sites have been identified in the 200 East Area, including radioactive and mixed waste-storage tanks; low-level burial grounds; effluent disposal cribs, ditches, drains, and ponds; and various spills or other unplanned releases. Sites with specific monitoring requirements and those that appear to have affected groundwater quality are listed in Table 6.1. Additional information is provided in Hartman (2000). A number of facilities are regulated under RCRA because they were more recently active and contain, or contained, dangerous waste constituents.

\subsubsection{Waste Sites, Discharges, and Groundwater Operable Units}

The 200 Areas Treated Effluent Disposal Facility, located east of the 200 East Area proper, is the only active liquid disposal facility in the area. As mentioned above, this is monitored under a state waste discharge permit. The permitted discharge does not include radioactive or hazardous constituents. LowLevel Waste Management Areas 1 and 2 are burial grounds regulated under RCRA, which continue to receive radioactive solid waste. Three single-shell tank waste management areas, also regulated under RCRA, no longer actively receive waste but currently store mixed waste.

Groundwater in the northwestern part of the 200 East Area forms the 200-BP-5 Operable Unit, while the southeastern part of the site is in the 200-PO-1 Operable Unit. Remediation of the 200-BP-5 unit is being performed under CERCLA regulations, and 200-PO-1 is being remediated under RCRA regulations, though requirements of both regulations are considered in the cleanup process. Two groundwater extraction treatability tests were performed in the 200-BP-5 Operable Unit - the first near the 216-B-5 injection well and the second just north of the northwestern corner of the 200 East Area in an area of contamination originating in the BY cribs. There is no active groundwater remediation in the 200 East Area. The interim action recommended in the Hanford Sitewide Groundwater Remediation Strategy (DOE 1995a) is natural attenuation and decay of contaminant plumes. There is, however, no interim or final record of decision for the operable units in the 200 East Area. 
Table 6.1. Selected Waste Sites in and Downgradient of the 200 East Area

\begin{tabular}{|c|c|c|c|}
\hline Facility (period of use) & Waste Type & $\begin{array}{l}\text { Constituents of Interest } \\
\text { for Groundwater } \\
\text { Monitoring }\end{array}$ & $\begin{array}{l}\text { Type of Site } \\
\text { (monitoring plan } \\
\text { reference) }\end{array}$ \\
\hline \multicolumn{4}{|c|}{200 East Area Proper and Adjacent Facilities } \\
\hline $\begin{array}{l}\text { Single-shell tank farms } \\
\text { (Waste Management Areas } \\
\text { A-AX, B-BX-BY, C) }\end{array}$ & $\begin{array}{l}\text { Radioactive/chemical } \\
\text { slurries }\end{array}$ & $\begin{array}{l}\text { Sodium hydroxide, } \\
\text { sodium salts, radionu- } \\
\text { clides, ferrocyanide }\end{array}$ & $\begin{array}{l}\text { RCRA (Narbutovskih, } \\
\text { 2000; Narbutovskih and } \\
\text { Horton 2001; Horton and } \\
\text { Narbutovskih 2001) }\end{array}$ \\
\hline 216-B-7A, $-7 \mathrm{~B},-8$ cribs & $\begin{array}{l}\text { Supernatant from } \\
\text { settling tanks }\end{array}$ & $\begin{array}{l}\text { Sodium hydroxide, } \\
\text { sodium salts, radionu- } \\
\text { clides, ferrocyanide }\end{array}$ & $\begin{array}{l}\text { Past-practice (200-BP-5 } \\
\text { Operable Unit; TPA } \\
\text { M-15-96-04) }\end{array}$ \\
\hline 216-B-37 trench & $\begin{array}{l}\text { Concentrated waste } \\
\text { from tank bottoms }\end{array}$ & $\begin{array}{l}\text { Sodium hydroxide, } \\
\text { sodium salts, radionu- } \\
\text { clides, ferrocyanide }\end{array}$ & $\begin{array}{l}\text { Past-practice (200-BP-5 } \\
\text { Operable Unit; TPA } \\
\text { M-15-96-04) }\end{array}$ \\
\hline $\begin{array}{l}\text { 216-B-5 injection well } \\
(1945-1946)\end{array}$ & $\begin{array}{l}\text { Hot cell drainage; } \\
\text { supernatant from } \\
\text { settling tanks }\end{array}$ & $\begin{array}{l}\text { Strontium-90, } \\
\text { cesium-137, plutonium }\end{array}$ & $\begin{array}{l}\text { Past-practice (200-BP-5 } \\
\text { Operable Unit; TPA } \\
\text { M-15-96-04) }\end{array}$ \\
\hline $\begin{array}{l}\text { BY cribs and trench (1954- } \\
1955)\end{array}$ & $\begin{array}{l}\text { Uranium-recovery waste } \\
\text { supernatant }\end{array}$ & $\begin{array}{l}\text { Ferrocyanide, } \\
\text { radionuclides }\end{array}$ & $\begin{array}{l}\text { Past-practice (200-BP-5 } \\
\text { Operable Unit; TPA } \\
\text { M-15-96-04) }\end{array}$ \\
\hline $\begin{array}{l}\text { 216-B-63 trench } \\
(1970-1992)\end{array}$ & Steam condensate & $\begin{array}{l}\text { Sulfuric acid, sodium } \\
\text { hydroxide, radionuclides }\end{array}$ & RCRA (Sweeney 1995a) \\
\hline $\begin{array}{l}\text { Plutonium-Uranium } \\
\text { Extraction Plant waste- } \\
\text { disposal cribs }\end{array}$ & Process distillate & $\begin{array}{l}\text { Radionuclides } \\
\text { (especially tritium, } \\
\text { iodine-129, strontium- } \\
\text { 90), nitrate }\end{array}$ & $\begin{array}{l}\text { 216-A-10, -36B, -37-1: } \\
\text { RCRA (Lindberg 1997); } \\
\text { others: past-practice } \\
\text { (200-PO-1 Operable Unit; } \\
\text { DOE 1997c) }\end{array}$ \\
\hline $216-A-29$ ditch & $\begin{array}{l}\text { Plutonium-Uranium } \\
\text { Extraction Plant chemi- } \\
\text { cal waste }\end{array}$ & $\begin{array}{l}\text { Sodium hydroxide, } \\
\text { sulfuric acid }\end{array}$ & RCRA (Sweeney 1999) \\
\hline 216-B-3 pond (B Pond) & $\begin{array}{l}\text { B Plant steam conden- } \\
\text { sate and chemical waste; } \\
\text { Plutonium-Uranium } \\
\text { Extraction Plant chemi- } \\
\text { cal waste }\end{array}$ & $\begin{array}{l}\text { Tritium, aluminum } \\
\text { nitrate, potassium } \\
\text { hydroxide, nitric acid, } \\
\text { sulfuric acid }\end{array}$ & RCRA (Sweeney 1995b) \\
\hline $\begin{array}{l}200 \text { Areas Treated } \\
\text { Effluent-Disposal Facility }\end{array}$ & $\begin{array}{l}\text { Treated liquid effluent } \\
\text { from } 200 \text { Areas }\end{array}$ & Trihalomethane & $\begin{array}{l}\text { Active; WAC permitted } \\
\text { (Barnett 2000) })^{\text {(a) }}\end{array}$ \\
\hline $\begin{array}{l}\text { Low-Level Burial Grounds } \\
\text { (Waste Management Areas } \\
1 \text { and 2) }\end{array}$ & Radioactive solid waste & $\begin{array}{l}\text { Various chemical and } \\
\text { radioactive waste } \\
\text { (b) }\end{array}$ & $\begin{array}{l}\text { RCRA (Last and } \\
\text { Bjornstad 1989) }\end{array}$ \\
\hline
\end{tabular}


Table 6.1. (contd)

\begin{tabular}{||l|l|l|l||}
\hline \multicolumn{1}{|c|}{ Facility (period of use) } & \multicolumn{1}{|c|}{ Waste Type } & $\begin{array}{l}\text { Constituents of Interest } \\
\text { for Groundwater } \\
\text { Monitoring }\end{array}$ & \multicolumn{1}{c||}{$\begin{array}{c}\text { Type of Site } \\
\text { (monitoring plan } \\
\text { reference) }\end{array}$} \\
\hline \hline $\begin{array}{l}\text { Liquid Effluent Retention } \\
\text { Facility }\end{array}$ & $\begin{array}{l}\text { 242-A evaporator } \\
\text { process condensate }\end{array}$ & $\begin{array}{l}\text { Ammonium, acetone, } \\
\text { aluminum, 1-butanol, } \\
\text { 2-butanone, tritium, } \\
\text { strontium-90, } \\
\text { ruthenium-106, } \\
\text { cesium-137 }\end{array}$ & RCRA (Schmid 1990) \\
\hline \multicolumn{2}{|c|}{$\mathbf{6 0 0}$ Area Facilities } \\
\hline $\begin{array}{l}\text { Gable Mountain Pond } \\
\text { (1957-1987) }\end{array}$ & $\begin{array}{l}\text { 200 East Area liquid } \\
\text { waste }\end{array}$ & $\begin{array}{l}\text { Strontium-90, } \\
\text { cesium-137, } \\
\text { ruthenium-106 }\end{array}$ & Inactive (this document) \\
\hline $\begin{array}{l}\text { BC Cribs and Trenches } \\
\text { (1956-1958) }\end{array}$ & $\begin{array}{l}\text { Uranium recovery waste } \\
\text { supernatant }\end{array}$ & $\begin{array}{l}\text { Ferrocyanide, } \\
\text { radionuclides }\end{array}$ & $\begin{array}{l}\text { Past-practice (this } \\
\text { document) }\end{array}$ \\
\hline $\begin{array}{l}\text { (a) Groundwater monitored independently of groundwater project. } \\
\text { (b) Present in waste; not found in groundwater. }\end{array}$ \\
\hline
\end{tabular}

\subsubsection{Groundwater Monitoring Requirements and History}

Groundwater monitoring has been conducted in the 200 East Area since the 1940s. Very few monitoring wells existed in the early decades but more were installed in the 1970s and monitored for DOE requirements. Approximately 100 new wells were installed when RCRA monitoring began in the late 1980s. CERCLA investigations in the 1990s resulted in the installation of several wells but relied primarily on data from existing groundwater monitoring networks and additional wells installed in support of RCRA.

The Atomic Energy Act of 1954 and DOE Order 5400.1 require monitoring to identify and track contaminant plumes. This document serves as the monitoring plan for surveillance monitoring per DOE orders.

\subsection{Conceptual Model}

The most widespread groundwater contaminants of concern originating from the 200 East Area are iodine-129, nitrate, and tritium. These contaminants extend east and southeast of the 200 East Area to the Columbia River and northwest to the gap between Gable Mountain and Gable Butte. A significant plume of technetium-99 at levels above the drinking water standards extends northwest from the 200 East Area fence line toward the gap between Gable Mountain and Gable Butte. This plume area also contains low levels of cobalt-60 and cyanide. Arsenic is found at levels above drinking water standards in the eastern part of the 200 East Area. Groundwater is locally contaminated with strontium-90 at high levels near Gable Mountain Pond (decommissioned) and at low levels near cribs south of the Plutonium-Uranium Extraction Plant. Contamination with cesium-137, plutonium, and strontium-90 is found in the immediate vicinity of the 216-B-5 injection well. Localized uranium and chromium contamination is also found. 
The most extensive contaminant plumes are attributable predominantly to liquid discharges to cribs, with some contribution from ponds, ditches, and other sources. Most pond discharge, however, was more dilute and did not contribute to the highest levels of contamination. The ponds, particularly 216-B-3 pond (B Pond), did have a large influence on contaminant migration because the large amounts of water that went to the ponds affected flow directions. Contamination from tank leaks, unplanned releases, and specific retention trenches appears to have produced groundwater contamination of limited extent, though considerable inventory may remain in the vadose zone. No groundwater impact from low-level wasteburial grounds in the 200 East Area has been identified.

Contaminant levels are declining through much of the 200 East Area. Many short-lived radionuclides detected in the past, such as cobalt-60 and ruthenium-106 are no longer detected or are detected at much lower concentrations. Tritium concentrations near the source areas are declining because waste discharges have ended and the subsequent dispersion and decay within the plume. Data indicate that residual contamination in the vadose zone at many of the sources continues to drain into the groundwater. It is expected that the amount of transport to groundwater will decline with time. Some contaminants that have been retarded by sorption to sediment or that never reached groundwater because of limited discharge volumes (i.e., specific retention trenches) may break through to the water table, and concentrations then could increase. In addition, any uncontrolled discharge, such as leaks from water lines, may enhance transport of contaminants to the groundwater from the vadose zone. The major tritium plume, which is flowing eastward and southeastward from the 200 East Area toward the Columbia River, ceased expanding laterally (southward) into the 300 Area in about 1995 because of dispersion and decay. Tritium is still detected in the northern part of the 300 Area, but the concentrations are no longer increasing.

Vertical migration of contaminants to deeper parts of the aquifer or deeper aquifers may have occurred through several mechanisms. Significant groundwater mounds developed at a number of facilities. By far, the greatest mounding occurred at B Pond, where monitoring evidence indicates there was some movement of contamination down to the upper basalt-confined aquifer. This mounding produced vertical gradients to transport contamination downward in the sedimentary sequence. Poorly sealed wells may have produced conduits, thus enhancing vertical migration.

Another mechanism for vertical migration is the intersection of the water table by confining layers in the suprabasalt sediments. The lower Ringold mud intersects the water table downgradient of B Pond and dips approximately to the south. This serves to induce downward flow to the sediment below the confining mud. The lower part of the Ringold Formation sediment, therefore, forms a confined aquifer in this area. Although relatively few wells are completed below the lower Ringold mud, this interval is monitored where wells are available. Several wells near B Pond and the 200 Area Treated Effluent Disposal Facility are completed below the lower mud.

\subsection{Monitoring Program}

The surveillance monitoring program in the 200 East Area has been designed to meet several objectives and to complement the RCRA monitoring networks. The first objective is to monitor the extent of plumes emanating from 200 East Area waste sites. Most of these sites have ceased operations, and it is 
expected that the monitoring network will be suitable to track the rate of dissipation and attenuation of the plumes. A combination of geostatistical assessment and site knowledge was used to develop the plumemonitoring system.

The large contaminant plumes downgradient (east to southeast) of the 200 East Area do not change rapidly. Therefore, many of the wells are sampled at 1 to 3 year intervals rather than more frequently.

Three bands of guard wells will be monitored annually for a longer list of constituents to ensure that the nature of contamination found downgradient of the operational and waste disposal areas has been sufficiently characterized. These bands are shown in Figure 6.1; the wells are listed in Table 6.2. One band is located in the gap between Gable Mountain and Gable Butte and serves to detect contaminant movement to the north. The second band is located to the southeast of the 200 East Area and detects contamination moving into the southern and eastern parts of the site. The third band is along the Columbia River to provide assurance that offsite effects are identified. In addition to the known contaminants, wells in these bands will be monitored for inductively coupled-plasma metals, anions, gross alpha, gross beta, gamma, strontium-90, technetium-99, tritium, total organic halides, total organic carbon, and alkalinity.

The monitoring network is also designed to complement the RCRA detection and assessment monitoring of contaminant sources. RCRA-monitoring networks monitor hazardous waste sources that were operational after 1985. RCRA and past-practice source monitoring serves to ensure that concentrations of groundwater contaminants are declining near the most significant sources and to detect the breakthrough of new contamination from the vadose zone.

Locations of monitoring wells for the 200 East Area are illustrated in Figure 6.2 (wells in the 600 Area were shown in Figure 4.8). Wells and constituents are listed in Appendix A. 


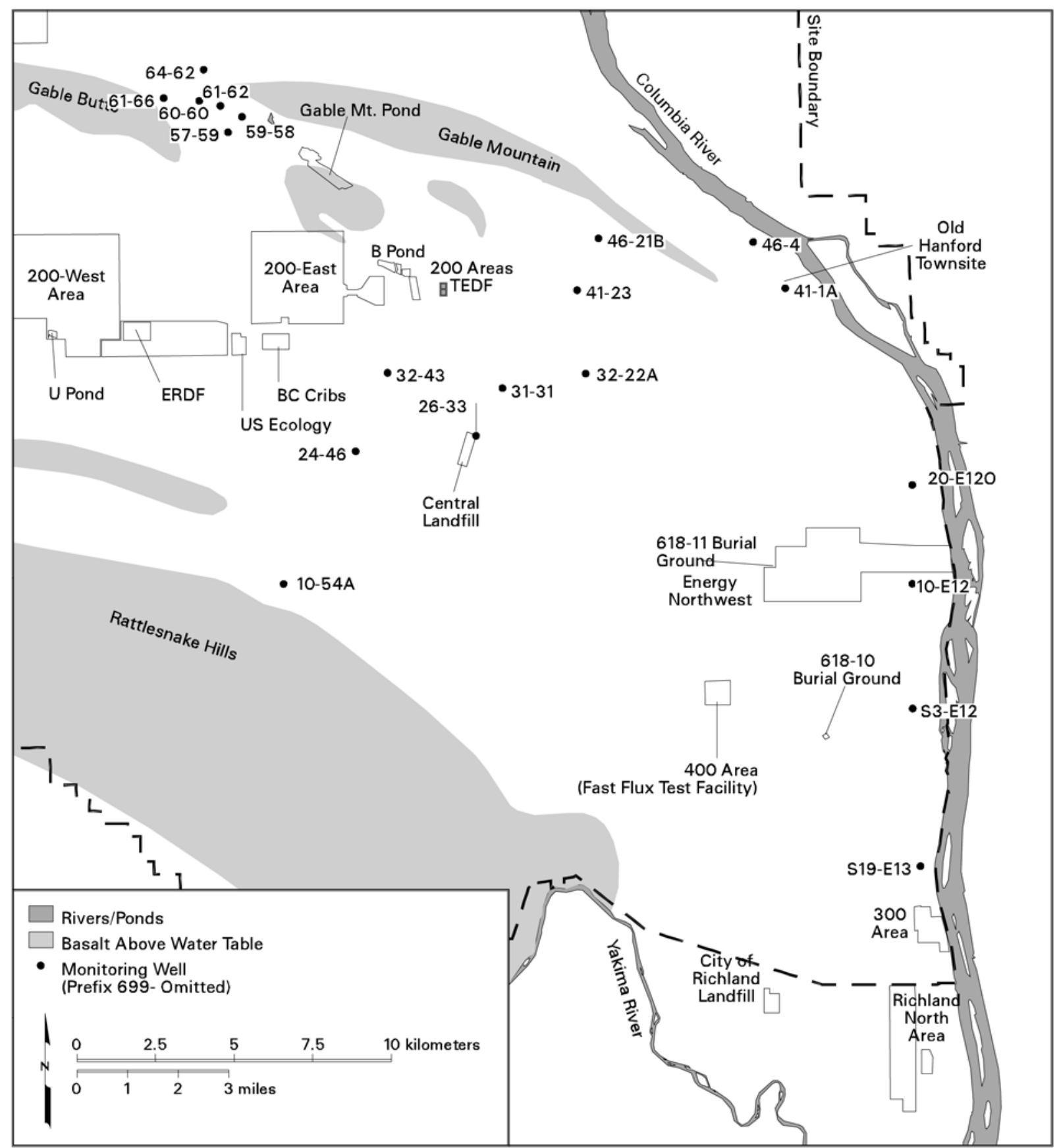

can_hart_99016 September 20, 2000 5:23 PM

Figure 6.1. Locations of 200 East Area Guard Wells 
Table 6.2. 200 East Area Guard Wells

\begin{tabular}{|c|c|c|}
\hline Gap & Southeast & River \\
\hline $699-57-59$ & 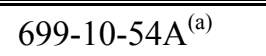 & 699-10-E12 \\
\hline $699-59-58$ & $699-24-46$ & 699-20-E12O \\
\hline $699-60-60$ & 699-26-33 & $699-41-1 \mathrm{~A}$ \\
\hline 699-61-62 & 699-31-31 & $699-46-4$ \\
\hline $699-61-66$ & $699-32-22 \mathrm{~A}$ & 699-S3-E12 \\
\hline 699-64-62 & $699-32-43$ & 699-S19-E13 (b) \\
\hline & $699-41-23^{(a)}$ & \\
\hline & $699-46-21 B^{(a)}$ & \\
\hline \multicolumn{3}{|c|}{$\begin{array}{l}\text { Constituent List: Inductively coupled-plasma metals; anions; gross } \\
\text { alpha, beta, and gamma; strontium-90; technetium-99; tritium; total } \\
\text { organic halides; total organic carbon; and alkalinity. }\end{array}$} \\
\hline \multicolumn{3}{|c|}{$\begin{array}{l}\text { (a) Reduced list - sample tritium, alpha, beta, anions annually; Full } \\
\text { list - sample every } 3 \text { years. }\end{array}$} \\
\hline \multicolumn{3}{|c|}{ (b) Also monitors southern portion of the Hanford Site. } \\
\hline
\end{tabular}




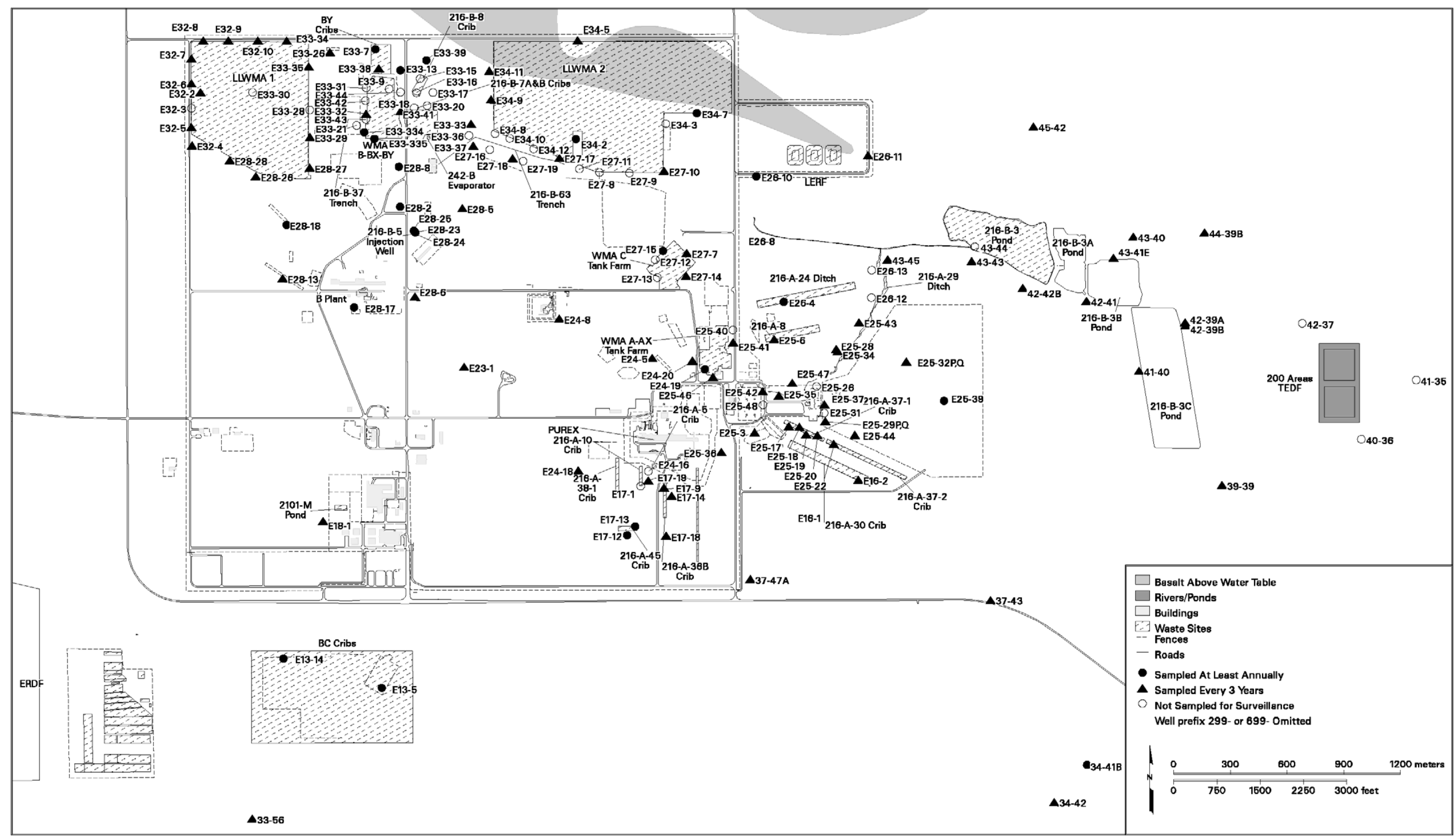

Figure 6.2. Groundwater Project Well Locations: 200 East Area 


\subsection{Area}

\subsection{Background}

This section covers activities in the 400 Area, the location of the Fast Flux Test Facility, a liquid sodium-cooled reactor. The reactor is on standby, pending a restart decision for the production of medical isotopes and tritium.

Primary local groundwater monitoring activities include the area around the $4608 \mathrm{~B} / \mathrm{C}$ ponds (also called the 400 Area process ponds), which receive wastewater effluent. The water supply for the 400 Area, including the drinking water supply, is also monitored by sampling wells completed in the unconfined aquifer system.

\subsubsection{Waste Sites}

The 400 Area process ponds are located north of the 400 Area perimeter fence and are unlined infiltration ponds that receive wastewater from the 400 Area facilities (Figure 7.1). The waste stream consists primarily of cooling water and intermittent small contributors such as sinks and drains.

\subsubsection{Groundwater Monitoring Requirements and History}

The 400 Area process ponds are monitored in accordance with State Waste Discharge Permit ST4501, issued on August 1, 1996 and modified on February 10, 1998. This integrated groundwater monitoring plan provides requirements for sampling activities and quality assurance/quality controls to ensure that the data needs of various users are satisfied. The primary objective of groundwater monitoring at this facility is to ensure that wastewater entering the ponds meets acceptable standards and does not adversely affect local groundwater quality. The monitoring network includes two downgradient wells (699-2-6A and 699-2-7), shown in Figure 7.1, and an upgradient well (699-8-17), shown in Figure 4.8. Constituents analyzed in quarterly groundwater samples, as specified by the discharge permit, include unfiltered metals (cadmium, chromium, lead, mercury, and manganese), $\mathrm{pH}$, sulfate, and total organic carbon. In addition, the wells are co-sampled for surveillance monitoring for other constituents, as indicated in Appendix A.

Nitrate is the only contaminant that has been consistently identified at concentrations above regulatory limits in the local groundwater monitoring network for the 400 Area process ponds, where it has been monitored in well 699-2-7 since 1986. This is attributed to a sanitary sewage lagoon formerly located immediately west and upgradient of the ponds and later to a drainfield associated with septic tanks located southwest of the ponds. Disposal to the lagoon was discontinued in 1983 or 1984 and to the drainfield in April of 1997; thus, groundwater contamination from these sources is expected to diminish with time. Nitrate concentration levels in well 699-2-6A are relatively low, apparently due to the low nitrate content of the effluent disposed to the ponds. 


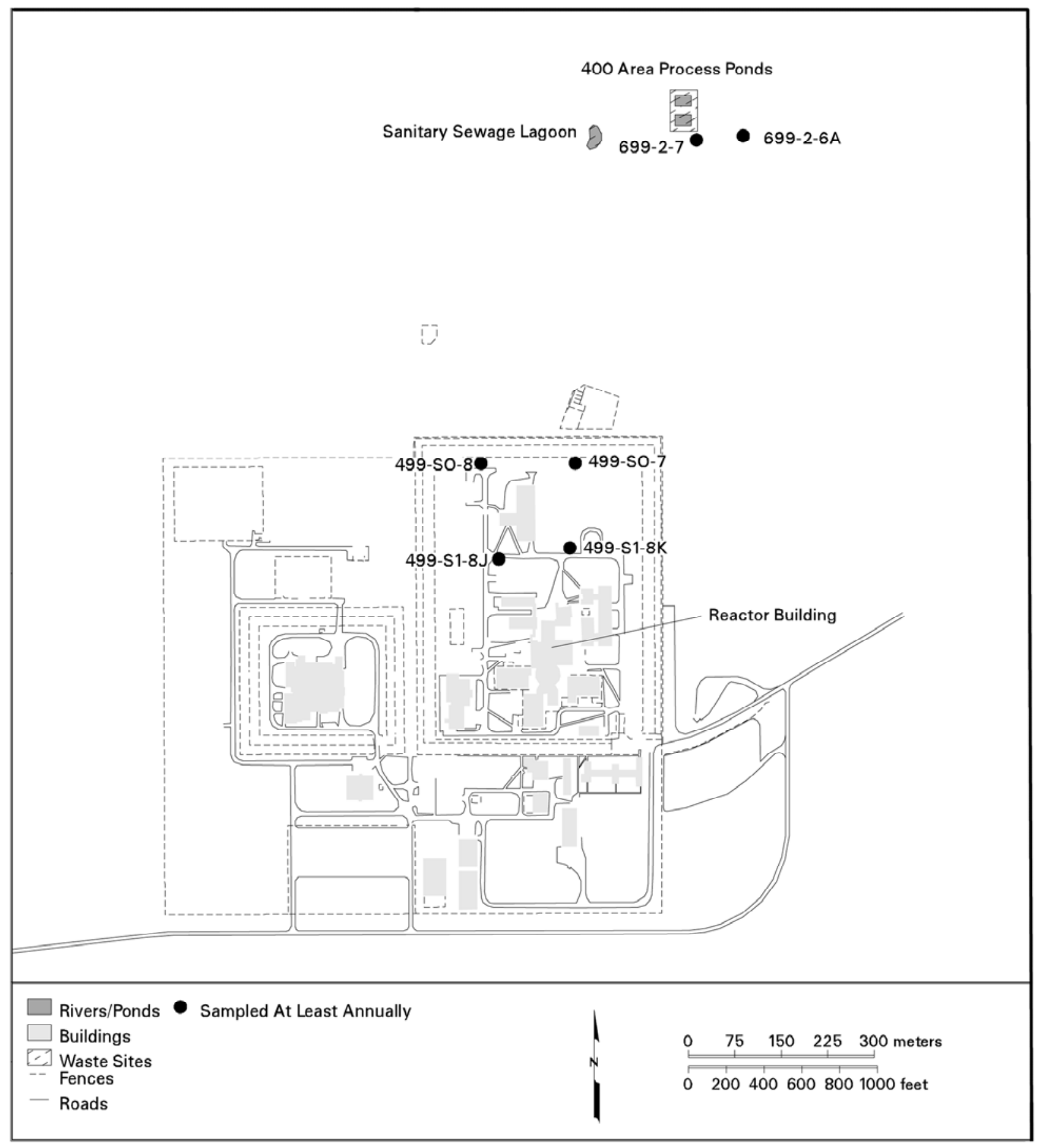

can_hart_99015 September 21, 1999 1:26 PM

Figure 7.1. Groundwater Project Well Locations: 400 Area 
The primary groundwater monitoring compliance issue related to the 400 Area water supply is related to tritium. Wells 499-S0-7 and 499-S0-8, the original water-supply wells, were completed near the top of the unconfined aquifer and have been monitored since 1972. When tritium contamination was detected in the water supply, an additional well (499-S1-8J) was drilled in the lower unconfined aquifer in 1985. Tritium levels of water samples collected from well 499-S1-8J are well below the interim $20,000 \mathrm{pCi} / \mathrm{L}$ drinking water standard and this well is currently used as the primary water-supply well. Wells 499-S0-7 and 499-S0-8 are still used for backup supply and emergency uses, but based on DOE direction may not be used as a potable water supply when the drinking water standard is exceeded.

\subsection{Conceptual Model}

Water-level contours indicate that groundwater generally flows from west to east across the 400 Area. In addition, nitrate and tritium plumes, which originate in the 200 East Area, indicate that groundwater flows toward the east to southeast. The tritium plume is detected in the 400 Area water-supply wells, as discussed above. Tritium levels are lower in the vicinity of the 400 Area process ponds as a result of dilution effects. However, nitrate levels are currently elevated in the vicinity of the process ponds, apparently from the former disposal of sanitary sewage to a nearby lagoon. Since discharge of process water to the ponds is monitored under a state waste discharge permit, migration of contaminants from the ponds to the groundwater is not expected to be significant.

\subsection{Monitoring Program}

Monitoring well locations in the 400 Areas are presented in Figure 7.1. Upgradient well 699-8-17 was shown in Figure 4.8. Constituents monitored and sampling frequencies are presented in Appendix A. 


\subsection{Area}

The 300 Area is located along the Columbia River in the southeastern portion of the Hanford Site. This chapter also includes smaller areas to the north of the 300 Area that are included in the 300-FF-5 Operable Unit. These satellite areas to the north include the 618-10 and 618-11 burial grounds and the 316-4 crib.

\subsection{Background}

The 300 Area has been used for research-and-development and nuclear fuel-fabrication process activities associated with uranium fuel elements for nuclear reactors.

\subsubsection{Waste Sites, Discharges, and Groundwater Operable Units}

In the 300 Area, inactive waste sites known to have received liquid waste containing uranium and other known or suspected contaminants include the 316-5 process trenches and the 316-1 and 316-2 process ponds. These are the primary sites affecting groundwater contamination (Table 8.1). Other sites that received waste include sanitary septic tanks, trenches, and tile fields; ash pits; filter backwash ponds; and a number of burial grounds. The 300 Area also contained underground tanks for storing gasoline and diesel fuels.

The 316-5 process trenches require groundwater monitoring to meet RCRA requirements because the trenches are regulated as dangerous waste surface impoundments. The process trenches were modified as part of an expedited response action in 1991, and discharges to the trenches ceased in late 1994. The 316-1 and 316-2 process ponds, monitored to meet CERCLA requirements, received uraniumcontaminated wastewater until 1975 when the process trenches began receiving the wastewater. The storage tanks were monitored under the state's underground storage tank program in the early 1990s, but monitoring is no longer required by the state.

The 618-10 burial ground and adjacent 316-4 crib are located northwest of the 300 Area proper. The 618-11 burial ground is located even farther north, immediately northwest of Energy Northwest (see Figure 4.8). The burial grounds operated from 1954 to 1963 and received a variety of low- to highactivity radioactive waste, mostly composed of fission products with some plutonium-contaminated material (DOE 1996a). This waste was disposed in caissons and trenches and may have included liquid and solid waste forms.

The 316-4 crib began receiving uranium-bearing waste solutions in 1948 and continued to receive nitrate, hexone, and organic waste periodically through at least 1962. This site was investigated as part of a CERCLA limited field investigation for the 300-FF-2 Operable Unit (DOE 1996a). 
Table 8.1. Selected Waste Sites in the 300 Area

\begin{tabular}{|c|c|c|c|}
\hline Facility (period of use) & Waste Type & $\begin{array}{l}\text { Constituents of Interest } \\
\text { for Groundwater } \\
\text { Monitoring }\end{array}$ & $\begin{array}{l}\text { Type of Site } \\
\text { (monitoring plan } \\
\text { reference) }\end{array}$ \\
\hline \multicolumn{4}{|c|}{300 Area } \\
\hline $\begin{array}{l}316-5 \text { process trenches } \\
(1975-1994)\end{array}$ & $\begin{array}{l}\text { Variety of chemical and } \\
\text { uranium waste }\end{array}$ & $\begin{array}{l}\text { Uranium, trichloroethene, } \\
\text { cis-1,2-dichloroethene, } \\
\text { metals }\end{array}$ & $\begin{array}{l}\text { RCRA (Lindberg } \\
\text { and Chou 2001) }\end{array}$ \\
\hline $\begin{array}{l}316-1 \text { (south) and 316-2 } \\
\text { (north) process ponds } \\
(1940 \text { s-1975) }\end{array}$ & $\begin{array}{l}\text { Variety of chemical and } \\
\text { uranium waste }\end{array}$ & $\begin{array}{l}\text { Uranium, trichloroethene, } \\
\text { cis-1,2-dichloroethene }\end{array}$ & $\begin{array}{l}\text { Past-practice } \\
(300-F F-1 \text { and }-5 \\
\text { Operable Units, } \\
\text { ROD 1996b; DOE } \\
\text { 1996b) }\end{array}$ \\
\hline $\begin{array}{l}\text { 316-3 disposal trenches } \\
\text { (307 trenches) (1953-1963) }\end{array}$ & $\begin{array}{l}\text { Process waste including } \\
\text { uranium, plutonium, and beta } \\
\text { emitters }\end{array}$ & Uranium, strontium-90 & $\begin{array}{l}\text { Past-practice } \\
\text { (300-FF-2 Operable } \\
\text { Unit) }\end{array}$ \\
\hline \multicolumn{4}{|c|}{ 300-FF-5 Operable Unit Satellite Areas } \\
\hline $\begin{array}{l}618-10 \text { and }-11 \text { burial } \\
\text { grounds and } 316-4 \text { crib } \\
(1948-1962)\end{array}$ & $\begin{array}{l}\text { Low- to high-activity } \\
\text { radioactive waste }\end{array}$ & $\begin{array}{l}\text { Tritium, nitrate, hexone, } \\
\text { organic waste }\end{array}$ & $\begin{array}{l}\text { Past-practice } \\
\text { (300-FF-2 and } \\
\text { 300-FF-5 Operable } \\
\text { Units; DOE } 1996 b^{a}\end{array}$ \\
\hline \multicolumn{4}{|c|}{$\begin{array}{l}\text { (a) Plan being revised to include 618-10 and 618-11 burial grounds (groundwater beneath 300-FF-2 Operable } \\
\text { Unit). }\end{array}$} \\
\hline
\end{tabular}

\subsubsection{Groundwater Monitoring Requirements and History}

Extensive groundwater monitoring has been conducted in the 300 Area as far back as 1975, when the 316-5 process trenches replaced the 316-1 and 316-2 process ponds as the main facility for disposal of uranium-contaminated wastewater. The earliest major study on groundwater contamination in the 300 Area was in 1977 (Lindberg and Bond 1979). A site-specific program of groundwater monitoring of the 300 Area has been conducted since 1977. In 1985, interim status groundwater monitoring of the process trenches was initiated under RCRA, which required additional wells to be installed (Schalla et al. 1988). The RCRA program went into final-status groundwater monitoring in 1996 (Lindberg et al. 1995) and currently is in a corrective action program to determine if contaminants of concern (uranium and volatile organics) are naturally attenuating as expected by the 300-FF-5 record of decision (ROD 1996b). In response to the Tri-Party Agreement (Ecology et al. 1998), CERCLA activities were initiated in the early 1990s and included additional groundwater monitoring. An expedited response action was implemented in 1991 to remove sources of contamination and resulted in lower contaminant concentrations in groundwater downgradient from the process trenches. An interim remedial action required continued groundwater monitoring of contaminants in the 300 Area (ROD 1996b).

In 1993, DOE issued a proposal for an expedited response action for the 618-11 burial ground (DOE 1993). One well was installed in 1995 to support this action. In January 1999, a groundwater sample from this well was analyzed for tritium for the first time. The tritium concentration was 1.8 million 
pCi/L, much higher than surrounding wells. Subsequent samples confirmed the high result and indicated that the burial ground was the source of tritium. An additional groundwater investigation is currently underway, and the 618-11 burial ground and other waste sites nearby have been included in the 300-FF-2 and 300-FF-5 Operable Units (EPA 2000).

\subsection{Conceptual Model}

Groundwater in the uppermost aquifer flows into the 300 Area from the northwest, west, and southwest. A tritium plume derived from past wastewater disposal in the 200 East Area extends to the 300 Area. Tritium migrates across the northeastern portion of the 300 Area from the northwest and enters the Columbia River. In recent years, tritium levels have generally been steady with time in and north of the 300 Area. The southward migration of tritium is limited because of recharge patterns (see Section 9.2).

In the 300 Area, wastewater effluent, containing uranium and chlorinated solvent compounds, percolated through the soil from leaking process trenches and ponds for $\sim 50$ years. These constituents were driven down through the soil in the vadose zone beneath the waste sites by subsequent effluent discharges and natural recharge. As the constituents were carried downward, some were sorbed to sediment and trapped in soil moisture and some reached groundwater. Uranium in groundwater migrates toward and enters the Columbia River. The cis-dichloroethene plume is extremely limited in areal scope and is detected at levels above the drinking water standard $(70 \mu \mathrm{g} / \mathrm{L})$ at only one well, which is screened at the base of the uppermost aquifer. Trichloroethene is detected in the upper portion of the unconfined aquifer at concentrations below the drinking water standard $(5 \mu \mathrm{g} / \mathrm{L})$ and has two sources: (1) from a source offsite to the southwest and (2) from the 300 Area wastewater effluent.

Uranium concentrations in groundwater fluctuate in response to river-stage changes. As the river stage rises, groundwater near the river rises into a portion of the vadose zone. As a result, uranium is desorbed from the sediment and mobilized, temporarily increasing the uranium concentrations in groundwater. As the groundwater levels drop, uranium concentrations decrease because of the high mobility of uranium in groundwater and because the thickness of the saturated sediment from which uranium desorbs decreases.

The highest concentrations of chlorinated solvent compounds generally are found in the deeper portion of the unconfined aquifer beneath the process trenches and ponds. These higher concentrations have been found in the upper portion of the unconfined aquifer for brief periods (e.g., tetrachloroethene in 1998) and at lower concentrations for longer periods. Two conceptual model hypotheses have been suggested for the deeper occurrences. One hypothesis is that dissolved chlorinated compounds in groundwater were transported by a downward vertical hydraulic gradient created when discharged effluent to the ponds and trenches recharged the aquifer. This hypothesis requires a very low groundwater flow rate in the lower portions of the unconfined aquifer because these dissolved compounds are very mobile. The second hypothesis is that an immiscible phase that is denser than water was driven to the bottom of the unconfined aquifer by density (or the high downward vertical hydraulic gradient mentioned earlier) and rested on top of the silty clay unit that forms the base of the unconfined aquifer. A portion of the dense 
phase would then dissolve into the aqueous phase with time. This hypothesis is supported by the apparent natural degradation product, cis-dichloroethene, following trichloroethene that was observed in deeper 300 Area wells.

The 618-10 burial ground and the 316-4 crib have contaminated groundwater locally with uranium and hydrocarbons. The 618-11 burial ground has contaminated the vadose zone and groundwater with high levels of tritium, but the contamination is only detected in a single well.

\subsection{Monitoring Program}

Wells, constituents, and frequencies for surveillance monitoring are listed in Appendix A. Well locations are shown in Figures 8.1 and 4.8. Sampling is coordinated with RCRA (316-5 process trenches) and CERCLA (300-FF-5 Operable Unit). Most wells are sampled annually. 


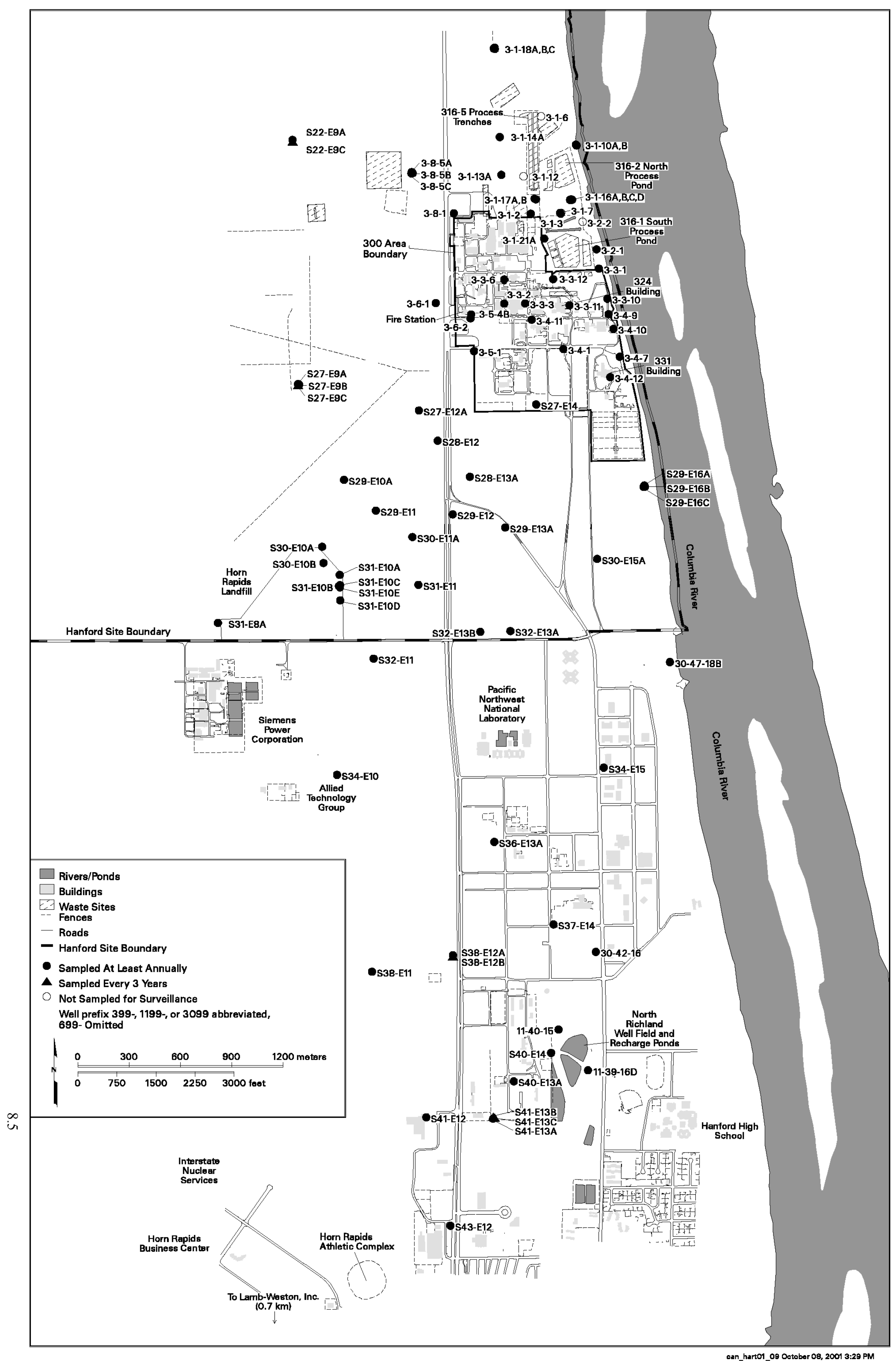

Figure 8.1. Groundwater Project Well Locations: 300 and Richland North Areas 


\subsection{Richland North Area}

The Richland North Area, though not formally defined, includes the former 1100 Area and the 3000 Area, part of the 600 Area adjacent to the 300 Area, and parts of nearby Richland.

\subsection{Background}

The Richland North Area consists of a variety of both onsite and offsite land uses, including municipal, industrial, and agricultural. Municipal and industrial facilities and agricultural activities in the Richland North Area influence groundwater. Offsite facilities of particular interest with respect to groundwater include the city of Richland's North Well Field and recharge basins, the ORV Park, Framatome ANP (formerly Siemens Power Corporation), the city of Richland's active Horn Rapids Landfill (formerly Richland Landfill), Lamb-Weston Richland Plant, Interstate Nuclear Services, and Allied Technology Group. Offsite agricultural irrigation influences groundwater over a wide area in the Richland North Area. Onsite facilities include DOE's inactive Horn Rapids Landfill in the 600 Area.

\subsubsection{Waste Sites, Discharges, and Groundwater Operable Units}

Waste sites in the Richland North Area include the inactive DOE Horn Rapids Landfill in the 600 Area and a number of disposal pits and underground storage tanks in the former 1100 Area. Groundwater associated with these waste sites is monitored to meet CERCLA requirements. The 1100-EM-1 Operable Unit record of decision (ROD 1993) required groundwater monitoring at a point of compliance downgradient from the inactive Horn Rapids Landfill. There are no DOE waste sites requiring RCRA groundwater monitoring in the Richland North Area. Table 9.1 lists the waste sites in the Richland North Area that have specific monitoring requirements and those sites that affected groundwater quality.

\subsubsection{Offsite Sources}

Probable sources of groundwater contamination that originated from the Richland North Area off the Hanford Site include Framatome ANP, agricultural irrigation, and Lamb-Weston Richland Plant. Framatome ANP is located adjacent to the Hanford Site boundary southwest of DOE's Horn Rapids Landfill, and a surface impoundment system at the site contributed to solvent and nitrate contamination in groundwater. Fertilizers applied to the agricultural fields upgradient (south) of Framatome ANP and potato-processing waste from the Lamb-Weston Richland Plant are probable sources of nitrate. The city of Richland's Horn Rapids Landfill is a source of organic solvent compound contamination of groundwater in the immediate vicinity of the landfill. This contamination is currently not impacting groundwater in the Richland North Area or the Hanford Site. Interstate Nuclear Services and Allied Technology Group are not known to contribute to groundwater contamination on the Hanford Site.

The city of Richland's North Well Field and recharge basins, located in the south-central part of the Richland North Area, are the primary influence on changes in groundwater elevation in the area. The well field serves as a secondary water supply for the city of Richland, and the basins recharge the 
Table 9.1. Selected Waste Sites in the Richland North Area

\begin{tabular}{|c|c|c|c|}
\hline Facility (period of use) & Waste Type & $\begin{array}{l}\text { Constituents of Interest } \\
\text { for Groundwater } \\
\text { Monitoring }\end{array}$ & $\begin{array}{l}\text { Type of Site } \\
\text { (monitoring plan } \\
\text { reference) }\end{array}$ \\
\hline $\begin{array}{l}\text { U.S. DOE's Horn Rapids } \\
\text { Landfill (1950s-1970) }\end{array}$ & $\begin{array}{l}\text { Office and construction waste, } \\
\text { asbestos, sewage sludge, fly } \\
\text { ash }\end{array}$ & $\begin{array}{l}\text { Trichloroethene, break- } \\
\text { down products of } \\
\text { trichloroethene (vinyl } \\
\text { chloride, 1,1-dichloro- } \\
\text { ethylene), chromium, } \\
\text { technetium-99, nitrate }\end{array}$ & $\begin{array}{l}\text { Past-practice } \\
\text { (1100-EM-1 Opera- } \\
\text { ble Unit; ROD 1993; } \\
\text { DOE 1995b) }\end{array}$ \\
\hline $\begin{array}{l}\text { Framatome ANP (formerly } \\
\text { Siemens Power Corpora- } \\
\text { tion) process lagoons } \\
\text { (offsite) (1971-present) }\end{array}$ & $\begin{array}{l}\text { Ammonia, fluoride, nitrate, } \\
\text { radionuclides (primarily } \\
\text { uranium) }\end{array}$ & Trichloroethene, nitrate & $\begin{array}{l}\text { Active RCRA; } \\
\text { Siemens (1996) }\end{array}$ \\
\hline Lamb-Weston (offsite) & Potato-processing waste & Nitrate & Active \\
\hline Agriculture (offsite) & Fertilizers & Nitrate & Active \\
\hline
\end{tabular}

unconfined aquifer with Columbia River water. The net recharge causes a groundwater mound to form in this area and decreases nitrate levels in groundwater to less than ambient.

Irrigation applied to agricultural fields contributes to groundwater recharge during the growing season. As a result, this contributes to groundwater flow to the northeast, east, and southeast.

\subsubsection{Groundwater Monitoring Requirements and History}

Groundwater well installation and monitoring began in the 1100 Area in 1988 after limited groundwater sampling in 1986 revealed low levels of contaminants (DOE 1990). A study was conducted in 1989-1992 and included well installation and groundwater monitoring to determine the nature and extent of groundwater contamination in the 1100 Area (DOE 1992). In 1993, continued and expanded groundwater monitoring in the 1100 Area was required (ROD 1993). In response to the record of decision, additional well installation and monitoring were implemented at U.S. DOE's inactive Horn Rapids Landfill (DOE 1995b). The ROD required the monitoring of trichloroethene in groundwater downgradient of U.S. DOE's inactive Horn Rapids Landfill. The ROD also required monitoring of trichloroethene breakdown products and nitrate. The monitoring of nitrate was needed because its concentrations were above the maximum contaminant levels for nitrate. A five-year review was conducted by EPA in 2001 and no groundwater monitoring changes were required at DOE's inactive Horn Rapids Landfill.

The surface impoundment system at Framatome ANP consists of six lagoons, which are regulated under the Revised Code of Washington, Title 70, Chapter 105 (Siemens Power Corporation 1997). The lagoons no longer receive liquid waste, however the lagoons still contain liquid waste from disposal in the past. Framatome ANP has monitored groundwater at their facility since 1994 to meet the requirements of RCRA interim status facilities. 


\subsection{Conceptual Model}

A tritium plume from past wastewater disposal in the 200 East Area extends to the southeastern Hanford Site, and wells in Richland North are monitored for tritium. However, the southward migration of tritium is limited because of the following factors:

- Groundwater is recharged by the Yakima River, and flows generally from southwest to northeast, and discharges to the Columbia River.

- Recharge from agricultural irrigation and an unlined artificial pond at the ORV Park between the Yakima River and the former 1100 Area contributes to eastward groundwater flow.

- Net recharge at the city of Richland's North Well Field has resulted in a groundwater mound that directs groundwater flow outward, including a component to the north.

A nitrate plume is migrating through the Richland North Area from the southwest toward the Columbia River. This area also contains a trichloroethene plume. Nitrate contamination is the result of offsite industrial and agricultural uses. Wastewater effluent containing ammonia was discharged in the past to lagoons at Framatome ANP. Effluent has apparently leaked to the underlying soil from the lagoons, and some of the ammonia reached groundwater. Under aerobic conditions, the ammonia degrades relatively quickly to nitrate, which is highly mobile in groundwater. In agricultural areas to the southwest, fertilizers containing nitrate are applied during the growing season. As irrigation is applied, the dissolved nitrate is carried down through the soil and is taken up by crops in the root zone. However, some of the nitrate is carried below the root zone by recharge of excess irrigation and reaches groundwater.

Trichloroethene contamination is suspected to be the result of offsite industrial solvent use at Framatome ANP. Solvents were used during installation, cleaning, and repairing of lagoon liners over a 10-year period between 1978 and 1988. Excess solvents entered the soil by spillage and were driven down into the vadose zone and reached groundwater, which is very shallow in this area. On reaching groundwater, trichloroethene is very mobile and formed a localized plume that migrated downgradient to the northeast across DOE's Horn Rapids Landfill. The highest concentrations were found near Framatome ANP and DOE's Horn Rapids Landfill. Trichloroethene concentrations were measured as high as $420 \mu \mathrm{g} / \mathrm{L}$ in the late $1980 \mathrm{~s}$, but decreased to less than $10 \mu \mathrm{g} / \mathrm{L}$ by the late $1990 \mathrm{~s}$. One hypothesis has been suggested that natural attenuation may have reduced the mass of the trichloroethene in groundwater. Natural attenuation in groundwater can occur by volatilization through passive pumping and biodegradation. Measurable trichloroethene concentrations were observed in soil gas in vicinity of DOE's inactive Horn Rapids Landfill (Evans 1989). In fiscal year 2001, all wells showed trichloroethene concentrations below the maximum contaminant level of $5 \mu \mathrm{g} / \mathrm{L}$. 


\subsection{Monitoring Program}

Wells, constituents, and sampling frequencies are listed in Appendix A. Well locations are shown in Figure 8.1. One objective is to monitor the extent of groundwater contamination in the Richland North Area to ensure that contaminants have not migrated offsite and have not affected wells in the city of Richland. This requires intensive monitoring near the leading edges of the plumes, in areas along the site boundary, and in areas where concentrations are low. Monitoring in areas where levels are low provides a baseline from which to determine concentration changes and, thus, early detection of offsite migration. The monitoring network includes wells completed in the deeper part of the unconfined aquifer. These wells are sampled every 3 years for low-level tritium analyses. An enrichment technique is used to measure tritium at lower detection limits $(\sim 10 \mathrm{pCi} / \mathrm{L})$ than provided by the standard method.

Another objective of monitoring the Richland North Area is to define plumes that have migrated onto the site from offsite sources. This monitoring is needed to show impacts to onsite groundwater and to show that groundwater contamination attributed to these plumes is not derived from onsite waste sites. 


\subsection{Area, Offsite, and Confined Aquifer Monitoring Activities}

\subsection{Background}

The 600 Area includes those parts of the Hanford Site not specifically included within the boundaries of the operational areas, though many of the 600 Area wells serve to monitor large contaminant plumes with their sources in the operational areas. Those wells are discussed in previous sections, especially Chapter 6, 200 East Area. This section largely addresses those parts of the 600 Area of the Hanford Site not included in the monitoring activities associated with the operational areas discussed in the other sections. The groundwater project monitors several waste sites located in the 600 Area, and monitors wells outside of Hanford influences to provide a basis for defining background groundwater chemistry. Specifically, the region addressed in this section is that portion of the 600 Area west of the 200 West, east and north of the Columbia River, and two landfills not covered in other sections of this plan. In addition, monitoring of chemistry and hydraulic head data is conducted within basalt-confined aquifers.

\subsubsection{Waste Sites}

The Central Landfill is located approximately 5.5 kilometers southeast of the 200 East Area and consists of the Solid Waste Landfill and the Nonradioactive Dangerous Waste Landfill, which are currently monitored separately under different regulations (Table 10.1). Agricultural activities in the area west of the Hanford Site contribute nitrate to the western portion of the 600 Area. Similar impacts of agriculture are recognized in the 600 Area north and east of the Columbia River.

The Gable Mountain Pond and B/C cribs were included in Chapter 6 because they were associated with 200 East Area operations. The 316-4 crib, and 618-10 and 618-11 burial grounds were included in Chapter 8 because they were associated with waste sources in the 300 Area.

\subsubsection{Groundwater Monitoring Requirements and History}

Monitoring of groundwater levels and contaminant concentrations in the 600 Area were initiated in the 1940s. Water-table maps of the unconfined aquifer have been prepared at various times since 1944. The primary monitoring objective is to obtain data needed to track major groundwater contaminant plumes across the site as required by the Atomic Energy Act of 1954 and its implementing orders. Wells not influenced by Hanford groundwater contamination are monitored to determine background groundwater quality. Wells across the Columbia River from Hanford Site operations are monitored to seek Hanford-derived contaminants that could be migrating offsite.

Additional wells were installed around the Central Landfill in 1986-1987 for RCRA (Nonradioactive Dangerous Waste Landfill) and Solid Waste Landfill monitoring. 
Table 10.1. Selected Waste Sites in the 600 Area

\begin{tabular}{||l|l|l|l||}
\hline Facility (period of use) & \multicolumn{1}{|c|}{ Waste Type } & $\begin{array}{l}\text { Constituents of Interest } \\
\text { for Groundwater } \\
\text { Monitoring }\end{array}$ & \multicolumn{1}{|c||}{$\begin{array}{c}\text { Type of Site } \\
\text { (monitoring plan } \\
\text { reference) }\end{array}$} \\
\hline \hline Solid Waste Landfill & $\begin{array}{l}\text { Solid waste, sewage, } \\
\text { garage wash water }\end{array}$ & Organics & $\begin{array}{l}\text { WAC permitted (Lindberg } \\
\text { and Chou 2000) }\end{array}$ \\
\hline $\begin{array}{l}\text { Nonradioactive } \\
\text { Dangerous Waste } \\
\text { Landfill }\end{array}$ & $\begin{array}{l}\text { Asbestos, laboratory } \\
\text { waste, solvents, } \\
\text { batteries, mercury }\end{array}$ & $\begin{array}{l}\text { Organics and specific } \\
\text { conductance }\end{array}$ & $\begin{array}{l}\text { RCRA (Lindberg and } \\
\text { Hartman 1999) }\end{array}$ \\
\hline
\end{tabular}

\subsection{Conceptual Model}

Groundwater levels indicate that flow directions in the 600 Area west of the 200 West Area are generally from west to east. This reflects natural recharge and irrigation input into the upper Cold Creek and Dry Creek Valleys (Hartman 2000). Significant contamination is not present in this area, though nitrate is present in certain wells. It is inferred that irrigation is the primary source of nitrate in this area.

Movement of tritium and nitrate plumes and measurement of water levels provide a basis for inferring the directions of groundwater flow in the 600 Area across the central and eastern portions of the Hanford Site. The tritium and nitrate plumes, which originate in the 200 East Area and pass beneath the Central Landfill, indicate that the principal direction of groundwater flow is toward the southeast and east.

The rate of groundwater flow beneath the landfill is estimated to be on the order of 1.2 to $1.8 \mathrm{~m} / \mathrm{d}$, based on site-specific hydrologic testing and the observed hydraulic gradients. However, groundwater velocity estimates based on tritium and nitrate concentrations and tracer test results indicate groundwater transport rates of 6 to $>30 \mathrm{~m} / \mathrm{d}$. The lack of a detectable head difference in two well pairs located at the Central Landfill indicates that the vertical gradient within the upper portion of the aquifer is negligible.

The Central Landfill appears to have had little impact on Hanford Site groundwater, owing to minimal disposal of liquids at this facility. Associated groundwater monitoring consists primarily of measurement of RCRA indicator parameters ( $\mathrm{pH}$, specific conductance, total organic carbon, and total organic halides), though minor (below maximum contaminant level) contamination with chlorinated hydrocarbons exists.

Monitoring of the chemistry and hydraulic head in the upper basalt-confined aquifer also is conducted at the Hanford Site. Hanford contaminants have been detected in a few wells monitoring this aquifer, but there is no evidence that contamination is moving offsite. The hydraulic gradient appears to be directed downward over most of the central portion of the Hanford Site, though the gradient is directed upward in the eastern portion of the site.

Water-level elevations north and east of the Columbia River are much greater than on the Hanford Site. The water-table elevation to the east of the Columbia River is currently 50 to 150 meters higher than on the Hanford Site. Groundwater flow in the unconfined aquifer system north and east of the Columbia 
River follows the bedrock structure and is toward the Columbia River. The water-table configuration in these areas largely reflects recharge from irrigation.

\subsection{Monitoring Program}

The monitoring network for the 600 Area was illustrated in Figure 4.8. Monitoring well locations for the Central Landfill are shown in Figure 10.1. Constituents monitored and sampling frequencies are presented in Appendix A.

Monitoring wells are maintained west of the 200 West Area and are sampled primarily for nitrate, which is probably related primarily to offsite agricultural activities.

There are six DOE wells located in the 600 Area north and east of the Columbia River, three of which have been used for contaminant monitoring. Currently, monitoring of contaminant concentrations in this area is limited to well 699-42-E9B (shown in Figure 4.8).

Wells in the basalt-confined aquifer are sampled every 3 years. Well locations are shown in Figure 10.2. 


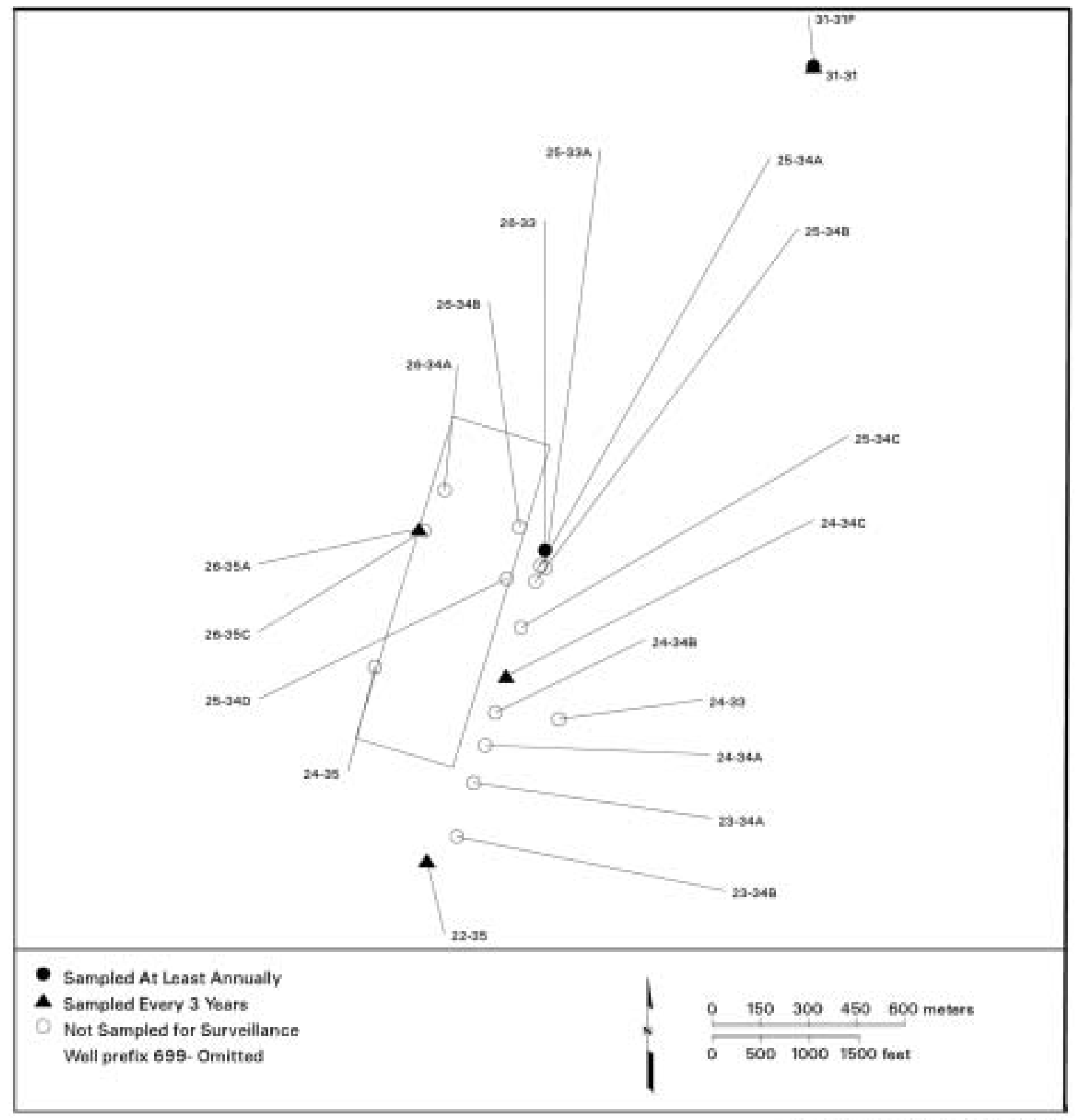

au hart asovy Septomber $20.19502 .04 \mathrm{PM}$

Figure 10.1. Groundwater Project Well Locations: Central Landfill 


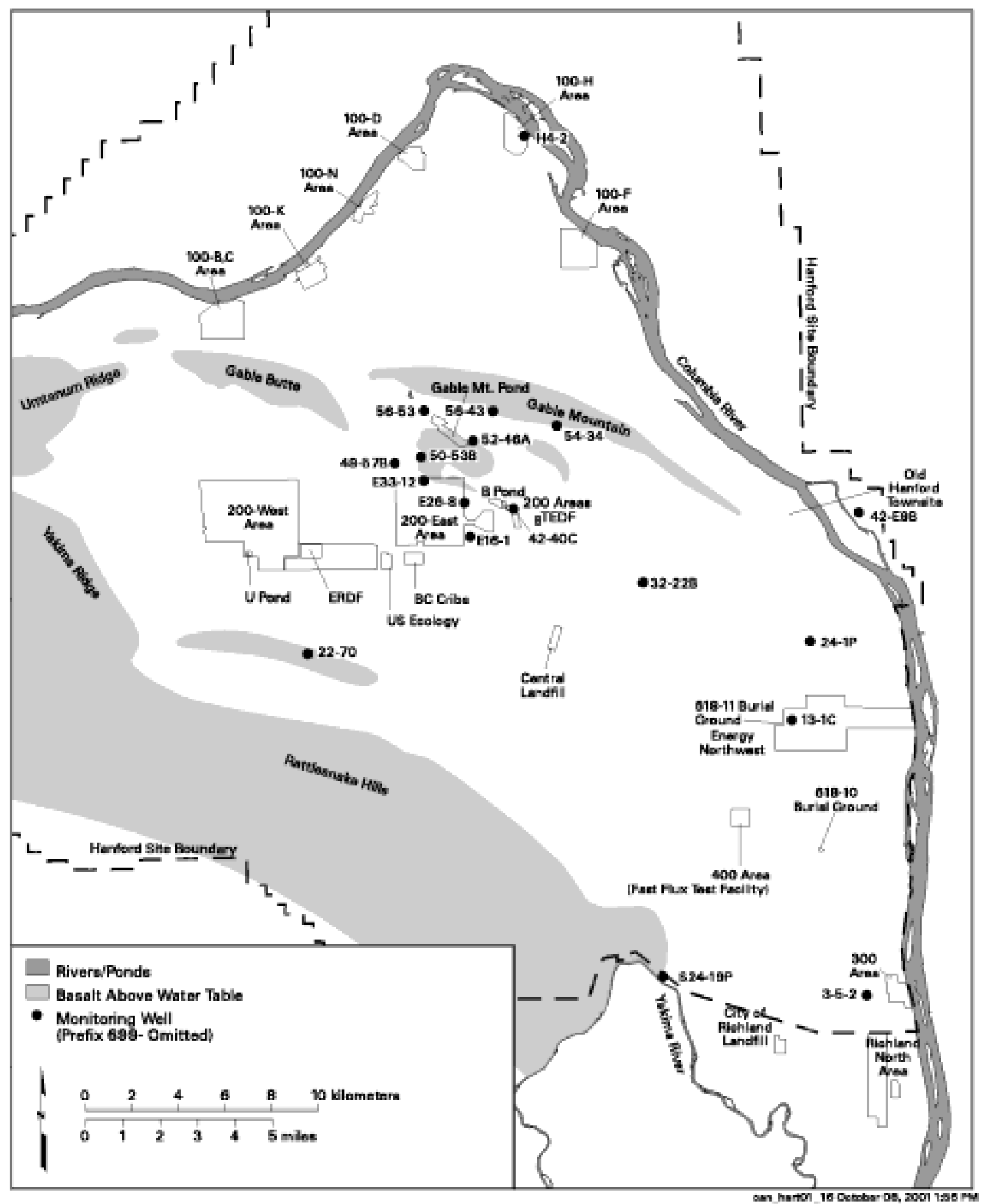

Figure 10.2. Groundwater Project Well Locations: Basalt-Confined Aquifer 


\subsection{Sampling and Analysis}

\subsection{Sampling and Analysis Protocol}

Employees and subcontractors of Pacific Northwest National Laboratory sample wells for the groundwater project. Procedures for groundwater sampling, documentation, sample preservation, shipment, and chain-of-custody requirements are described in PNNL or subcontractor manuals (currently WMNW procedures manual ES-SSPM-001 ${ }^{1}$ ) and in the quality assurance plan (ETD-012 $2^{2}$ latest revision). Samples generally are collected after three casing volumes of water have been purged from the well or after field parameters ( $\mathrm{pH}$, temperature, specific conductance, and turbidity) have stabilized. For routine groundwater samples, preservatives are added to the collection bottles before their use in the field. Samples to be analyzed for metals are usually filtered in the field so that results represent dissolved metals.

Procedures for field measurements are specified in the subcontractor's or manufacturer's manuals. Analytical methods are specified in contracts with laboratories, and most are standard methods from Test Methods for Evaluating Solid Wastes: Physical/Chemical Methods (EPA 1986). Alternative procedures meet the guidelines of SW-846, Chapter 10. Analytical methods are described in Hartman (2000).

\subsection{Quality Assurance and Quality Control}

The quality assurance and quality control practices used by the groundwater project ensure the reliability and validity of field and laboratory measurements conducted to support these programs. The primary components used to assess data quality are accuracy, precision, and detection. Representativeness, completeness, and comparability may also be used. These parameters are evaluated through laboratory quality control checks (e.g., matrix spikes, laboratory blanks), replicate sampling and analysis, analysis of blind samples and blanks, and interlaboratory comparisons. Acceptance criteria have been established for each of these parameters. When a parameter is outside the criteria, corrective actions are taken to prevent a future occurrence. Quality control practices for the groundwater project and results for fiscal year 2000 are described in Hartman et al. (2001, Appendix B).

A scientist familiar with the hydrogeology of a particular location of a site or region reviews new data every two weeks. Staff conduct a more formal review quarterly according to a Pacific Northwest National Laboratory procedure to ensure the data are complete and representative. The review includes verification of the data in the Hanford Environmental Information System (HEIS) database, evaluation of data from field quality control samples (e.g., blanks, duplicates) and laboratory quality control samples. If the data review identifies suspect data, they are investigated to establish whether they reflect true

\footnotetext{
${ }^{1}$ Available from Waste Management Technical Services, Inc., Northwest Operations, Richland, Washington.

${ }^{2}$ Available from the Hanford Site Groundwater Monitoring Project, Pacific Northwest National Laboratory, Richland, Washington.
} 
conditions or an error, according to Pacific Northwest National Laboratory's "request for data review" procedure. Groundwater data associated with out-of-range quality control data or identified as suspect during the technical review are flagged in the database. 


\subsection{Water-Level Monitoring}

Water levels in the groundwater system are monitored on the Hanford Site primarily to help determine the direction and rate of groundwater flow. This information is used to interpret observed contaminant plume movements and to predict future plume movements. Other uses of water-level information include the identification of recharge and discharge areas, assessing the interaction between groundwater and surface water, assessing the interaction between aquifers or hydrogeologic units, calibration of groundwater flow models, assessing the impact of liquid effluent disposal practices on groundwater flow, and optimizing monitoring networks.

McDonald et al. (1999) provides a list of wells used for water-level measurements, criteria for their selection, hydrogeologic units monitored, and describes procedures used to collect the data. 


\subsection{Data Evaluation}

\subsection{Data Management}

Results of groundwater sampling and analysis are accessible in the HEIS database. Analytical results from all Hanford Site groundwater monitoring are stored in this common database, with the exception of some data collected for limited special projects that may not be directly comparable to standard data. The data are available to federal and state regulators for retrieval.

The HEIS programmers and HEIS data owners, including the groundwater project, ensure database integrity and data consistency through participation in the onsite HEIS technical advisory group and other ad hoc groups. The majority of data are loaded into the database from electronic files provided by the analytical laboratories under standard protocols. This minimizes data-entry errors and reduces the cost of data management.

As discussed in Section 11.2, a data validation and verification process results in flags and qualifiers based on quality control data and a technical review by a scientist. These flags are stored with the data in HEIS.

\subsection{Compliance Issues and Data Evaluation}

Data collected for the groundwater project are used to comply with a variety of requirements, including the Atomic Energy Act of 1954 (and associated DOE Orders), RCRA, CERCLA, and WAC permits. After data are validated and verified, the acceptable data are used to interpret groundwater conditions at the site. Interpretive techniques include:

- Hydrographs - graph water levels versus time to determine decreases, increases, seasonal, or manmade fluctuations in groundwater levels.

- Water-table maps - use water-table elevations from multiple wells to construct contour maps to estimate flow directions. Groundwater flow is assumed to be perpendicular to lines of equal potential.

- Trend plots - graph concentrations of chemical or radiological constituents versus time to determine increases, decreases, and fluctuations. May be used in tandem with hydrographs and/or water-table maps to determine if concentrations relate to changes in water level or in groundwater flow directions.

- Plume maps - map distributions of chemical or radiological constituents areally in the aquifer to determine extent of contamination. Changes in plume distribution over time aid in determining movement of plumes and direction of flow. 
- Contaminant ratios — can sometimes be used to distinguish between different sources of contamination.

- Concentration limits - contaminant concentrations are compared to drinking water standards, statistically-derived threshold values, or other concentration limits established in state or federal regulations or agreements (Table 13.1).

\subsection{Reporting}

Results of Hanford Site groundwater monitoring are reported annually (e.g., Hartman et al. 2001). That report presents contaminant-distribution maps, water-level maps, and concentration trend plots of contaminants and wells of interest and meets the annual reporting requirements of RCRA and DOE Orders. CERCLA activities, including groundwater remediation and monitoring, are summarized.

Table 13.1. Compliance Issues and Methods of Evaluation

\begin{tabular}{||l|l||}
\hline \multicolumn{1}{|c|}{ Requirement } & \multicolumn{1}{c||}{ Evaluation } \\
\hline \hline DOE Order 5400.1 & $\begin{array}{l}\text { Compare groundwater concentrations to drinking water standards, derived } \\
\text { concentration guides, and historical trends. Produce maps of contaminant } \\
\text { distribution. }\end{array}$ \\
\hline RCRA interim status units & $\begin{array}{l}\text { Indicator evaluation - Compare average downgradient concentrations of } \\
\text { indicator parameters to background critical mean values. } \\
\text { Assessment - Evaluate rate and extent of contamination (methods } \\
\text { described in site-specific monitoring plans). }\end{array}$ \\
\hline RCRA final status units & $\begin{array}{l}\text { Detection - Compare downgradient concentrations of contaminants of } \\
\text { interest to baseline concentrations. } \\
\text { Compliance - Compare downgradient concentrations to background, } \\
\text { maximum concentration limits, or alternate concentration limits (methods } \\
\text { described in site-specific monitoring plans and site permit). } \\
\text { Corrective action - Track progress of cleanup and compare downgradient } \\
\text { concentrations of constituents to background, maximum concentration } \\
\text { limits, or alternate concentration limits (methods described in site-specific } \\
\text { monitoring plans and site permit). }\end{array}$ \\
\hline $\begin{array}{l}\text { WAC-permitted units } \\
\text { (216 permits) }\end{array}$ & Compare to conditions of permit. \\
\hline assessment monitoring) & $\begin{array}{l}\text { Compare concentrations to levels defined in record of decision, interim } \\
\text { records of decision, or other agreements. }\end{array}$ \\
\hline \hline
\end{tabular}


Certain conditions require reporting to DOE as unusual occurrences or off-normal events (DOE Order 232.1-1A). Those applicable to groundwater monitoring results include detection of contamination at the following levels:

- levels exceeding the derived concentration guide for a radionuclide in areas where this level has not previously been exceeded

- levels exceeding ten times the maximum contaminant level for hazardous constituents in areas where this level has not previously been exceeded

- levels above the drinking water standard or maximum contaminant level in areas where these levels have not previously been exceeded.

More stringent levels are set for areas adjacent to the Richland well field and/or south of Horn Rapids Road:

- $50 \%$ of the drinking water standard or maximum contaminant level for Hanford-derived contaminants, except for iodine-129 (maximum contaminant level is the detection limit) and tritium (10\% of the drinking water standard in the vicinity of the Richland well field).

An occurrence report also is also required if a RCRA groundwater assessment determines a facility has contaminated groundwater.

Reporting requirements for WAC-permitted facilities are described in their permits. 


\subsection{References}

Airhart, S. P., J. V. Borghese, and S. Dudziak. 1990. Interim-Status Ground Water Monitoring Plan for the 216-S-10 Pond and Ditch. WHC-SD-EN-AP-018, prepared by Pacific Northwest Laboratory for Westinghouse Hanford Company, Richland, Washington.

Atomic Energy Act of 1954, as amended, Ch. 1073, 68 Stat. 919, 42 USC 2011 et seq.

Barnett, D. B., J. S. Schmid, S. S. Lowe, W. L. Allen, N. A. Ballantyne, C. H. Dohrer, M. J. Hartman, F. N. Hodges, D. G. Horton, V. G. Johnson, K. J. Lueck, D. J. Ortiz, A. J. Knepp, B. H. Ford, S. P. Hope, D. K. Tyler, R. D. Hildebrand, D. E. Olson, R. E. Peterson, G. L. Kasza, D. A. Myers, S. P. Luttrell, P. D. Thorne, and K. R. Moser. 1995. Hanford Site Ground-Water Protection Management Plan. DOE/RL-89-12, Rev. 2, U.S. Department of Energy, Richland Operations Office, Richland, Washington.

Barnett, D. B. 2000. Groundwater Monitoring and Tritium-Tracking Plan for the 200 Area StateApproved Land Disposal Site. PNNL-13121, Pacific Northwest National Laboratory, Richland, Washington.

Borghese, J. V., M. J. Hartman, S. P. Luttrell, C. J. Perkins, J. P. Boric, and S. C. Tidal. 1996. 100-N Pilot Project: Proposed Consolidated Groundwater Monitoring Program. HI-00725, Bechtel Hanford, Inc., Richland, Washington.

CERCLA - Comprehensive Environmental Response, Compensation, and Liability Act of 1980, as amended, Public Law 96-510, 94 Stat. 2767, 42 USC 9601 et seq.

DOE. 1990. Phase 1 Remedial Investigation Report for the Hanford Site 1100-EM-1 Operable Unit. DOE/RL-90-18, U.S. Department of Energy, Richland Operations Office, Richland, Washington.

DOE. 1992. Final Remedial Investigation Study - Environmental Assessment Report for the 1100-EM-1 Operable Unit, Hanford. DOE/RL-92-67, Draft B, U.S. Department of Energy, Richland Operations Office, Richland, Washington.

DOE. 1993. 618-11 Burial Ground Expedited Response Action Proposal. DOE/RL-93-49, U.S. Department of Energy, Richland Operations Office, Richland, Washington.

DOE. 1995a. Hanford Sitewide Groundwater Remediation Strategy. DOE/RL-94-95, Rev. 1, U.S. Department of Energy, Richland Operations Office, Richland, Washington.

DOE. 1995b. Additional Monitoring Well Installation and Field Sampling Plan for Continued Groundwater Monitoring at the Horn Rapids Landfill. DOE/RL-95-50, prepared by the Department of the Army, Walla Walla District, Corps of Engineers, Walla Walla, Washington for the U.S. Department of Energy, Richland Operations Office, Richland, Washington. 
DOE. 1996a. Limited Field Investigation Report for the 300-FF-2 Operable Unit. DOE/RL-96-42, U.S. Department of Energy, Richland Operations Office, Richland, Washington.

DOE. 1996b. Operation and Maintenance Plan for the 300-FF-5 Operable Unit. DOE/RL-95-73, U.S. Department of Energy, Richland Operations Office, Richland, Washington.

DOE. 1997a. Interim Action Monitoring Plan for the 100-HR-3 and 100-KR-4 Operable Units. DOE/RL-96-90, prepared by CH2M HILL Hanford, Inc. for U.S. Department of Energy, Richland Operations Office, Richland, Washington.

DOE. 1997b. 200-UP-1 Groundwater Remedial Design/Remedial Action Work Plan. DOE/RL-97-36, Rev. 2, U.S. Department of Energy, Richland Operations Office, Richland, Washington.

DOE. 1997c. RCRA Corrective Measure Study for the 200-PO-1 Operable Unit. DOE/RL-96-66, U.S. Department of Energy, Richland Operations Office, Richland, Washington.

DOE. 2000. Environmental Monitoring Plan United State Department of Energy Richland Operations Office. DOE/RL-91-50, Rev. 3, U.S. Department of Energy, Richland, Washington.

DOE. 2001. Remedial Design Report/Remedial Action Work Plan for the 100-NR-2 Operable Unit. DOE/RL-2001-27, Decisional Draft, U.S. Department of Energy, Richland, Washington.

DOE Order 232.1. Occurrence Reporting and Processing of Operations Information. U.S. Department of Energy, Washington, D.C.

DOE Order 5400.1. General Environmental Protection Program. U.S. Department of Energy, Washington, D.C.

Ecology - Washington State Department of Ecology, U.S. Environmental Protection Agency, and U.S. Department of Energy. 1998. Hanford Federal Facility Agreement and Consent Order. Document No. 89-10, Rev. 5 (The Tri-Party Agreement), Olympia, Washington.

EPA. 1986a. Test Methods for Evaluating Solid Wastes: Physical/Chemical Methods, SW-846, 3rd Edition. U.S. Environmental Protection Agency, Office of Solid Waste and Emergency Response, Washington, D.C.

EPA. 2000. Explanation of Significant Difference for the 300-FF-5 Record of Decision, June 2000. U.S. Environmental Protection Agency, Region 10; and U.S. Department of Energy, Richland Operations Office, Richland, Washington.

Evans, J. C. 1989. 1100-EM-1 Soil Gas Survey Final Report. WHC-MR-0072, Westinghouse Hanford Company, Richland, Washington. 
Ford, B. H. 1996. Description of Work for Routine Groundwater Sampling at the Environmental Restoration Disposal Facility. BHI-00873, Bechtel Hanford, Inc., Richland, Washington.

Freeman-Pollard, J. R. 1996. 200-ZP-1 IRM Phase II and III Remedial Design Report. DOE/RL-96-07, Rev. 1. U.S. Department of Energy, Richland Operations Office, Richland, Washington.

Hartman, M. J. 1996. Groundwater Monitoring Plan for the 1301-N, 1325-N, and 1324-N/NA Sites. WHC-SD-EN-AP-038, Rev. 2, Westinghouse Hanford Company, Richland, Washington.

Hartman, M. J. 1997. Groundwater Monitoring Plan for the 183-H Solar Evaporation Basins. PNNL-11573, Pacific Northwest National Laboratory, Richland, Washington.

Hartman, M. J. (ed.). 2000. Hanford Site Groundwater Monitoring: Setting, Sources, and Methods. PNNL-13080, Pacific Northwest National Laboratory, Richland, Washington.

Hartman, M. J., P. E. Dresel, J. W. Lindberg, D. R. Newcomer, and E. C. Thornton. 2000. Integrated Monitoring Plan for the Hanford Groundwater Monitoring Project. PNNL-11989, Rev. 2, Pacific Northwest National Laboratory, Richland, Washington.

Hartman, M.J., L.F. Morasch, and W.D. Webber (eds.). 2001. Hanford Site Groundwater Monitoring for Fiscal Year 2000. PNNL-13404, Pacific Northwest National Laboratory, Richland, Washington.

Hodges, F.N. and C.J. Chou. 2000. Groundwater Quality Assessment Plan for Single-Shell Tank Waste Management Area $U$ at the Hanford Site. PNNL-13185, Pacific Northwest National Laboratory, Richland, Washington.

Horton D.G. and S. M. Narbutovskih. 2001. RCRA Groundwater Monitoring Plan for Single-Shell Tank Waste Management Area C at the Hanford Site. PNNL-13024, Pacific Northwest National Laboratory, Richland, Washington.

Jensen, E. J., M. A. Chamness, S. M. Goodwin, S. H. Hall, and D. R. Newcomer. 1990. Interim-Status Ground-Water Monitoring Plan for the 216-U-12 Crib. WHC-SD-EN-AP-019, prepared by Pacific Northwest Laboratory for Westinghouse Hanford Company, Richland, Washington.

Johnson, V. G. and C. J. Chou. 1999. RCRA Assessment Plan for Single-Shell Tank Waste Management Area S-SX at the Hanford Site. PNNL-12114, Pacific Northwest National Laboratory, Richland, Washington.

Johnson, V. G., C. J. Chou, and J. W. Lindberg. 1995. Groundwater Monitoring and Assessment Plan for the 100-K Area Fuel Storage Basins. WHC-SD-EN-AP-174, Westinghouse Hanford Company, Richland, Washington.

Last, G. V. and B. N. Bjornstad. 1989. Revised Ground-Water Monitoring Plan for the 200 Areas LowLevel Burial Grounds. WHC-SD-EN-AP-015, prepared by Pacific Northwest Laboratory for Westinghouse Hanford Company, Richland, Washington. 
Lindberg, J. W. 1997. Combination RCRA Groundwater Monitoring Plan for the 216-A-10, 216-A-36B, and 216-A-37-1 PUREX Cribs. PNNL-11523, Pacific Northwest National Laboratory, Richland, Washington.

Lindberg, J. W. and F. W. Bond. 1979. Geohydrology and Ground-Water Quality Beneath the 300 Area, Hanford Site, Washington. PNL-2949, Pacific Northwest Laboratory, Richland, Washington.

Lindberg, J. W. and M. J. Hartman. 1999. Groundwater Monitoring Plan for the Nonradioactive Dangerous Waste Landfill. PNNL-12227, Pacific Northwest National Laboratory, Richland, Washington.

Lindberg, J.W. and C.J. Chou. 2000. Groundwater Monitoring Plan for the Solid Waste Landfill. PNNL-13014, Pacific Northwest National Laboratory, Richland, Washington.

Lindberg, J.W. and C.J. Chou. 2001. Groundwater Monitoring Plan for the 300 Area Process Trenches. PNNL-13645, Pacific Northwest National Laboratory, Richland, Washington.

Lindberg, J. W., C. J. Chou, and V. G. Johnson. 1995. Groundwater Monitoring Plan for the 300 Area Process Trenches. WHC-SD-EN-AP-185, Westinghouse Hanford Company, Richland, Washington.

McDonald, J. P., M. A. Chamness, and D. R. Newcomer. 1999. Water-Level Monitoring Plan for the Hanford Groundwater Monitoring Project. PNNL-13021, Pacific Northwest National Laboratory, Richland, Washington.

Narbutovskih, S.M. 2000. Groundwater Quality Assessment Plan for Single-Shell Waste Management Area B-BX-BY at the Hanford Site. PNNL-13022, Pacific Northwest National Laboratory, Richland, Washington.

Narbutovskih, S.M. and D. G. Horton. 2001. RCRA Groundwater Monitoring Plan for Single-Shell Tank Waste Management Area A-AX at the Hanford Site. PNNL-13023, Pacific Northwest National Laboratory, Richland, Washington.

Peterson, R. E. and R. F. Raidl. 1996. Groundwater Monitoring Implementation Plan for the 100-BC-5, 100-KR-4, 100-HR-3, and 100-FR-3 Operable Units. BHI-00916, prepared by CH2M HILL Hanford, Inc. for Bechtel Hanford, Inc., Richland, Washington.

RCRA - Resource Conservation and Recovery Act of 1976, as amended, Public Law 94-580, 90 Stat. 2795, 42 USC 6901 et seq.

Record of Decision (ROD). 1993. Record of Decision, USDOE Hanford 1100 Area, Hanford Site, Richland, Washington (1100-EM-1, 1100-EM-2, 1100-EM-3 and 1100-IU-1 Operable Units). State of Washington Department of Ecology, U.S. Environmental Protection Agency, and U.S. Department of Energy, Richland Operations Office, Richland, Washington. 
Record of Decision (ROD). 1996a. Declaration of the Record of Decision, USDOE Hanford 100 Area, 100-HR-3 and 100-KR-4 Operable Units, Hanford Site, Benton County, Washington, April 1996. State of Washington Department of Ecology, U.S. Environmental Protection Agency, and U.S. Department of Energy, Richland Operations Office, Richland, Washington.

Record of Decision (ROD). 1996b. Declaration of the Record of Decision for the 300-FF-1 and 300-FF-5 Operable Units. State of Washington Department of Ecology, U.S. Environmental Protection Agency, and U.S. Department of Energy, Richland Operations Office, Richland, Washington.

Record of Decision (ROD). 1997. Declaration of the Record of Decision, U.S. DOE Hanford 200 Area, Hanford Site, Benton County, Washington (200-UP-1). State of Washington Department of Ecology, U.S. Environmental Protection Agency, and U.S. Department of Energy, Richland Operations Office, Richland, Washington.

Record of Decision (ROD). 1999. Amended Record of Decision, Decision Summary and Responsiveness Summary for the 100-HR-3 Operable Unit. U.S. Environmental Protection Agency, Region X, Seattle, Washington.

Revised Code of Washington, Title 70, Chapter 105, Hazardous Waste Management.

Schalla, R., R. L. Aaberg, D. J. Bates, J.V.M. Carlile, M. D. Freshley, T. L. Liikala, P. J. Mitchell, K. B. Olsen, and J. T. Rieger. 1988. Revised Ground-Water Monitoring Compliance Plan for the 300 Area Process Trenches. PNL-6671, Pacific Northwest Laboratory, Richland, Washington.

Schmid, J. S. 1990. Interim Status Groundwater Monitoring Plan for the 200 East Area Liquid Effluent Retention Facility. WHC-SD-EN-AP-024, Westinghouse Hanford Company, Richland, Washington.

Siemens Power Corporation. 1996. Groundwater Quality Assessment Plan, Surface Impoundment System. EMF-96-194, Richland, Washington.

Siemens Power Corporation. 1997. 1996 Annual RCRA Report, Groundwater Quality Assessment Program. EMF-1933, Richland, Washington.

Smith, R.M., F.N. Hodges, and B.A. Williams. 2001. Groundwater Quality Assessment Plan for SingleShell Tank Waste Management Area U. PNNL-13612, Pacific Northwest National Laboratory, Richland, Washington.

Sweeney, M. D. 1995a. Interim-Status Groundwater Monitoring Plan for the 216-B-63 Trench. WHC-SD-EN-AP-165, Westinghouse Hanford Company, Richland, Washington.

Sweeney, M. D. 1995b. Interim-Status Groundwater Monitoring Plan for the 216-B-3 Pond System. WHC-SD-EN-AP-013, Rev. 1, Westinghouse Hanford Company, Richland, Washington. 
Sweeney, M. D. 1999. Groundwater Monitoring Plan for the 216-A-29 Ditch. PNNL-13407, Pacific Northwest National Laboratory, Richland, Washington.

Sweeney, M. D. 2000a. Groundwater Sampling and Analysis Plan for the 100-BC-5 Operable Unit. PNNL-13326, Pacific Northwest National Laboratory, Richland, Washington.

Sweeney, M. D. 2000b. Groundwater Sampling and Analysis Plan for the 100-FR-3 Operable Unit. PNNL-13327, Pacific Northwest National Laboratory, Richland, Washington.

Weeks, D. C., G. K. Jager, W. J. McMahon, and B. H. Ford. 1996. Groundwater Protection Plan for the Environmental Restoration Disposal Facility. BHI-00079, Bechtel Hanford, Inc., Richland, Washington.

Williams, B. A. and C. J. Chou. 1993. Interim-Status Groundwater Quality Assessment Plan for the 216-U-12 Crib. WHC-SD-EN-AP-103, Westinghouse Hanford Company, Richland, Washington. 


\section{Appendix A}

Sampling Matrix for Hanford Site Groundwater Monitoring 


\section{Appendix A}

\section{Sampling Matrix for Hanford Site Groundwater Monitoring}

This appendix contains the integrated sampling and analysis matrix for the Hanford Site (Table A.1). The matrix was designed for use in fiscal year 2002, but also includes wells that will be sampled every 2 or 3 years (as discussed in Section 3.3 of the main text). The table lists primarily wells, but also includes seeps (shoreline springs) sampled for the Comprehensive Environmental Response, Compensation, and Liability Act of 1980 or the Surface Environmental Surveillance Project. The matrix includes well or seep names, program and project requesting the sample, sampling frequency, and constituents to be monitored. Additional details, such as schedule, analytical methods, etc., reside in a project database. The Hanford Groundwater Monitoring Project samples most of the wells, and other contractors sample wells for the State-Approved Land Disposal Site, the Treated Effluent Disposal Facility, and for assessment of pumpand-treat systems.

The environmental restoration project will sample aquifer sampling tubes in October and November 2001 (Table A.2). These are small diameter polyethylene tubes that have a screen at the lower end. The tubes were implanted in the aquifer through temporary steel casings. Staff attempted to install one tube near the bottom of the unconfined aquifer, one near the water table (at low river flow), and one at middepth. Table A. 2 is included here because the data from these samples are of interest to the groundwater project. Actual tube sites sampled may vary from this list, depending field conditions during fall 2001. More information on the sampling program is available in the Sampling and Analysis Plan for Aquifer Sampling Tubes (DOE 2000).

\section{KEY for TABLE A.1}

WELL: Wells are listed numerically by digit; e.g., "1199" precedes "199" and "699-299-4" precedes "699-3-45." Wells with a 199- prefix are in reactor areas, 299- in 200 Areas, 399- in 300 Area, 499- in 400 Area, 699- in 600-Area, and 1199- in 1100 Area. For 699-xx-yy wells, xx and yy designate Hanford north and west coordinates in thousands of feet from an origin in the southern part of the site. Multiple listings indicate that a well is used for more than one monitoring requirement and data are shared among users. Proposed new wells are listed with temporary designations PROJ-new-\#. Seeps, are designated with the prefixes SB, SK, etc.

Most of the wells monitor the uppermost aquifer. Wells that monitor deeper units are noted in the OTHER/COMMENTS field. 
PROG (program): This column indicates the requirements the well is being sampled for. The following gives the full spellouts:

CERC = Comprehensive Environmental Response, Compensation, and Liability Act of 1980

$\mathrm{DOH}=$ State of Washington Department of Health

ERC = Environmental Restoration Contractor (Bechtel Hanford, Inc.)

FFTF $=$ Fast Flux Test Facility (400 Area process ponds)

LTMC = Long-term monitoring, CERCLA

O\&M = Operations and Maintenance Contractor (Fluor Hanford, Inc.)

RCRA = Resource Conservation and Recovery Act of 1976

SESP = Sitewide Environmental Surveillance Project

SURV = sitewide surveillance (plume and trend tracking).

PROJ (project): This column gives the subsets of the programs listed above.

\begin{tabular}{|c|c|}
\hline Project Designation & Explanation \\
\hline $\begin{array}{l}100,200,300,400, \text { or } \\
600 \mathrm{DOH}\end{array}$ & $\begin{array}{l}\text { Department of Health monitoring in 100, 200, 300, 400, } \\
\text { and } 600 \text { Areas }\end{array}$ \\
\hline 100B & $100 \mathrm{~B} / \mathrm{C}$ Area and surrounding region \\
\hline 100BC5 & 100-BC-5 Operable Unit \\
\hline 100D & $100 \mathrm{D}$ Area and surrounding region \\
\hline $100 \mathrm{~F}$ & $100 \mathrm{~F}$ Area and surrounding region \\
\hline 100FR3 & 100-FR-3 Operable Unit \\
\hline $100 \mathrm{H}$ & $100 \mathrm{H}$ Area and surrounding region \\
\hline 100HR3 & 100-HR-3 interim action monitoring \\
\hline 100HR3 PT & $\begin{array}{l}\text { 100-HR-3 pump-and-treat operational monitoring. (Not } \\
\text { Hanford Groundwater Monitoring Project) }\end{array}$ \\
\hline $100 \mathrm{~K}$ & $100 \mathrm{~K}$ Area and surrounding region \\
\hline 100K Basin & 100 K Fuel Storage Basin monitoring \\
\hline $100 \mathrm{KR} 4$ & $100-\mathrm{KR}-4$ interim action monitoring \\
\hline 100KR4PT & $\begin{array}{l}\text { 100-KR-4 pump-and-treat operational monitoring. (Not } \\
\text { Hanford Groundwater Monitoring Project) }\end{array}$ \\
\hline $100 \mathrm{~N}$ & $100 \mathrm{~N}$ Area and surrounding region \\
\hline $100 \mathrm{NR} 2$ & 100-NR-2 interim action monitoring \\
\hline $1301 \mathrm{~N}$ & 1301-N liquid waste disposal facility \\
\hline $1324 \mathrm{~N}$ & $\begin{array}{l}\text { 1324-N surface impoundment and 1324-NA percolation } \\
\text { pond }\end{array}$ \\
\hline $1325 \mathrm{~N}$ & 1325-N liquid waste disposal facility \\
\hline
\end{tabular}


Project Designation

$183 \mathrm{H}$

200BP5

200UP1

200ZP1

200ZP1 PT

300

300-APT

300FF5

400

A-29

B-63

Basalt

BPOND

Central

East

ERDF

HRLF

ISRM

LERF

LLBG(1)

$\operatorname{LLBG}(2)$

LLBG(3)

LLBG(4)

NRDW

PUREX

$\mathrm{RCHN}$

S-10

SALDS

Spring Seep
Explanation

183-H solar evaporation basins

200-BP-5 Operable Unit

200-UP-1 interim action monitoring

200-ZP-1 interim action monitoring

200-ZP-1 pump-and-treat operational monitoring. (Not Hanford Groundwater Monitoring Project)

300 Area

300 Area process trenches (316-5)

300-FF-5 Operable Unit

400 Area

216-A-29 ditch

216-B-63 trench

Wells monitoring basalt-confined aquifers

216-B-3 pond

200-BP-5 Operable Unit (northwestern 200 East Area) and surrounding region

200-PO-1 Operable Unit (southeastern 200 East Area and downgradient region)

Environmental Restoration Disposal Facility

Horn Rapids Landfill

In Situ Redox Manipulation project

Liquid effluent retention facility

Low-level burial ground, Waste Management Area 1

Low-level burial ground, Waste Management Area 2

Low-level burial ground, Waste Management Area 3

Low-level burial ground, Waste Management Area 4

Nonradioactive Dangerous Waste Landfill

Plutonium-Uranium Extraction Plant waste facilities

Richland North Area

216-S-10 pond and ditch

State-Approved Land Disposal System (Not Hanford Groundwater Monitoring Project)

Riverbank seep site 
Project Designation

$\operatorname{SST}(\mathrm{A})$

$\operatorname{SST}(\mathrm{B})$

$\operatorname{SST}(C)$

$\mathrm{SST}(\mathrm{S})$ or $(\mathrm{SX})$

$\operatorname{SST}(\mathrm{T})$

SST(TX/TY)

$\operatorname{SST}(\mathrm{U})$

SWL

TEDF

$\mathrm{U}-12$

West
Explanation

Single-shell tanks, Waste Management Area A-AX

Single-shell tanks, Waste Management Area B-BX-BY

Single-shell tanks, Waste Management Area C

Single-shell tanks, Waste Management Area S-SX

Single-shell tanks, Waste Management Area T

Single-shell tanks, Waste Management Area TX-TY

Single-shell tanks, Waste Management Area U

Solid Waste Landfill

Treated Effluent Disposal Facility (Not Hanford

Groundwater Monitoring Project)

216-U-12 crib

200 West Area and surrounding region, including western Hanford Site

The next 21 columns give the most commonly analyzed constituents. Some constituents may be analyzed by several methods; however, those details are not specified in this plan and are included in the project database. The following abbreviations are used:

Cr6+ = hexavalent chromium

$\mathrm{DO}=$ dissolved oxygen

$\mathrm{I}-129=$ iodine- 129

$\mathrm{ICP}=$ metals by the inductively coupled-plasma method

Sr-90 = strontium-90 (or strontium-89 and -90 )

Tc-99 = technetium-99

$\mathrm{TDS}=$ total dissolved solids

TOC $=$ total organic carbon

TOX $=$ total organic halides

VOA $=$ volatile organic constituents

Letters in the constituents column indicate the frequency of sampling for that constituent:
$\mathrm{A}=$ annually
$\mathrm{B}=$ biennially (every two years)
$\mathrm{M}=$ monthly
$\mathrm{Q}=$ quarterly
$S$ = semiannually (twice each year).
$\mathrm{T}=$ triennially (every three years). 
A number after the frequency (e.g., S4) indicates the number of replicates collected (in this case, four replicates are collected semiannually). Unfiltered and filtered samples are denoted $\mathrm{u}$ and $\mathrm{f}$, respectively (samples are unfiltered unless otherwise noted).

OTHER/COMMENTS: This field includes the hydrologic unit monitored if other than the unconfined aquifer, the schedule year for sampling biennial or triennial constituents, and additional constituents not listed in the previous columns. Metals are listed by their standard abbreviations, followed by " $\mathrm{f}$ " if filtered. Other constituents are abbreviated as follows:
Amm = ammonium
$\mathrm{C} 14=$ carbon- 14
COD $=$ chemical oxygen demand
col $=$ coliform bacteria
$\mathrm{O} \& \mathrm{G}=$ oil and grease
$\mathrm{PCB}=$ polychlorinated biphenyl
Puis = isotopic plutonium
$\mathrm{TPH}=$ total petroleum hydrocarbons
Uiso $=$ isotopic uranium
$\mathrm{SO} 4=$ sulfate
$\mathrm{PCB}=$ polychlorinated biphenyls.

\section{NOTES:}

(a) Additional constituents: Filtered and unfiltered trace metals ( $\mathrm{As}, \mathrm{Ba}, \mathrm{Cr}, \mathrm{Pb}, \mathrm{Se}, \mathrm{Sn}, \mathrm{V}, \mathrm{Zn}$ ), nitrite/nitrate, radium, and carbon- 14 .

(b) McDonald et al. (1999).

\section{KEY FOR TABLE A.2}

Sample location name: Two different conventions have been used to name the locations where aquifer sampling tubes are installed. The first convention was used during the riverbed pore water sampling investigations conducted at $100 \mathrm{H}$ Area in spring 1995 (Hope and Peterson 1996a) and at $100 \mathrm{D} / \mathrm{DR}$ Area in fall 1995 (Hope and Peterson 1996b). An example for an aquifer sampling tube location is:

"DD-17-2." The first letter indicates a sampling tube that is driven into the aquifer. The second letter refers to the 100 D/DR Area. The number "17" refers to pore water transect 17 (see BHI references for location maps) and the number "2" indicates the depth of the sampling port, with "1" being the most shallow and "4" being the deepest. The second convention was established for the fall 1997 project to install aquifer sampling tubes along the Hanford Reach shoreline from the $100 \mathrm{~B} / \mathrm{C}$ Area downstream to the Hanford Townsite (Peterson et al. 1998). Temporary location names were created that represent the sequence of locations, progressing downstream, and a suffix that indicated the depth of the sampling port. For example, location "14-D" is the fourteenth location downstream of the upstream starting point. The suffix " $D$ " indicates the deepest port in the uppermost hydrologic unit at that location ("S" stands for the shallowest port, and "M" for the mid-depth port). 
HEIS well ID number: aquifer sampling tubes are assigned a unique code for tracking in the HEIS database.

Area: general location of sampling tube.

Field parameters such as specific conductance, $\mathrm{pH}$, temperature, turbidity, and dissolved oxygen are measured at the well head. On-site or off-site laboratory analyses are run for some constituents as indicated in the table.

\section{References}

CERCLA - Comprehensive Environmental Response, Compensation, and Liability Act of 1980, as amended, Public Law 96-510, 94 Stat. 2767, 42 USC 9601 et seq.

DOE. 2000. Sampling and Analysis Plan for Aquifer Sampling Tubes. DOE/RL-2000-59, U.S. Department of Energy, Richland, Washington.

Hope, S. J. and R. E. Peterson. 1996a. Pore Water Chromium Concentrations at 100-H Reactor Area Adjacent to Fall Chinook Salmon Spawning Habitat of the Hanford Reach, Columbia River. BHI-00345, Rev. 1, Bechtel Hanford, Inc., Richland, Washington.

Hope, S. J. and R. E. Peterson. 1996b. Chromium in River Substrate Pore Water and Adjacent Groundwater: 100-D/DR Area, Hanford Site, Washington. BHI-00778, CH2M HILL Hanford, Inc., for Bechtel Hanford, Inc., Richland, Washington.

Peterson, R. E., J. V. Borghese, and D. B. Erb. 1998. Aquifer Sampling Tube Completion Report: 100 Area and Hanford Townsite Shorelines. BHI-01153, CH2M HILL Hanford, Inc., for Bechtel Hanford, Inc., Richland, Washington.

RCRA - Resource Conservation and Recovery Act of 1976, as amended, Public Law 94-580, 90 Stat. 2795, 42 USC 6901 et seq. 
Table A.1. Integrated Sampling and Analysis Matrix for the Hanford Site

\begin{tabular}{|c|c|c|c|c|c|c|c|c|c|c|c|c|c|c|c|c|c|c|c|c|c|c|c|c|}
\hline WELL & PROG & PROJ & 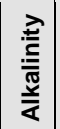 & $\frac{\frac{\pi}{0}}{\frac{0}{\alpha}}$ & $\frac{\mathscr{n}}{\frac{0}{\frac{5}{c}}}$ & 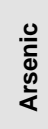 & 丞 & ț & 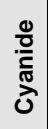 & 음 & 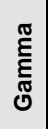 & $\begin{array}{l}0 \\
\infty \\
\infty \\
\text { వ } \\
\text { I }\end{array}$ & $\stackrel{\text { ని }}{\underline{I}}$ & $\underline{0}$ & $\begin{array}{l}\frac{\infty}{0} \\
\frac{\Phi}{0} \\
\frac{1}{\alpha}\end{array}$ & $\begin{array}{l}\text { के } \\
\frac{1}{\omega}\end{array}$ & $\begin{array}{l}\stackrel{8}{d} \\
\dot{0}\end{array}$ & $\stackrel{c}{0}$ & ષ & 암 & 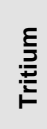 & 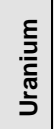 & §ీ & Other/comments \\
\hline 1199-39-16D & SURV & RCHN & A & A & A & & A & & & $Q$ & & & & Af & & & & & & & $\mathrm{Q}$ & & A & \\
\hline $1199-40-15$ & SURV & $\mathrm{RCHN}$ & & & & & & & & A & & & & & & & & & & & A & & & \\
\hline 199-B2-12 & LTMC & 100BC5 & & A & A & & A & & & & & & & Af & & A & & & & & A & & & \\
\hline 199-B2-12 & SURV & $100 \mathrm{~B}$ & $\mathrm{~T}$ & & $T$ & & & & & $\mathrm{~T}$ & & & & $\mathrm{Tf}$ & & & & & & & $T$ & & & FY02 \\
\hline 199-B2-13 & SURV & $100 \mathrm{~B}$ & A & & A & & & & & A & & & & Af & & & & & & & A & & & \\
\hline 199-B3-1 & LTMC & $100 \mathrm{BC} 5$ & & A & A & & A & & & & & & & Af & & A & & & & & A & & & \\
\hline 199-B3-46 & LTMC & $100 \mathrm{BC} 5$ & & A & A & & A & & & & & & & Af & & A & & & & & A & & & \\
\hline 199-B3-47 & LTMC & $100 \mathrm{BC} 5$ & & A & A & & A & Af & & & & & & Af & & A & & & & & A & & & \\
\hline 199-B4-2 & SURV & $100 \mathrm{~B}$ & A & & A & & & & & A & & & & Af & & & & & & & A & & & \\
\hline 199-B4-4 & LTMC & $100 \mathrm{BC} 5$ & & B & B & & B & & & & & & & $\mathrm{Bf}$ & & B & & & & & B & & & FY02 \\
\hline 199-B4-5 & LTMC & 100BC5 & & B & B & & B & & & & & & & $\mathrm{Bf}$ & & B & & & & & B & & & FY02 \\
\hline 199-B4-7 & LTMC & 100BC5 & & B & B & & B & & & & & & & $\mathrm{Bf}$ & & B & & & & & B & & & FY02 \\
\hline 199-B4-8 & SURV & $100 \mathrm{~B}$ & A & & A & & & & & A & & & & Af & & & & & & & & & & \\
\hline 199-B4-9 & SURV & $100 \mathrm{~B}$ & A & & A & & & & & & & & & Af & & A & & & & & A & & & \\
\hline 199-B5-1 & LTMC & 100BC5 & & A & A & & A & Af & & & & & & Af & & A & & & & & A & & & \\
\hline 199-B5-2 & LTMC & 100BC5 & & A & A & & A & & & & & & & Af & & A & & & & & A & & & \\
\hline 199-B8-6 & LTMC & 100BC5 & & B & B & & B & & & & & & & $\mathrm{Bf}$ & & $B$ & & & & & B & & & FY02 \\
\hline 199-B9-1 & SURV & $100 \mathrm{~B}$ & A & & A & & & & & A & & & & Af & & & & & & & A & & & \\
\hline 199-B9-2 & LTMC & 100BC5 & & B & B & & B & & & & & & & $\mathrm{Bf} / \mathrm{u}$ & & $B$ & & & & & B & & & FY02 \\
\hline 199-D2-6 & CERC & $100 \mathrm{HR} 3$ & & A & A & & A & Qf & & & & & & Af $/ \mathrm{u}$ & & & & & & & A & & & Q: SO4 \\
\hline 199-D2-6 & CERC & ISRM & & & A & & & Qf & & Q & & & & Af & & & & & & & & A & & Q:SO4 \\
\hline 199-D2-6 & SURV & 100D & A & & A & & & & & A & & & & Af & & & & & & & A & & & \\
\hline 199-D3-2 & CERC & 100HR3 & & A & A & & A & Qf & & & & & & Af/u & & & & & & & A & & & Q: SO4 \\
\hline 199-D3-2 & CERC & ISRM & & & A & & & Qf & & Q & & & & Af & & & & & & & & A & & Q:SO4 \\
\hline \begin{tabular}{|l|} 
199-D3-2 \\
\end{tabular} & SURV & $100 \mathrm{D}$ & A & & A & & & & & A & & & & Af & & & & & & & A & & & \\
\hline 199-D4-1 & CERC & ISRM & & & A & & & Qf & & $Q$ & & & & Af & & & & & & & & A & & Q:SO4 \\
\hline 199-D4-13 & CERC & 100HR3 & & A & A & & A & Qf & & & & & & $\mathrm{Af} / \mathrm{u}$ & & & & & & & A & & & Q:SO4 \\
\hline 199-D4-13 & SURV & $100 \mathrm{D}$ & A & & A & & & & & A & & & & Af & & & & & & & & & & \\
\hline 199-D4-14 & CERC & $100 \mathrm{HR} 3$ & & A & A & & A & Qf & & & & & & Af $/ \mathrm{u}$ & & & & & & & A & & & Q:SO4 \\
\hline
\end{tabular}




\begin{tabular}{|c|c|c|c|c|c|c|c|c|c|c|c|c|c|c|c|c|c|c|c|c|c|c|c|c|}
\hline WELL & PROG & PROJ & 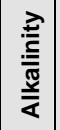 & $\frac{\frac{\pi}{2}}{\frac{2}{\alpha}}$ & $\begin{array}{l}\frac{n}{2} \\
\frac{0}{\frac{L}{L}}\end{array}$ & 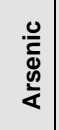 & 丞 & ثั๋ & $\begin{array}{l}\frac{0}{0} \\
\frac{\mathrm{J}}{\mathrm{J}} \\
\mathrm{J}\end{array}$ & 음 & $\begin{array}{l}\text { हू } \\
\text { हू } \\
\text { ઠॉ }\end{array}$ & $\begin{array}{l}0 \\
0 \\
\infty \\
\text { 오 }\end{array}$ & $\frac{\text { Tे }}{\mathbf{I}}$ & $\stackrel{0}{0}$ & $\begin{array}{l}\frac{0}{0} \\
\frac{5}{6} \\
\frac{5}{0}\end{array}$ & $\begin{array}{l}\text { के } \\
\frac{1}{\omega}\end{array}$ & $\begin{array}{c}\text { g. } \\
\dot{0}\end{array}$ & $\stackrel{\mathscr{P}}{\mathfrak{R}}$ & $\underset{ }{0}$ & 层 & $\underset{\underline{\underline{E}}}{\underline{\underline{E}}}$ & 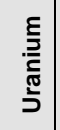 & §̊ & Other/comments \\
\hline 199-D4-14 & SURV & $100 \mathrm{D}$ & A & & A & & & & & A & & & & Af & & & & & & & & & & \\
\hline 199-D4-15 & CERC & 100HR3 & & A & A & & A & Qf & & & & & & $A f / u$ & & & & & & & A & & & Q:SO4 \\
\hline 199-D4-15 & CERC & ISRM & & & A & & & Qf & & $Q$ & & & & Af & & & & & & & & A & & Q:SO4 \\
\hline 199-D4-15 & SURV & $100 \mathrm{D}$ & $A$ & & A & & & & & A & & & & Af & & & & & & & & & & \\
\hline 199-D4-19 & CERC & 100HR3 & & $\mathrm{A}$ & $\mathrm{A}$ & & A & Qf & & & & & & $\mathrm{Af} / \mathrm{u}$ & & & & & & & A & & & Q:SO4 \\
\hline 199-D4-20 & CERC & 100HR3 & & A & A & & $A$ & Qf & & & & & & $\mathrm{Af} / \mathrm{u}$ & & & & & & & A & & & Q:SO4 \\
\hline \begin{tabular}{|l|}
$199-D 4-20$ \\
\end{tabular} & CERC & ISRM & & & A & & & Qf & & $Q$ & & & & Af & & & & & & & & A & & Q:SO4 \\
\hline 199-D4-22 & CERC & 100HR3 & & A & A & & A & Qf & & & & & & $\mathrm{Af} / \mathrm{u}$ & & & & & & & A & & & Q:SO4 \\
\hline 199-D4-22 & CERC & ISRM & & & A & & & Qf & & $Q$ & & & & Af & & & & & & & & A & & Q:SO4 \\
\hline 199-D4-22 & SURV & $100 \mathrm{D}$ & A & & A & & & Qf/u & & $Q$ & & & & $\mathrm{Af}$ & & & & & & & & & & \\
\hline 199-D4-23 & CERC & 100HR3 & & A & A & & A & Qf & & & & & & $\mathrm{Af} / \mathrm{u}$ & & & & & & & A & & & Q:SO4 \\
\hline 199-D4-23 & CERC & ISRM & & & A & & & Qf & & $Q$ & & & & Af & & & & & & & & A & & Q:SO4 \\
\hline 199-D4-23 & SURV & $100 \mathrm{D}$ & A & & A & & & Qf/u & & $Q$ & & & & Af & & & & & & & & & & \\
\hline 199-D4-26 & CERC & ISRM & & & $\mathrm{A}$ & & & Qf & & $Q$ & & & & Af & & & & & & & & A & & Q:SO4 \\
\hline 199-D4-31 & CERC & ISRM & & & A & & & Qf & & $Q$ & & & & Af & & & & & & & & A & & Q:SO4 \\
\hline 199-D4-32 & CERC & ISRM & & & $\mathrm{A}$ & & & Qf & & $Q$ & & & & Af & & & & & & & & A & & Q:SO4 \\
\hline 199-D4-36 & CERC & ISRM & & & A & & & Qf & & $Q$ & & & & Af & & & & & & & & A & & Q:SO4 \\
\hline 199-D4-38 & CERC & ISRM & & & A & & & Qf & & $Q$ & & & & Af & & & & & & & & A & & Q:SO4 \\
\hline 199-D4-39 & CERC & ISRM & & & A & & & Qf & & $Q$ & & & & Af & & & & & & & & A & & Q:SO4 \\
\hline 199-D4-4 & CERC & ISRM & & & A & & & Qf & & $Q$ & & & & Af & & & & & & & & A & & Q:SO4 \\
\hline 199-D4-4 & SURV & $100 \mathrm{D}$ & A & & A & & & Qf/u & & $Q$ & & & & Af & & & & & & & & & & \\
\hline 199-D4-48 & CERC & ISRM & & & $\mathrm{A}$ & & & Qf & & $Q$ & & & & Af & & & & & & & & A & & Q:SO4 \\
\hline 199-D4-5 & CERC & ISRM & & & A & & & Qf & & $Q$ & & & & Af & & & & & & & & A & & Q:SO4 \\
\hline 199-D4-5 & SURV & $100 \mathrm{D}$ & $\mathrm{A}$ & & A & & & Qf/u & & $Q$ & & & & Af & & & & & & & & & & \\
\hline 199-D4-6 & CERC & ISRM & & & A & & & Qf & & $Q$ & & & & Af & & & & & & & & $A$ & & Q:SO4 \\
\hline 199-D4-6 & SURV & $100 \mathrm{D}$ & A & & A & & & Qf/u & & $Q$ & & & & Af & & & & & & & & & & \\
\hline 199-D4-62 & CERC & ISRM & & & A & & & Qf & & $Q$ & & & & Af & & & & & & & & A & & Q:SO4 \\
\hline \begin{tabular}{|l|} 
199-D4-7 \\
\end{tabular} & CERC & ISRM & & & A & & & Qf & & $Q$ & & & & Af & & & & & & & & A & & Q:SO4 \\
\hline \begin{tabular}{|l|} 
199-D4-7 \\
\end{tabular} & SURV & $100 \mathrm{D}$ & A & & $\mathrm{A}$ & & & Qf/u & & $Q$ & & & & Af & & & & & & & & & & \\
\hline 199-D4-78 & CERC & ISRM & & & A & & & Qf & & $Q$ & & & & Af & & & & & & & & A & & Q:SO4 \\
\hline 199-D4-83 & CERC & ISRM & & & $A$ & & & Qf & & $Q$ & & & & Af & & & & & & & & $A$ & & Q:SO4 \\
\hline
\end{tabular}




\begin{tabular}{|c|c|c|c|c|c|c|c|c|c|c|c|c|c|c|c|c|c|c|c|c|c|c|c|c|}
\hline WELL & PROG & PROJ & 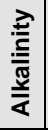 & $\frac{\frac{\pi}{0}}{\frac{0}{\alpha}}$ & 号 & 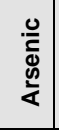 & 丞 & 屯े & 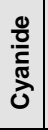 & 음 & 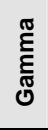 & $\begin{array}{l}0 \\
\alpha \\
\infty \\
\varnothing \\
\text { I }\end{array}$ & 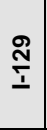 & $\underline{\underline{0}}$ & $\begin{array}{l}\frac{\infty}{0} \\
\frac{0}{d} \\
\frac{5}{0}\end{array}$ & $\begin{array}{l}\text { के } \\
\frac{1}{\omega}\end{array}$ & 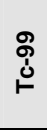 & $\stackrel{\mathscr{Q}}{\circ}$ & O & $\begin{array}{l}\underset{1}{\vdash} \\
\end{array}$ & 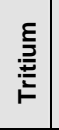 & 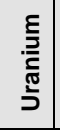 & § & Other/comments \\
\hline 199-D4-84 & CERC & ISRM & & & A & & & Qf & & Q & & & & Af & & & & & & & & A & & Q:SO4 \\
\hline 199-D4-85 & CERC & ISRM & & & A & & & Qf & & $Q$ & & & & Af & & & & & & & & A & & Q:SO4 \\
\hline 199-D4-86 & CERC & ISRM & & & A & & & Qf & & Q & & & & Af & & & & & & & & A & & Q:SO4 \\
\hline 199-D5-13 & CERC & 100HR3 & & A & A & & A & Qf & & & & & & $\mathrm{Af} / \mathrm{u}$ & & & & & & & A & & & \\
\hline 199-D5-13 & SURV & $100 \mathrm{D}$ & A & & A & & & & & & & & & Af & & & & & & & A & & & \\
\hline 199-D5-14 & CERC & 100HR3 & & A & A & & A & Qf & & & & & & Af/u & & & & & & & A & & & Former extraction well. \\
\hline 199-D5-14 & SURV & 100D & A & & A & & & & & & & & & Af & & A & & & & & & & & Former extraction well. \\
\hline 199-D5-15 & CERC & 100HR3 & & A & A & & A & Qf & & & & & & $\mathrm{Af} / \mathrm{u}$ & & & & & & & A & & & Former extraction well. \\
\hline 199-D5-15 & SURV & $100 \mathrm{D}$ & A & & A & & & & & & & & & Af & & A & & & & & A & & & Former extraction well. \\
\hline 199-D5-16 & CERC & 100HR3 & & A & A & & A & Qf & & & & & & $\mathrm{Af} / \mathrm{u}$ & & & & & & & A & & & Former extraction well. \\
\hline 199-D5-16 & SURV & $100 \mathrm{D}$ & & & & & & & & & & & & & & A & & & & & A & & & Former extraction well. \\
\hline 199-D5-17 & CERC & 100HR3 & & A & A & & A & & & & & & & $\mathrm{Af} / \mathrm{u}$ & & & & & & & A & & & \\
\hline 199-D5-17 & SURV & $100 \mathrm{D}$ & A & & A & & & & & & & & & Af & & & & & & & A & & & \\
\hline 199-D5-18 & CERC & 100HR3 & & B & B & & B & & & & & & & $\mathrm{Bf} / \mathrm{u}$ & & & & & & & B & & & FY03 \\
\hline 199-D5-19 & CERC & 100HR3 & & $\mathrm{B}$ & $\mathrm{B}$ & & B & & & & & & & $\mathrm{Bf} / \mathrm{u}$ & & & & & & & $\mathrm{B}$ & & & FY02, Former injection well. \\
\hline 199-D5-20 & CERC & 100HR3 & & A & A & & A & Qf & & & & & & $\mathrm{Af} / \mathrm{u}$ & & & & & & & A & & & \\
\hline 199-D5-20 & SURV & $100 \mathrm{D}$ & A & & A & & & & & & & & & Af & & & & & & & & & & \\
\hline 199-D5-36 & CERC & 100HR3 & & A & A & & A & Qf & & & & & & $\mathrm{Af} / \mathrm{u}$ & & & & & & & A & & & Q:SO4 \\
\hline 199-D5-36 & CERC & ISRM & & & A & & & Qf & & Q & & & & Af & & & & & & & & A & & Q:SO4 \\
\hline 199-D5-36 & SURV & $100 \mathrm{D}$ & A & & A & & & & & & & & & Af & & & & & & & & & & \\
\hline 199-D5-37 & CERC & 100HR3 & & A & A & & A & Qf & & & & & & $\mathrm{Af} / \mathrm{u}$ & & & & & & & A & & & Q:SO4 \\
\hline 199-D5-38 & CERC & 100HR3 & & A & $\mathrm{A}$ & & A & Qf & & & & & & $\mathrm{Af} / \mathrm{u}$ & & & & & & & A & & & Q:SO4 \\
\hline 199-D5-38 & CERC & ISRM & & & A & & & Qf & & Q & & & & Af & & & & & & & & A & & Q:SO4 \\
\hline 199-D5-38 & SURV & $100 \mathrm{D}$ & A & & A & & & & & & & & & Af & & & & & & & & & & \\
\hline 199-D5-39 & CERC & 100HR3 & & A & A & & A & Qf & & & & & & $\mathrm{Af} / \mathrm{u}$ & & & & & & & A & & & Q:SO4 \\
\hline 199-D5-39 & CERC & ISRM & & & A & & & Qf & & Q & & & & Af & & & & & & & & A & & Q:SO4 \\
\hline 199-D5-40 & CERC & 100HR3 & & A & A & & A & Qf & & & & & & $\mathrm{Af} / \mathrm{u}$ & & & & & & & A & & & Q:SO4 \\
\hline 199-D5-41 & CERC & 100HR3 & & A & A & & A & Qf & & & & & & $\mathrm{Af} / \mathrm{u}$ & & & & & & & $A$ & & & Q:SO4 \\
\hline 199-D5-42 & CERC & 100HR3 & & A & A & & A & Qf & & & & & & $\mathrm{Af} / \mathrm{u}$ & & & & & & & A & & & Q:SO4 \\
\hline 199-D5-42 & SURV & $100 \mathrm{D}$ & A & & A & & & & & & & & & Af & & & & & & & & & & \\
\hline 199-D5-43 & CERC & 100HR3 & & A & A & & A & Qf & & & & & & $\mathrm{Af} / \mathrm{u}$ & & & & & & & A & & & Q:SO4 \\
\hline
\end{tabular}




\begin{tabular}{|c|c|c|c|c|c|c|c|c|c|c|c|c|c|c|c|c|c|c|c|c|c|c|c|c|}
\hline WELL & PROG & PROJ & 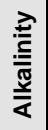 & $\frac{\frac{\pi}{2}}{\frac{2}{\alpha}}$ & $\frac{\mathscr{n}}{\frac{0}{c}}$ & 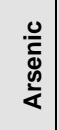 & 丞 & 屯ั & $\begin{array}{l}\frac{0}{\circ} \\
\frac{0}{\mathrm{~T}} \\
\text { Uे }\end{array}$ & ㅇ & 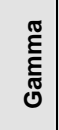 & $\begin{array}{l}\text { 웅 } \\
\infty \\
\text { 오 }\end{array}$ & $\frac{\mathbb{2}}{ \pm}$ & $\underline{0}$ & $\begin{array}{l}\frac{0}{0} \\
\frac{0}{0} \\
\frac{T}{\alpha}\end{array}$ & $\begin{array}{l}\frac{8}{0} \\
\frac{1}{5}\end{array}$ & $\begin{array}{l}\stackrel{8}{8} \\
\text { 이 }\end{array}$ & 里 & $\begin{array}{l}0 \\
\stackrel{1}{1}\end{array}$ & 음 & 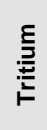 & 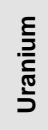 & § & Other/comments \\
\hline 199-D5-43 & CERC & ISRM & & & A & & & Qf & & Q & & & & Af & & & & & & & & A & & Q:SO4 \\
\hline 199-D5-43 & SURV & $100 \mathrm{D}$ & A & & A & & & & & & & & & Af & & & & & & & & & & \\
\hline 199-D5-44 & CERC & 100HR3 & & A & A & & A & Qf & & & & & & Af/u & & & & & & & A & & & Q:SO4 \\
\hline 199-D8-4 & CERC & 100HR3 & & A & $A$ & & A & & & & & & & $\mathrm{Af} / \mathrm{u}$ & & & & & & & A & & & \\
\hline 199-D8-4 & SURV & $100 \mathrm{D}$ & A & & $A$ & & & & & & & & & Af & & & & & & & & & & \\
\hline 199-D8-5 & CERC & 100HR3 & & A & $A$ & & A & & & & & & & $\mathrm{Af} / \mathrm{u}$ & & & & & & & A & & & \\
\hline 199-D8-53 & ERC & 100HR3 PT & & & & & & $Q$ & & & & & & & & $\mathrm{~s}$ & & & & & $\mathrm{~s}$ & & & Extraction well. \\
\hline 199-D8-54A & ERC & 100HR3 PT & & & & & & $Q$ & & & & & & & & $S$ & & & & & $\mathrm{~s}$ & & & Extraction well. \\
\hline 199-D8-54A & SURV & 100D & & & & & & Af & & & & & & & & A & & & & & & & & Extraction well. \\
\hline 199-D8-54B & CERC & 100HR3 & & A & A & & A & $\mathrm{Sf}$ & & & & & & Af/u & & & & & & & A & & & Confined Ringold (b). \\
\hline 199-D8-54B & SURV & $100 \mathrm{D}$ & $\mathrm{T}$ & & $T$ & & & & & & & & & Tf & & & & & & & $T$ & & & FY02. Confined Ringold (b). \\
\hline 199-D8-55 & CERC & $100 \mathrm{HR} 3$ & & A & $A$ & & A & Qf & & & & & & $\mathrm{Af} / \mathrm{u}$ & & & & & & & $A$ & & & \\
\hline 199-D8-55 & SURV & $100 \mathrm{D}$ & & & & & & & & & & & & & & A & & & & & & & & \\
\hline 199-D8-68 & CERC & 100HR3 & & & & & & Mf & & & & & & & & $A$ & & & & & A & & & \\
\hline 199-D8-68 & SURV & 100D & A & & A & & & & & & & & & Af & & A & & & & & & & & \\
\hline \begin{tabular}{|l|}
$199-D 8-69$ \\
\end{tabular} & CERC & 100HR3 & & & & & & Mf & & & & & & & & A & & & & & A & & & \\
\hline 199-D8-70 & CERC & 100HR3 & & & & & & M3f & & & & & & & & A & & & & & A & & & Sample 3 depth intervals for $\mathrm{Cr}$. \\
\hline 199-D8-71 & CERC & $100 \mathrm{HR} 3$ & & & & & & $\mathrm{Sf}$ & & & & & & & & & & & & & & & & \\
\hline $199-\mathrm{F} 1-2$ & LTMC & 100FR3 & & A & A & & A & & & & & & & Af & & A & & & & & A & & A & \\
\hline 199-F5-1 & $\mathrm{DOH}$ & 100F DOH & & A & $A$ & & A & & & & A & & A & & & $A$ & A & & & & A & A & & \\
\hline 199-F5-1 & LTMC & 100FR3 & A & A & $A$ & & A & & & & & & & Af & & A & & & & & A & & $A$ & \\
\hline \begin{tabular}{|l|}
$199-F 5-2$ \\
\end{tabular} & SURV & $100 \mathrm{~F}$ & A & & $A$ & & & & & A & & & & Af & & $A$ & & & & & A & & $A$ & \\
\hline 199-F5-42 & LTMC & 100FR3 & & A & A & & $A$ & & & & & & & Af & & A & & & & & A & & A & \\
\hline 199-F5-43A & LTMC & 100FR3 & A & A & A & & A & & & & & & & Af & & A & & & & & A & & A & \\
\hline 199-F5-43B & LTMC & 100FR3 & A & A & $\mathrm{A}$ & & A & & & & & & & Af & & A & & & & & A & & $\mathrm{A}$ & Deep unconfined. \\
\hline 199-F5-44 & LTMC & 100FR3 & & $\mathrm{A}$ & $\mathrm{A}$ & & A & & & & & & & Af & & A & & & & & $\mathrm{A}$ & & $\mathrm{A}$ & \\
\hline 199-F5-45 & LTMC & 100FR3 & & $\mathrm{B}$ & $Q$ & & $B$ & & & & & & & $\mathrm{Bf}$ & & $B$ & & & & & $B$ & & $\mathrm{~B}$ & FY03 \\
\hline 199-F5-46 & LTMC & 100FR3 & & A & $\mathrm{A}$ & & $\mathrm{A}$ & Qf & & & & & & Af & & A & & & & & $A$ & & $\mathrm{~A}$ & \\
\hline 199-F5-47 & LTMC & 100FR3 & & $B$ & $\mathrm{~B}$ & & $B$ & & & & & & & $\mathrm{Bf} / \mathrm{u}$ & & $B$ & & & & & $B$ & & $\mathrm{~B}$ & FY02 \\
\hline 199-F5-48 & LTMC & 100FR3 & & $\mathrm{B}$ & $B$ & & $\mathrm{~B}$ & & & & & & & $\mathrm{Bf} / \mathrm{u}$ & & $B$ & & & & & $B$ & & $\mathrm{~B}$ & FY02 \\
\hline 199-F5-6 & LTMC & 100FR3 & & A & A & & A & & & & & & & Af & & A & & & & & A & & A & \\
\hline
\end{tabular}




\begin{tabular}{|c|c|c|c|c|c|c|c|c|c|c|c|c|c|c|c|c|c|c|c|c|c|c|c|c|}
\hline WELL & PROG & PROJ & 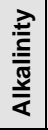 & $\frac{\frac{\pi}{2}}{\frac{0}{2}}$ & $\frac{n}{0}$ & 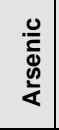 & 丞 & 屯े & 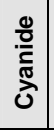 & ○ & 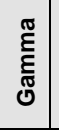 & 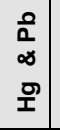 & 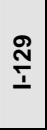 & $\underline{\underline{0}}$ & 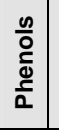 & $\begin{array}{l}\frac{8}{1} \\
\frac{1}{\omega}\end{array}$ & $\begin{array}{l}\stackrel{8}{i} \\
\dot{0}\end{array}$ & $\stackrel{\mathscr{P}}{\circ}$ & O & 음 & 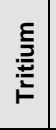 & 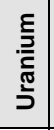 & $\stackrel{\nwarrow}{\supset}$ & Other/comments \\
\hline 199-F6-1 & LTMC & 100FR3 & & A & A & & A & & & & & & & Af & & A & & & & & A & & A & \\
\hline 199-F7-1 & LTMC & 100FR3 & & B & B & & B & & & & & & & $\mathrm{Bf} / \mathrm{u}$ & & B & & & & & B & & B & FY02 \\
\hline 199-F7-2 & LTMC & 100FR3 & & B & B & & B & & & & & & & $\mathrm{Bf} / \mathrm{u}$ & & B & & & & & B & & B & FY02 \\
\hline 199-F7-3 & LTMC & 100FR3 & & B & B & & B & & & & & & & $\mathrm{Bf} / \mathrm{u}$ & & B & & & & & B & & B & FY03 \\
\hline 199-F8-1 & SURV & $100 \mathrm{~F}$ & A & & A & & & & & A & & & & Af & & A & & & & & A & & A & \\
\hline 199-F8-2 & LTMC & 100FR3 & & B & B & & B & & & & & & & $\mathrm{Bf} / \mathrm{u}$ & & B & & & & & B & & B & FY02 \\
\hline 199-F8-3 & LTMC & 100FR3 & & B & B & & B & & & & & & & $\mathrm{Bf} / \mathrm{u}$ & & B & & & & & B & & $B$ & FY03 \\
\hline 199-F8-4 & LTMC & 100FR3 & & A & A & & A & & & & & & & Af & & A & & & & & A & & A & A:C14 \\
\hline 199-H3-2A & CERC & 100HR3 & & A & A & & A & & & & & & & $\mathrm{Af} / \mathrm{u}$ & & & & & & & A & & & Extraction well. \\
\hline 199-H3-2A & ERC & 100HR3 PT & & & & & & Q & & & & & & & & $\mathrm{s}$ & $\mathrm{s}$ & & & & $\mathrm{s}$ & $\mathrm{s}$ & & S: NO3. Extraction well. \\
\hline 199-H3-2A & SURV & $100 \mathrm{H}$ & A & & A & & & & & & & & & Af & & & & & & & A & & & Extraction well. \\
\hline 199-H3-2C & CERC & 100HR3 & & B & B & & B & & & & & & & $\mathrm{Bf} / \mathrm{u}$ & & & & & & & B & & & FY02. Deep unconfined. \\
\hline 199-H3-2C & SURV & $100 \mathrm{H}$ & A & & A & & & & & & & & & Af & & & & & & & A & & & Deep unconfined. \\
\hline $199-\mathrm{H} 4-10$ & CERC & 100HR3 & & A & A & & A & Sf & & & & & & $\mathrm{Af} / \mathrm{u}$ & & & & & & & A & & & \\
\hline 199-H4-10 & SURV & $100 \mathrm{H}$ & A & & A & & & & & & & & & Af & & & & & & & & & & \\
\hline $199-\mathrm{H} 4-11$ & ERC & 100HR3 PT & & & & & & Q & & & & & & & & $\mathrm{s}$ & $S$ & & & & $\mathrm{~S}$ & $\mathrm{~s}$ & & S: NO3. Extraction well. \\
\hline 199-H4-12A & ERC & 100HR3 PT & & & & & & Q & & & & & & & & s & S & & & & $\mathrm{S}$ & S & & S: NO3. Extraction well. \\
\hline 199-H4-12A & RCRA & $183 \mathrm{H}$ & A & & A & & & & & & & & & Af & & & A & & & & & A & & Extraction well. \\
\hline $199-\mathrm{H} 4-12 \mathrm{~A}$ & SURV & $100 \mathrm{H}$ & A & & A & & & & & & & & & Af & & A & A & & & & & A & & Extraction well. \\
\hline 199-H4-12B & CERC & 100HR3 & & & & & & Sf & & & & & & & & & & & & & & & & Mid-depth of cluster. \\
\hline $199-\mathrm{H} 4-12 \mathrm{C}$ & CERC & 100HR3 & & A & A & & A & Sf & & & & & & $\mathrm{Af} / \mathrm{u}$ & & & & & & & A & & & Deep unconfined (b). \\
\hline $199-\mathrm{H} 4-12 \mathrm{C}$ & RCRA & $183 \mathrm{H}$ & A & & A & & & & & & & & & Af & & & A & & & & & A & & Deep unconfined (b). \\
\hline $199-\mathrm{H} 4-13$ & CERC & 100HR3 & & A & A & & A & Sf & & & & & & Af/u & & & & & & & A & & & \\
\hline 199-H4-14 & CERC & 100HR3 & & $\mathrm{B}$ & B & & B & Sf & & & & & & $\mathrm{Bf} / \mathrm{u}$ & & & & & & & B & & & FY03 \\
\hline $199-\mathrm{H} 4-14$ & SURV & $100 \mathrm{H}$ & A & & A & & & & & & & & & Af & & & & & & & & & & \\
\hline 199-H4-15A & ERC & 100HR3 PT & & & & & & Q & & & & & & & & $S$ & $S$ & & & & S & $\mathrm{s}$ & & S: NO3. Extraction well. \\
\hline $199-\mathrm{H} 4-15 \mathrm{~A}$ & SURV & $100 \mathrm{H}$ & A & & A & & & & & & & & & Af & & & $\mathrm{A}$ & & & & & A & & Extraction well. \\
\hline 199-H4-15B & CERC & 100HR3 & & & & & & Sf & & & & & & & & & & & & & & & & \\
\hline 199-H4-15CP & SURV & $100 \mathrm{H}$ & $\mathrm{T}$ & & $\mathrm{T}$ & & & & & & & & & Tf & & & $\mathrm{T}$ & & & & $\mathrm{T}$ & $\mathrm{T}$ & & FY02. Top of basalt aquifer (b). \\
\hline 199-H4-15CQ & SURV & $100 \mathrm{H}$ & $T$ & & $\mathrm{~T}$ & & & & & & & & & Tf & & & & & & & & & & FY02. Confined Ringold (b). \\
\hline 199-H4-15CR & SURV & $100 \mathrm{H}$ & $\mathrm{T}$ & & $\mathrm{T}$ & & & & & & & & & Tf & & & & & & & & & & FY02. Deep unconfined (b). \\
\hline
\end{tabular}




\begin{tabular}{|c|c|c|c|c|c|c|c|c|c|c|c|c|c|c|c|c|c|c|c|c|c|c|c|c|}
\hline WELL & PROG & PROJ & 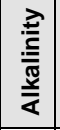 & $\frac{\frac{\pi}{2}}{\frac{0}{4}}$ & $\frac{n}{2}$ & 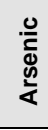 & 茕 & 屯ัँ & $\begin{array}{l}\frac{0}{0} \\
\frac{\pi}{\pi} \\
\text { ปे }\end{array}$ & 음 & 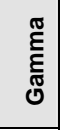 & $\begin{array}{l}\text { व̊ } \\
\infty \\
\text { o } \\
\text { I }\end{array}$ & $\frac{2}{ \pm}$ & $\underline{0}$ & $\begin{array}{l}\frac{0}{0} \\
\frac{0}{0} \\
\frac{1}{0}\end{array}$ & 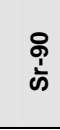 & $\begin{array}{c}\text { o } \\
\dot{\jmath} \\
\dot{1}\end{array}$ & $\stackrel{\mathscr{C}}{\circ}$ & 옹 & ํㅗㅁ & 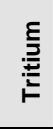 & 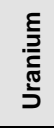 & ঠ̊ & Other/comments \\
\hline $199-\mathrm{H} 4-15 \mathrm{CS}$ & CERC & $100 \mathrm{HR} 3$ & & & & & & $\mathrm{Sf}$ & & & & & & & & & & & & & & & & Deep unconfined (b). \\
\hline 199-H4-15CS & SURV & $100 \mathrm{H}$ & $\mathrm{T}$ & & $\mathrm{T}$ & & & & & & & & & Tf & & & $\mathrm{T}$ & & & & $\mathrm{T}$ & $\mathrm{T}$ & & FY02. Deep unconfined (b). \\
\hline $199-\mathrm{H} 4-16$ & CERC & 100HR3 & & B & B & & B & $\mathrm{Sf}$ & & & & & & Bf/u & & & & & & & B & & & FY03 \\
\hline $199-\mathrm{H} 4-16$ & SURV & $100 \mathrm{H}$ & A & & A & & & & & & & & & Af & & A & & & & & & & & \\
\hline 199-H4-17 & CERC & 100HR3 & & B & B & & B & $\mathrm{Sf}$ & & & & & & $\mathrm{Bf} / \mathrm{u}$ & & & & & & & $\mathrm{B}$ & & & FY03 \\
\hline 199-H4-18 & CERC & 100HR3 & & A & A & & $\mathrm{A}$ & $\mathrm{Sf}$ & & & & & & Af/u & & & & & & & A & & & \\
\hline $199-\mathrm{H} 4-18$ & SURV & $100 \mathrm{H}$ & A & & A & & & & & & & & & Af & & A & A & & & & A & A & & \\
\hline $199-\mathrm{H} 4-2$ & SURV & Basalt & $\mathrm{T}$ & $\mathrm{T}$ & $\mathrm{T}$ & & & & & $\mathrm{T}$ & & & & $\mathrm{Tf}$ & & $\mathrm{T}$ & & & & & $\mathrm{T}$ & & & $\begin{array}{l}\text { FY03. Rattlesnake Ridge } \\
\text { Interbed (b). }\end{array}$ \\
\hline 199-H4-3 & CERC & 100HR3 & & A & A & & A & $\mathrm{Sf}$ & & & & & & Af/u & & & & & & & A & & & \\
\hline 199-H4-3 & RCRA & $183 \mathrm{H}$ & A & & A & & & & & & & & & Af & & & A & & & & & A & & \\
\hline 199-H4-3 & SURV & $100 \mathrm{H}$ & A & . & A & & & & & & & & & Af & & & A & & & & & A & & \\
\hline 199-H4-4 & CERC & 100HR3 & & A & A & & $\mathrm{A}$ & $\mathrm{Mf}$ & & & & & & Af/u & & $\mathrm{A}$ & $\mathrm{A}$ & & & & A & A & & \\
\hline $199-\mathrm{H} 4-4$ & $\mathrm{DOH}$ & $100 \mathrm{H} \mathrm{DOH}$ & & A & A & & $\mathrm{A}$ & & & & A & & A & & & & A & & & & A & A & & A:U-iso \\
\hline 199-H4-4 & SURV & $100 \mathrm{H}$ & A & $\mathrm{A}$ & $\mathrm{s}$ & & $\mathrm{A}$ & & & & A & & $\mathrm{A}$ & Af & & A & $\mathrm{s}$ & & & & & $\mathrm{s}$ & & \\
\hline 199-H4-45 & CERC & 100HR3 & & A & A & & A & $\mathrm{Sf}$ & & & & & & Af/u & & & & & & & A & & & \\
\hline 199-H4-45 & SURV & $100 \mathrm{H}$ & A & & A & & & & & & & & & Af & & A & & & & & & & & \\
\hline $199-\mathrm{H} 4-46$ & CERC & 100HR3 & & $\mathrm{B}$ & B & & $\mathrm{B}$ & $\mathrm{Sf}$ & & & & & & $\mathrm{Bf} / \mathrm{u}$ & & & & & & & $\mathrm{B}$ & & & FY03 \\
\hline 199-H4-46 & SURV & $100 \mathrm{H}$ & A & & A & & & & & & & & & Af & & A & & & & & & & & \\
\hline $199-\mathrm{H} 4-47$ & CERC & 100HR3 & & B & $B$ & & B & & & & & & & Bf/u & & & & & & & B & & & FY02 \\
\hline $199-\mathrm{H} 4-47$ & SURV & $100 \mathrm{H}$ & A & & A & & & & & & & & & $\mathrm{Af}$ & & A & & & & & & & & \\
\hline 199-H4-48 & CERC & 100HR3 & & B & $B$ & & B & $\mathrm{Sf}$ & & & & & & $\mathrm{Bf} / \mathrm{u}$ & & & & & & & B & & & FY02 \\
\hline 199-H4-48 & SURV & $100 \mathrm{H}$ & A & & A & & & & & & & & & Af & & & & & & & & & & \\
\hline 199-H4-49 & CERC & 100HR3 & & B & $B$ & & $\mathrm{~B}$ & $\mathrm{Sf}$ & & & & & & $\mathrm{Bf} / \mathrm{u}$ & & & & & & & B & & & FY02 \\
\hline 199-H4-49 & SURV & $100 \mathrm{H}$ & A & & A & & & & & & & & & Af & & & & & & & & & & \\
\hline 199-H4-5 & CERC & 100HR3 & & A & A & & A & Mf & & & & & & Af/u & & A & A & & & & A & A & & \\
\hline 199-H4-5 & SURV & $100 \mathrm{H}$ & A & & A & & & & & & & & & Af & & & A & & & & & A & & \\
\hline 199-H4-6 & CERC & 100HR3 & & B & $B$ & & B & $\mathrm{Sf}$ & & & & & & $\mathrm{Bf} / \mathrm{u}$ & & & & & & & B & & & FY03 \\
\hline 199-H4-63 & CERC & 100HR3 & & $\mathrm{A}$ & $\mathrm{A}$ & & $\mathrm{A}$ & $\mathrm{Mf}$ & & & & & & $\mathrm{Af} / \mathrm{u}$ & & A & A & & & & $\mathrm{A}$ & A & & \\
\hline 199-H4-63 & SURV & $100 \mathrm{H}$ & A & & A & & & & & & & & & Af & & A & & & & & & & & \\
\hline 199-H4-64 & CERC & 100HR3 & & A & A & & A & Mf & & & & & & $\mathrm{Af} / \mathrm{u}$ & & A & A & & & & A & A & & \\
\hline
\end{tabular}




\begin{tabular}{|c|c|c|c|c|c|c|c|c|c|c|c|c|c|c|c|c|c|c|c|c|c|c|c|c|}
\hline WELL & PROG & PROJ & 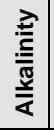 & $\frac{\frac{\pi}{2}}{\frac{0}{\alpha}}$ & $\begin{array}{l}0 \\
\vdots \\
\frac{0}{E} \\
\frac{2}{<}\end{array}$ & $\begin{array}{l}0 \\
\stackrel{0}{\bar{J}} \\
\frac{\omega}{\alpha}\end{array}$ & Фٓ & 屯े & 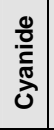 & 음 & 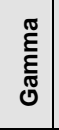 & 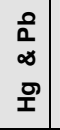 & 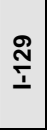 & $\underline{\underline{0}}$ & $\begin{array}{c}\frac{\infty}{0} \\
\frac{\bar{\omega}}{\alpha} \\
\frac{\bar{L}}{2}\end{array}$ & $\begin{array}{l}\frac{8}{1} \\
\frac{1}{\omega}\end{array}$ & $\begin{array}{l}\stackrel{8}{i} \\
\dot{0} \\
-\end{array}$ & $\stackrel{\mathscr{P}}{\circ}$ & O & ํㅏㅁ & 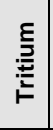 & 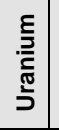 & § & Other/comments \\
\hline $199-\mathrm{H} 4-65$ & ERC & 100HR3 PT & & & & & & $Q$ & & & & & & & & $\mathrm{~s}$ & $\mathrm{~s}$ & & & & $\mathrm{~S}$ & $\mathrm{~s}$ & & S: NO3. Extraction well. \\
\hline 199-H4-7 & ERC & 100HR3 PT & & & & & & Q & & & & & & & & $\mathrm{s}$ & $\mathrm{s}$ & & & & $\mathrm{s}$ & $\mathrm{s}$ & & S: NO3. Extraction well. \\
\hline 199-H4-7 & RCRA & $183 \mathrm{H}$ & A & & A & & & & & & & & & Af & & & A & & & & & A & & Extraction well. \\
\hline 199-H4-7 & SURV & $100 \mathrm{H}$ & A & & A & & & & & & & & & Af & & & A & & & & & A & & Extraction well. \\
\hline $199-\mathrm{H} 4-8$ & CERC & 100HR3 & & $\mathrm{B}$ & B & & B & Sf & & & & & & $\mathrm{Bf} / \mathrm{u}$ & & & & & & & B & & & FY03 \\
\hline $199-\mathrm{H} 4-9$ & CERC & $100 \mathrm{HR} 3$ & & B & B & & B & & & & & & & $\mathrm{Bf} / \mathrm{u}$ & & & & & & & $B$ & & & FY02 \\
\hline $199-\mathrm{H} 4-9$ & SURV & $100 \mathrm{H}$ & A & & A & & & & & & & & & Af & & & A & & & & & A & & \\
\hline 199-H5-1A & CERC & 100HR3 & & B & B & & B & Sf & & & & & & $\mathrm{Bf} / \mathrm{u}$ & & & & & & & B & & & FY03 \\
\hline 199-H5-1A & SURV & $100 \mathrm{H}$ & A & & A & & & & & & & & & Af & & & & & & & & & & \\
\hline 199-H6-1 & CERC & 100HR3 & & A & A & & A & & & & & & & $\mathrm{Af} / \mathrm{u}$ & & & & & & & A & & & \\
\hline 199-H6-1 & SURV & $100 \mathrm{H}$ & A & & A & & & & & & & & & Af & & A & & & & & & & & \\
\hline $199-K-106 A$ & CERC & 100KR4 & & B & B & & B & & & & B & & & $\mathrm{Bf} / \mathrm{u}$ & & & & & & & B & & & FY02. B:C14 \\
\hline $199-K-106 A$ & SURV & $100 \mathrm{~K}$ & A & & & & & & & & & & & Af & & & & & & & & & A & A:C14 \\
\hline 199-K-106A & SURV & 100K BASIN & & $\mathrm{Q}$ & $\mathrm{Q}$ & & $\mathrm{Q}$ & & & $\mathrm{Q}$ & & & & & & & & & & & $\mathrm{Q}$ & & & \\
\hline 199-K-107A & CERC & 100KR4 & & A & A & & A & Qf & & & A & & & Af/u & & & & & & & A & & & \\
\hline 199-K-107A & SURV & $100 \mathrm{~K}$ & & & & & & & & & & & & Af & & & & & & & & & & A:C14 \\
\hline 199-K-107A & SURV & 100K BASIN & & $Q$ & $\mathrm{Q}$ & & Q & & & Q & & & & & & & & & & & Q & & & \\
\hline 199-K-108A & CERC & 100KR4 & & $\mathrm{A}$ & $\mathrm{A}$ & & A & Qf & & & A & & & $\mathrm{Af} / \mathrm{u}$ & & & & & & & A & & & A:C14 \\
\hline 199-K-108A & SURV & $100 \mathrm{~K}$ & & & & & & & & & & & & Af & & & & & & & & & & A:C14 \\
\hline 199-K-108A & SURV & 100K BASIN & & $\mathrm{Q}$ & Q & & $\mathrm{Q}$ & & & Q & & & & & & & & & & & $\mathrm{Q}$ & & & \\
\hline 199-K-109A & CERC & 100KR4 & & A & A & & A & & & & A & & & $\mathrm{Af} / \mathrm{u}$ & & $\mathrm{Q}$ & & & & & A & & & \\
\hline 199-K-109A & $\mathrm{DOH}$ & $100 \mathrm{~K} \mathrm{DOH}$ & & $\mathrm{s}$ & $\mathrm{s}$ & & $\mathrm{s}$ & & & & $\mathrm{s}$ & & & & & $\mathrm{s}$ & & & & & $S$ & & & S:C14, Pu-iso \\
\hline 199-K-109A & SURV & $100 \mathrm{~K}$ & & & & & & & & & & & & Af & & & & & & & & & & A:C14 \\
\hline 199-K-109A & SURV & 100K BASIN & & $\mathrm{Q}$ & Q & & $\mathrm{M}$ & & & $\mathrm{M}$ & & & & & & Q & Q & & & & M & & & \\
\hline $199-K-11$ & CERC & 100KR4 & & B & B & & $\mathrm{B}$ & & & & B & & & $\mathrm{Bf} / \mathrm{u}$ & & & & & & & B & & & FY03 \\
\hline $199-K-11$ & SURV & $100 \mathrm{~K}$ & & & A & & A & & & A & & & & Af & & & & & & & A & & & A:C14 \\
\hline $199-\mathrm{K}-110 \mathrm{~A}$ & CERC & 100KR4 & & B & B & & $\mathrm{B}$ & & & & B & & & $\mathrm{Bf} / \mathrm{u}$ & & & & & & & $B$ & & & FY02 \\
\hline 199-K-110A & SURV & $100 \mathrm{~K}$ & & & & & & & & & & & & Af & & & & & & & & & & $A: C 14$ \\
\hline 199-K-110A & SURV & 100K BASIN & & $\mathrm{Q}$ & $\mathrm{Q}$ & & Q & & & Q & & & & & & & & & & & $\mathrm{Q}$ & & & \\
\hline $199-K-111 \mathrm{~A}$ & CERC & 100KR4 & & A & A & & A & & & & A & & & Af/u & & & & & & & A & & & $A: C 14$ \\
\hline 199-K-111A & SURV & $100 \mathrm{~K}$ & & Q & A & & Q & & & Q & & & & Af & & & A & & & & Q & & & A:C14 \\
\hline
\end{tabular}




\begin{tabular}{|c|c|c|c|c|c|c|c|c|c|c|c|c|c|c|c|c|c|c|c|c|c|c|c|c|}
\hline WELL & PROG & PROJ & 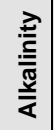 & $\frac{\frac{\pi}{0}}{\frac{0}{\alpha}}$ & $\frac{\mathscr{0}}{\frac{0}{c}}$ & 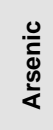 & 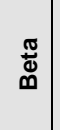 & ثั้ & $\begin{array}{l}\frac{0}{0} \\
\frac{0}{\mathrm{~T}} \\
\text { ปे }\end{array}$ & 웅 & 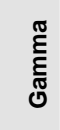 & $\begin{array}{l}0 \\
0 \\
\infty \\
ㅁ \\
\text { I }\end{array}$ & $\frac{\text { N }}{I}$ & $\stackrel{0}{0}$ & $\begin{array}{l}\frac{0}{0} \\
\frac{0}{\Phi} \\
\frac{5}{\alpha}\end{array}$ & $\begin{array}{l}\text { के } \\
\frac{1}{\omega}\end{array}$ & $\begin{array}{l}\stackrel{8}{\grave{d}} \\
\stackrel{\circ}{\circ}\end{array}$ & $\stackrel{\text { D }}{\mathfrak{R}}$ & $\underset{\wp}{0}$ & 음 & 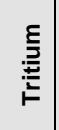 & 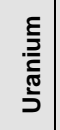 & ঠ̊ & Other/comments \\
\hline $199-K-112 A$ & ERC & 100KR4 PT & & & & & & Q & & & & & & & & $\mathrm{s}$ & & & & & $\mathrm{s}$ & & & Extraction well. \\
\hline 199-K-113A & ERC & 100KR4 PT & & & & & & $Q$ & & & & & & & & $\mathrm{~s}$ & & & & & $\mathrm{~s}$ & & & Extraction well. \\
\hline 199-K-114A & CERC & 100KR4 & & & & & & Mf & & & & & & & & A & & & & & A & & & \\
\hline 199-K-114A & SURV & $100 \mathrm{~K}$ & & & & & & & & A & & & & & & A & & & & & & & & \\
\hline 199-K-115A & ERC & 100KR4 PT & & & & & & Q & & & & & & & & $S$ & & & & & $\mathrm{~s}$ & & & Extraction well. \\
\hline $199-K-116 \mathrm{~A}$ & ERC & 100KR4 PT & & & & & & $Q$ & & & & & & & & $\mathrm{~S}$ & & & & & $S$ & & & Extraction well. \\
\hline 199-K-117A & CERC & 100KR4 & & & & & & M4f & & & & & & & & A & & & & & A & & & 4 depth intervals for $\mathrm{Cr}$. \\
\hline 199-K-117A & SURV & $100 \mathrm{~K}$ & & & A & & & & & A & & & & Af & & A & & & & & & & & \\
\hline 199-K-119A & ERC & 100KR4 PT & & & & & & $Q$ & & & & & & & & $S$ & & & & & $S$ & & & Extraction well. \\
\hline 199-K-120A & ERC & 100KR4 PT & & & & & & $Q$ & & & & & & & & $\mathrm{~s}$ & & & & & $S$ & & & Extraction well. \\
\hline 199-K-125A & ERC & 100KR4 PT & & & & & & $Q$ & & & & & & & & $\mathrm{~s}$ & & & & & $\mathrm{~s}$ & & & Extraction well. \\
\hline 199-K-126A & CERC & 100KR4 & & & & & & Mf & & & & & & & & A & & & & & A & & & \\
\hline 199-K-18 & CERC & 100KR4 & & A & A & & A & Mf & & & A & & & Af $/ \mathrm{u}$ & & $A$ & & & & & A & & & \\
\hline 199-K-18 & SURV & $100 \mathrm{~K}$ & & & A & & & & & A & & & & Af & & & & & & & A & & & \\
\hline 199-K-19 & CERC & 100KR4 & & $\mathrm{A}$ & A & & $\mathrm{A}$ & $\mathrm{Sf}$ & & & $A$ & & & Af/u & & & & & & & A & & & \\
\hline 199-K-19 & SURV & $100 \mathrm{~K}$ & & & A & & $\mathrm{A}$ & & & A & & & & Af & & & & & & & A & & & \\
\hline $199-K-20$ & CERC & 100KR4 & & $A$ & A & & A & Mf & & & A & & & $\mathrm{Af} / \mathrm{u}$ & & A & & & & & A & & & \\
\hline \begin{tabular}{|l|}
$199-K-21$ \\
\end{tabular} & CERC & 100KR4 & & $A$ & A & & $A$ & $\mathrm{Sf}$ & & & $A$ & & & $\mathrm{Af} / \mathrm{u}$ & & & & & & & A & & & \\
\hline \begin{tabular}{|l|}
$199-K-21$ \\
\end{tabular} & SURV & $100 \mathrm{~K}$ & & & & & & & & A & & & & & & A & & & & & & & & \\
\hline 199-K-22 & CERC & 100KR4 & & $A$ & A & & A & $\mathrm{Sf}$ & & & A & & & Af/u & & & & & & & A & & & \\
\hline 199-K-22 & SURV & $100 \mathrm{~K}$ & & & $\mathrm{~A}$ & & & & & A & & & & Af & & $A$ & & & & & A & & & \\
\hline 199-K-23 & CERC & 100KR4 & & B & $B$ & & $B$ & & & & $B$ & & & $\mathrm{Bf} / \mathrm{u}$ & & & & & & & B & & & FY03 \\
\hline 199-K-23 & SURV & $100 \mathrm{~K}$ & & & A & & A & & & $A$ & & & & Af & & & & & & & & & & \\
\hline 199-K-27 & CERC & 100KR4 & & $B$ & $\mathrm{~B}$ & & $B$ & & & & $B$ & & & $\mathrm{Bf} / \mathrm{u}$ & & $Q$ & & & & & $B$ & & & \\
\hline 199-K-27 & $\mathrm{DOH}$ & $100 \mathrm{~K} \mathrm{DOH}$ & & $\mathrm{s}$ & $S$ & & $\mathrm{~s}$ & & & & $S$ & & & & & & & & & & $S$ & & & \\
\hline \begin{tabular}{|l|}
$199-K-27$ \\
\end{tabular} & SURV & 100K BASIN & & $Q$ & $Q$ & & $Q$ & & & $Q$ & & & & & & $Q$ & $Q$ & & & & $Q$ & & & \\
\hline \begin{tabular}{|l|}
$199-K-28$ \\
\end{tabular} & SURV & $100 \mathrm{~K}$ & & & & & & & & & & & & Af & & & & & & & & & & A:C14 \\
\hline \begin{tabular}{|l|}
$199-K-28$ \\
\end{tabular} & SURV & 100K BASIN & & $Q$ & $Q$ & & $Q$ & & & $Q$ & & & & & & & & & & & $Q$ & & & \\
\hline \begin{tabular}{|l|}
$199-K-29$ \\
\end{tabular} & SURV & $100 \mathrm{~K}$ & & & & & & & & & & & & Af & & & & & & & & & & A:C14 \\
\hline 199-K-29 & SURV & 100K BASIN & & $Q$ & $Q$ & & $Q$ & & & $Q$ & & & & & & & & & & & $Q$ & & & \\
\hline 199-K-30 & CERC & 100KR4 & & B & B & & $B$ & & & & B & & & $\mathrm{Bf} / \mathrm{u}$ & & $Q$ & & & & & $B$ & & & FY03. B:C14 \\
\hline
\end{tabular}




\begin{tabular}{|c|c|c|c|c|c|c|c|c|c|c|c|c|c|c|c|c|c|c|c|c|c|c|c|c|}
\hline WELL & PROG & PROJ & 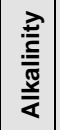 & $\frac{\frac{\pi}{0}}{\frac{0}{\alpha}}$ & $\begin{array}{l}\frac{n}{2} \\
\frac{0}{\frac{L}{L}}\end{array}$ & 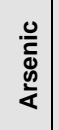 & 丞 & ثั้ & $\begin{array}{l}\frac{0}{0} \\
\frac{0}{\mathrm{~T}} \\
\text { ปे }\end{array}$ & ○ & 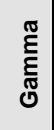 & $\begin{array}{l}0 \\
0 \\
\infty \\
\text { 오 }\end{array}$ & $\stackrel{\text { ని }}{1}$ & $\stackrel{0}{0}$ & $\begin{array}{l}\frac{0}{0} \\
\frac{0}{0} \\
\frac{5}{\alpha}\end{array}$ & 各 & $\begin{array}{l}\stackrel{8}{8} \\
\dot{0}\end{array}$ & $\stackrel{\text { 足 }}{口}$ & $\begin{array}{l}0 \\
\stackrel{\circ}{\prime}\end{array}$ & 임 & 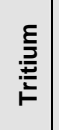 & 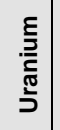 & ঠ & Other/comments \\
\hline 199-K-30 & SURV & $100 \mathrm{~K}$ & A & & & & & & & & & & & Af & & & & & & & & & & A:C14 \\
\hline 199-K-30 & SURV & 100K BASIN & & $Q$ & $Q$ & & $Q$ & & & $Q$ & & & & & & & & & & & $Q$ & & & \\
\hline |199-K-31 & CERC & 100KR4 & & A & A & & A & & & & A & & & Af $/ u$ & & & & & & & A & & & \\
\hline $199-K-31$ & SURV & $100 \mathrm{~K}$ & & & A & & $A$ & & & A & & & & Af & & & A & & & & A & & & \\
\hline 199-K-32A & CERC & 100KR4 & & A & A & & $\mathrm{A}$ & & & & A & & & $\mathrm{Af} / \mathrm{u}$ & & & & & & & A & & & A:C14 \\
\hline 199-K-32A & SURV & $100 \mathrm{~K}$ & & $Q$ & $Q$ & & $Q$ & & & $Q$ & & & & Af & & & A & & & & $Q$ & & & $A: C 14$ \\
\hline 199-K-32B & CERC & 100KR4 & & A & A & & $A$ & & & & A & & & Af/u & & & & & & & A & & & Deep unconfined. \\
\hline 199-K-32B & SURV & $100 \mathrm{~K}$ & $\mathrm{~T}$ & & $\mathrm{~T}$ & & & & & $\mathrm{~T}$ & & & & $\mathrm{Tf}$ & & & & & & & $\mathrm{T}$ & & & FY02. Deep unconfined. \\
\hline 199-K-33 & CERC & 100KR4 & & A & A & & A & & & & A & & & Af/u & & & & & & & A & & & A:C14 \\
\hline 199-K-33 & SURV & $100 \mathrm{~K}$ & & & A & & $\mathrm{A}$ & & & A & & & & $\mathrm{Af}$ & & & & & & & A & & A & A:C14 \\
\hline 199-K-34 & CERC & 100KR4 & & $B$ & $B$ & & B & & & & B & & & $\mathrm{Bf} / \mathrm{u}$ & & & & & & & B & & & FY03. B:C14 \\
\hline $199-K-34$ & SURV & $100 \mathrm{~K}$ & & & & & & & & & & & & Af & & & & & & & & & & A:C14 \\
\hline 199-K-34 & SURV & 100K BASIN & & $Q$ & $Q$ & & $Q$ & & & Q & & & & & & & & & & & $Q$ & & & \\
\hline 199-K-35 & CERC & 100KR4 & & $\mathrm{B}$ & $\mathrm{B}$ & & $\mathrm{B}$ & & & & $\mathrm{B}$ & & & $\mathrm{Bf} / \mathrm{u}$ & & & & & & & $\mathrm{B}$ & & & FY03. \\
\hline 199-K-36 & CERC & 100KR4 & & A & A & & A & Qf & & & A & & & $\mathrm{Af} / \mathrm{u}$ & & & & & & & A & & & A: $\mathrm{Hg} \mathrm{f} / \mathrm{u}$ \\
\hline 199-K-36 & SURV & $100 \mathrm{~K}$ & & & A & & & & & A & & & & Af & & & & & & & A & & & \\
\hline 199-K-37 & CERC & 100KR4 & & A & A & & A & $\mathrm{Sf}$ & & & A & & & Af/u & & & & & & & A & & & \\
\hline 199-N-103A & SURV & $100 \mathrm{~N}$ & & & & & & & & & & & & & & $Q$ & & & & & & & & Extraction well. \\
\hline $199-\mathrm{N}-105 \mathrm{~A}$ & RCRA & $1301 \mathrm{~N}$ & A & & A & & & & & & & & & Af & & & & & S4 & S4 & & & & Backup extraction well. \\
\hline 199-N-105A & SURV & $100 \mathrm{~N}$ & $A$ & & A & & & & & & & & & Af & & $S$ & & & & & & & & Backup extraction well. \\
\hline $199-\mathrm{N}-106 \mathrm{~A}$ & SURV & $100 \mathrm{~N}$ & & & & & & & & & & & & & & $Q$ & & & & & & & & Extraction well. \\
\hline $199-\mathrm{N}-14$ & CERC & 100NR2 & & & $\mathrm{s}$ & & $\mathrm{s}$ & & & & & & & $\mathrm{Sf}$ & & $\mathrm{s}$ & & & & & $\mathrm{s}$ & & & \\
\hline $199-\mathrm{N}-14$ & $\mathrm{DOH}$ & $100 \mathrm{~N} \mathrm{DOH}$ & & $S$ & $\mathrm{~s}$ & & $\mathrm{~s}$ & & & & $S$ & & & & & $S$ & & & & & $S$ & & & \\
\hline $199-\mathrm{N}-14$ & SURV & $100 \mathrm{~N}$ & $S$ & & $\mathrm{~s}$ & & & & & & & & & $\mathrm{Sf}$ & & $S$ & & & & & $S$ & & & \\
\hline $199-\mathrm{N}-16$ & CERC & 100NR2 & & & A & & $A$ & & & & & & & Af & & $\mathrm{A}$ & & & & & & & & A:O\&G, TPH \\
\hline 199-N-16 & SURV & $100 \mathrm{~N}$ & A & & A & & & & & & & & & Af & & & & & & & & & & \\
\hline $199-\mathrm{N}-18$ & CERC & 100NR2 & & & & & & & & & & & & & & & & & & & & & & A:O\&G, TPH \\
\hline $199-\mathrm{N}-18$ & SURV & $100 \mathrm{~N}$ & $A$ & & A & & & & & & & & & Af & & & & & & & & & & A:O\&G, TPH \\
\hline 199-N-19 & SURV & $100 \mathrm{~N}$ & $\mathrm{~T}$ & & $\mathrm{~T}$ & & & & & & & & & Tf & & $\mathrm{T}$ & & & & & & & & FY02 \\
\hline $199-\mathrm{N}-2$ & CERC & 100NR2 & & & A & & A & & & & & & & Af & & A & & & & & $\mathrm{A}$ & & & \\
\hline $199-\mathrm{N}-2$ & RCRA & $1301 \mathrm{~N}$ & A & & A & & & & & & & & & Af & & & & & S4 & S4 & & & & \\
\hline
\end{tabular}




\begin{tabular}{|c|c|c|c|c|c|c|c|c|c|c|c|c|c|c|c|c|c|c|c|c|c|c|c|c|}
\hline WELL & PROG & PROJ & 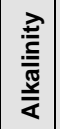 & $\frac{\frac{\pi}{2}}{\frac{0}{\alpha}}$ & $\begin{array}{l}n \\
\frac{n}{2} \\
\frac{0}{\bar{\alpha}}\end{array}$ & $\begin{array}{l}\frac{0}{\bar{T}} \\
\frac{\Phi}{\alpha} \\
\frac{\vec{\alpha}}{\alpha}\end{array}$ & Ф̊ & 屯ेँ & $\begin{array}{l}\frac{0}{0} \\
\frac{0}{\mathrm{~T}} \\
\text { Uे }\end{array}$ & 웅 & 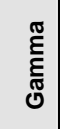 & $\begin{array}{l}\text { व̊ } \\
\infty \\
\text { o } \\
\text { I }\end{array}$ & $\underset{\text { 오 }}{1}$ & $\underline{0}$ & $\begin{array}{l}\frac{\infty}{0} \\
\frac{\sigma}{0} \\
\frac{0}{\alpha}\end{array}$ & $\begin{array}{l}\text { के } \\
\frac{1}{\omega}\end{array}$ & $\begin{array}{l}\stackrel{8}{d} \\
\text { in }\end{array}$ & $\stackrel{\text { 足 }}{\circ}$ & 온 & 옴 & 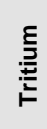 & 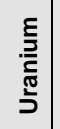 & §ీ & Other/comments \\
\hline $199-\mathrm{N}-2$ & SURV & $100 \mathrm{~N}$ & A & & A & & & & & & & & & Af & & & & & & & & & & \\
\hline $199-\mathrm{N}-21$ & CERC & 100NR2 & & & A & & & & & & & & & Af & & & & & & & & & & \\
\hline $199-\mathrm{N}-21$ & SURV & $100 \mathrm{~N}$ & A & & A & & & & & & & & & Af & & & & & & & & & & \\
\hline $199-\mathrm{N}-26$ & SURV & $100 \mathrm{~N}$ & A & & A & & & & & & & & & Af & & & & & & & & & & \\
\hline $199-\mathrm{N}-27$ & CERC & 100NR2 & & A & A & & & & & & A & & & Af & & & & & & & A & & & \\
\hline $199-\mathrm{N}-27$ & SURV & $100 \mathrm{~N}$ & & & & & & & & & & & & & & A & & & & & & & & \\
\hline $199-\mathrm{N}-28$ & RCRA & $1325 \mathrm{~N}$ & A & & A & & & & & & & & & Af & & & & & $\mathrm{s}$ & $\mathrm{s}$ & & & & \\
\hline $199-\mathrm{N}-28$ & SURV & $100 \mathrm{~N}$ & A & & A & & & & & & & & & Af & & A & & & & & A & & & \\
\hline $199-\mathrm{N}-3$ & CERC & 100NR2 & & & $\mathrm{s}$ & & $\mathrm{s}$ & & & & & & & Sf & & S & & & & & $\mathrm{s}$ & & & \\
\hline $199-\mathrm{N}-3$ & RCRA & $1301 \mathrm{~N}$ & A & & A & & & & & & & & & Af & & & & & S4 & S4 & & & & \\
\hline $199-\mathrm{N}-3$ & SURV & $100 \mathrm{~N}$ & A & & A & & & & & & & & & Af & & A & & & & & A & & & A:O\&G, TPH \\
\hline $199-\mathrm{N}-32$ & CERC & 100NR2 & & & $\mathrm{s}$ & & $\mathrm{s}$ & & & & $\mathrm{s}$ & & & $\mathrm{Sf}$ & & $\mathrm{s}$ & & & & & $\mathrm{s}$ & & & \\
\hline $199-N-32$ & RCRA & $1325 \mathrm{~N}$ & $\mathrm{~s}$ & & $\mathrm{~s}$ & & & & & & & & & $\mathrm{Sf}$ & & & & & S4 & S4 & & & & \\
\hline $199-\mathrm{N}-32$ & SURV & $100 \mathrm{~N}$ & A & & A & & & & & & & & & Af & & & & & & & A & & & \\
\hline $199-\mathrm{N}-34$ & RCRA & $1301 \mathrm{~N}$ & A & & A & & & & & & & & & Af & & & & & S4 & S4 & & & & \\
\hline $199-\mathrm{N}-34$ & SURV & $100 \mathrm{~N}$ & A & & A & & & & & & & & & Af & & A & & & & & A & & & \\
\hline $199-\mathrm{N}-41$ & RCRA & $1325 \mathrm{~N}$ & A & & A & & & & & & & & & Af & & & & & S4 & S4 & & & & \\
\hline $199-\mathrm{N}-41$ & SURV & $100 \mathrm{~N}$ & A & & A & & & & & & & & & Af & & A & & & & & A & & & \\
\hline $199-\mathrm{N}-46$ & SURV & $100 \mathrm{~N}$ & & & & & & & & & & & & & & $\mathrm{~s}$ & & & & & $\mathrm{~s}$ & & & \\
\hline $199-\mathrm{N}-47$ & SURV & $100 \mathrm{~N}$ & $\mathrm{~T}$ & & $\mathrm{~T}$ & & & & & & & & & Tf & & & & & & & & & & FY02 \\
\hline $199-\mathrm{N}-50$ & CERC & 100NR2 & & & & & A & & & & & & & & & & & & & & A & & & \\
\hline $199-N-50$ & SURV & $100 \mathrm{~N}$ & $\mathrm{~T}$ & & $\mathrm{~T}$ & & & & & & & & & Tf & & & & & & & $\mathrm{T}$ & & & FY02 \\
\hline $199-\mathrm{N}-51$ & CERC & 100NR2 & & & & & A & & & & & & & & & & & & & & A & & & \\
\hline $199-\mathrm{N}-51$ & SURV & $100 \mathrm{~N}$ & & & & & & & & & & & & & & & & & & & A & & & \\
\hline $199-\mathrm{N}-52$ & SURV & $100 \mathrm{~N}$ & $\mathrm{~T}$ & & $\mathrm{~T}$ & & & & & & & & & Tf & & & & & & & $\mathrm{T}$ & & & FY02 \\
\hline $199-\mathrm{N}-56$ & SURV & $100 \mathrm{~N}$ & A & & A & & & & & & & & & Af & & A & & & & & A & & & \\
\hline $199-\mathrm{N}-57$ & RCRA & $1301 \mathrm{~N}$ & A & & A & & & & & & & & & Af & & & & & S4 & S4 & & & & \\
\hline $199-N-57$ & SURV & $100 \mathrm{~N}$ & A & & A & & & & & & & & & Af & & A & & & & & & & & \\
\hline $199-N-59$ & RCRA & $1324 \mathrm{~N}$ & $\mathrm{~s}$ & $\mathrm{~s}$ & $\mathrm{~s}$ & & & & & & & & & $\mathrm{Sf}$ & & & & & S4 & S4 & & & & Dry when water table low. \\
\hline $199-\mathrm{N}-59$ & SURV & $100 \mathrm{~N}$ & $\mathrm{~s}$ & & $\mathrm{~s}$ & & & & & & & & & $\mathrm{Sf}$ & & & & & $\mathrm{s}$ & $\mathrm{s}$ & & & & Dry when water table low. \\
\hline $199-\mathrm{N}-64$ & CERC & 100NR2 & & & A & & A & & & & & & & Af & & A & & & & & A & & & \\
\hline
\end{tabular}




\begin{tabular}{|c|c|c|c|c|c|c|c|c|c|c|c|c|c|c|c|c|c|c|c|c|c|c|c|c|}
\hline WELL & PROG & PROJ & 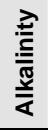 & $\frac{\frac{\pi}{0}}{\frac{0}{\alpha}}$ & $\frac{\mathscr{0}}{0}$ & 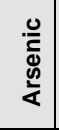 & Фّ & 屯ัँ & 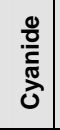 & 8 & $\begin{array}{l}\text { हू } \\
\text { हू } \\
\text { હ }\end{array}$ & $\begin{array}{l}\text { 유 } \\
\infty \\
\text { 오 }\end{array}$ & 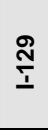 & $\stackrel{0}{0}$ & $\begin{array}{l}\frac{0}{0} \\
\frac{0}{\Phi} \\
\frac{\pi}{\alpha}\end{array}$ & $\begin{array}{l}\text { के } \\
\frac{1}{\omega}\end{array}$ & $\begin{array}{l}\stackrel{8}{\grave{d}} \\
\stackrel{0}{\circ}\end{array}$ & 里 & 옹 & 옴 & 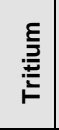 & 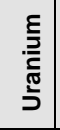 & $\stackrel{\nwarrow}{\supset}$ & Other/comments \\
\hline $199-N-64$ & SURV & $100 \mathrm{~N}$ & A & & A & & & & & & & & & Af & & A & & & & & A & & & \\
\hline $199-\mathrm{N}-67$ & CERC & 100NR2 & & $\mathrm{s}$ & $\mathrm{s}$ & & $\mathrm{s}$ & & & & Q & & & Sf & & $\mathrm{s}$ & & & & & & & & Little water remains. \\
\hline $199-\mathrm{N}-67$ & SURV & $100 \mathrm{~N}$ & A & & A & & & & & & & & & Af & & Q & & & & & A & & & Little water remains. \\
\hline $199-\mathrm{N}-69$ & SURV & $100 \mathrm{~N}$ & & & & & & & & & & & & & & $\mathrm{~T}$ & & & & & $\mathrm{~T}$ & & & FY02. Bottom upper aquifer. \\
\hline $199-\mathrm{N}-70$ & CERC & 100NR2 & & A & A & & A & & & & A & & & Af & & A & & & & & A & & & Bottom upper aquifer. \\
\hline $199-N-71$ & RCRA & $1324 \mathrm{~N}$ & A & & A & & & & & & & & & Af & & & & & S4 & S4 & & & & \\
\hline $199-\mathrm{N}-72$ & RCRA & $1324 \mathrm{~N}$ & $S$ & & $S$ & & & & & & & & & $\mathrm{Sf}$ & & & & & S4 & S4 & & & & \\
\hline $199-\mathrm{N}-73$ & RCRA & $1324 \mathrm{~N}$ & $\mathrm{~s}$ & & $S$ & & & & & & & & & $\mathrm{Sf}$ & & & & & S4 & S4 & & & & \\
\hline $199-\mathrm{N}-73$ & SURV & $100 \mathrm{~N}$ & A & & A & & & & & & & & & Af & & & & & & & & & & \\
\hline $199-\mathrm{N}-74$ & CERC & 100NR2 & & A & & & A & & & & A & & & Af & & & & & & & & & & \\
\hline $199-\mathrm{N}-74$ & RCRA & $1325 \mathrm{~N}$ & A & & A & & & & & & & & & Af & & & & & S4 & S4 & & & & \\
\hline $199-\mathrm{N}-74$ & SURV & $100 \mathrm{~N}$ & $\mathrm{~T}$ & & $\mathrm{~T}$ & & & & & & & & & Tf & & & & & & & $\mathrm{T}$ & & & FY02 \\
\hline 199-N-75 & CERC & 100NR2 & & & $\mathrm{s}$ & & $S$ & & & & & & & Sf & & $\mathrm{s}$ & & & & & $S$ & & & Extraction well. \\
\hline $199-\mathrm{N}-75$ & SURV & $100 \mathrm{~N}$ & A & & A & & & & & & & & & Af & & $\mathrm{Q}$ & & & & & & & & Extraction well. \\
\hline $199-\mathrm{N}-76$ & CERC & 100NR2 & & & $S$ & & $S$ & & & & $\mathrm{~s}$ & & & $\mathrm{Sf}$ & & S & & & & & $\mathrm{s}$ & & & \\
\hline $199-\mathrm{N}-76$ & SURV & $100 \mathrm{~N}$ & & & & & & & & & & & & & & A & & & & & & & & \\
\hline $199-\mathrm{N}-77$ & RCRA & $1324 \mathrm{~N}$ & A & A & A & & & & & & & & & Af & & & & & $\mathrm{S}$ & $S$ & & & & Bottom upper aquifer. \\
\hline $199-\mathrm{N}-80$ & CERC & 100NR2 & & $\mathrm{A}$ & A & & A & & & & A & & & Af & & A & & & & & A & & & Confined Ringold. \\
\hline $199-\mathrm{N}-80$ & SURV & $100 \mathrm{~N}$ & $\mathrm{~T}$ & & $\mathrm{~T}$ & & & & & & & & & Tf & & $\mathrm{T}$ & & & & & $\mathrm{T}$ & & & FY02. Confined Ringold. \\
\hline $199-\mathrm{N}-81$ & CERC & 100NR2 & & & A & & A & & & & & & & Af & & A & & & & & A & & & \\
\hline $199-\mathrm{N}-81$ & RCRA & $1325 \mathrm{~N}$ & A & & A & & & & & & & & & Af & & & & & S4 & S4 & & & & \\
\hline $199-\mathrm{N}-81$ & SURV & $100 \mathrm{~N}$ & & & & & & & & & Q & & & & & Q & & & & & & & & \\
\hline $199-\mathrm{N}-92 \mathrm{~A}$ & CERC & 100NR2 & & & A & & A & & & & & & & Af & & A & & & & & A & & & \\
\hline $199-\mathrm{N}-92 \mathrm{~A}$ & SURV & $100 \mathrm{~N}$ & & & & & & & & & & & & & & A & & & & & A & & & \\
\hline $199-N-96 A$ & CERC & 100NR2 & & & A & & A & & & & & & & Af & & A & & & & & A & & & \\
\hline 199-N-96A & SURV & $100 \mathrm{~N}$ & & & A & & & & & & & & & Af & & A & & & & & A & & & \\
\hline 199-N-99A & CERC & 100NR2 & & & A & & A & & & & & & & Af & & A & & & & & A & & & \\
\hline 199-N-99A & SURV & $100 \mathrm{~N}$ & & & & & & & & & & & & & & A & & & & & A & & & \\
\hline 299-E13-14 & $\mathrm{DOH}$ & 200E DOH & & A & A & & A & & & & A & & $\mathrm{A}$ & & & A & & & & & A & & & A:Puis \\
\hline 299-E13-14 & SURV & Central & & A & A & & A & & & A & A & & & Af & & A & & & & & A & A & & \\
\hline 299-E13-5 & $\mathrm{DOH}$ & 200E DOH & & A & A & & A & & & & A & & A & & & A & & & & & A & & & A:Puis \\
\hline
\end{tabular}




\begin{tabular}{|c|c|c|c|c|c|c|c|c|c|c|c|c|c|c|c|c|c|c|c|c|c|c|c|c|}
\hline WELL & PROG & PROJ & 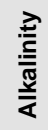 & $\frac{\frac{\pi}{0}}{\frac{0}{\alpha}}$ & $\frac{\mathscr{0}}{\frac{0}{c}}$ & 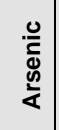 & 胥 & 屯ัँ & $\begin{array}{l}\frac{0}{0} \\
\frac{0}{5} \\
\text { ปे }\end{array}$ & 음 & 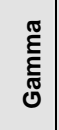 & $\begin{array}{l}\stackrel{0}{0} \\
\infty \\
\text { ㅁ }\end{array}$ & $\frac{\text { N }}{\underline{1}}$ & $\underline{0}$ & $\begin{array}{l}\frac{\infty}{0} \\
\frac{\sigma}{0} \\
\frac{5}{\alpha}\end{array}$ & $\begin{array}{l}\text { के } \\
\frac{1}{\omega}\end{array}$ & $\begin{array}{l}\stackrel{8}{\dot{d}} \\
\stackrel{0}{\circ}\end{array}$ & 里 & O & 암 & 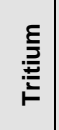 & 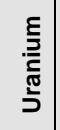 & § & Other/comments \\
\hline 299-E13-5 & SURV & Central & & A & A & & A & & & A & A & & A & Af & & A & & & & & A & & & \\
\hline 299-E16-1 & SURV & Basalt & $\mathrm{T}$ & $\mathrm{T}$ & $\mathrm{T}$ & & $\mathrm{T}$ & & & $\mathrm{T}$ & & & $\mathrm{T}$ & Tf & & & & & & & $\mathrm{T}$ & & & FY03. Elephant Mt interflow (b). \\
\hline 299-E16-2 & SURV & East & & & $\mathrm{T}$ & Tf & & & & $\mathrm{T}$ & & & $T$ & & & & & & & & $\mathrm{~T}$ & & & FY04 \\
\hline 299-E17-1 & RCRA & PUREX & $S$ & $S$ & $S$ & $\mathrm{Sf}$ & $S$ & & & & & & $S$ & $\mathrm{Sf}$ & $S$ & S & & & & & $S$ & & & S:Amm \\
\hline 299-E17-12 & SURV & East & & A & A & Af & $\mathrm{A}$ & & & A & & & $\mathrm{A}$ & Af & & & & & & & A & & & \\
\hline 299-E17-13 & SURV & East & A & A & A & Af & $A$ & & & A & & & $A$ & Af & & A & & & & & A & & & \\
\hline 299-E17-14 & RCRA & PUREX & $Q$ & $Q$ & $Q$ & Qf & $Q$ & & & & & & $Q$ & Qf & Q & $Q$ & & & & & $Q$ & & & Q:Amm \\
\hline 299-E17-14 & SURV & East & & & $\mathrm{T}$ & $\mathrm{Tf}$ & & & & $\mathrm{T}$ & & & $\mathrm{T}$ & & & & & & & & $\mathrm{T}$ & & & FY04 \\
\hline 299-E17-18 & RCRA & PUREX & $S$ & $S$ & $S$ & $\mathrm{Sf}$ & $S$ & & & & & & $S$ & $\mathrm{Sf}$ & $S$ & $\mathrm{~s}$ & & & & & $\mathrm{~s}$ & & & S:Amm \\
\hline 299-E17-18 & SURV & East & & & $\mathrm{T}$ & $\mathrm{Tf}$ & & & & $\mathrm{T}$ & & & $T$ & & & & & & & & $\mathrm{~T}$ & & & FY04 \\
\hline 299-E17-19 & RCRA & PUREX & $\mathrm{s}$ & $\mathrm{s}$ & $\mathrm{S}$ & $\mathrm{Sf}$ & $\mathrm{s}$ & & & & & & $S$ & $\mathrm{Sf}$ & $\mathrm{s}$ & $\mathrm{s}$ & & & & & $\mathrm{S}$ & & & S:Amm \\
\hline 299-E17-19 & SURV & East & & & $T$ & $\mathrm{Tf}$ & & & & $\mathrm{T}$ & & & $T$ & & & & & & & & $T$ & & & FY04 \\
\hline 299-E17-9 & RCRA & PUREX & $S$ & $S$ & $S$ & $\mathrm{Sf}$ & $S$ & & & & & & $S$ & $\mathrm{Sf}$ & $S$ & $S$ & & & & & $\mathrm{~S}$ & & & S:Amm \\
\hline 299-E17-9 & SURV & East & & & $T$ & $\mathrm{Tf}$ & & & & $\mathrm{T}$ & & & $T$ & & & & & & & & $T$ & & & FY04 \\
\hline 299-E18-1 & SURV & Central & & & $\mathrm{T}$ & Tf & & & & $\mathrm{T}$ & & & $\mathrm{T}$ & $\mathrm{Tf}$ & & & & & & & $\mathrm{T}$ & & & FY04 \\
\hline 299-E23-1 & SURV & East & & & $\mathrm{T}$ & $\mathrm{Tf}$ & & & & $\mathrm{T}$ & & & $T$ & & & & & & & & $T$ & & & FY04 \\
\hline 299-E24-16 & RCRA & PUREX & Q & Q & $Q$ & Qf & Q & & & & & & Q & Qf & Q & Q & & & & & Q & & & Q:Amm \\
\hline 299-E24-18 & RCRA & PUREX & S & S & $S$ & $\mathrm{Sf}$ & S & & & & & & $S$ & $\mathrm{Sf}$ & $S$ & $\mathrm{~s}$ & & & & & $S$ & & & S:Amm \\
\hline 299-E24-18 & SURV & East & & & $T$ & Tf & & & & $\mathrm{T}$ & & & $T$ & & & & & & & & $T$ & & & FY04 \\
\hline 299-E24-19 & RCRA & SST(A) & $S$ & & $S$ & & $A$ & & & & $S$ & & A & $\mathrm{Sf}$ & A & A & $S$ & & S4 & S4 & $A$ & $S$ & & \\
\hline 299-E24-19 & SURV & East & & $A$ & A & & $A$ & & & $A$ & & & & & & & & & & & & & & \\
\hline 299-E24-20 & RCRA & SST $(A)$ & $S$ & & $S$ & & A & & & & $S$ & & $\mathrm{~A}$ & $\mathrm{Sf}$ & A & A & $S$ & & S4 & S4 & $\mathrm{A}$ & $S$ & & \\
\hline 299-E24-20 & SURV & East & & & $\mathrm{T}$ & $\mathrm{Tf}$ & & & & $\mathrm{T}$ & & & $T$ & & & & & & & & $\mathrm{~T}$ & & & FY04 \\
\hline 299-E24-5 & SURV & East & & & $T$ & Tf & & & & $\mathrm{T}$ & & & $T$ & & & & & & & & $T$ & & & FY04 \\
\hline 299-E24-8 & SURV & East & & $\mathrm{T}$ & $\mathrm{T}$ & $\mathrm{Tf}$ & $\mathrm{T}$ & & & $\mathrm{T}$ & $T$ & & $T$ & & & & & & & & $\mathrm{~T}$ & & & FY04 \\
\hline 299-E25-17 & RCRA & PUREX & $S$ & $S$ & $S$ & $\mathrm{Sf}$ & $S$ & & & & & & $S$ & $\mathrm{Sf}$ & $S$ & $S$ & & & & & $S$ & & & S: Amm \\
\hline 299-E25-17 & SURV & East & & & $T$ & $\mathrm{Tf}$ & & & & $\mathrm{T}$ & & & $T$ & & & & & & & & $\mathrm{~T}$ & & & FY04 \\
\hline 299-E25-18 & SURV & East & & & $\mathrm{T}$ & Tf & & & & $\mathrm{T}$ & & & $T$ & & & & & & & & $T$ & & & FY04 \\
\hline 299-E25-19 & RCRA & PUREX & $Q$ & $Q$ & $Q$ & Qf & $Q$ & & & & & & $Q$ & Qf & Q & Q & & & & & $Q$ & & & Q:Amm \\
\hline 299-E25-19 & SURV & East & & & $\mathrm{T}$ & $\mathrm{Tf}$ & & & & $\mathrm{T}$ & & & $T$ & & & & & & & & $\mathrm{~T}$ & & & FY04 \\
\hline 299-E25-20 & SURV & East & & & $\mathrm{T}$ & Tf & & & & $\mathrm{T}$ & & & $\mathrm{T}$ & & & & & & & & $\mathrm{T}$ & & & FY04 \\
\hline
\end{tabular}




\begin{tabular}{|c|c|c|c|c|c|c|c|c|c|c|c|c|c|c|c|c|c|c|c|c|c|c|c|c|}
\hline WELL & PROG & PROJ & 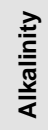 & $\frac{\frac{\pi}{0}}{\frac{0}{\alpha}}$ & $\frac{\mathscr{0}}{\frac{0}{c}}$ & 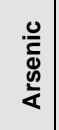 & 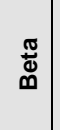 & 屯ัँ & $\begin{array}{l}\frac{0}{0} \\
\frac{0}{5} \\
\text { ปे }\end{array}$ & 음 & 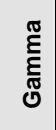 & $\begin{array}{l}\stackrel{0}{0} \\
\infty \\
\text { ㅁ }\end{array}$ & $\frac{\text { N }}{\underline{1}}$ & $\underline{0}$ & $\begin{array}{l}\frac{\infty}{0} \\
\frac{\sigma}{0} \\
\frac{5}{\alpha}\end{array}$ & $\begin{array}{l}\frac{8}{0} \\
\frac{1}{5}\end{array}$ & 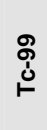 & $\stackrel{\text { 足 }}{口}$ & O & 음 & 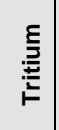 & 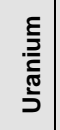 & ঠ̊ & Other/comments \\
\hline 299-E25-22 & SURV & East & & & $\mathrm{T}$ & Tf & & & & $\mathrm{T}$ & & & $\mathrm{T}$ & & & & & & & & $\mathrm{T}$ & & & FY04 \\
\hline 299-E25-26 & RCRA & A-29 & $\mathrm{s}$ & & $\mathrm{S}$ & & & & & & & & & Af & A & & & & S4 & S4 & & & & \\
\hline 299-E25-28 & RCRA & A-29 & $\mathrm{s}$ & & $\mathrm{s}$ & & & & & & & & & Af & A & & & & A4 & A4 & & & & Deep unconfined. \\
\hline 299-E25-28 & SURV & East & & & $T$ & Tf & & & & $T$ & & & $T$ & & & & & & & & $T$ & & & FY04. Deep unconfined. \\
\hline 299-E25-29P & SURV & East & & & $\mathrm{T}$ & $\mathrm{Tf}$ & & & & $\mathrm{T}$ & & & $\mathrm{T}$ & & & & & & & & $\mathrm{T}$ & & & FY04 \\
\hline 299-E25-29Q & SURV & East & & & $T$ & $\mathrm{Tf}$ & & & & $T$ & & & $T$ & & & & & & & & $T$ & & & FY04 \\
\hline 299-E25-3 & SURV & East & & & $T$ & Tf & & & & $T$ & & & $T$ & & & & & & & & $\bar{T}$ & & & FY04 \\
\hline 299-E25-31 & RCRA & PUREX & $S$ & $S$ & $S$ & $\mathrm{Sf}$ & $S$ & & & & & & $S$ & $\mathrm{Sf}$ & $S$ & $S$ & & & & & $S$ & & & S:Amm \\
\hline 299-E25-32P & RCRA & A-29 & S & & $\mathrm{s}$ & & & & & & & & & Af & A & & & & S4 & S4 & & & & \\
\hline 299-E25-32P & SURV & East & & & $\mathrm{T}$ & $\mathrm{Tf}$ & & & & $\mathrm{T}$ & & & $\mathrm{T}$ & & & & & & & & $\mathrm{T}$ & & & FY04 \\
\hline 299-E25-32Q & SURV & East & $T$ & & $T$ & Tf & & & & $\mathrm{T}$ & & & $\mathrm{T}$ & Tf & & & & & & & $T$ & & & FY04. \\
\hline 299-E25-34 & RCRA & A-29 & $\mathrm{s}$ & & $\mathrm{s}$ & & & & & & & & & Af & A & & & & S4 & S4 & & & & \\
\hline 299-E25-34 & SURV & East & & & $\mathrm{T}$ & $\mathrm{Tf}$ & & & & $\mathrm{T}$ & & & $T$ & & & & & & & & $\mathrm{~T}$ & & & FY04 \\
\hline 299-E25-35 & RCRA & A-29 & $S$ & & $S$ & & & & & & & & & Af & A & & & & S4 & S4 & & & & \\
\hline 299-E25-35 & SURV & East & & & $\mathrm{T}$ & $\mathrm{Tf}$ & & & & $\mathrm{T}$ & & & $\mathrm{T}$ & & & & & & & & $\mathrm{T}$ & & & FY04 \\
\hline 299-E25-36 & SURV & East & & & $\mathrm{T}$ & $\mathrm{Tf}$ & & & & $\mathrm{T}$ & & & $T$ & & & & & & & & $T$ & & & FY04 \\
\hline \begin{tabular}{|l|}
$299-E 25-37$ \\
\end{tabular} & SURV & East & & & $T$ & $\mathrm{Tf}$ & & & & $\mathrm{T}$ & & & $T$ & & & & & & & & $\mathrm{~T}$ & & & FY04 \\
\hline 299-E25-39 & SURV & East & & & A & $\mathrm{Af}$ & & & & & & & $\mathrm{A}$ & & & & & & & & $\mathrm{A}$ & & & \\
\hline 299-E25-40 & RCRA & SST $(A)$ & $S$ & & $\mathrm{~s}$ & & $A$ & & & & $S$ & & $A$ & $\mathrm{Sf}$ & $A$ & A & $S$ & & S4 & S4 & $A$ & $S$ & & \\
\hline 299-E25-41 & RCRA & SST(A) & $S$ & & $S$ & & $A$ & & & & $S$ & & A & $\mathrm{Sf}$ & A & $A$ & $S$ & & S4 & S4 & $A$ & $S$ & & \\
\hline 299-E25-41 & SURV & East & & & $T$ & Tf & & & & $T$ & & & $T$ & & & & & & & & $T$ & & & FY04 \\
\hline 299-E25-42 & SURV & East & & & $\mathrm{T}$ & Tf & & & & $\mathrm{T}$ & & & $T$ & & & & & & & & $\mathrm{~T}$ & & & FY04 \\
\hline 299-E25-43 & SURV & East & & & $\mathrm{T}$ & & & & & $\mathrm{T}$ & & & $T$ & & & & & & & & $\mathrm{~T}$ & & & FY04 \\
\hline 299-E25-44 & SURV & East & & & & & & & & $\mathrm{T}$ & & & $\mathrm{T}$ & & & & & & & & $T$ & & & FY04 \\
\hline 299-E25-46 & RCRA & $\operatorname{SST}(\mathrm{A})$ & $S$ & & $S$ & & $A$ & & & & $S$ & & $A$ & $\mathrm{Sf}$ & $A$ & $A$ & $S$ & & S4 & S4 & $\mathrm{A}$ & $S$ & & \\
\hline 299-E25-46 & SURV & East & & & $T$ & & & & & $\mathrm{~T}$ & & & $T$ & & & & & & & & $T$ & & & FY04 \\
\hline 299-E25-47 & SURV & East & & & $T$ & & & & & $\mathrm{~T}$ & & & $T$ & & & & & & & & $\mathrm{~T}$ & & & FY04 \\
\hline 299-E25-48 & RCRA & A-29 & $S$ & & $\mathrm{~s}$ & & & & & & & & & Af & $A$ & & & & S4 & S4 & & & & \\
\hline 299-E25-6 & SURV & East & & $\mathrm{T}$ & $T$ & $\mathrm{Tf}$ & $\mathrm{T}$ & & & $\mathrm{T}$ & $T$ & & $\mathrm{~T}$ & & & & $\mathrm{~T}$ & & & & $T$ & $\mathrm{~T}$ & & FY04 \\
\hline 299-E26-10 & RCRA & LERF & A & $\mathrm{s}$ & $\mathrm{s}$ & $\mathrm{Af}$ & $S$ & & & & & & & $\mathrm{Sf}$ & $A$ & & A & & & & A & & $\mathrm{s}$ & S:Amm \\
\hline 299-E26-10 & SURV & Central & & & $A$ & Af & & & & A & & & $A$ & & & & & & & & $A$ & & & \\
\hline
\end{tabular}




\begin{tabular}{|c|c|c|c|c|c|c|c|c|c|c|c|c|c|c|c|c|c|c|c|c|c|c|c|c|}
\hline WELL & PROG & PROJ & 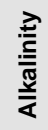 & $\frac{\frac{\pi}{0}}{\frac{0}{\alpha}}$ & $\frac{\mathscr{0}}{\frac{0}{c}}$ & 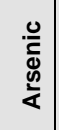 & 胥 & 屯ัँ & 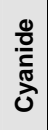 & 웅 & 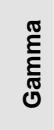 & $\begin{array}{l}0 \\
0 \\
\infty \\
\text { ㅇ }\end{array}$ & $\stackrel{\text { ని }}{\underline{I}}$ & $\underline{0}$ & $\begin{array}{l}\frac{\infty}{0} \\
\frac{\sigma}{0} \\
\frac{5}{\alpha}\end{array}$ & $\begin{array}{l}\frac{8}{0} \\
\frac{1}{5}\end{array}$ & $\begin{array}{l}\text { : } \\
\text { ㅇ }\end{array}$ & $\stackrel{\text { 足 }}{口}$ & O & 음 & 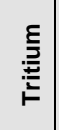 & 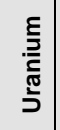 & § & Other/comments \\
\hline 299-E26-11 & RCRA & LERF & A & $S$ & A & & $S$ & & & & & & & Af & A & & & & & & & & $\mathrm{s}$ & S:Amm \\
\hline 299-E26-11 & SURV & Central & & & $\mathrm{T}$ & $\mathrm{Tf}$ & & & & $\mathrm{T}$ & & & $T$ & & & & & & & & $T$ & & & FY04 \\
\hline 299-E26-12 & RCRA & A-29 & $S$ & & $\mathrm{~s}$ & & & & & & & & & Af & A & & & & S4 & S4 & & & & \\
\hline 299-E26-13 & RCRA & A-29 & $S$ & & $S$ & & & & & & & & & Af & A & & & & S4 & S4 & & & & \\
\hline 299-E26-4 & SURV & East & & A & A & Af & $A$ & & & A & A & & A & Af & & & & & & & A & & & \\
\hline 299-E26-8 & SURV & Basalt & $\mathrm{T}$ & $\mathrm{T}$ & $\mathrm{T}$ & & $\mathrm{T}$ & & & $\mathrm{T}$ & & & $\mathrm{T}$ & Tf & & & & & & & $\mathrm{T}$ & & & $\begin{array}{l}\text { FY03. Rattlesnake Ridge } \\
\text { Interbed (b). }\end{array}$ \\
\hline 299-E27-10 & RCRA & LLBG(2) & $\mathrm{s}$ & $\mathrm{s}$ & $\mathrm{s}$ & & $\mathrm{s}$ & & & & & $\mathrm{Sf}$ & & $\mathrm{Sf}$ & A & & & & S4 & S4 & $\mathrm{s}$ & & & S:PCB \\
\hline 299-E27-10 & SURV & Central & & & $T$ & $\mathrm{Tf}$ & & & & $\mathrm{T}$ & & & $T$ & & & & & & & & $T$ & & & FY04 \\
\hline 299-E27-11 & RCRA & B-63 & A & $S$ & A & & $S$ & & & & & & & Af & A & & & & S4 & S4 & & & & \\
\hline 299-E27-11 & RCRA & LLBG(2) & $S$ & $\mathrm{~s}$ & $\mathrm{~s}$ & & $\mathrm{~s}$ & & & & & $\mathrm{Sf}$ & & $\mathrm{Sf}$ & $\mathrm{A}$ & & & & S4 & S4 & $S$ & & & S:PCB \\
\hline 299-E27-12 & RCRA & $\mathrm{SST}(\mathrm{C})$ & Q & & $Q$ & & & & $Q$ & & $Q$ & & & Qf & $\mathrm{A}$ & & $Q$ & $Q$ & Q4 & Q4 & & A & & \\
\hline 299-E27-13 & RCRA & SST(C) & $Q$ & & $Q$ & & & & $Q$ & & $Q$ & & & Qf & $\mathrm{A}$ & & Q & $Q$ & Q4 & Q4 & & $\mathrm{A}$ & & \\
\hline 299-E27-14 & RCRA & $\mathrm{SST}(\mathrm{C})$ & $Q$ & & $Q$ & & & & $Q$ & & $Q$ & & & Qf & $A$ & & $Q$ & $Q$ & Q4 & Q4 & & A & & \\
\hline 299-E27-14 & SURV & Central & & & $\mathrm{T}$ & $\mathrm{Tf}$ & & & & $\mathrm{T}$ & & & $T$ & & & & & & & & $T$ & & & FY04 \\
\hline 299-E27-15 & RCRA & SST(C) & $Q$ & & $Q$ & & & & $Q$ & & $\mathrm{Q}$ & & & Qf & A & & $Q$ & $Q$ & Q4 & Q4 & & A & & \\
\hline 299-E27-15 & SURV & East & & A & $\mathrm{A}$ & & A & & & A & & & & Af & & & A & & & & & & & \\
\hline 299-E27-16 & RCRA & B-63 & $A$ & $\mathrm{~s}$ & A & & $\mathrm{S}$ & & & & & & & Af & $A$ & & & & S4 & S4 & & & & \\
\hline 299-E27-17 & RCRA & B-63 & A & $\mathrm{s}$ & A & & $S$ & & & & & & & Af & A & & & & S4 & S4 & & & & \\
\hline \begin{tabular}{|l|}
$299-E 27-17$ \\
\end{tabular} & RCRA & LLBG(2) & $S$ & $\mathrm{~S}$ & $\mathrm{~s}$ & & $S$ & & & & & $\mathrm{Sf}$ & & $\mathrm{Sf}$ & A & & & & S4 & S4 & $\mathrm{s}$ & & & S:PCB \\
\hline 299-E27-17 & SURV & Central & & & $\mathrm{T}$ & Tf & & & & $\mathrm{T}$ & & & $T$ & & & & & & & & $\mathrm{~T}$ & & & FY04 \\
\hline 299-E27-18 & RCRA & B-63 & $\mathrm{A}$ & $S$ & $\mathrm{~A}$ & & $S$ & & & & & & & Af & $\mathrm{A}$ & & & & S4 & S4 & & & & \\
\hline 299-E27-18 & SURV & Central & & & $T$ & $\mathrm{Tf}$ & & & & $T$ & & & $T$ & & & & & & & & $T$ & & & FY04 \\
\hline 299-E27-19 & RCRA & B-63 & $A$ & $\mathrm{~s}$ & A & & $S$ & & & & & & & Af & $A$ & & & & S4 & S4 & & & & \\
\hline \begin{tabular}{|l|}
$299-E 27-7$ \\
\end{tabular} & RCRA & SST(C) & $Q$ & & $Q$ & & & & $Q$ & & $Q$ & & & Qf & $A$ & & $Q$ & $Q$ & Q4 & Q4 & & A & & \\
\hline 299-E27-7 & SURV & East & & & $\mathrm{T}$ & $\mathrm{Tf}$ & & & & $\mathrm{T}$ & & & $T$ & & & & $\mathrm{~T}$ & & & & $\mathrm{~T}$ & & & FY04 \\
\hline 299-E27-8 & RCRA & B-63 & $\mathrm{A}$ & $S$ & A & & $S$ & & & & & & & Af & A & & & & S4 & S4 & & & & \\
\hline 299-E27-8 & RCRA & LLBG(2) & $\mathrm{s}$ & $\mathrm{S}$ & $\mathrm{s}$ & & $\mathrm{s}$ & & & & & $\mathrm{Sf}$ & & $\mathrm{Sf}$ & $\mathrm{A}$ & & & & S4 & S4 & $S$ & & & S:PCB \\
\hline 299-E27-9 & RCRA & B-63 & $A$ & $\mathrm{~s}$ & A & & $\mathrm{s}$ & & & & & & & Af & A & & & & S4 & S4 & & & & \\
\hline 299-E27-9 & RCRA & LLBG(2) & $\mathrm{s}$ & $\mathrm{s}$ & $\mathrm{s}$ & & $\mathrm{s}$ & & & & & $\mathrm{Sf}$ & & $\mathrm{Sf}$ & A & & & & S4 & S4 & $\mathrm{s}$ & & & S:PCB \\
\hline 299-E28-13 & SURV & Central & & $\mathrm{T}$ & $T$ & Tf & $\mathrm{T}$ & & & $\mathrm{T}$ & & & $T$ & & & & & & & & $T$ & $T$ & & FY04 \\
\hline
\end{tabular}




\begin{tabular}{|c|c|c|c|c|c|c|c|c|c|c|c|c|c|c|c|c|c|c|c|c|c|c|c|c|}
\hline WELL & PROG & PROJ & 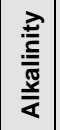 & $\frac{\frac{\pi}{0}}{\frac{0}{\alpha}}$ & $\begin{array}{l}\frac{n}{2} \\
\frac{0}{\frac{L}{L}}\end{array}$ & 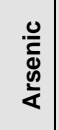 & 丞 & $\begin{array}{l}+ \\
\text { ப் }\end{array}$ & $\begin{array}{l}\frac{0}{0} \\
\frac{0}{\bar{J}} \\
\text { ठ̀ }\end{array}$ & 음 & $\begin{array}{l}\text { हू } \\
\text { हू } \\
\text { ઠ }\end{array}$ & $\begin{array}{l}0 \\
\alpha \\
\infty \\
\text { వ } \\
\text { I }\end{array}$ & $\stackrel{\text { ని }}{\underline{I}}$ & $\underline{0}$ & $\begin{array}{l}\frac{0}{0} \\
\frac{0}{0} \\
\frac{5}{\alpha}\end{array}$ & $\begin{array}{l}8 \\
\frac{1}{\omega} \\
\frac{1}{\infty}\end{array}$ & $\begin{array}{l}\stackrel{8}{P} \\
\dot{0}\end{array}$ & $\stackrel{\text { 足 }}{口}$ & $\begin{array}{l}0 \\
\stackrel{\circ}{\prime}\end{array}$ & 임 & 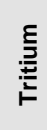 & 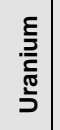 & §̊ & Other/comments \\
\hline 299-E28-17 & SURV & Central & A & & A & Af & A & & & A & A & & A & Af & & A & & & & & A & A & & \\
\hline 299-E28-18 & LTMC & 200BP5 & & & & & & & & & & & & & & & & & & & & A & & \\
\hline 299-E28-18 & SURV & Central & & & A & Af & A & & & A & & & A & & & & & & & & A & A & & \\
\hline 299-E28-2 & LTMC & 200BP5 & & & & & & & & & $A$ & & & & & $A$ & & & & & & & & A:Puis \\
\hline 299-E28-2 & SURV & Central & $\mathrm{A}$ & A & A & Af & A & & & A & A & & $A$ & Af & & $\mathrm{A}$ & A & & & & A & & & A:Puis \\
\hline 299-E28-23 & LTMC & 200BP5 & & & & & & & & & A & & & & & A & & & & & & & & A:Puis \\
\hline 299-E28-23 & SURV & Central & & A & & & A & & & A & Af/u & & & & & Af/u & & & & & & A & & A:Puis f/u Am Np Uiso \\
\hline 299-E28-24 & LTMC & 200BP5 & & & & & & & & & A & & & & & A & & & & & & & & A:Puis \\
\hline 299-E28-24 & SURV & Central & & A & & & A & & & A & Af/u & & & & & $\mathrm{Af} / \mathrm{u}$ & & & & & A & A & & A:Puis f/u Am Np Uiso \\
\hline 299-E28-25 & LTMC & 200BP5 & & & & & & & & & A & & & & & $A$ & & & & & & & & A:Puis \\
\hline 299-E28-25 & SURV & Central & & A & A & Af & $A$ & & & $A$ & Af/u & & $A$ & & & Af/u & & & & & A & A & & A:Puis f/u Am Np Uiso \\
\hline 299-E28-26 & RCRA & LLBG(1) & $S$ & & $\mathrm{~s}$ & & $\mathrm{~S}$ & & & & & $\mathrm{Sf}$ & & $\mathrm{Sf}$ & A & & & & S4 & S4 & $\mathrm{s}$ & $\mathrm{s}$ & & \\
\hline 299-E28-26 & RCRA & SST(B) & & $S$ & & & & & $S$ & & & & & & & & $S$ & & & & & & & \\
\hline 299-E28-26 & SURV & Central & & & $\mathrm{T}$ & $\mathrm{Tf}$ & & & & $\mathrm{T}$ & & & $\mathrm{T}$ & & & & & & & & $\mathrm{T}$ & & & FY04 \\
\hline 299-E28-27 & RCRA & LLBG(1) & $S$ & & $\mathrm{~s}$ & & $S$ & & & & & $\mathrm{Sf}$ & & $\mathrm{Sf}$ & $A$ & & & & S4 & S4 & $S$ & $S$ & & \\
\hline 299-E28-27 & RCRA & SST(B) & & & & & & & $S$ & & & & & & & & $\mathrm{~s}$ & & & & & & & \\
\hline 299-E28-27 & SURV & Central & & & $T$ & Tf & & & & $T$ & & & $T$ & & & & & & & & $\mathrm{~T}$ & & & FY04 \\
\hline 299-E28-28 & RCRA & LLBG(1) & $S$ & & $\mathrm{~s}$ & & $S$ & & & & & $\mathrm{Sf}$ & & $\mathrm{Sf}$ & A & & & & S4 & S4 & $\mathrm{s}$ & $S$ & & \\
\hline 299-E28-28 & RCRA & SST(B) & & & & & & & $A$ & & & & & & & & A & & & & & & & \\
\hline 299-E28-28 & SURV & Central & & & $\mathrm{T}$ & & & & & $T$ & & & $T$ & & & & & & & & $T$ & & & FY04 \\
\hline 299-E28-5 & SURV & Central & & $T$ & $T$ & Tf & $T$ & & & $T$ & $T$ & & $T$ & & & $T$ & & & & & $T$ & $T$ & & FY04. T:Am Np Puis \\
\hline 299-E28-6 & SURV & Central & & $\mathrm{T}$ & $\mathrm{T}$ & $\mathrm{Tf}$ & $T$ & & & $\mathrm{~T}$ & $\mathrm{~T}$ & & $\mathrm{~T}$ & & & $\mathrm{~T}$ & & & & & $\mathrm{~T}$ & $\mathrm{~T}$ & & FY04. T:Puis \\
\hline 299-E28-8 & LTMC & 200BP5 & & & & & & & & & & & & & & & A & & & & & & & \\
\hline 299-E28-8 & RCRA & SST(B) & $\mathrm{A}$ & & A & & & & $A$ & & A & & & Af & & & A & & & & A & A & & \\
\hline 299-E28-8 & SURV & Central & & & A & & & & & A & $\mathrm{A}$ & & & & & $A$ & A & & & & & A & & A:Puis, Uis \\
\hline 299-E32-10 & RCRA & LLBG(1) & $S$ & & $\mathrm{~s}$ & & $S$ & & & & & $\mathrm{Sf}$ & & $\mathrm{Sf}$ & A & & & & S4 & S4 & $S$ & $\mathrm{~s}$ & & \\
\hline 299-E32-10 & RCRA & SST(B) & S & & S & & & & $Q$ & & $Q$ & & & $\mathrm{Sf}$ & & & $\mathrm{Q}$ & & & & S & & & \\
\hline 299-E32-10 & SURV & Central & & & $\mathrm{T}$ & Tf & $T$ & & $\mathrm{~T}$ & $T$ & $\mathrm{~T}$ & & $T$ & & & & $\mathrm{~T}$ & & & & $\mathrm{~T}$ & $T$ & & FY04 \\
\hline 299-E32-2 & RCRA & LLBG(1) & $S$ & & $\mathrm{~S}$ & & $S$ & & & & & $\mathrm{Sf}$ & & $\mathrm{Sf}$ & A & & & & S4 & S4 & $\mathrm{s}$ & $\mathrm{S}$ & & \\
\hline 299-E32-2 & RCRA & SST(B) & & & & & & & $S$ & & & & & & & & $S$ & & & & & & & \\
\hline 299-E32-2 & SURV & Central & & & $T$ & & & & & $\mathrm{~T}$ & & & $T$ & & & & & & & & $\mathrm{~T}$ & & & FY04 \\
\hline
\end{tabular}




\begin{tabular}{|c|c|c|c|c|c|c|c|c|c|c|c|c|c|c|c|c|c|c|c|c|c|c|c|c|}
\hline WELL & PROG & PROJ & 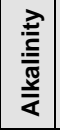 & $\frac{\pi}{\frac{0}{0}}$ & $\frac{n}{\frac{0}{c}}$ & 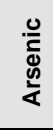 & $\begin{array}{l}\text { Фँ } \\
\text { Ф }\end{array}$ & 屯े & 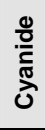 & 움 & 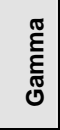 & $\begin{array}{l}\text { 웅 } \\
\infty \\
\text { 옴 }\end{array}$ & $\frac{\text { N }}{1}$ & 음 & $\begin{array}{l}\frac{\infty}{0} \\
\frac{0}{\Phi} \\
\frac{\pi}{\alpha}\end{array}$ & $\begin{array}{l}\text { के } \\
\frac{1}{\omega}\end{array}$ & $\begin{array}{l}\text { O̊d } \\
\text { i }\end{array}$ & $\stackrel{\mathscr{P}}{口}$ & 옴 & 음 & 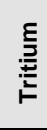 & 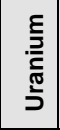 & $\stackrel{\nwarrow}{\supset}$ & Other/comments \\
\hline 299-E32-3 & RCRA & LLBG(1) & 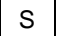 & & $S$ & & $\mathrm{~S}$ & & & & & $\mathrm{Sf}$ & & $\mathrm{Sf}$ & A & & & & S4 & S4 & $S$ & $S$ & & \\
\hline 299-E32-3 & RCRA & SST(B) & & & & & & & $S$ & & & & & & & & $S$ & & & & & & & \\
\hline 299-E32-4 & RCRA & LLBG(1) & $\mathrm{s}$ & & $\mathrm{s}$ & & S & & & & & $\mathrm{Sf}$ & & $\mathrm{Sf}$ & A & & & & S4 & S4 & $\mathrm{s}$ & $\mathrm{s}$ & & \\
\hline 299-E32-4 & RCRA & SST(B) & & & & & & & $S$ & & & & & & & & $S$ & & & & & & & \\
\hline 299-E32-4 & SURV & Central & & & $\mathrm{T}$ & & & & & $\mathrm{T}$ & & & $\mathrm{T}$ & & & & & & & & $\mathrm{T}$ & & & FY04 \\
\hline 299-E32-5 & RCRA & LLBG(1) & 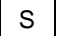 & & $\mathrm{s}$ & & $S$ & & & & & $\mathrm{Sf}$ & & $\mathrm{Sf}$ & A & & & & S4 & S4 & $S$ & $S$ & & \\
\hline 299-E32-5 & RCRA & SST(B) & & & & & & & $S$ & & & & & & & & $S$ & & & & & & & \\
\hline 299-E32-5 & SURV & Central & & & T & & & & & $\mathrm{T}$ & & & $\mathrm{T}$ & & & & & & & & $\mathrm{T}$ & $\mathrm{T}$ & & FY04 \\
\hline 299-E32-6 & RCRA & $\operatorname{LLBG}(1)$ & $S$ & & $S$ & & $S$ & & & & & $\mathrm{Sf}$ & & $\mathrm{Sf}$ & A & & & & S4 & S4 & S & $S$ & & \\
\hline 299-E32-6 & RCRA & SST(B) & & & & & & & s & & & & & & & & S & & & & & & & \\
\hline 299-E32-6 & SURV & Central & & & $\mathrm{T}$ & & & & & T & & & $\mathrm{T}$ & & & & & & & & $\mathrm{T}$ & $\mathrm{T}$ & & FY04 \\
\hline 299-E32-7 & RCRA & $\operatorname{LLBG}(1)$ & $\mathrm{s}$ & & $\mathrm{s}$ & & $\mathrm{s}$ & & & & & $\mathrm{Sf}$ & & $\mathrm{Sf}$ & A & & & & S4 & S4 & 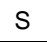 & $\mathrm{s}$ & & \\
\hline 299-E32-7 & RCRA & SST(B) & & & & & & & s & & & & & & & & S & & & & & & & \\
\hline 299-E32-7 & SURV & Central & & & $\mathrm{T}$ & & & & & $\mathrm{T}$ & & & $\mathrm{T}$ & & & & & & & & $\mathrm{T}$ & & & FY04 \\
\hline 299-E32-8 & RCRA & $\operatorname{LLBG}(1)$ & s & & $S$ & & s & & & & & $\mathrm{Sf}$ & & $\mathrm{Sf}$ & A & & & & S4 & S4 & $S$ & s & & \\
\hline 299-E32-8 & RCRA & SST(B) & & & & & & & s & & & & & & & & s & & & & & & & \\
\hline 299-E32-8 & SURV & Central & & & $\mathrm{T}$ & & & & & $\mathrm{T}$ & & & $\mathrm{T}$ & & & & & & & & $\mathrm{T}$ & & & FY04 \\
\hline 299-E32-9 & LTMC & 200BP5 & & & & & & & & & & & & & & & A & & & & & & & \\
\hline 299-E32-9 & RCRA & $\operatorname{LLBG}(1)$ & $\mathrm{s}$ & & $\mathrm{s}$ & & $S$ & & & & & $\mathrm{Sf}$ & & $\mathrm{Sf}$ & A & & & & S4 & S4 & $\mathrm{s}$ & S & & \\
\hline 299-E32-9 & RCRA & SST(B) & & & & & & & s & & & & & & & & S & & & & & & & \\
\hline 299-E32-9 & SURV & Central & & & $\mathrm{T}$ & & & & $\mathrm{T}$ & $\mathrm{T}$ & & & $\mathrm{T}$ & & & & & & & & $\mathrm{T}$ & & & FY04 \\
\hline 299-E33-12 & LTMC & 200BP5 & & & & & & & & & & & & & & & $\mathrm{T}$ & & & & & & & \\
\hline 299-E33-12 & SURV & Basalt & $\mathrm{T}$ & $\mathrm{T}$ & $\mathrm{T}$ & & $\mathrm{T}$ & & $\mathrm{T}$ & $\mathrm{T}$ & $\mathrm{T}$ & & $\mathrm{T}$ & Tf & & & $\mathrm{T}$ & & & & $\mathrm{T}$ & $\mathrm{T}$ & & $\begin{array}{l}\text { FY04. Rattlesnake Ridge } \\
\text { Interbed (b). }\end{array}$ \\
\hline 299-E33-13 & LTMC & 200BP5 & & & A & & & & A & & A & & & & & & A & & & & & & & \\
\hline 299-E33-13 & SURV & Central & & & A & Af & & & A & A & A & & A & & & & A & & & & A & $\mathrm{Af} / \mathrm{u}$ & & A:Uiso, Np \\
\hline 299-E33-15 & RCRA & SST(B) & A & & $S$ & & & & $S$ & & $S$ & & & $\mathrm{Sf}$ & & & $S$ & & & & $S$ & S & & \\
\hline 299-E33-16 & LTMC & 200BP5 & & & A & & & & & & & & & & & & A & & & & & & & \\
\hline 299-E33-16 & RCRA & SST(B) & A & & $S$ & & & & $S$ & & $\mathrm{~S}$ & & & $\mathrm{Sf}$ & & & $S$ & & & & $S$ & $S$ & & \\
\hline 299-E33-17 & RCRA & SST(B) & A & & $S$ & & & & $S$ & & A & & & $\mathrm{Sf}$ & & & $S$ & & & & $S$ & $\mathrm{~s}$ & & \\
\hline 299-E33-18 & RCRA & SST(B) & $\mathrm{Q}$ & Q & Q & & Q & & Q & & S & & & Qf & & & Q & & & & Q & Q & & \\
\hline
\end{tabular}




\begin{tabular}{|c|c|c|c|c|c|c|c|c|c|c|c|c|c|c|c|c|c|c|c|c|c|c|c|c|}
\hline WELL & PROG & PROJ & 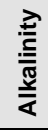 & $\frac{\frac{\pi}{0}}{\frac{0}{\alpha}}$ & $\frac{\mathscr{0}}{\frac{0}{\pi}}$ & 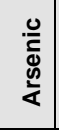 & Фూ & $\begin{array}{l}+ \\
\text { ஸे }\end{array}$ & 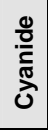 & 웅 & 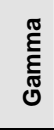 & $\begin{array}{l}0 \\
\infty \\
\infty \\
\text { ㅁ }\end{array}$ & $\underset{\frac{N}{1}}{1}$ & $\stackrel{0}{0}$ & $\begin{array}{l}\frac{\infty}{0} \\
\frac{\Phi}{\Phi} \\
\frac{\hbar}{\alpha}\end{array}$ & $\begin{array}{l}\text { के } \\
\frac{1}{\omega}\end{array}$ & $\begin{array}{l}\stackrel{8}{\dot{d}} \\
\stackrel{0}{\circ}\end{array}$ & 足 & 암 & 옴 & 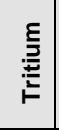 & 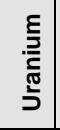 & § & Other/comments \\
\hline 299-E33-20 & RCRA & SST(B) & A & & $S$ & & & & $S$ & & A & & & $\mathrm{Sf}$ & & & 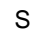 & & & & $S$ & $S$ & & \\
\hline 299-E33-21 & RCRA & SST(B) & A & & $S$ & & & & $S$ & & A & & & $\mathrm{Sf}$ & & & $s$ & & & & $S$ & $S$ & & \\
\hline 299-E33-26 & LTMC & 200BP5 & & & & & & & A & & A & & & & & & A & & & & & & & \\
\hline 299-Е33-26 & RCRA & SST(B) & Q & & Q & & Q & & Q & & Q & & & Qf & & & Q & & & & Q & Q & & \\
\hline 299-E33-26 & SURV & Central & & $\mathrm{T}$ & $\mathrm{T}$ & & $\mathrm{T}$ & & $\mathrm{T}$ & $\mathrm{T}$ & $\mathrm{T}$ & & $\mathrm{T}$ & & & & $\mathrm{T}$ & & & & $\mathrm{T}$ & $\mathrm{T}$ & & FY04 \\
\hline 299-E33-28 & RCRA & $\operatorname{LLBG}(1)$ & S & & $S$ & & $S$ & & & & & $\mathrm{Sf}$ & & $\mathrm{Sf}$ & A & & & & S4 & S4 & $S$ & $S$ & & \\
\hline 299-E33-28 & RCRA & SST(B) & $S$ & & $S$ & & & & Q & & & & & $\mathrm{Sf}$ & & & Q & & & & $S$ & & & \\
\hline 299-Е33-29 & LTMC & 200BP5 & & & A & & & & & & & & & & & & A & & & & & & & \\
\hline 299-E33-29 & RCRA & $\operatorname{LLBG}(1)$ & $S$ & & $S$ & & s & & & & & $\mathrm{Sf}$ & & $\mathrm{Sf}$ & A & & & & S4 & S4 & $\mathrm{s}$ & $\mathrm{s}$ & & \\
\hline 299-E33-29 & RCRA & SST(B) & s & & $\mathrm{s}$ & & & & Q & & & & & $\mathrm{Sf}$ & & & Q & & & & $\mathrm{s}$ & & & \\
\hline 299-E33-29 & SURV & Central & & & $\mathrm{T}$ & Tf & & & & $\mathrm{T}$ & & & $\mathrm{T}$ & & & & & & & & $\mathrm{T}$ & & & FY04 \\
\hline 299-E33-30 & RCRA & $\operatorname{LLBG}(1)$ & $\mathrm{S}$ & & $S$ & & $\mathrm{~S}$ & & & & & $\mathrm{Sf}$ & & $\mathrm{Sf}$ & A & & & & S4 & S4 & $S$ & $S$ & & \\
\hline 299-E33-30 & RCRA & SST(B) & & & & & & & $\mathrm{s}$ & & A & & & & & & $\mathrm{s}$ & & & & & & & \\
\hline 299-E33-31 & RCRA & SST(B) & Q & & Q & & Q & & Q & & Q & & & Qf & & A & Q & & A4 & A4 & Q & Q & & \\
\hline 299-E33-32 & LTMC & 200BP5 & & & A & & & & & & & & & & & & A & & & & & & & \\
\hline 299-E33-32 & RCRA & SST(B) & Q & & $Q$ & & Q & & Q & & Q & & & Qf & & A & $\mathrm{Q}$ & & A4 & A4 & Q & Q & & \\
\hline 299-E33-32 & SURV & Central & & & $\mathrm{T}$ & Tf & & & & $\mathrm{T}$ & & & $\mathrm{T}$ & & & & & & & & $\mathrm{T}$ & & & FY04 \\
\hline 299-E33-33 & RCRA & B-63 & $\mathrm{A}$ & $S$ & A & & $\mathrm{S}$ & & & & & & & Af & A & & & & S4 & S4 & & & & \\
\hline 299-E33-33 & RCRA & SST(B) & $S$ & & $\mathrm{~s}$ & & & & Q & & $\mathrm{s}$ & & & Sf & & A & Q & & A4 & A4 & $\mathrm{s}$ & $\mathrm{s}$ & & \\
\hline 299-E33-33 & SURV & Central & & & $\mathrm{T}$ & Tf & & & & $\mathrm{T}$ & & & $\mathrm{T}$ & & & & & & & & $\mathrm{T}$ & $\mathrm{T}$ & & FY04 \\
\hline 299-E33-334 & LTMC & 200BP5 & & & A & & & & & & & & & & & & A & & & & & & & \\
\hline 299-E33-334 & RCRA & SST(B) & Q & & Q & & Q & & Q & & $S$ & & & Qf & & & $\mathrm{Q}$ & & A4 & A4 & Q & $\mathrm{Q}$ & & \\
\hline 299-E33-334 & SURV & Central & & & & & & & & A & & & & & & & A & & & & & A & & A:Puis \\
\hline 299-E33-335 & RCRA & SST(B) & Q & & Q & & Q & & Q & & S & & & Qf & & & $\mathrm{Q}$ & & A4 & A4 & Q & $\mathrm{Q}$ & & \\
\hline 299-E33-335 & SURV & Central & & & & & & & & A & & & & & & & A & & & & & & & A:Puis, Uiso \\
\hline 299-E33-34 & LTMC & 200BP5 & & & & & & & A & & A & & & & & & A & & & & & & & \\
\hline 299-E33-34 & RCRA & LLBG(1) & $S$ & & $S$ & & $\mathrm{~S}$ & & & & & Sf & & $\mathrm{Sf}$ & A & & & & S4 & S4 & $S$ & $S$ & & \\
\hline 299-E33-34 & RCRA & SST(B) & $S$ & & $S$ & & Q & & Q & & Q & & & Qf & & & Q & & & & $S$ & A & & \\
\hline 299-E33-34 & SURV & Central & & & $\mathrm{T}$ & Tf & & & $\mathrm{T}$ & $\mathrm{T}$ & & & $\mathrm{T}$ & & & & $\mathrm{T}$ & & & & $T$ & & & FY04 \\
\hline 299-E33-35 & LTMC & 200BP5 & & & & & & & & & & & & & & & A & & & & & & & \\
\hline 299-E33-35 & RCRA & LLBG(1) & s & & $S$ & & S & & & & & $\mathrm{Sf}$ & & $\mathrm{Sf}$ & A & & & & S4 & S4 & $S$ & $S$ & & \\
\hline
\end{tabular}




\begin{tabular}{|c|c|c|c|c|c|c|c|c|c|c|c|c|c|c|c|c|c|c|c|c|c|c|c|c|}
\hline WELL & PROG & PROJ & 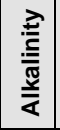 & $\frac{\pi}{\frac{0}{0}}$ & 号 & 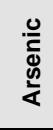 & 丞 & 屯े & $\begin{array}{l}\frac{0}{0} \\
\frac{0}{\mathrm{~T}} \\
\text { ปे }\end{array}$ & 음 & 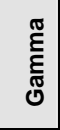 & $\begin{array}{l}0 \\
\infty \\
\infty \\
\text { ㅁ }\end{array}$ & $\underset{⿱ 亠 䒑 十}{\mathbf{I}}$ & $\underline{0}$ & $\begin{array}{l}\frac{\infty}{0} \\
\frac{\sigma}{0} \\
\frac{c}{\alpha}\end{array}$ & $\begin{array}{l}\text { के } \\
\frac{1}{\omega}\end{array}$ & 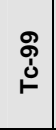 & $\stackrel{\mathscr{C}}{\circ}$ & 암 & 온 & 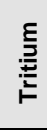 & 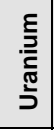 & ঠ & Other/comments \\
\hline 299-E33-35 & RCRA & SST(B) & $\mathrm{s}$ & & $S$ & & & & $Q$ & & Q & & & $\mathrm{Sf}$ & & & Q & & & & $S$ & A & & \\
\hline 299-E33-35 & SURV & Central & & $\mathrm{T}$ & $\mathrm{T}$ & Tf & $\mathrm{T}$ & & $\mathrm{T}$ & $\mathrm{T}$ & $\mathrm{T}$ & & $\mathrm{T}$ & & & & $\mathrm{T}$ & & & & $\mathrm{T}$ & $\mathrm{T}$ & & FY04 \\
\hline 299-E33-36 & RCRA & B-63 & A & $\mathrm{s}$ & A & & S & & & & & & & Af & A & & & & S4 & S4 & & & & \\
\hline 299-E33-36 & RCRA & SST(B) & s & & S & & & & S & & $S$ & & & $\mathrm{Sf}$ & & A & $\mathrm{s}$ & & A4 & A4 & $S$ & $\mathrm{~s}$ & & \\
\hline 299-E33-37 & RCRA & B-63 & A & $S$ & A & & s & & & & & & & Af & A & & & & S4 & S4 & & & & \\
\hline 299-E33-37 & SURV & Central & & & $\mathrm{T}$ & Tf & & & & $\mathrm{T}$ & & & $\mathrm{T}$ & & & & & & & & $\mathrm{T}$ & & & FY04 \\
\hline 299-E33-38 & LTMC & 200BP5 & & & A & & & & A & & A & & & & & & A & & & & & A & & \\
\hline 299-E33-38 & RCRA & SST(B) & Q & Q & $Q$ & & Q & & Q & & Q & & & Qf & & & Q & & & & Q & Q & & \\
\hline 299-E33-38 & SURV & Central & & $\mathrm{T}$ & $\mathrm{T}$ & Tf & $\mathrm{T}$ & & $\mathrm{T}$ & $\mathrm{T}$ & $\mathrm{T}$ & & $\mathrm{T}$ & & & & $\mathrm{T}$ & & & & $\mathrm{T}$ & $\mathrm{T}$ & & FY04 \\
\hline 299-E33-39 & RCRA & SST(B) & Q & & Q & & & & Q & & Q & & & Qf & & A & Q & & A4 & A4 & Q & Q & & \\
\hline 299-E33-39 & SURV & Central & & & A & Af & & & A & A & & & A & & & & A & & & & A & A & & \\
\hline 299-E33-41 & LTMC & 200BP5 & & & & & & & & & & & & & & & A & & & & & & & \\
\hline 299-E33-41 & RCRA & SST(B) & Q & $\mathrm{Q}$ & $\mathrm{Q}$ & & & & Q & & Q & & & Qf & & A & $Q$ & & $\mathrm{~A} 4$ & A4 & Q & $\mathrm{Q}$ & & \\
\hline 299-E33-41 & SURV & Central & & $\mathrm{T}$ & $\mathrm{T}$ & Tf & $\mathrm{T}$ & & $\mathrm{T}$ & $\mathrm{T}$ & $\mathrm{T}$ & & $\mathrm{T}$ & & & & $\mathrm{T}$ & & & & $\mathrm{T}$ & $\mathrm{T}$ & & FY04. T:Uiso \\
\hline 299-E33-42 & RCRA & SST(B) & Q & & $Q$ & & $Q$ & & Q & & Q & & & Qf & & A & Q & & A4 & A4 & Q & Q & & \\
\hline 299-E33-43 & RCRA & SST(B) & Q & & Q & & Q & & $\mathrm{Q}$ & & $S$ & & & Qf & & A & Q & & A4 & A4 & $Q$ & $Q$ & & \\
\hline 299-E33-44 & RCRA & SST(B) & Q & Q & $Q$ & & Q & & Q & & Q & & & Qf & & A & Q & & A4 & A4 & Q & Q & & \\
\hline 299-E33-7 & LTMC & 200BP5 & & & A & & & & A & & A & & & & & & A & & & & & & & \\
\hline 299-E33-7 & RCRA & SST(B) & Q & & $Q$ & & Q & & Q & & Q & & & Qf & & & Q & & & & $\mathrm{Q}$ & Q & & \\
\hline 299-E33-7 & SURV & Central & & A & A & & A & & $\mathrm{A}$ & A & A & & A & & & & A & & & & A & A & & \\
\hline 299-E33-9 & LTMC & 200BP5 & & & A & & & & A & & A & & & & & & A & & & & & A & & \\
\hline 299-E33-9 & RCRA & SST(B) & Q & $\mathrm{Q}$ & $\mathrm{Q}$ & & $\mathrm{Q}$ & & Q & & Q & & & Qf & & $S$ & Q & & A4 & A4 & Q & $\mathrm{Q}$ & & \\
\hline 299-E34-10 & RCRA & B-63 & A & $S$ & A & & $S$ & & & & & & & Af & A & & & & S4 & S4 & & & & \\
\hline 299-E34-10 & RCRA & LLBG(2) & $\mathrm{S}$ & $S$ & $S$ & & $S$ & & & & & $\mathrm{Sf}$ & & $\mathrm{Sf}$ & A & & & & S4 & S4 & $S$ & & & S:PCB \\
\hline 299-E34-11 & RCRA & LLBG(2) & $\mathrm{S}$ & $S$ & $S$ & & $S$ & & & & & $\mathrm{Sf}$ & & $\mathrm{Sf}$ & A & & & & S4 & S4 & $S$ & & & S:PCB \\
\hline 299-E34-11 & SURV & Central & & $\mathrm{T}$ & $\mathrm{T}$ & Tf & $\mathrm{T}$ & & & $\mathrm{T}$ & & & $\mathrm{T}$ & & & & & & & & $\mathrm{T}$ & & & FY04 \\
\hline 299-E34-12 & RCRA & LLBG(2) & $S$ & $S$ & $\mathrm{~s}$ & & $S$ & & & & & $\mathrm{Sf}$ & & $\mathrm{Sf}$ & $\mathrm{A}$ & & & & S4 & S4 & $S$ & & & S:PCB \\
\hline 299-E34-2 & RCRA & LLBG(2) & $\mathrm{s}$ & $S$ & $S$ & & $S$ & & & & & $\mathrm{Sf}$ & & $\mathrm{Sf}$ & A & & & & S4 & S4 & $S$ & & & S:PCB \\
\hline 299-E34-2 & SURV & Central & & & A & Af & & & & A & & & A & & & & & & & & A & & & \\
\hline 299-E34-3 & RCRA & LLBG(2) & $S$ & $S$ & $S$ & & $S$ & & & & & $\mathrm{Sf}$ & & $\mathrm{Sf}$ & A & & & & S4 & S4 & $S$ & & & S:PCB \\
\hline 299-E34-5 & RCRA & LLBG(2) & $S$ & $S$ & $S$ & & $S$ & & & & & $\mathrm{Sf}$ & & $\mathrm{Sf}$ & A & & & & s & s & $S$ & & & S:PCB \\
\hline
\end{tabular}




\begin{tabular}{|c|c|c|c|c|c|c|c|c|c|c|c|c|c|c|c|c|c|c|c|c|c|c|c|c|}
\hline WELL & PROG & PROJ & 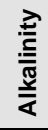 & $\frac{\frac{\pi}{2}}{\frac{0}{\alpha}}$ & $\frac{\mathscr{0}}{\frac{0}{\pi}}$ & $\begin{array}{l}\stackrel{0}{\bar{乛}} \\
\frac{\Phi}{\alpha} \\
\frac{\omega}{\alpha}\end{array}$ & Фూ & 屯े & 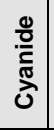 & 음 & 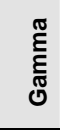 & $\begin{array}{l}\stackrel{0}{\alpha} \\
\infty \\
\text { ㅁ }\end{array}$ & $\underset{⿱ 亠 䒑 十}{\mathbf{I}}$ & $\stackrel{0}{0}$ & $\begin{array}{l}\frac{\infty}{0} \\
\frac{0}{0} \\
\frac{\pi}{\alpha}\end{array}$ & $\begin{array}{l}\text { के } \\
\frac{1}{\omega}\end{array}$ & $\begin{array}{l}\stackrel{8}{i} \\
\text { i }\end{array}$ & $\stackrel{\mathscr{c}}{\circ}$ & 암 & 옴 & 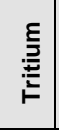 & 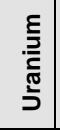 & $\stackrel{\nwarrow}{\supset}$ & Other/comments \\
\hline 299-E34-5 & SURV & Central & & & T & & & & & $\mathrm{T}$ & & & $\mathrm{T}$ & & & & & & & & T & & & FY04 \\
\hline 299-E34-7 & RCRA & LLBG(2) & S & $S$ & $S$ & & $S$ & & & & & $\mathrm{Sf}$ & & $\mathrm{Sf}$ & A & & & & S4 & S4 & $S$ & & & S:PCB \\
\hline 299-E34-7 & SURV & Central & & A & A & & A & & & A & & & & & & & & & & & A & & & \\
\hline 299-E34-8 & RCRA & B-63 & A & $S$ & A & & $\mathrm{s}$ & & & & & & & Af & A & & & & S4 & S4 & & & & \\
\hline 299-E34-9 & RCRA & LLBG(2) & $S$ & $S$ & $S$ & & $S$ & & & & & $\mathrm{Sf}$ & & $\mathrm{Sf}$ & A & & & & S4 & S4 & $S$ & & & S:PCB \\
\hline 299-E34-9 & SURV & Central & & $\mathrm{T}$ & $\mathrm{T}$ & Tf & $\mathrm{T}$ & & & $\mathrm{T}$ & & & $\mathrm{T}$ & & & & & & & & $\mathrm{T}$ & & & FY04 \\
\hline 299-W10-1 & RCRA & SST(T) & Q & $Q$ & $Q$ & & $S$ & & & & Q & & & Qf & & & Q & & & & $Q$ & & & \\
\hline 299-W10-1 & SURV & West & & A & A & & & & & A & A & & A & Af & & & A & & & & A & & A & \\
\hline 299-W10-13 & RCRA & LLBG(3) & $\mathrm{s}$ & $\mathrm{s}$ & $\mathrm{s}$ & & $S$ & & & & & Sf & & $\mathrm{Sf}$ & A & & & & S4 & S4 & $S$ & & $\mathrm{~s}$ & \\
\hline 299-W10-13 & SURV & West & & & A & & & & & A & & & & & & & & & & & A & & A & \\
\hline 299-W10-14 & RCRA & LLBG(3) & $\mathrm{S}$ & $S$ & $S$ & & $s$ & & & & & $\mathrm{Sf}$ & & $\mathrm{Sf}$ & $\mathrm{A}$ & & & & $\mathrm{S}$ & $\mathrm{s}$ & $S$ & & $\mathrm{~s}$ & Deep unconfined. \\
\hline 299-W10-14 & SURV & West & & A & A & & A & & & A & & & & & & & & & & & A & & $\mathrm{A}$ & Deep unconfined. \\
\hline 299-W10-17 & RCRA & SST(TX/TY) & Q & $Q$ & Q & & $S$ & & & & $\mathrm{~S}$ & & & Qf & & & Q & & & & $Q$ & & & \\
\hline 299-W10-19 & RCRA & LLBG(3) & $\mathrm{s}$ & $\mathrm{s}$ & $\mathrm{s}$ & & $\mathrm{s}$ & & & & & $\mathrm{Sf}$ & & $\mathrm{Sf}$ & A & & & & S4 & S4 & $\mathrm{s}$ & & $\mathrm{S}$ & \\
\hline 299-W10-20 & RCRA & LLBG(3) & $\mathrm{s}$ & $S$ & $S$ & & $S$ & & & & & $\mathrm{Sf}$ & & $\mathrm{Sf}$ & A & & & & S4 & S4 & $S$ & & $S$ & \\
\hline 299-W10-20 & SURV & West & & A & A & & A & & & A & & & & & & & & & & & A & & A & \\
\hline 299-W10-21 & RCRA & LLBG(3) & $S$ & $S$ & $S$ & & $S$ & & & & & $\mathrm{Sf}$ & & $\mathrm{Sf}$ & A & & & & S4 & S4 & $S$ & & $S$ & \\
\hline 299-W10-21 & SURV & West & & A & A & & & & & A & & & & & & & & & & & A & & A & \\
\hline 299-W10-22 & RCRA & SST(T) & $\mathrm{S}$ & $S$ & $S$ & & $S$ & & & & $S$ & & & $\mathrm{Sf}$ & & & $S$ & & & & $S$ & & & \\
\hline 299-W10-22 & SURV & West & & A & A & & & & & A & & & A & Af & & & A & & & & A & & A & \\
\hline 299-W10-23 & RCRA & SST(T) & Q & $Q$ & $Q$ & & $S$ & & & & Q & & & Qf & & A & $Q$ & & & & $Q$ & & A & \\
\hline 299-W10-24 & RCRA & SST(T) & Q & $Q$ & $Q$ & & $S$ & & & & Q & & & Qf & & A & $Q$ & & & & $Q$ & & & \\
\hline 299-W10-26 & RCRA & SST(TX/TY) & $Q$ & $\mathrm{Q}$ & $Q$ & & $s$ & & & & $Q$ & & & Qf & & A & $Q$ & & & & $Q$ & & & \\
\hline 299-W10-27 & RCRA & SST(TX/TY) & Q & $Q$ & Q & & $S$ & & & & Q & & & Qf & & A & $Q$ & & & & $Q$ & & & \\
\hline 299-W10-4 & RCRA & SST(T) & $Q$ & $Q$ & $Q$ & & $S$ & & & & $Q$ & & & Qf & & & $\mathrm{Q}$ & & & & $Q$ & & A & \\
\hline 299-W10-4 & SURV & West & & A & A & & & & & A & & & A & Af & & & A & & & & A & & A & \\
\hline 299-W10-5 & SURV & West & & A & A & & & & & A & & & A & Af & & & A & & & & A & & A & \\
\hline 299-W10-8 & RCRA & SST(T) & $S$ & $S$ & $S$ & & $S$ & & & & $S$ & & & $\mathrm{Sf}$ & & & $\mathrm{s}$ & & & & $S$ & & & \\
\hline 299-W11-10 & SURV & West & & & A & & & & & A & & & $\mathrm{A}$ & & & & A & & & & A & & A & \\
\hline 299-W11-12 & RCRA & SST(T) & $\mathrm{Q}$ & $\mathrm{Q}$ & Q & & $S$ & & & & Q & & & Qf & & & $\mathrm{Q}$ & & & & $Q$ & & & \\
\hline 299-W11-13 & SURV & West & $\mathrm{A}$ & & A & & & & & A & & & A & Af & & & A & & & & A & A & A & \\
\hline
\end{tabular}




\begin{tabular}{|c|c|c|c|c|c|c|c|c|c|c|c|c|c|c|c|c|c|c|c|c|c|c|c|c|}
\hline WELL & PROG & PROJ & 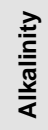 & $\frac{\frac{\pi}{0}}{\frac{0}{\alpha}}$ & $\frac{\mathscr{0}}{\frac{0}{c}}$ & 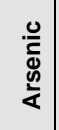 & 胥 & 屯ัँ & $\begin{array}{l}\frac{0}{\circ} \\
\frac{0}{\mathrm{~T}} \\
\text { ปे }\end{array}$ & ㅇ & 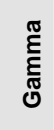 & $\begin{array}{l}0 \\
0 \\
\infty \\
ㅁ \\
\text { I }\end{array}$ & $\stackrel{\text { ని }}{\underline{I}}$ & $\underline{0}$ & $\begin{array}{l}\frac{0}{0} \\
\frac{0}{0} \\
\frac{5}{\alpha}\end{array}$ & $\begin{array}{l}\text { के } \\
\frac{1}{\omega}\end{array}$ & 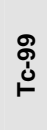 & $\stackrel{\text { 足 }}{口}$ & O & 음 & 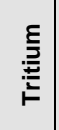 & 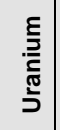 & § & Other/comments \\
\hline 299-W11-14 & SURV & West & & & & & & & & A & A & & A & & & & A & & & & A & A & A & \\
\hline 299-W11-18 & SURV & West & & A & A & & A & & & $A$ & A & & A & & & & & & & & & A & A & \\
\hline 299-W11-24 & RCRA & SST(T) & $Q$ & $Q$ & $Q$ & & S & & & & $Q$ & & & Qf & & & $Q$ & & & & $Q$ & & & \\
\hline 299-W11-3 & SURV & West & & & & & & & & A & & & A & & & & A & & & & $A$ & $A$ & $A$ & \\
\hline 299-W11-37 & SURV & West & & & $\mathrm{A}$ & & & & & A & & & A & Af & & & $\mathrm{A}$ & & & & A & A & A & \\
\hline 299-W11-39 & RCRA & SST(T) & $Q$ & $Q$ & $Q$ & & $S$ & & & & $Q$ & & & Qf & & & $Q$ & & & & $Q$ & & & \\
\hline 299-W11-40 & RCRA & $\mathrm{SST}(\mathrm{T})$ & $Q$ & $Q$ & $Q$ & & $S$ & & & & $Q$ & & & Qf & & & $Q$ & & & & $Q$ & & & \\
\hline 299-W11-41 & RCRA & SST $(T)$ & $Q$ & $\mathrm{Q}$ & $Q$ & & $S$ & & & & $Q$ & & & Qf & & & $Q$ & & & & $Q$ & & & \\
\hline 299-W11-42 & RCRA & $\mathrm{SST}(\mathrm{T})$ & Q & $Q$ & $\mathrm{Q}$ & & $S$ & & & & Q & & & Qf & & & $Q$ & & & & Q & & & \\
\hline 299-W11-42 & SURV & West & & $A$ & A & & $A$ & & & A & & & A & Af & & & A & & & & A & & A & \\
\hline 299-W11-6 & SURV & West & & & A & & & & & $A$ & & & A & & & & A & & & & A & & A & \\
\hline 299-W11-7 & RCRA & SST(T) & $S$ & $S$ & $\mathrm{~s}$ & & $S$ & & & & $S$ & & & $\mathrm{Sf}$ & & & $\mathrm{s}$ & & & & $\mathrm{s}$ & & & \\
\hline 299-W11-7 & SURV & West & & & A & & & & & A & & & A & & & & A & & & & A & A & A & \\
\hline 299-W12-1 & SURV & West & & & $\mathrm{A}$ & & & & & A & & & A & Af & & & A & & & & $A$ & A & A & \\
\hline 299-W14-13 & RCRA & SST(TX/TY) & $Q$ & $Q$ & $Q$ & & $S$ & & & & $Q$ & & $Q$ & Qf & & $A$ & $Q$ & & & & $Q$ & & & \\
\hline 299-W14-14 & RCRA & SST(TX/TY) & Q & $Q$ & $Q$ & & $S$ & & & & $Q$ & & & Qf & & & $Q$ & & & & Q & & & \\
\hline 299-W14-14 & SURV & West & & $\mathrm{A}$ & $\mathrm{A}$ & & & & & A & A & & A & Af & & & A & & & & A & & A & \\
\hline 299-W14-15 & RCRA & SST(TX/TY) & $Q$ & $Q$ & $Q$ & & $S$ & & & & $Q$ & & $Q$ & Qf & & & $Q$ & & & & $Q$ & & & \\
\hline 299-W14-16 & RCRA & SST(TX/TY) & $Q$ & $Q$ & $Q$ & & $\mathrm{~s}$ & & & & $Q$ & & & Qf & & & $Q$ & & & & $Q$ & & & \\
\hline 299-W14-17 & RCRA & SST(TX/TY) & $Q$ & $Q$ & $Q$ & & S & & & & $Q$ & & & Qf & & & $Q$ & & & & $Q$ & & & \\
\hline 299-W14-5 & RCRA & SST(TX/TY) & $Q$ & $Q$ & $Q$ & & $S$ & & & & $Q$ & & & Qf & & & $Q$ & & & & $Q$ & & & \\
\hline 299-W14-6 & RCRA & SST(TX/TY) & $Q$ & $Q$ & $Q$ & & $S$ & & & & $Q$ & & & Qf & & & $Q$ & & & & $Q$ & & & \\
\hline 299-W14-6 & SURV & West & & $A$ & A & & & & & A & A & & A & Af & & & $A$ & & & & $A$ & & A & \\
\hline 299-W14-9 & CERC & 200ZP1 & & & & & & & & & & & & & & & & & & & & & $Q$ & \\
\hline 299-W14-9 & SURV & West & & $A$ & A & & $A$ & & & $A$ & & & & & & & & & & & $A$ & & $A$ & Bottom unconfined. \\
\hline 299-W15-1 & CERC & 200ZP1 & & & & & & & & & & & & & & & & & & & & & $Q$ & \\
\hline 299-W15-11 & CERC & 200ZP1 & & & & & & & & & & & & & & & & & & & & & $Q$ & \\
\hline 299-W15-11 & SURV & West & & A & A & & $A$ & & & A & & & & & & & & & & & & & & \\
\hline 299-W15-15 & CERC & 200ZP1 & & & & & & & & & & & & & & & & & & & & & Q & \\
\hline 299-W15-15 & RCRA & LLBG(4) & $S$ & $\mathrm{~S}$ & $S$ & & $\mathrm{~s}$ & & & & & $\mathrm{Sf}$ & $S$ & $\mathrm{Sf}$ & A & & $S$ & & S4 & S4 & $S$ & & $\mathrm{~S}$ & \\
\hline 299-W15-15 & SURV & West & & & $A$ & & & & & A & & & & & & & & & & & & & A & \\
\hline
\end{tabular}




\begin{tabular}{|c|c|c|c|c|c|c|c|c|c|c|c|c|c|c|c|c|c|c|c|c|c|c|c|c|}
\hline WELL & PROG & PROJ & 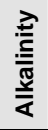 & $\frac{\frac{\pi}{2}}{\frac{0}{2}}$ & $\frac{0}{\frac{0}{c}}$ & 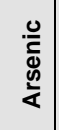 & 䋨 & 屯े & $\begin{array}{l}\frac{0}{0} \\
\stackrel{0}{\frac{\pi}{5}} \\
\text { తิ }\end{array}$ & 옹 & 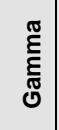 & $\begin{array}{l}\text { 오 } \\
\infty \\
\text { 옹 }\end{array}$ & $\underset{\text { 오 }}{1}$ & $\underline{0}$ & $\begin{array}{l}\frac{n}{0} \\
\frac{0}{0} \\
\frac{\pi}{\alpha}\end{array}$ & $\begin{array}{l}\frac{8}{9} \\
\frac{1}{\omega}\end{array}$ & $\begin{array}{l}\stackrel{8}{8} \\
\text { பे }\end{array}$ & $\stackrel{\mathscr{O}}{\circ}$ & 옴 & ํㅗㅁ & 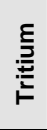 & 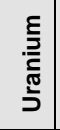 & $\stackrel{\nwarrow}{\text { \} }} &{\text { Other/comments }} \\
{\hline \text { 299-W15-16 }} &{\text { CERC }} &{\text { 200ZP1 }} &{ } &{ } &{ } &{ } &{ } &{ } &{ } &{ } &{ } &{ } &{ } &{ } &{ } &{ } &{ } &{ } &{ } &{ } &{ } &{ } &{\mathrm{s}} &{ } \\
{\hline \text { 299-W15-16 }} &{\text { RCRA }} &{\text { LLBG(4) }} &{\mathrm{s}} &{\mathrm{s}} &{\mathrm{s}} &{ } &{\mathrm{s}} &{ } &{ } &{ } &{ } &{\text { Sf }} &{\mathrm{s}} &{\mathrm{Sf}} &{\text { A }} &{ } &{\mathrm{s}} &{ } &{\text { S4 }} &{\text { S4 }} &{\mathrm{s}} &{ } &{\mathrm{s}} &{ } \\
{\hline \text { 299-W15-16 }} &{\text { SURV }} &{\text { West }} &{ } &{ } &{\text { A }} &{ } &{ } &{ } &{ } &{A} &{ } &{ } &{ } &{ } &{ } &{ } &{ } &{ } &{ } &{ } &{ } &{ } &{\text { A }} &{ } \\
{\hline \text { 299-W15-17 }} &{\text { RCRA }} &{\text { LLBG(4) }} &{S} &{\text { S }} &{S} &{ } &{S} &{ } &{ } &{ } &{ } &{\mathrm{Sf}} &{ } &{\mathrm{Sf}} &{\text { A }} &{ } &{ } &{ } &{\mathrm{s}} &{\mathrm{s}} &{\mathrm{s}} &{ } &{S} &{\text { Deep unconfined (b). }} \\
{\hline \text { 299-W15-17 }} &{\text { SURV }} &{\text { West }} &{ } &{\text { A }} &{\text { A }} &{ } &{\text { A }} &{ } &{ } &{\text { A }} &{ } &{ } &{ } &{ } &{ } &{ } &{ } &{ } &{ } &{ } &{\text { A }} &{ } &{\text { A }} &{\text { Deep unconfined (b). }} \\
{\hline \text { 299-W15-2 }} &{\text { SURV }} &{\text { West }} &{\text { A }} &{\mathrm{A}} &{\mathrm{A}} &{ } &{\text { A }} &{ } &{ } &{\text { A }} &{ } &{ } &{\text { A }} &{\text { Af }} &{ } &{ } &{\text { A }} &{ } &{ } &{ } &{\text { A }} &{ } &{\text { A }} &{ } \\
{\hline \text { 299-W15-30 }} &{\text { CERC }} &{\text { 200ZP1 }} &{ } &{ } &{ } &{ } &{ } &{ } &{ } &{ } &{ } &{ } &{ } &{ } &{ } &{ } &{ } &{ } &{ } &{ } &{ } &{ } &{\mathrm{s}} &{ } \\
{\hline \text { 299-W15-31A }} &{\text { CERC }} &{\text { 200ZP1 }} &{ } &{ } &{ } &{ } &{ } &{ } &{ } &{ } &{ } &{ } &{ } &{ } &{ } &{ } &{ } &{ } &{ } &{ } &{ } &{ } &{\text { Q }} &{ } \\
{\hline \text { 299-W15-32 }} &{\text { CERC }} &{\text { 200ZP1 }} &{ } &{ } &{ } &{ } &{ } &{ } &{ } &{ } &{ } &{ } &{\text { A }} &{ } &{ } &{ } &{\text { A }} &{ } &{ } &{ } &{\text { A }} &{ } &{ } &{\text { Extraction well. }} \\
{\hline \text { 299-W15-32 }} &{\text { ERC }} &{\text { 200ZP1 PT }} &{ } &{ } &{ } &{ } &{ } &{ } &{ } &{ } &{ } &{ } &{ } &{ } &{ } &{ } &{ } &{ } &{ } &{ } &{ } &{ } &{\text { BW }} &{\text { Extraction well. }} \\
{\hline \text { 299-W15-32 }} &{\text { SURV }} &{\text { West }} &{ } &{ } &{\text { A }} &{ } &{ } &{ } &{ } &{\text { A }} &{\text { A }} &{ } &{ } &{\text { Af }} &{ } &{ } &{\text { A }} &{ } &{ } &{ } &{\text { A }} &{ } &{\mathrm{A}} &{\text { Extraction well. A:Am, Np, Puis }} \\
{\hline \text { 299-W15-33 }} &{\text { CERC }} &{\text { 200ZP1 }} &{ } &{ } &{ } &{ } &{ } &{ } &{ } &{ } &{ } &{ } &{\text { A }} &{ } &{ } &{ } &{\mathrm{A}} &{ } &{ } &{ } &{\mathrm{A}} &{ } &{ } &{\text { Extraction well. }} \\
{\hline \text { 299-W15-33 }} &{\text { ERC }} &{\text { 200ZP1 PT }} &{ } &{ } &{ } &{ } &{ } &{ } &{ } &{ } &{ } &{ } &{ } &{ } &{ } &{ } &{ } &{ } &{ } &{ } &{ } &{ } &{\text { BW }} &{\text { Extraction well. }} \\
{\hline \text { 299-W15-34 }} &{\text { CERC }} &{\text { 200ZP1 }} &{ } &{ } &{ } &{ } &{ } &{ } &{ } &{ } &{ } &{ } &{\text { A }} &{ } &{ } &{ } &{\text { A }} &{ } &{ } &{ } &{\text { A }} &{ } &{ } &{\text { Extraction well. }} \\
{\hline \text { 299-W15-34 }} &{\text { ERC }} &{\text { 200ZP1 PT }} &{ } &{ } &{ } &{ } &{ } &{ } &{ } &{ } &{ } &{ } &{ } &{ } &{ } &{ } &{ } &{ } &{ } &{ } &{ } &{ } &{\text { BW }} &{\text { Extraction well. }} \\
{\hline \text { 299-W15-34 }} &{\text { SURV }} &{\text { West }} &{ } &{ } &{\text { A }} &{ } &{ } &{ } &{ } &{\text { A }} &{ } &{ } &{ } &{ } &{ } &{ } &{\text { A }} &{ } &{ } &{ } &{\text { A }} &{ } &{\text { A }} &{\text { Extraction well. }} \\
{\hline \text { 299-W15-35 }} &{\text { CERC }} &{\text { 200ZP1 }} &{ } &{ } &{ } &{ } &{ } &{ } &{ } &{ } &{ } &{ } &{\text { A }} &{ } &{ } &{ } &{\text { A }} &{ } &{ } &{ } &{\text { A }} &{ } &{ } &{\text { Extraction well. }} \\
{\hline \text { 299-W15-35 }} &{\text { ERC }} &{\text { 200ZP1 PT }} &{ } &{ } &{ } &{ } &{ } &{ } &{ } &{ } &{ } &{ } &{ } &{ } &{ } &{ } &{ } &{ } &{ } &{ } &{ } &{ } &{\text { BW }} &{\text { Extraction well. }} \\
{\hline \text { 299-W15-36 }} &{\text { CERC }} &{\text { 200ZP1 }} &{ } &{ } &{ } &{ } &{ } &{ } &{ } &{ } &{ } &{ } &{\text { A }} &{ } &{ } &{ } &{\text { A }} &{ } &{ } &{ } &{\text { A }} &{ } &{ } &{\text { Extraction well. }} \\
{\hline \text { 299-W15-36 }} &{\text { ERC }} &{\text { 200ZP1 PT }} &{ } &{ } &{ } &{ } &{ } &{ } &{ } &{ } &{ } &{ } &{ } &{ } &{ } &{ } &{ } &{ } &{ } &{ } &{ } &{ } &{\text { BW }} &{\text { Extraction well. }} \\
{\hline \text { 299-W15-36 }} &{\text { SURV }} &{\text { West }} &{ } &{ } &{\text { A }} &{ } &{ } &{ } &{ } &{\text { A }} &{ } &{ } &{ } &{ } &{ } &{ } &{\text { A }} &{ } &{ } &{ } &{ } &{ } &{\text { A }} &{\text { Extraction well. }} \\
{\hline \text { 299-W15-37 }} &{\text { CERC }} &{\text { 200ZP1 }} &{ } &{ } &{ } &{ } &{ } &{ } &{ } &{ } &{ } &{ } &{ } &{ } &{ } &{ } &{ } &{ } &{ } &{ } &{ } &{ } &{\text { Q }} &{\text { Former extraction well. }} \\
{\hline \text { 299-W15-37 }} &{\text { ERC }} &{\text { 200ZP1 PT }} &{ } &{ } &{ } &{ } &{ } &{ } &{ } &{ } &{ } &{ } &{ } &{ } &{ } &{ } &{ } &{ } &{ } &{ } &{ } &{ } &{\text { BW }} &{\text { Former extraction well. }} \\
{\hline \text { 299-W15-37 }} &{\text { SURV }} &{\text { West }} &{ } &{ } &{\mathrm{A}} &{ } &{ } &{ } &{ } &{\text { A }} &{ } &{ } &{ } &{ } &{ } &{ } &{\text { A }} &{ } &{ } &{ } &{ } &{ } &{\text { A }} &{\text { Former extraction well. }} \\
{\hline \text { 299-W15-38 }} &{\text { CERC }} &{\text { 200ZP1 }} &{ } &{ } &{ } &{ } &{ } &{ } &{ } &{ } &{ } &{ } &{ } &{ } &{ } &{ } &{ } &{ } &{ } &{ } &{ } &{ } &{\mathrm{Q}} &{ } \\
{\hline \text { 299-W15-39 }} &{\text { CERC }} &{\text { 200ZP1 }} &{ } &{ } &{ } &{ } &{ } &{ } &{ } &{ } &{ } &{ } &{ } &{ } &{ } &{ } &{ } &{ } &{ } &{ } &{ } &{ } &{Q} &{ } \\
{\hline \text { 299-W15-40 }} &{\text { RCRA }} &{\text { SST(TX/TY) }} &{\text { Q }} &{\text { Q }} &{\text { Q }} &{ } &{S} &{ } &{ } &{ } &{\text { Q }} &{ } &{ } &{\text { Qf }} &{ } &{ } &{\text { Q }} &{ } &{ } &{ } &{\text { Q }} &{ } &{ } &{ } \\
{\hline \text { 299-W15-40 }} &{\text { SURV }} &{\text { West }} &{ } &{\text { A }} &{\text { A }} &{ } &{\text { A }} &{ } &{ } &{\text { A }} &{ } &{ } &{\text { A }} &{ } &{ } &{ } &{\text { A }} &{ } &{ } &{ } &{\text { A }} &{ } &{\text { A }} &{ } \\
{\hline \text { 299-W15-41 }} &{\text { RCRA }} &{\text { SST(TX/TY) }} &{\text { Q }} &{Q} &{Q} &{ } &{S} &{ } &{ } &{ } &{\text { Q }} &{ } &{ } &{\text { Qf }} &{ } &{\text { A }} &{Q} &{ } &{ } &{ } &{Q} &{ } &{ } &{ } \\
{\hline \text { 299-W15-41 }} &{\text { SURV }} &{\text { West }} &{ } &{\text { A }} &{\text { A }} &{ } &{\text { A }} &{ } &{ } &{\text { A }} &{ } &{ } &{\text { A }} &{ } &{ } &{ } &{\text { A }} &{ } &{ } &{ } &{\text { A }} &{ } &{\text { A }} &{ } \\
{\hline \text { 299-W15-7 }} &{\text { CERC }} &{\text { 200ZP1 }} &{ } &{ } &{ } &{ } &{ } &{ } &{ } &{ } &{ } &{ } &{ } &{ } &{ } &{ } &{ } &{ } &{ } &{ } &{ } &{ } &{\text { Q }} &{ } \\
$\hline
\end{tabular}




\begin{tabular}{|c|c|c|c|c|c|c|c|c|c|c|c|c|c|c|c|c|c|c|c|c|c|c|c|c|}
\hline WELL & PROG & PROJ & $\begin{array}{l}\stackrel{2}{\vec{J}} \\
\text { 可 } \\
\text { 妾 }\end{array}$ & $\frac{\pi}{\frac{0}{0}}$ & 号 & 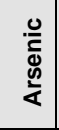 & $\begin{array}{l}\text { 总 } \\
\text { D. }\end{array}$ & 屯ेँ & $\begin{array}{l}\frac{0}{0} \\
\frac{0}{\mathrm{C}} \\
\text { ปे }\end{array}$ & 음 & 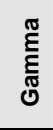 & $\begin{array}{l}0 \\
\infty \\
\infty \\
\text { ㅁ }\end{array}$ & 옴 & $\underline{0}$ & $\begin{array}{l}\frac{\infty}{0} \\
\frac{\bar{\sigma}}{0} \\
\frac{c}{\alpha}\end{array}$ & $\begin{array}{l}\text { के } \\
\frac{1}{\omega}\end{array}$ & $\begin{array}{l}\stackrel{8}{8} \\
\text { ப் }\end{array}$ & 足 & 옴 & 음 & 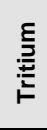 & 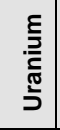 & §̊ & Other/comments \\
\hline 299-W15-763 & RCRA & SST(TX/TY) & Q & $Q$ & $Q$ & & $\mathrm{~s}$ & & & & Q & & & Qf & & A & $Q$ & & & & Q & & & \\
\hline 299-W15-764 & CERC & 200ZP1 & & & & & & & & & & & & & & & & & & & & & Q & \\
\hline 299-W18-1 & CERC & 200ZP1 & & & & & & & & & & & & & & & & & & & & & Q & \\
\hline 299-W18-1 & SURV & West & & A & A & & A & & & A & & & & Af & & & & & & & & & A & A:Puis \\
\hline 299-W18-15 & SURV & West & & & & & A & & & A & & & & & & & & & & & & A & A & \\
\hline 299-W18-21 & CERC & 200ZP1 & & & & & & & & & & & & & & & & & & & & & $\mathrm{S}$ & \\
\hline 299-W18-21 & RCRA & LLBG(4) & $\mathrm{s}$ & $\mathrm{s}$ & $\mathrm{s}$ & & $\mathrm{s}$ & & & & & $\mathrm{Sf}$ & & $\mathrm{Sf}$ & A & & & & S4 & S4 & $\mathrm{s}$ & & $\mathrm{s}$ & \\
\hline 299-W18-21 & SURV & West & & & & & & & & A & & & & & & & & & & & & A & A & \\
\hline 299-W18-22 & RCRA & LLBG(4) & $\mathrm{s}$ & S & $\mathrm{s}$ & & $\mathrm{s}$ & & & & & $\mathrm{Sf}$ & & Sf & A & & & & $\mathrm{s}$ & $\mathrm{s}$ & $\mathrm{s}$ & & $S$ & Deep unconfined (b). \\
\hline 299-W18-22 & SURV & West & & & A & & A & & & A & & & & & & & & & & & A & A & A & Deep unconfined (b). \\
\hline 299-W18-23 & RCRA & LLBG(4) & $S$ & $S$ & $\mathrm{~S}$ & & $\mathrm{~s}$ & & & & & $\mathrm{Sf}$ & $\mathrm{s}$ & Sf & A & & $\mathrm{s}$ & & S4 & S4 & $\mathrm{s}$ & & $\mathrm{S}$ & \\
\hline 299-W18-23 & SURV & West & & & A & & & & & A & & & & & & & & & & & & & A & \\
\hline 299-W18-24 & CERC & 200ZP1 & & & & & & & & & & & & & & & & & & & & & $\mathrm{s}$ & \\
\hline 299-W18-24 & RCRA & $\operatorname{LLBG}(4)$ & $\mathrm{s}$ & $\mathrm{s}$ & $\mathrm{s}$ & & $\mathrm{s}$ & & & & & $\mathrm{Sf}$ & & $\mathrm{Sf}$ & A & & & & S4 & S4 & $\mathrm{s}$ & & $\mathrm{s}$ & \\
\hline 299-W18-24 & SURV & West & & & A & & & & & A & & & & & & & A & & & & & & A & \\
\hline 299-W18-27 & CERC & 200ZP1 & & & & & & & & & & & & & & & & & & & & & Q & \\
\hline 299-W18-30 & CERC & 200ZP1 & & & & & & & & & & & & & & & & & & & & & Q & \\
\hline 299-W18-30 & RCRA & SST $(U)$ & Q & A & Q & & & & & & A & & A & Qf & & & Q & & & & A & & A & \\
\hline 299-W18-31 & RCRA & SST(U) & Q & A & Q & & & & & & A & & A & Qf & & & Q & & & & A & & A & \\
\hline 299-W18-33 & SURV & West & & & $\mathrm{A}$ & & A & & & A & & & & Af & & & & & & & $\mathrm{A}$ & A & A & \\
\hline 299-W18-4 & CERC & 200ZP1 & & & & & & & & & & & & & & & & & & & & & $Q$ & \\
\hline 299-W19-12 & RCRA & SST(U) & Q & A & Q & & & & & & A & & A & Qf & & & Q & & & & A & & $\mathrm{A}$ & \\
\hline 299-W19-14 & SURV & West & & & A & & & & & A & & & A & & & & A & & & & & A & A & \\
\hline 299-W19-16 & SURV & West & & & A & & & & & A & & & A & & & & A & & & & A & A & & \\
\hline 299-W19-20 & CERC & 200UP1 & & & & & & & & & & & & & & & Q & & & & & Q & Q & \\
\hline 299-W19-20 & SURV & West & & & A & & & & & A & & & A & & & & A & & & & & A & & \\
\hline 299-W19-21 & SURV & West & & A & A & & A & & & A & & & & & & & & & & & A & & A & \\
\hline 299-W19-34A & CERC & 200UP1 & & & & & & & & & & & & & & & Q & & & & & Q & Q & \\
\hline 299-W19-34B & CERC & 200UP1 & & & & & & & & & & & & & & & Q & & & & & Q & Q & Date of first sampling TBD. \\
\hline 299-W19-35 & CERC & 200UP1 & & & & & & & & & & & & & & & Q & & & & & Q & Q & \\
\hline 299-W19-35 & SURV & West & & & A & & & & & A & & & A & & & & A & & & & A & A & A & \\
\hline
\end{tabular}




\begin{tabular}{|c|c|c|c|c|c|c|c|c|c|c|c|c|c|c|c|c|c|c|c|c|c|c|c|c|}
\hline WELL & PROG & PROJ & 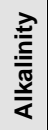 & $\frac{\frac{\pi}{2}}{\frac{2}{\alpha}}$ & $\begin{array}{l}n \\
\stackrel{n}{0} \\
\frac{0}{\pi}\end{array}$ & $\begin{array}{l}0 \\
\frac{0}{\bar{J}} \\
\frac{\omega}{<} \\
\end{array}$ & Фீ & 屯ั & $\begin{array}{l}\frac{1}{0} \\
\frac{0}{5} \\
\text { ปे }\end{array}$ & ○ & 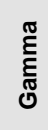 & $\begin{array}{l}0 \\
\text { Q } \\
\infty \\
\text { 오 }\end{array}$ & $\frac{\mathbb{2}}{\square}$ & $\underline{\underline{0}}$ & $\begin{array}{l}\frac{\infty}{0} \\
\frac{\Phi}{\alpha} \\
\frac{\delta}{\alpha}\end{array}$ & $\begin{array}{l}\text { के } \\
\frac{1}{\omega}\end{array}$ & $\begin{array}{l}\stackrel{8}{:} \\
\dot{0}\end{array}$ & $\stackrel{\mathscr{L}}{R}$ & O & 음 & 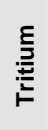 & 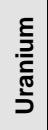 & ঠீ & Other/comments \\
\hline 299-W19-36 & CERC & 200UP1 & & & & & & & & & & & & & & & Q & & & & & Q & Q & \\
\hline 299-W19-37 & CERC & 200UP1 & & & & & & & & & & & & & & & Q & & & & & Q & Q & \\
\hline 299-W19-39 & CERC & 200UP1 & & & & & & & & & & & & & & & Q & & & & & Q & Q & Extraction well. \\
\hline 299-W19-4 & SURV & West & & & A & & & & & A & & & & & & & A & & & & A & A & A & \\
\hline 299-W19-40 & CERC & 200UP1 & & & & & & & & & & & & & & & Q & & & & & Q & Q & \\
\hline 299-W19-40 & SURV & West & & & A & & & & & A & & & A & & & & A & & & & A & A & A & \\
\hline 299-W19-41 & RCRA & SST(U) & Q & A & Q & & & & & & A & & A & Qf & & & Q & & & & A & & A & \\
\hline 299-W19-41 & SURV & West & & & A & & & & & A & & & & & & & A & & & & A & & A & \\
\hline 299-W19-42 & RCRA & SST(U) & Q & A & Q & & & & & & A & & A & Qf & & & Q & & & & A & & A & \\
\hline 299-W19-42 & SURV & West & & A & A & & & & & A & & & & & & & A & & & & A & & & \\
\hline 299-W19-43 & CERC & 200UP1 & & & & & & & & & & & & & & & Q & & & & & $Q$ & $Q$ & Date of first sampling TBD. \\
\hline 299-W19-6 & SURV & West & & A & A & & A & & & A & & & & Af & & & & & & & A & & A & \\
\hline 299-W19-9 & SURV & West & & & A & & & & & A & & & & & & & A & & & & A & A & A & \\
\hline 299-W22-10 & RCRA & SST(S) & Q & & Q & & A & & & & A & & & Qf & & A & Q & & A & & Q & Q & & \\
\hline 299-W22-10 & SURV & West & & A & $A$ & & & & & A & & & A & & & $A$ & $A$ & & & & $A$ & & & \\
\hline 299-W22-2 & RCRA & SST(S) & Q & A & $Q$ & & A & & & & A & & & Qf & & A & $Q$ & & A & & Q & $Q$ & & \\
\hline 299-W22-2 & SURV & West & & & A & & & & & A & & & & & & A & A & & & & A & A & & \\
\hline 299-W22-20 & SURV & West & & $A$ & A & & A & & & A & A & & A & Af & & & A & & & & A & & A & \\
\hline 299-W22-26 & SURV & West & & A & A & & A & & & A & & & A & & & & A & & & & A & & A & \\
\hline 299-W22-44 & RCRA & SST(S) & Q & A & Q & & A & & & & A & & & Qf & & A & Q & & A & & Q & $Q$ & & \\
\hline 299-W22-45 & RCRA & SST(S) & $Q$ & A & $Q$ & & A & $\mathrm{Au}$ & & & A & & & Qf & & A & Q & & A & & Q & Q & & \\
\hline 299-W22-46 & RCRA & SST(S) & Q & A & Q & & A & $\mathrm{Au}$ & & & A & & & Qf & & A & Q & & A & & Q & Q & & \\
\hline 299-W22-48 & RCRA & SST(SX) & Q & A & Q & & A & & & & A & & & Qf & & A & Q & & A & & Q & Q & & \\
\hline 299-W22-48 & SURV & West & & & A & & & & & A & & & A & Af & & A & A & & & & A & & A & \\
\hline 299-W22-49 & RCRA & SST(SX) & Q & A & $Q$ & & A & & & & A & & & Qf & & A & Q & & A & & Q & Q & & \\
\hline 299-W22-49 & SURV & West & & & A & & & & & A & & & & & & & A & & & & A & & A & \\
\hline 299-W22-50 & RCRA & SST(SX) & $Q$ & A & Q & & A & & & & A & & & Qf & & A & Q & & A & & Q & Q & & \\
\hline 299-W22-50 & SURV & West & & & A & & & & & A & & & A & & & & A & & & & A & & & \\
\hline 299-W22-7 & SURV & West & & A & $A$ & & A & & & A & & & A & & & & & & & & A & & A & \\
\hline 299-W22-79 & RCRA & $\mathrm{U}-12$ & A & & $Q$ & & & & & & & & S & Af & & & Q & & & & A & & & \\
\hline 299-W22-80 & RCRA & SST(SX) & $Q$ & A & $Q$ & & A & & & & $\mathrm{S}$ & & & Qf & & $S$ & $Q$ & & A & & $Q$ & $Q$ & & \\
\hline
\end{tabular}




\begin{tabular}{|c|c|c|c|c|c|c|c|c|c|c|c|c|c|c|c|c|c|c|c|c|c|c|c|c|}
\hline WELL & PROG & PROJ & 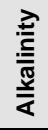 & $\frac{\frac{\pi}{2}}{\frac{0}{\alpha}}$ & $\frac{n}{0}$ & 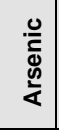 & $\begin{array}{l}\text { 离 } \\
\text { D. }\end{array}$ & 屯े & $\begin{array}{l}\frac{0}{0} \\
\frac{0}{\mathrm{C}} \\
\text { ปे }\end{array}$ & 음 & 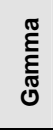 & $\begin{array}{l}\text { 유 } \\
\infty \\
\text { 오 }\end{array}$ & 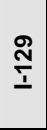 & $\underline{0}$ & $\begin{array}{l}\frac{\infty}{0} \\
\frac{\bar{\sigma}}{0} \\
\frac{c}{\alpha}\end{array}$ & $\begin{array}{l}\text { के } \\
\frac{1}{\omega}\end{array}$ & $\begin{array}{l}\stackrel{8}{8} \\
\text { ப் }\end{array}$ & 吕 & O & ’̊ & 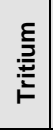 & 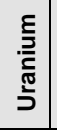 & ঠ & Other/comments \\
\hline 299-W22-81 & RCRA & SST(SX) & Q & A & $Q$ & & A & & & & $\mathrm{S}$ & & & Qf & & s & $Q$ & & A & & $Q$ & $Q$ & & \\
\hline 299-W22-82 & RCRA & SST(SX) & Q & A & $Q$ & & A & & & & $\mathrm{s}$ & & & Qf & & $\mathrm{s}$ & Q & & A & & $Q$ & Q & & \\
\hline 299-W22-83 & RCRA & SST(SX) & Q & A & Q & & A & & & & $\mathrm{S}$ & & & Qf & & $\mathrm{s}$ & Q & & A & & Q & Q & & \\
\hline 299-W22-9 & SURV & West & & & A & & & & & A & & & A & & & & & & & & A & & A & \\
\hline 299-W23-10 & SURV & West & & & A & & & & & A & & & & & & & A & & & & A & A & A & \\
\hline 299-W23-15 & RCRA & SST(S) & Q & A & Q & & A & $\mathrm{Au}$ & & & A & & & Qf & & A & Q & & A & & Q & Q & A & \\
\hline 299-W23-15 & SURV & West & & A & A & & & & & A & & & & Af & & & A & & & & A & A & A & \\
\hline 299-W23-19 & RCRA & SST(S) & Q & Q & Q & & Q & & Q & & Q & & Q & Qf & & Q & Q & & Q & & Q & Q & & \\
\hline 299-W23-19 & RCRA & SST(SX) & $Q$ & Q & Q & & Q & & & & Q & & Q & Qf & & Q & Q & & Q & & Q & Q & & \\
\hline 299-W23-20 & RCRA & SST(SX) & Q & A & Q & & A & & & & $\mathrm{s}$ & & & Qf & & $\mathrm{s}$ & $Q$ & & A & & Q & Q & & \\
\hline 299-W23-21 & RCRA & SST(SX) & Q & A & Q & & A & & & & $S$ & & & Qf & & $S$ & $\mathrm{Q}$ & & A & & $\mathrm{Q}$ & Q & & \\
\hline 299-W23-21 & SURV & West & & A & A & & & & & A & & & & & & & A & & & & A & & & \\
\hline 299-W23-4 & RCRA & SST(SX) & & & $\mathrm{A}$ & & & & & & & & & Af & & & $\mathrm{A}$ & & A & & A & A & A & \\
\hline 299-W23-4 & SURV & West & & $\mathrm{A}$ & A & & A & & & A & & & & & & & $\mathrm{A}$ & & & & A & A & & \\
\hline 299-W23-9 & SURV & West & & & A & & & & & A & & & A & & & & $\mathrm{A}$ & & & & A & A & & \\
\hline 299-W26-12 & RCRA & S-10 & A & A & $\mathrm{A}$ & & A & $\mathrm{Sf}$ & & & & & & Af & A & & & & A4 & A4 & & & & River transect \\
\hline 299-W26-12 & SURV & West & & & A & & & & & A & & & A & & & & A & & & & A & & A & \\
\hline 299-W26-13 & RCRA & S-10 & A & A & A & & A & $\mathrm{Sf}$ & & & & & & Af & A & & & & A4 & A4 & & & & \\
\hline 299-W26-13 & SURV & West & & & $A$ & & & & & A & & & & Af & & & & & & & A & & A & \\
\hline 299-W26-6 & SURV & West & & & $\mathrm{A}$ & & & & & $\mathrm{A}$ & & & & Af & & & & & & & & & $\mathrm{A}$ & Bottom unconfined. \\
\hline 299-W26-7 & RCRA & S-10 & A & A & A & & A & $\mathrm{Sf}$ & & & & & & Af & A & & & & A4 & A4 & & & & \\
\hline 299-W26-7 & SURV & West & & & $\mathrm{A}$ & & & & & A & & & & Af & & & & & & & & & A & \\
\hline 299-W27-1 & SURV & West & A & A & A & & A & & & A & & & A & & & & & & & & A & & & \\
\hline 299-W27-2 & RCRA & S-10 & A & & A & & & Sf & & & & & & Af & & & & & & & & & & Base of unconfined. \\
\hline 299-W27-2 & SURV & West & & & A & & & & & A & & & A & & & & & & & & A & A & A & \\
\hline 299-W6-10 & SURV & West & & $\mathrm{T}$ & $\mathrm{T}$ & & $\mathrm{T}$ & & & $\mathrm{T}$ & & & $\mathrm{T}$ & Tf & & & $\mathrm{T}$ & & & & $\mathrm{T}$ & & A & FY03 \\
\hline 299-W6-11 & O\&M & SALDS & & & & & & & & & & & & & & & & & & & A & & & \\
\hline 299-W6-12 & O\&M & SALDS & & & & & & & & & & & & & & & & & & & A & & & \\
\hline 299-W6-2 & SURV & West & & A & A & & A & & & A & & & A & & & & & & & & A & & A & \\
\hline 299-W6-3 & SURV & West & A & A & A & & & & & A & & & A & Af & & & A & & & & A & & A & Deep unconfined (b). \\
\hline 299-W6-4 & SURV & West & A & A & A & & & & & A & & & A & Af & & & A & & & & A & & A & \\
\hline
\end{tabular}




\begin{tabular}{|c|c|c|c|c|c|c|c|c|c|c|c|c|c|c|c|c|c|c|c|c|c|c|c|c|}
\hline WELL & PROG & PROJ & 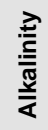 & $\frac{\frac{\pi}{0}}{\frac{0}{\alpha}}$ & $\frac{\mathscr{0}}{\frac{0}{c}}$ & 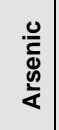 & 胥 & 屯ัँ & $\begin{array}{l}\frac{0}{\circ} \\
\frac{0}{\bar{\sigma}} \\
\text { Uे }\end{array}$ & ㅇ & 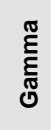 & $\begin{array}{l}\text { 유 } \\
\infty \\
\text { ㅁ }\end{array}$ & $\frac{\text { ని }}{1}$ & $\underline{0}$ & $\begin{array}{l}\frac{\infty}{0} \\
\frac{\sigma}{0} \\
\frac{5}{\alpha}\end{array}$ & $\begin{array}{l}\text { के } \\
\frac{1}{\omega}\end{array}$ & $\begin{array}{l}\stackrel{8}{\dot{d}} \\
\stackrel{0}{\circ}\end{array}$ & $\stackrel{\text { 足 }}{口}$ & O & 암 & 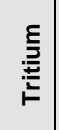 & 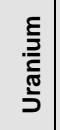 & ঠ্ & Other/comments \\
\hline 299-W6-6 & O\&M & SALDS & & & & & & & & & & & & & & & & & & & A & & & \\
\hline 299-W6-6 & SURV & West & A & A & A & & A & & & A & & & A & Af & & & & & & & A & & A & Deep unconfined (b). \\
\hline 299-W6-7 & O\&M & SALDS & & & & & & & & & & & & & & & & & & & A & & & \\
\hline 299-W6-7 & SURV & West & & & A & & & & & A & & & $A$ & & & & A & & & & A & & A & \\
\hline 299-W6-8 & O\&M & SALDS & & & & & & & & & & & & & & & & & & & A & & & \\
\hline 299-W7-1 & O\&M & SALDS & & & & & & & & & & & & & & & & & & & A & & & \\
\hline 299-W7-1 & RCRA & LLBG(3) & $\mathrm{s}$ & $\mathrm{s}$ & $\mathrm{s}$ & & $\mathrm{s}$ & & & & & $\mathrm{Sf}$ & & $\mathrm{Sf}$ & A & & & & S4 & S4 & $\mathrm{S}$ & & $\mathrm{s}$ & \\
\hline 299-W7-11 & O\&M & SALDS & & & & & & & & & & & & & & & & & & & $S$ & & & \\
\hline 299-W7-11 & RCRA & LLBG(3) & $S$ & $S$ & $S$ & & $S$ & & & & & $\mathrm{Sf}$ & & $\mathrm{Sf}$ & A & & & & S4 & S4 & $S$ & & $S$ & \\
\hline 299-W7-11 & SURV & West & & & A & & & & & A & & & & & & & & & & & & & A & \\
\hline 299-W7-12 & O\&M & SALDS & & & & & & & & & & & & & & & & & & & A & & & \\
\hline 299-W7-12 & RCRA & LLBG(3) & $S$ & $S$ & $S$ & & $S$ & & & & & $\mathrm{Sf}$ & & $\mathrm{Sf}$ & A & & & & S4 & S4 & $\mathrm{s}$ & & $S$ & \\
\hline 299-W7-12 & SURV & West & & & A & & & & & A & & & & & & & & & & & A & & A & \\
\hline 299-W7-3 & O\&M & SALDS & & & & & & & & & & & & & & & & & & & $S$ & & & \\
\hline 299-W7-3 & RCRA & LLBG(3) & $S$ & $S$ & $S$ & & $S$ & & & & & $\mathrm{Sf}$ & & $\mathrm{Sf}$ & A & & & & $S$ & $S$ & $S$ & & $S$ & Deep unconfined (b). \\
\hline 299-W7-3 & SURV & West & A & $\mathrm{A}$ & $\mathrm{A}$ & & A & & & $A$ & & & & Af & & & & & & & A & & A & Deep unconfined (b). \\
\hline 299-W7-4 & RCRA & LLBG(3) & $\mathrm{s}$ & $\mathrm{s}$ & $\mathrm{s}$ & & $S$ & & & & & $\mathrm{Sf}$ & & $\mathrm{Sf}$ & A & & & & S4 & S4 & $S$ & & $S$ & \\
\hline 299-W7-4 & SURV & West & & A & A & & A & & & A & & & & & & & & & & & A & & A & \\
\hline 299-W7-5 & O\&M & SALDS & & & & & & & & & & & & & & & & & & & $\mathrm{S}$ & & & \\
\hline 299-W7-5 & RCRA & LLBG(3) & $S$ & $S$ & $S$ & & $S$ & & & & & $\mathrm{Sf}$ & & $\mathrm{Sf}$ & $A$ & & & & S4 & S4 & $S$ & & $S$ & \\
\hline 299-W7-5 & SURV & West & & & A & & & & & A & & & & & & & & & & & & & $A$ & \\
\hline 299-W7-6 & O\&M & SALDS & & & & & & & & & & & & & & & & & & & $S$ & & & \\
\hline 299-W7-6 & SURV & West & & A & A & & $A$ & & & A & & & & & & & & & & & $\mathrm{A}$ & & A & \\
\hline 299-W7-7 & O\&M & SALDS & & & & & & & & & & & & & & & & & & & $\mathrm{s}$ & & & \\
\hline 299-W7-7 & RCRA & LLBG(3) & $S$ & $S$ & $S$ & & $S$ & & & & & $\mathrm{Sf}$ & & $\mathrm{Sf}$ & A & & & & S4 & S4 & $\mathrm{s}$ & & $S$ & \\
\hline 299-W7-8 & O\&M & SALDS & & & & & & & & & & & & & & & & & & & A & & & \\
\hline 299-W7-8 & RCRA & LLBG(3) & $S$ & $S$ & $S$ & & $S$ & & & & & $\mathrm{Sf}$ & & $\mathrm{Sf}$ & A & & & & S4 & S4 & S & & $S$ & \\
\hline 299-W7-8 & SURV & West & & & A & & & & & A & & & & & & & & & & & A & & A & \\
\hline 299-W7-9 & O\&M & SALDS & & & & & & & & & & & & & & & & & & & $\mathrm{A}$ & & & \\
\hline 299-W7-9 & RCRA & LLBG(3) & $S$ & $S$ & $S$ & & $\mathrm{~s}$ & & & & & $\mathrm{Sf}$ & & $\mathrm{Sf}$ & $A$ & & & & S4 & S4 & $S$ & & $S$ & \\
\hline 299-W8-1 & O\&M & SALDS & & & & & & & & & & & & & & & & & & & $A$ & & & \\
\hline
\end{tabular}




\begin{tabular}{|c|c|c|c|c|c|c|c|c|c|c|c|c|c|c|c|c|c|c|c|c|c|c|c|c|}
\hline WELL & PROG & PROJ & 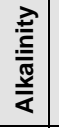 & $\frac{\frac{\pi}{2}}{\frac{0}{4}}$ & 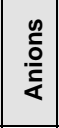 & 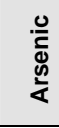 & 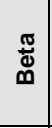 & 志 & $\begin{array}{l}\frac{0}{0} \\
\frac{\pi}{\overline{5}} \\
\text { ปे }\end{array}$ & ৪ & 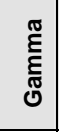 & 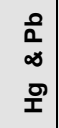 & 昰 & $\underline{\mathrm{O}}$ & $\left|\begin{array}{l}\frac{\infty}{0} \\
\frac{\bar{\sigma}}{0} \\
\frac{\Phi}{\alpha}\end{array}\right|$ & $\begin{array}{l}\stackrel{\$}{1} \\
\frac{1}{50}\end{array}$ & $\begin{array}{l}0 \\
\stackrel{0}{\dot{\varphi}} \\
\dot{r}\end{array}$ & $\stackrel{\mathscr{P}}{\vdash}$ & $\begin{array}{l}0 \\
0 \\
\vdash\end{array}$ & $\begin{array}{l}\text { × } \\
\stackrel{1}{*}\end{array}$ & $\underset{\underline{\underline{E}}}{\underline{E}}$ & 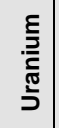 & § & Other/comments \\
\hline 299-W8-1 & RCRA & LLBG(3) & $\mathrm{s}$ & $\mathrm{s}$ & $\mathrm{s}$ & & $\mathrm{s}$ & & & & & Sf & & Sf & A & & & & S4 & S4 & $\mathrm{s}$ & & $\mathrm{s}$ & \\
\hline 299-W8-1 & SURV & West & & & A & & & & & A & & & & & & A & & & & & & & A & \\
\hline $3099-42-16$ & SURV & $\mathrm{RCHN}$ & & & A & & & & & A & & & & & & & & & & & A & & & \\
\hline $3099-47-18 B$ & SURV & $\mathrm{RCHN}$ & & & A & & & & & A & & & & & & & & & & & A & & & \\
\hline $399-1-10 \mathrm{~A}$ & RCRA & 300-APT & & & & & & & & & & & & & & & & & & & & Q & $\mathrm{Q}$ & \\
\hline $399-1-10 A$ & SURV & 300 & & & A & & & & & A & & & & & & & & & & & & & A & \\
\hline $399-1-10 B$ & RCRA & 300-APT & & & & & & & & & & & & & & & & & & & & $\mathrm{s}$ & $\mathrm{s}$ & \\
\hline $399-1-10 B$ & SURV & 300 & & & & & & & & A & & & & & & & & & & & A & & & \\
\hline $399-1-12$ & LTMC & $300 F F 5$ & & & & & & & & & & & & & & & & & & & & A & & \\
\hline $399-1-13 A$ & SURV & 300 & & & & & & & & A & & & & & & & & & & & A & & & \\
\hline $399-1-14 \mathrm{~A}$ & SURV & 300 & & & A & & & & & A & & & & & & & & & & & A & A & A & \\
\hline $399-1-16 A$ & RCRA & 300-APT & & & & & & & & & & & & & & & & & & & & $\mathrm{Q}$ & Q & \\
\hline $399-1-16 \mathrm{~A}$ & SURV & 300 & & & A & & & & & A & & & & & & & & & & & & & & \\
\hline $399-1-16 B$ & RCRA & 300-APT & & & & & & & & & & & & & & & & & & & & $\mathrm{Q}$ & $\mathrm{Q}$ & Deep unconfined (b). \\
\hline $399-1-16 B$ & SURV & 300 & & & & & & & & A & & & & & & & & & & & & & & Deep unconfined (b). \\
\hline $399-1-16 \mathrm{C}$ & SURV & 300 & & & & & & & & A & & & & & & & & & & & A & . & & \\
\hline $399-1-17 A$ & $\mathrm{DOH}$ & $300 \mathrm{DOH}$ & & $\mathrm{s}$ & $\mathrm{s}$ & & $\mathrm{s}$ & & & & $\mathrm{s}$ & & & & & & & & & & $\mathrm{s}$ & $\mathrm{s}$ & & S:Uiso \\
\hline $399-1-17 A$ & RCRA & 300-APT & & & & & & & & & & & & & & & & & & & & $\mathrm{Q}$ & $\mathrm{Q}$ & \\
\hline $399-1-17 A$ & SURV & 300 & & $\mathrm{~s}$ & $\mathrm{~s}$ & & $\mathrm{~s}$ & & & $\mathrm{~s}$ & & & A & & & & & & & & A & $\mathrm{s}$ & A & S:Uiso \\
\hline $399-1-17 B$ & RCRA & 300-APT & & & & & & & & & & & & & & & & & & & & $\mathrm{s}$ & $\mathrm{s}$ & Deep unconfined (b). \\
\hline $399-1-17 B$ & SURV & 300 & & & & & & & & A & & & & & & & & & & & & & & Deep unconfined (b). \\
\hline $399-1-18 \mathrm{~A}$ & RCRA & 300-APT & & & & & & & & & & & & & & & & & & & & $\mathrm{s}$ & $\mathrm{s}$ & \\
\hline $399-1-18 \mathrm{~A}$ & SURV & 300 & & & A & & & & & A & & & & & & & & & & & & & & \\
\hline $399-1-18 B$ & RCRA & 300-APT & & & & & & & & & & & & & & & & & & & & $\mathrm{s}$ & $\mathrm{s}$ & Deep unconfined (b). \\
\hline $399-1-18 B$ & SURV & 300 & & & & & & & & A & & & & & & & & & & & A & & & Deep unconfined (b). \\
\hline $399-1-18 \mathrm{C}$ & SURV & 300 & & & & & & & & A & & & & & & & & & & & A & & & \\
\hline $399-1-2$ & SURV & 300 & & & & & & & & A & & & & & & & & & & & & A & & \\
\hline $399-1-21 \mathrm{~A}$ & SURV & 300 & & & A & & & & & A & & & & & & & & & & & A & A & A & \\
\hline $399-1-3$ & SURV & 300 & & & & & & & & A & & & & & & & A & & & & & A & A & \\
\hline $399-1-6$ & LTMC & $300 F F 5$ & & & & & & & & & & & & & & & & & & & & A & & \\
\hline $399-1-7$ & LTMC & $300 F F 5$ & & & & & & & & & & & & & & & & & & & & A & A & \\
\hline
\end{tabular}




\begin{tabular}{|c|c|c|c|c|c|c|c|c|c|c|c|c|c|c|c|c|c|c|c|c|c|c|c|c|}
\hline WELL & PROG & PROJ & 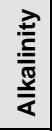 & $\frac{\frac{\pi}{2}}{\frac{0}{4}}$ & 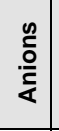 & 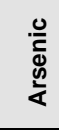 & 嵒 & 竞 & 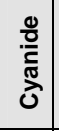 & ८ & 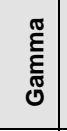 & $\begin{array}{l}0 \\
\infty \\
\infty \\
0 \\
\text { I }\end{array}$ & న্ণ & $\underline{\underline{0}}$ & $\begin{array}{l}\frac{\omega}{0} \\
\frac{\bar{\Phi}}{\alpha} \\
\frac{\pi}{\alpha}\end{array}$ & $\begin{array}{l}\frac{8}{1} \\
\frac{1}{\omega}\end{array}$ & $\mid \begin{array}{c}8 \\
\dot{0} \\
\dot{0}\end{array}$ & $\stackrel{0}{\circ}$ & : & ò & 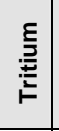 & 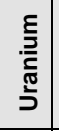 & § & Other/comments \\
\hline $399-1-8$ & SURV & 300 & & & & & & & & & & & & & & & & & & & & A & A & \\
\hline $399-2-1$ & LTMC & $300 F F 5$ & & & & & & & & & & & & & & & & & & & & A & & \\
\hline $399-2-1$ & SURV & 300 & & & & & & & & A & & & & & & & & & & & & . & A & \\
\hline $399-2-2$ & LTMC & $300 F F 5$ & & & & & & & & & & & & & & & & & & & & A & A & \\
\hline 399-3-1 & SURV & 300 & & & & & & & & A & & & & & & & & & & & & A & & \\
\hline $399-3-10$ & SURV & 300 & & & & & & & & A & & & & & & & & & & & & A & A & \\
\hline 399-3-11 & SURV & 300 & & $\mathrm{~s}$ & A & & $\mathrm{s}$ & & & $\mathrm{s}$ & & & & & & $A f / u$ & & & & & A & $\mathrm{s}$ & A & \\
\hline 399-3-12 & LTMC & $300 \mathrm{FF} 5$ & & & & & & & & & & & & & & & & & & & & A & & \\
\hline 399-3-12 & SURV & 300 & & & A & & & & & A & & & & & & & & & & & A & & . & \\
\hline $399-3-2$ & SURV & 300 & & & & & & & & A & & & & & & & & & & & & . & A & \\
\hline $399-3-3$ & SURV & 300 & & & & & & & & A & & & & & & & & & & & & A & A & \\
\hline $399-3-6$ & SURV & 300 & & & A & & & & & $s$ & & & & & & & & & & & $\mathrm{~s}$ & A & A & \\
\hline 399-4-1 & LTMC & $300 F F 5$ & & & & & & & & & & & & & & & & & & & & A & & \\
\hline $399-4-1$ & SURV & 300 & & & $\mathrm{~s}$ & & & & & $\mathrm{~s}$ & & & & & & & & & & & $\mathrm{~s}$ & & $\mathrm{~s}$ & \\
\hline $399-4-10$ & SURV & 300 & & & & & & & & A & & & & & & & & & & & & & A & \\
\hline $399-4-11$ & SURV & 300 & & & A & & & & & $\mathrm{s}$ & & & & & & & & & & & A & A & $\mathrm{s}$ & \\
\hline $399-4-12$ & LTMC & $300 F F 5$ & & & & & & & & & & & & & & & & & & & & A & A & \\
\hline $399-4-12$ & SURV & 300 & & & A & & & & & A & & & & & & & & & & & A & . & & \\
\hline $399-4-7$ & SURV & 300 & & & & & & & & $\mathrm{~s}$ & & & & & & & & & & & $\mathrm{~s}$ & A & A & \\
\hline 399-4-9 & LTMC & $300 F F 5$ & & & . & & & & & & & & & & & & & & & & 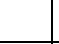 & A & & \\
\hline $399-4-9$ & SURV & 300 & & & A & & & & & A & & & & & & & & & & & A & A & A & \\
\hline $399-5-1$ & SURV & 300 & & & $\mathrm{~s}$ & & & & & $\mathrm{~s}$ & & & & & & & & & & & A & A & A & \\
\hline $399-5-2$ & SURV & Basalt & $\mathrm{T}$ & $\mathrm{T}$ & $\mathrm{T}$ & & $\mathrm{T}$ & & & $\mathrm{T}$ & & & & Tf & & & & & & & $\mathrm{T}$ & & & $\begin{array}{l}\text { FY04. Levey \& Elephant Mt. } \\
\text { Interflow (b). }\end{array}$ \\
\hline $399-5-4 B$ & SURV & 300 & & & & & & & & $\mathrm{~s}$ & & & & & & & & & & & A & & $\mathrm{s}$ & \\
\hline $399-6-1$ & SURV & 300 & & & & & & & & A & & & & & & & & & & & & & A & \\
\hline $399-6-2$ & SURV & 300 & & & & & & & & $s$ & & & & & & & & & & & & & $s$ & \\
\hline $399-8-1$ & SURV & 300 & & & & & & & & A & & & & & & & & & & & A & A & A & \\
\hline $399-8-5 A$ & SURV & 300 & & & A & & & & & A & & & & & & & & & & & A & A & A & \\
\hline $399-8-5 B$ & SURV & 300 & & & & & & & & A & & & & & & & & & & & A & & & Deep unconfined (b). \\
\hline $399-8-5 \mathrm{C}$ & SURV & 300 & & & & & & & & A & & & & & & & & & & & A & & & Deep unconfined (b). \\
\hline
\end{tabular}




\begin{tabular}{|c|c|c|c|c|c|c|c|c|c|c|c|c|c|c|c|c|c|c|c|c|c|c|c|c|}
\hline WELL & PROG & PROJ & 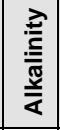 & $\frac{\frac{\pi}{0}}{\frac{0}{\alpha}}$ & $\begin{array}{l}n \\
\frac{n}{2} \\
\frac{0}{2}\end{array}$ & 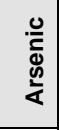 & ๘ँّ & 屯ัँ & $\begin{array}{l}\frac{0}{0} \\
\frac{0}{\mathrm{~J}} \\
\text { Jे }\end{array}$ & 음 & 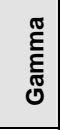 & $\begin{array}{l}0 \\
0 \\
\infty \\
\not{9}\end{array}$ & 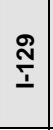 & $\underline{0}$ & 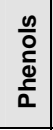 & $\begin{array}{l}\text { के } \\
\frac{1}{\omega}\end{array}$ & 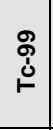 & $\stackrel{\mathscr{p}}{\circ}$ & 안 & ํㅗㅇ & 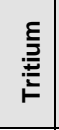 & 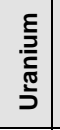 & § & Other/comments \\
\hline $499-50-7$ & SURV & 400 & A & A & A & & A & & & $\mathrm{M}$ & & & A & Af & & & & & & & M & & & A:Amm \\
\hline 499-S0-8 & SURV & 400 & A & A & A & & A & & & $\mathrm{M}$ & & & A & Af & & & & & & & $\mathrm{M}$ & & & \\
\hline 499-S1-8J & $\mathrm{DOH}$ & $400 \mathrm{DOH}$ & & A & A & & A & & & & A & & & & & A & A & & & & A & A & & A:Uiso. Drinking water well. \\
\hline 499-S1-8J & SURV & 400 & & A & A & & A & & & M & A & & A & Af & & A & A & & & & $\mathrm{M}$ & A & A & $\begin{array}{l}\text { A:Amm, Uiso. Drinking water } \\
\text { well }\end{array}$ \\
\hline $499-S 1-8 K$ & SURV & 400 & & A & A & & A & & & A & & & & & & & & & & & A & & & \\
\hline $699-10-54 \mathrm{~A}$ & SURV & East & $\mathrm{T}$ & A & A & & A & & & A & $\mathrm{T}$ & & & Tf & & $\mathrm{T}$ & $\mathrm{T}$ & & $\mathrm{T}$ & $\mathrm{T}$ & A & & & FY04. SE Transect \\
\hline 699-10-E12 & SURV & East & $\mathrm{A}$ & A & A & & A & & & A & $\mathrm{A}$ & & & Af & & A & A & & $\mathrm{A}$ & A & A & & & River transect \\
\hline 699-1-18 & SURV & East & & & $\mathrm{T}$ & & & & & $\mathrm{T}$ & & & & & & & & & & & $\mathrm{T}$ & & & FY04 \\
\hline 699-12-4D & SURV & East & & & $\mathrm{T}$ & & & & & $\mathrm{T}$ & & & $\mathrm{T}$ & & & & & & & & $\mathrm{T}$ & & & FY04. 618-11 burial ground \\
\hline $699-13-1 A$ & SURV & East & & $\mathrm{T}$ & $\mathrm{T}$ & & $\mathrm{T}$ & & & $\mathrm{T}$ & & & $\mathrm{T}$ & & & & & & & & $\mathrm{T}$ & & & FY04. 618-11 burial ground \\
\hline $699-13-1 C$ & SURV & Basalt & $\mathrm{T}$ & $\mathrm{T}$ & $\mathrm{T}$ & & $\mathrm{T}$ & & & $\mathrm{T}$ & & & & Tf & & & & & & & $\mathrm{T}$ & & & $\begin{array}{l}\text { FY03. Elephan Mt interflow \& } \\
\text { Rattlesnake Ridge interbed (b). }\end{array}$ \\
\hline 699-13-3A & CERC & $300 F F 5$ & & A & & & A & & & & & & & Af/u & & & & & & & A & A & & \\
\hline 699-13-3A & SURV & East & & & & & & & & A & A & & & & & & & & & & A & & A & A:Ni-63. $618-11$ burial ground \\
\hline 699-14-38 & SURV & East & & & $\mathrm{T}$ & & & & & $\mathrm{T}$ & & & & Tf & & & & & & & $\mathrm{T}$ & & & FY04 \\
\hline $699-17-5$ & SURV & East & $\mathrm{T}$ & $\mathrm{T}$ & $\mathrm{T}$ & & $\mathrm{T}$ & & & $\mathrm{T}$ & $\mathrm{T}$ & & $\mathrm{T}$ & Tf & & $\mathrm{T}$ & $\mathrm{T}$ & & & & $\mathrm{T}$ & & $\mathrm{T}$ & FY04. 618-11 burial ground \\
\hline 699-17-70 & SURV & West & & & A & & & & & A & & & & & & & & & & & A & & & \\
\hline 699-19-43 & SURV & East & & & $\mathrm{T}$ & & & & & $\mathrm{T}$ & & & $\mathrm{T}$ & Tf & & & & & & & $\mathrm{T}$ & & & FY04 \\
\hline 699-19-58 & SURV & West & $\mathrm{T}$ & & $\mathrm{T}$ & & & & & $\mathrm{T}$ & & & & Tf & & & & & & & $\mathrm{T}$ & & & FY04 \\
\hline 699-19-88 & SURV & West & & Q & A & & Q & & $\mathrm{T}$ & $Q$ & & & & Af/u & & & & & Q & Q & A & & $Q$ & FY03 T:CN \\
\hline $699-20-20$ & SURV & East & & $\mathrm{T}$ & $\mathrm{T}$ & & $\mathrm{T}$ & & & $\mathrm{T}$ & $\mathrm{T}$ & & $\mathrm{T}$ & Tf & & & $\mathrm{T}$ & & & & $\mathrm{T}$ & & & FY04 \\
\hline 699-20-E12O & SURV & East & A & A & A & & A & & & A & A & & A & Af & & A & A & & A & A & A & & & River transect \\
\hline 699-20-E12S & SURV & East & $\mathrm{T}$ & & $\mathrm{T}$ & & & & & $\mathrm{T}$ & & & & & & & & & & & $\mathrm{T}$ & & & FY04. Deep unconfined (b). \\
\hline 699-20-E5A & SURV & East & & & $\mathrm{T}$ & & & & & $\mathrm{T}$ & & & & & & & & & & & $\mathrm{T}$ & & & FY04 \\
\hline $699-21-6$ & SURV & East & & & $\mathrm{T}$ & & & & & $\mathrm{T}$ & & & $\mathrm{T}$ & & & & & & & & $\mathrm{T}$ & & & FY04. 618-11 burial ground \\
\hline 699-22-35 & RCRA & SWL & & & Q & Qf & & & & & & & & Qf & & & & & Q & Q & & & $Q$ & Q:Amm, COD, col \\
\hline 699-22-35 & SURV & East & & & $\mathrm{T}$ & & & & & $\mathrm{T}$ & & & $\mathrm{T}$ & & & & & & & & $\mathrm{T}$ & & & FY04 \\
\hline 699-22-70 & SURV & Basalt & $\mathrm{T}$ & & $\mathrm{T}$ & & & & & $\mathrm{T}$ & & & & Tf & & & & & & & $\mathrm{T}$ & & & $\begin{array}{l}\text { FY03. Upper Saddle Mts. } \\
\text { Basalt (b). }\end{array}$ \\
\hline 699-2-3 & SURV & East & & & $T$ & & & & & $\mathrm{~T}$ & & & $\mathrm{~T}$ & & & & & & & & $\mathrm{~T}$ & & & FY04 \\
\hline 699-23-34A & RCRA & SWL & & & Q & Qf & & & & & & & & Qf & & & & & Q & Q & & & Q & Q:Amm, COD, col \\
\hline
\end{tabular}




\begin{tabular}{|c|c|c|c|c|c|c|c|c|c|c|c|c|c|c|c|c|c|c|c|c|c|c|c|c|}
\hline WELL & PROG & PROJ & 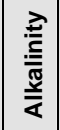 & $\frac{\frac{\pi}{0}}{\frac{0}{\alpha}}$ & $\frac{\mathscr{0}}{\frac{0}{c}}$ & 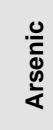 & ஹूّ & 屯ัँ & $\begin{array}{l}\frac{0}{\circ} \\
\frac{0}{\mathrm{~T}} \\
\text { ปे }\end{array}$ & 웅 & 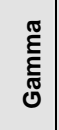 & $\begin{array}{l}0 \\
0 \\
\infty \\
\text { ㅇ }\end{array}$ & 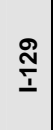 & $\underline{0}$ & $\begin{array}{l}\frac{\infty}{0} \\
\frac{\sigma}{0} \\
\frac{5}{\alpha}\end{array}$ & $\begin{array}{l}\text { के } \\
\frac{1}{\omega}\end{array}$ & 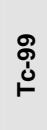 & 足 & O & 암 & 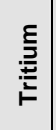 & 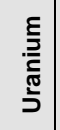 & § & Other/comments \\
\hline 699-23-34B & RCRA & SWL & & & Q & Qf & & & & & & & & Qf & & & & & Q & Q & & & Q & Q:Amm, COD, col \\
\hline 699-24-1P & SURV & Basalt & $\mathrm{T}$ & $\mathrm{T}$ & $\mathrm{T}$ & & $\mathrm{T}$ & & & $\mathrm{T}$ & & & & Tf & & & & & & & $\mathrm{T}$ & & & $\begin{array}{l}\text { FY04. Rattlesnake Ridge } \\
\text { Interbed \& Pomona basalt (b). }\end{array}$ \\
\hline $699-24-33$ & RCRA & SWL & & & Q & Qf & & & & & & & & Qf & & & & & $Q$ & $Q$ & & & Q & Q:Amm, COD, col \\
\hline 699-24-34A & RCRA & SWL & & & $Q$ & Qf & & & & & & & & Qf & & & & & $Q$ & $Q$ & & & $Q$ & Q:Amm, COD, col \\
\hline 699-24-34B & RCRA & SWL & & & $Q$ & Qf & & & & & & & & Qf & & & & & Q & Q & & & Q & Q:Amm, COD, col \\
\hline 699-24-34C & RCRA & SWL & & & $Q$ & Qf & & & & & & & & Qf & & & & & $Q$ & $Q$ & & & $\mathrm{Q}$ & Q:Amm, COD, col \\
\hline 699-24-34C & SURV & East & & & $\mathrm{T}$ & & & & & $T$ & & & $T$ & & & & & & & & $T$ & & & FY04 \\
\hline 699-24-35 & RCRA & SWL & & & $Q$ & Qf & & & & & & & & Qf & & & & & $Q$ & Q & & & $Q$ & Q:Amm, COD, col \\
\hline 699-24-46 & SURV & East & A & A & A & & A & & & A & A & & $\mathrm{T}$ & Af & & A & A & & $A$ & A & A & & & FY04. SE Transect \\
\hline 699-25-33A & RCRA & NRDW & & & $\mathrm{s}$ & & & & & & & & & Af & A & & & & $S$ & $S$ & & & $S$ & Bottom unconfined. \\
\hline 699-25-34A & RCRA & NRDW & & & $\mathrm{s}$ & & & & & & & & & Af & A & & & & S4 & S4 & & & $S$ & \\
\hline 699-25-34B & RCRA & NRDW & & & $\mathrm{s}$ & & & & & & & & & Af & A & & & & S4 & S4 & & & $\mathrm{s}$ & \\
\hline $699-25-34 \mathrm{C}$ & RCRA & SWL & & & $Q$ & Qf & & & & & & & & Qf & & & & & $Q$ & $Q$ & & & $Q$ & Q:Amm, COD, col \\
\hline 699-25-34D & RCRA & NRDW & & & $S$ & & & & & & & & & Af & A & & & & S4 & S4 & & & $S$ & \\
\hline 699-25-70 & SURV & West & & & $\mathrm{T}$ & & & & & $\mathrm{T}$ & & & $\mathrm{T}$ & Tf & & & & & & & $\mathrm{T}$ & & & FY03 \\
\hline 699-26-15A & SURV & East & & & $T$ & & & & & $\mathrm{~T}$ & & & $T$ & & & & & & & & $T$ & & & FY04 \\
\hline 699-26-33 & $\mathrm{DOH}$ & $600 \mathrm{DOH}$ & & A & A & & $A$ & & & & A & & & & & $A$ & A & & & & A & & & \\
\hline 699-26-33 & RCRA & NRDW & & & $\mathrm{s}$ & & & & & & & & & Af & $A$ & & & & S4 & S4 & & & $\mathrm{S}$ & \\
\hline 699-26-33 & SURV & East & A & $\mathrm{A}$ & A & & $A$ & & & A & A & & & Af & & A & A & & A & A & A & & & SE Transect \\
\hline 699-26-34A & RCRA & NRDW & & & $S$ & & & & & & & & & Af & A & & & & S4 & S4 & & & $S$ & \\
\hline 699-26-34B & RCRA & NRDW & & & $\mathrm{s}$ & & & & & & & & & Af & $\mathrm{A}$ & & & & S4 & $\mathrm{S} 4$ & & & $\mathrm{~s}$ & \\
\hline 699-26-35A & RCRA & SWL & & & $Q$ & Qf & & & & & & & & Qf & A & & & & $Q$ & $Q$ & & & $Q$ & Q:Amm, COD, col \\
\hline 699-26-35A & SURV & East & & & $T$ & & & & & $\mathrm{~T}$ & & & $\mathrm{~T}$ & & & & & & & & $T$ & & & FY04 \\
\hline 699-26-35C & RCRA & NRDW & & & $\mathrm{s}$ & & & & & & & & & Af & A & & & & $S$ & $S$ & & & $S$ & Bottom unconfined. \\
\hline 699-26-89 & SURV & West & & & $\mathrm{T}$ & & & & & $\mathrm{T}$ & & & & & & & & & & & $\mathrm{T}$ & & & FY03 \\
\hline 699-2-6A & FFTF & 400 FFTF & & & & & & Qu & & & & $\mathrm{Qu}$ & & Qu & & & & $Q$ & $Q$ & & & & & Q:Cd, SO4 \\
\hline $699-2-6 \mathrm{~A}$ & SURV & 400 & $Q$ & A & $Q$ & & $A$ & & & $Q$ & & Af & & Af & & & & & $Q$ & & A & & & A:Col \\
\hline $699-2-7$ & FFTF & 400 FFTF & & & & & & $\mathrm{Qu}$ & & & & $\mathrm{Qu}$ & & Qu & & & & Q & $Q$ & & & & & Q:Cd, SO4 \\
\hline \begin{tabular}{|l|}
$699-2-7$ \\
\end{tabular} & SURV & 400 & $Q$ & A & $Q$ & & A & & & $Q$ & & Af & & Af & & & & & $Q$ & & A & & & A:Col \\
\hline $699-27-8$ & SURV & East & & & $\mathrm{T}$ & & & & & $T$ & & & $\mathrm{~T}$ & & & & & & & & $T$ & & & FY04 \\
\hline
\end{tabular}




\begin{tabular}{|c|c|c|c|c|c|c|c|c|c|c|c|c|c|c|c|c|c|c|c|c|c|c|c|c|}
\hline WELL & PROG & PROJ & 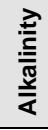 & $\frac{\frac{\pi}{2}}{\frac{0}{\alpha}}$ & 号 & 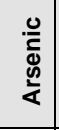 & Фూ & $\begin{array}{l}+ \\
\text { ஸे }\end{array}$ & 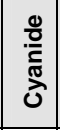 & 8 & 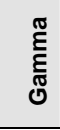 & $\begin{array}{l}0 \\
\infty \\
\infty \\
\text { ㅁ }\end{array}$ & 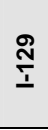 & $\underline{0}$ & $\begin{array}{l}\frac{0}{0} \\
\frac{0}{\Phi} \\
\frac{C}{0}\end{array}$ & $\begin{array}{l}\text { क् } \\
\frac{1}{\omega}\end{array}$ & $\begin{array}{l}\text { ஓ } \\
\text { 으 }\end{array}$ & $\stackrel{0}{\circ}$ & 옴 & ํㅗㅁ & 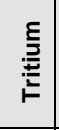 & 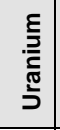 & § & Other/comments \\
\hline $699-28-40$ & SURV & East & & & $\mathrm{T}$ & & & & & $\mathrm{T}$ & & & $\mathrm{T}$ & Tf & & & & & & & $\mathrm{T}$ & & & FY04 \\
\hline 699-29-4 & SURV & East & & & $\mathrm{T}$ & & & & & $\mathrm{T}$ & & & $\mathrm{T}$ & & & & & & & & $\mathrm{T}$ & & & FY04 \\
\hline 699-31-11 & SURV & East & & & $\mathrm{T}$ & & & & & $\mathrm{T}$ & & & $\mathrm{T}$ & & & & & & & & $\mathrm{T}$ & & & FY04 \\
\hline 699-31-31 & $\mathrm{DOH}$ & $600 \mathrm{DOH}$ & & A & A & & A & & & & A & & & & & A & A & & & & A & & & \\
\hline 699-31-31 & SURV & East & $\mathrm{A}$ & A & A & & $\mathrm{A}$ & & & A & A & & & Af & & A & A & & $\mathrm{A}$ & A & A & & & SE Transect \\
\hline 699-31-31P & SURV & East & & & $\mathrm{T}$ & & & & & $\mathrm{T}$ & & & $\mathrm{T}$ & & & & & & & & $T$ & & & FY04. Confined Ringold (b). \\
\hline 699-32-22A & SURV & East & A & A & A & & A & & & A & A & & & Af & & A & A & & A & A & A & & & SE Transect \\
\hline 699-32-22B & SURV & Basalt & $\mathrm{T}$ & $\mathrm{T}$ & $\mathrm{T}$ & & $\mathrm{T}$ & & & $\mathrm{T}$ & & & $\mathrm{T}$ & Tf & & & & & & & $\mathrm{T}$ & & & $\begin{array}{l}\text { FY03. Rattlesnake Ridge } \\
\text { Interbed (b). }\end{array}$ \\
\hline 699-32-43 & SURV & East & A & A & A & & A & & & A & A & & A & Af & & A & A & & A & A & A & & & SE Transect \\
\hline 699-32-62 & SURV & West & & & $\mathrm{T}$ & & & & & $\mathrm{T}$ & & & $\mathrm{T}$ & Tf & & & & & & & $\mathrm{T}$ & & & FY03 \\
\hline 699-32-70B & SURV & West & & & $\mathrm{T}$ & & & & & $\mathrm{T}$ & & & $\mathrm{T}$ & & & & & & & & $\mathrm{T}$ & & $\mathrm{T}$ & FY03 \\
\hline 699-32-72A & SURV & West & & & $\mathrm{T}$ & & & & & $\mathrm{T}$ & & & $\mathrm{T}$ & & & & & & & & $T$ & & $\mathrm{~T}$ & FY03 \\
\hline 699-33-42 & SURV & East & & & $\mathrm{T}$ & & & & & $\mathrm{T}$ & & & $\mathrm{T}$ & Tf & & & & & & & $\mathrm{T}$ & & & FY04 \\
\hline 699-33-56 & SURV & West & & & $\mathrm{T}$ & & & & & $\mathrm{T}$ & & & & $\mathrm{Tf}$ & & & & & & & $\mathrm{T}$ & & & FY03 \\
\hline 699-34-41B & SURV & East & & & A & & & & & A & & & A & & & & & & & & A & & & \\
\hline 699-34-42 & SURV & East & & & $\mathrm{T}$ & & & & & $\mathrm{T}$ & & & $\mathrm{T}$ & & & & & & & & $\mathrm{T}$ & & & FY04 \\
\hline 699-34-61 & SURV & West & & & $\mathrm{T}$ & & & & & $\mathrm{T}$ & & & $\mathrm{T}$ & Tf & & & & & & & $\mathrm{T}$ & & & FY03 \\
\hline 699-34-88 & SURV & West & & & $\mathrm{T}$ & & $\mathrm{T}$ & & & $\mathrm{T}$ & & & & & & & & & & & $\mathrm{T}$ & & $\mathrm{T}$ & FY03 \\
\hline 699-35-66A & CERC & ERDF & $S$ & $S$ & $\mathrm{~s}$ & & $\mathrm{~s}$ & & & & & & $S$ & & & & $S$ & $S$ & & $S$ & & $S$ & $\mathrm{~s}$ & See note (a). \\
\hline 699-35-66A & SURV & West & & & A & & & & & A & & & A & & & & & & & & A & & $\mathrm{A}$ & \\
\hline 699-35-70 & $\mathrm{DOH}$ & $600 \mathrm{DOH}$ & & $S$ & $S$ & & $\mathrm{~S}$ & & & & $S$ & & $S$ & & & & $\mathrm{~s}$ & & & & $S$ & $S$ & & S:Uiso \\
\hline 699-35-70 & SURV & West & A & $S$ & $S$ & & $S$ & & & $S$ & $S$ & & $S$ & $\mathrm{Sf}$ & & & A & & & & $S$ & $S$ & $S$ & S:Uiso \\
\hline 699-35-78A & SURV & West & $\mathrm{A}$ & & $\mathrm{A}$ & & $A$ & & & $\mathrm{~A}$ & & & & Af & & & A & & & & & A & $A$ & \\
\hline 699-35-9 & SURV & East & & & $T$ & & & & & $\mathrm{~T}$ & & & $\mathrm{~T}$ & & & & & & & & $\mathrm{~T}$ & & & FY04 \\
\hline 699-36-61A & SURV & West & & & $\mathrm{T}$ & & & & & $\mathrm{T}$ & & & $\mathrm{T}$ & Tf & & & & & & & $\mathrm{T}$ & & & FY03 \\
\hline 699-36-67 & CERC & ERDF & $S$ & $S$ & $S$ & & $S$ & & & & & & $S$ & & & & $S$ & $S$ & & $S$ & & $S$ & $S$ & See note (a). \\
\hline 699-36-67 & SURV & West & & & A & & & & & A & & & A & & & & & & & & A & & $\mathrm{A}$ & \\
\hline 699-36-70A & CERC & ERDF & $S$ & $\mathrm{~s}$ & $\mathrm{~s}$ & & $S$ & & & & & & $S$ & & & & $\mathrm{~s}$ & $S$ & & $\mathrm{~s}$ & & $S$ & $S$ & See note (a). \\
\hline 699-36-70A & RCRA & $\mathrm{U}-12$ & $\mathrm{~A}$ & & $Q$ & & & & & & & & $S$ & $\mathrm{Sf}$ & & & $\mathrm{Q}$ & & $\mathrm{s}$ & $S$ & Q & & & \\
\hline 699-36-70A & SURV & West & & & $T$ & & & & & $\mathrm{~T}$ & & & & & & & & & & & $T$ & & $\mathrm{~T}$ & FY03 \\
\hline
\end{tabular}




\begin{tabular}{|c|c|c|c|c|c|c|c|c|c|c|c|c|c|c|c|c|c|c|c|c|c|c|c|c|}
\hline WELL & PROG & PROJ & 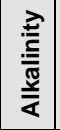 & $\frac{\pi}{\frac{\pi}{2}}$ & $\frac{n}{0}$ & 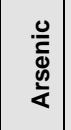 & ळ్ & さे & 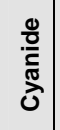 & 음 & 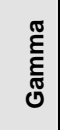 & $\begin{array}{l}\stackrel{0}{0} \\
\infty \\
\text { 옹 }\end{array}$ & 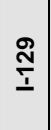 & $\stackrel{0}{0}$ & $\begin{array}{l}\frac{\infty}{0} \\
\frac{\sigma}{0} \\
\frac{0}{\alpha}\end{array}$ & $\begin{array}{l}\text { क् } \\
\frac{1}{\omega}\end{array}$ & $\begin{array}{l}\stackrel{8}{:} \\
\stackrel{0}{\circ}\end{array}$ & $\stackrel{\mathscr{c}}{P}$ & O & 음 & 疍 & 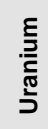 & § & Other/comments \\
\hline $699-36-93$ & SURV & West & & & $\mathrm{T}$ & & & & & $\mathrm{T}$ & & & & & & & & & & & $\mathrm{T}$ & & & FY03 \\
\hline $699-37-43$ & SURV & East & & & $T$ & & & & & $T$ & & & $\mathrm{~T}$ & & & & & & & & $T$ & & & FY04 \\
\hline 699-37-47A & RCRA & PUREX & $S$ & $S$ & $S$ & Sf & $S$ & & & & & & $S$ & $\mathrm{Sf}$ & $S$ & $S$ & & & & & $S$ & & & S:Amm \\
\hline 699-37-47A & SURV & East & & & $\mathrm{T}$ & Tf & & & & $\mathrm{T}$ & & & $\mathrm{T}$ & & & & & & & & $\mathrm{T}$ & & & FY04 \\
\hline 699-37-68 & CERC & ERDF & $S$ & $S$ & $S$ & & $S$ & & & & & & $S$ & & & & $\mathrm{~s}$ & $\mathrm{~s}$ & & $\mathrm{~s}$ & & $\mathrm{~s}$ & $\mathrm{~s}$ & See note (a). \\
\hline 699-37-68 & SURV & West & & & A & & & & & A & & & A & & & & & & & & A & & A & \\
\hline 699-37-82A & SURV & West & & & $T$ & & & & & $\mathrm{~T}$ & & & & & & & & & & & $\mathrm{~T}$ & & $\mathrm{~T}$ & FY03 \\
\hline 699-37-E4 & SURV & East & $\mathrm{T}$ & & $T$ & & & & & $T$ & & & $\mathrm{~T}$ & Tf & & & & & & & $\mathrm{T}$ & & & FY04 \\
\hline 699-38-15 & SURV & East & & & $\mathrm{T}$ & & & & & $\mathrm{T}$ & & & $T$ & & & & & & & & $\mathrm{~T}$ & & & FY04 \\
\hline 699-38-65 & SURV & West & & A & A & & $A$ & & & A & A & & A & Af & & & A & & & & A & A & A & A:Uiso \\
\hline 699-38-68A & SURV & West & A & & A & & $\mathrm{A}$ & & & A & & & & Af & & & & & & & A & & $A$ & \\
\hline 699-38-70 & SURV & West & & & A & & & & & A & & & A & & & & A & & & & A & A & A & \\
\hline 699-39-39 & SURV & East & & & $\mathrm{T}$ & & & & & $\mathrm{T}$ & & & $\mathrm{T}$ & & & & & & & & $\mathrm{T}$ & & & FY04 \\
\hline 699-39-79 & CERC & 200ZP1 & & & & & & & & & & & $A$ & & & & A & & & & A & & A & \\
\hline 699-39-79 & SURV & West & & & & & & & & $\mathrm{T}$ & & & & & & & $\mathrm{T}$ & & & & $T$ & & $\mathrm{~T}$ & FY03 \\
\hline 699-40-1 & SURV & East & & & $T$ & & & & & $T$ & & & $T$ & & & & & & & & $T$ & & & FY04 \\
\hline 699-40-33A & SURV & East & & & $T$ & & & & & $T$ & & & $T$ & & & & & & & & $\mathrm{~T}$ & & & FY04 \\
\hline 699-40-36 & O\&M & TEDF & $\mathrm{Q}$ & Q & $Q$ & Qf/u & Q & Qf/u & & & & Qf/u & & Qf/u & & & & Q & & & A & & & Q: $\mathrm{Cd}$ \\
\hline $699-40-62$ & SURV & West & & & $\mathrm{T}$ & & & & & $\mathrm{T}$ & & & $T$ & & & & & & & & $T$ & & & FY03 \\
\hline $699-41-1 \mathrm{~A}$ & $\mathrm{DOH}$ & $600 \mathrm{DOH}$ & & A & A & & A & & & & A & & A & & & A & A & & & & A & & & \\
\hline $699-41-1 A$ & SURV & East & A & A & A & & A & & & A & A & & A & Af & & A & A & & A & A & A & & & River transect \\
\hline 699-41-23 & SURV & East & $\mathrm{T}$ & A & A & & A & & & A & $\mathrm{T}$ & & & $\mathrm{Tf}$ & & $T$ & $\mathrm{~T}$ & & $\mathrm{~T}$ & $\mathrm{~T}$ & A & & & FY04. SE Transect \\
\hline 699-41-35 & O\&M & TEDF & $\mathrm{Q}$ & $Q$ & $Q$ & Qf/u & $Q$ & Qf/u & & & & Qf/u & & Qf/u & & & & $\mathrm{Q}$ & & & A & & & Q: Cd \\
\hline 699-41-40 & SURV & East & $T$ & $T$ & $\mathrm{~T}$ & & $T$ & & & $\mathrm{~T}$ & & & $\mathrm{~T}$ & & & & & & & & $\mathrm{~T}$ & & & FY04. Confined Ringold (b). \\
\hline $699-42-12 A$ & SURV & East & & & $T$ & & & & & $T$ & & & $T$ & & & & & & & & $T$ & & & FY04 \\
\hline 699-42-37 & $\mathrm{O} \& \mathrm{M}$ & TEDF & $Q$ & $Q$ & $Q$ & Qf/u & Q & Qf/u & & & & Qf/u & & Qf/u & & & & $Q$ & & & A & & & Q: Cd \\
\hline $699-42-39 A$ & SURV & East & & & $T$ & & & & & $\mathrm{~T}$ & & & $\mathrm{~T}$ & & & & & & & & $\mathrm{~T}$ & & & FY04 \\
\hline 699-42-39B & SURV & East & $\mathrm{T}$ & & $T$ & & & & & $T$ & & & $T$ & & & & & & & & $\mathrm{~T}$ & & & FY04. Confined Ringold (b). \\
\hline $699-42-40 \mathrm{C}$ & SURV & Basalt & $\mathrm{T}$ & $\mathrm{T}$ & $\mathrm{T}$ & & $\mathrm{T}$ & & & $\mathrm{T}$ & & & $\mathrm{T}$ & Tf & & & & & & & $\mathrm{T}$ & & & $\begin{array}{l}\text { FY03. Rattlesnake Ridge } \\
\text { Interbed (b). }\end{array}$ \\
\hline $699-42-41$ & SURV & East & & & $T$ & Tf & & & & $\mathrm{T}$ & & & $\mathrm{T}$ & & & & & & & & $\mathrm{T}$ & & & FY04. Confined Ringold (b). \\
\hline
\end{tabular}




\begin{tabular}{|c|c|c|c|c|c|c|c|c|c|c|c|c|c|c|c|c|c|c|c|c|c|c|c|c|}
\hline WELL & PROG & PROJ & 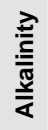 & $\frac{\frac{\pi}{2}}{\frac{2}{\alpha}}$ & $\frac{\mathscr{0}}{\frac{0}{c}}$ & 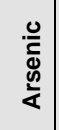 & 丞 & 屯ัँ & 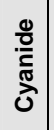 & 음 & 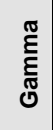 & $\begin{array}{l}0 \\
\infty \\
\infty \\
\text { 오 }\end{array}$ & 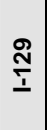 & $\underline{0}$ & $\begin{array}{l}\frac{\infty}{0} \\
\frac{\Phi}{\Phi} \\
\frac{5}{\alpha}\end{array}$ & $\begin{array}{l}8 \\
\frac{1}{\omega} \\
\text { की }\end{array}$ & $\begin{array}{l}\stackrel{8}{\grave{d}} \\
\stackrel{\circ}{\circ}\end{array}$ & $\stackrel{\mathscr{P}}{\boldsymbol{P}}$ & O & ํㅗㅁ & 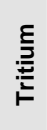 & 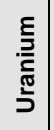 & §̊ & Other/comments \\
\hline $699-42-42 B$ & RCRA & BPOND & $\mathrm{s}$ & $\mathrm{s}$ & A & & $\mathrm{s}$ & & & $\mathrm{s}$ & & & & Af & A & & & & S4 & S4 & A & & & Confined Ringold (b). \\
\hline $699-42-42 B$ & SURV & East & $T$ & & T & & & & & T & & & $T$ & & & & & & & & $\mathrm{~T}$ & & & FY04. Confined Ringold (b). \\
\hline 699-42-E9B & $\mathrm{DOH}$ & $600 \mathrm{DOH}$ & & A & A & & A & & & & A & & A & & & & & & & & A & A & & $\begin{array}{l}\text { A:Uiso. E of river. Upper } \\
\text { Saddle Mts. Basalt (b). }\end{array}$ \\
\hline 699-42-E9B & SURV & Basalt & A & A & A & & A & & & A & A & & A & Af & & & & & & & A & & & $\begin{array}{l}\text { A:Uiso. E of river. Upper } \\
\text { Saddle Mts. Basalt (b). }\end{array}$ \\
\hline 699-43-3 & SURV & East & & & $\mathrm{T}$ & & & & & $T$ & & & $T$ & & & & & & & & $T$ & & & FY04 \\
\hline $699-43-40$ & SURV & East & & & $\mathrm{T}$ & Tf & & & & $T$ & & & $T$ & & & & & & & & $\mathrm{~T}$ & & & FY04 \\
\hline 699-43-41E & SURV & East & & & $T$ & $\mathrm{Tf}$ & & & & $T$ & & & $T$ & & & & & & & & $T$ & & & FY04. Confined Ringold (b). \\
\hline $699-43-43$ & RCRA & A-29 & $S$ & & $\mathrm{~s}$ & & & & & & & & & Af & A & & & & S4 & S4 & & & & \\
\hline 699-43-43 & SURV & East & & & $T$ & Tf & & & & $T$ & & & $T$ & & & & & & & & $\mathrm{~T}$ & & & FY04 \\
\hline $699-43-44$ & RCRA & BPOND & $\mathrm{s}$ & $\mathrm{s}$ & $A$ & & $\mathrm{~s}$ & & & S & & & & Af & A & & & & S4 & S4 & $A$ & & & \\
\hline $699-43-45$ & RCRA & A-29 & $\mathrm{s}$ & & $\mathrm{s}$ & & & & & & & & & Af & $A$ & & & & S4 & S4 & & & & \\
\hline $699-43-45$ & RCRA & BPOND & $\mathrm{s}$ & S & A & & S & & & $S$ & & & & Af & $A$ & & & & S4 & S4 & A & & & \\
\hline $699-43-45$ & SURV & East & & & $T$ & $\mathrm{Tf}$ & & & & $T$ & & & $T$ & & & & & & & & $T$ & & & FY04 \\
\hline 699-43-89 & SURV & West & & & $T$ & & & & & $T$ & & & & & & & & & & & $\mathrm{~T}$ & & $\mathrm{~T}$ & FY03 \\
\hline 699-44-39B & RCRA & BPOND & $S$ & $S$ & A & & $\mathrm{s}$ & & & S & & & & Af & A & & & & S4 & S4 & A & & & \\
\hline 699-44-39B & SURV & East & & & $T$ & & & & & $\mathrm{~T}$ & & & $T$ & & & & & & & & $\mathrm{~T}$ & & & FY04 \\
\hline 699-44-64 & SURV & West & & A & A & & A & & & A & A & & A & & & & A & & & & A & A & A & \\
\hline 699-45-42 & SURV & East & & & $T$ & & & & & $T$ & & & $T$ & & & & & & & & $T$ & & & FY04 \\
\hline 699-45-69A & SURV & West & & & A & & & & & A & & & A & Af & & & & & & & $\mathrm{A}$ & A & A & \\
\hline 699-46-21B & SURV & East & $T$ & A & A & & A & & & A & $T$ & & & Tf & & $T$ & $T$ & & $T$ & $\mathrm{~T}$ & A & & & FY04. SE Transect \\
\hline 699-46-4 & SURV & East & A & A & A & & A & & & A & A & & A & Af & & A & A & & A & A & A & & & River transect \\
\hline $699-47-5$ & SURV & East & & & $T$ & & & & & $T$ & & & $T$ & & & & & & & & $T$ & & & FY04 \\
\hline 699-47-60 & CERC & 200ZP1 & & & & & & & & & & & & & & & & & & & & & A & \\
\hline 699-47-60 & SURV & West & & & $A$ & & & & A & A & & & A & & & & $A$ & & & & A & A & A & \\
\hline 699-48-71 & O\&M & SALDS & & & & & & & & & & & & & & & & & & & $A$ & & & \\
\hline 699-48-71 & SURV & West & & & A & & & & & A & & & A & Af & & & & & & & A & & A & \\
\hline 699-48-77A & O\&M & SALDS & Q & $\mathrm{Q}$ & & & $Q$ & & & & & $\mathrm{Qu}$ & & Qu & & $Q$ & & $Q$ & & & $Q$ & & & Q: CdU, DO, SO4 \\
\hline 699-48-77A & SURV & West & & & A & & & & & $\mathrm{T}$ & & & & & & A & & & & & $\mathrm{A}$ & & A & FY03 \\
\hline 699-48-77C & O\&M & SALDS & $\mathrm{Q}$ & $Q$ & & & Q & & & & & $\mathrm{Qu}$ & & $\mathrm{Qu}$ & & Q & & Q & & & $\mathrm{Q}$ & & & Q: CdU, DO, SO4 \\
\hline 699-48-77C & SURV & West & & & A & & & & & & & & & & & $A$ & & & & & A & & A & \\
\hline
\end{tabular}




\begin{tabular}{|c|c|c|c|c|c|c|c|c|c|c|c|c|c|c|c|c|c|c|c|c|c|c|c|c|}
\hline WELL & PROG & PROJ & 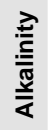 & $\frac{\frac{\pi}{0}}{\frac{0}{4}}$ & $\frac{\mathscr{0}}{\frac{0}{c}}$ & 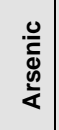 & 丞 & ডั๋ & $\begin{array}{l}\frac{0}{\circ} \\
\frac{0}{\bar{\sigma}} \\
\text { Uे }\end{array}$ & ㅇ & 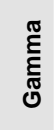 & $\begin{array}{l}0 \\
0 \\
\infty \\
ㅁ \\
\text { I }\end{array}$ & $\frac{\text { N }}{\underline{I}}$ & $\underline{0}$ & $\begin{array}{l}\frac{0}{0} \\
\frac{0}{0} \\
\frac{5}{\alpha}\end{array}$ & $\begin{array}{l}\text { के } \\
\frac{1}{\omega}\end{array}$ & 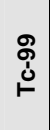 & $\stackrel{\text { 足 }}{\circ}$ & 음 & 啹 & 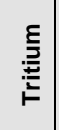 & 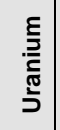 & § & Other/comments \\
\hline 699-48-77D & O\&M & SALDS & $Q$ & $Q$ & & & $Q$ & & & & & Qu & & Qu & & $Q$ & & Q & & & Q & & & Q: CdU, DO, SO4 \\
\hline 699-48-77D & SURV & West & & & A & & & & & & & & & & & A & & & & & A & & A & \\
\hline 699-48-7A & SURV & East & & & & & & & & $\mathrm{T}$ & & & & & & & & & & & $\mathrm{T}$ & & & FY04 \\
\hline 699-49-100C & $\mathrm{DOH}$ & $600 \mathrm{DOH}$ & & A & A & & $A$ & & & & A & & & & & & & & & & A & & & \\
\hline 699-49-100C & SURV & West & & $Q$ & $\mathrm{~A}$ & & $Q$ & & & $\mathrm{Q}$ & $Q$ & & Q & Af & & Q & Q & & Q & Q & A & Q & $\mathrm{Q}$ & A:Usio; Q:Puis \\
\hline 699-49-13E & SURV & East & & $T$ & $T$ & & $\mathrm{~T}$ & & & $\mathrm{~T}$ & $T$ & & $T$ & & & & & & & & $\mathrm{~T}$ & & & FY04 \\
\hline $699-49-55 \mathrm{~A}$ & LTMC & 200BP5 & & & & & & & $\mathrm{T}$ & & & & & & & & $\mathrm{T}$ & & & & & & & \\
\hline $699-49-55 A$ & SURV & Central & & & $\mathrm{T}$ & & $\mathrm{T}$ & & $\mathrm{T}$ & $\mathrm{T}$ & & & $\mathrm{T}$ & & & & $\mathrm{T}$ & & & & $\mathrm{T}$ & & & FY02 \\
\hline 699-49-55B & SURV & Central & $\mathrm{T}$ & $\mathrm{T}$ & $\mathrm{T}$ & & $\mathrm{T}$ & & $\mathrm{T}$ & $\mathrm{T}$ & $\mathrm{T}$ & & $\mathrm{T}$ & $\mathrm{Tf}$ & & & $\mathrm{T}$ & & & & $\mathrm{T}$ & & & FY03 \\
\hline 699-49-57A & LTMC & 200BP5 & & & & & & & A & & A & & & & & & A & & & & & & & \\
\hline 699-49-57A & SURV & Central & & & $T$ & Tf & & & $\mathrm{T}$ & $\mathrm{T}$ & $T$ & & $T$ & & & & $T$ & & & & $T$ & & & FY02 \\
\hline 699-49-57B & LTMC & 200BP5 & & & & & & & & & $\mathrm{T}$ & & & & & & $T$ & & & & & & & \\
\hline 699-49-57B & SURV & Basalt & $\mathrm{T}$ & $\mathrm{T}$ & $\mathrm{T}$ & & $\mathrm{T}$ & & & $\mathrm{T}$ & & & $\mathrm{T}$ & $\mathrm{Tf}$ & & & $\mathrm{T}$ & & & & $\mathrm{T}$ & & & $\begin{array}{l}\text { FY04. Rattlesnake Ridge } \\
\text { Interbed (b). }\end{array}$ \\
\hline 699-49-79 & O\&M & SALDS & & & & & & & & & & & & & & & & & & & $\mathrm{A}$ & & & \\
\hline \begin{tabular}{|l|}
$699-49-79$ \\
\end{tabular} & SURV & West & & & $\mathrm{T}$ & & & & & $\mathrm{T}$ & & & & & & & & & & & $\mathrm{T}$ & & $T$ & FY03 \\
\hline 699-50-28B & SURV & East & & & $T$ & & & & & $\mathrm{~T}$ & & & $T$ & & & & & & & & $T$ & & & FY04 \\
\hline 699-50-53A & LTMC & 200BP5 & & & $T$ & & & & $\mathrm{~T}$ & & & & & & & & $\mathrm{~T}$ & & & & & & & \\
\hline 699-50-53A & SURV & Central & & & $\mathrm{T}$ & & $T$ & & $T$ & $\mathrm{~T}$ & & & $T$ & & & & $\mathrm{~T}$ & & & & $T$ & & & FY02 \\
\hline 699-50-53B & SURV & Basalt & $\mathrm{T}$ & $\mathrm{T}$ & $\mathrm{T}$ & & $\mathrm{T}$ & & $\mathrm{T}$ & $\mathrm{T}$ & & & $\mathrm{T}$ & Tf & & & $\mathrm{T}$ & & & & $\mathrm{T}$ & $\mathrm{T}$ & & $\begin{array}{l}\text { FY03. Rattlesnake Ridge } \\
\text { Interbed (b). T:Uiso }\end{array}$ \\
\hline 699-50-85 & SURV & West & & & $T$ & & & & & $T$ & & & & & & & & & & & $T$ & & $T$ & FY03 \\
\hline 699-51-63 & SURV & West & & & A & Af & A & & A & A & A & & A & & & & A & & & & A & & A & \\
\hline 699-51-75 & $O \& M$ & SALDS & & & & & & & & & & & & & & & & & & & $S$ & & & \\
\hline 699-51-75 & SURV & West & & & $\mathrm{T}$ & & & & & $\mathrm{T}$ & & & & & & & & & & & $\mathrm{T}$ & & $\mathrm{T}$ & FY03 \\
\hline 699-51-75P & O\&M & SALDS & & & & & & & & & & & & & & & & & & & A & & & \\
\hline 699-52-19 & SURV & Central & & & $T$ & & & & & $T$ & & & & & & & & & & & $T$ & & & FY04 \\
\hline $699-52-46 A$ & SURV & Basalt & $\mathrm{T}$ & $\mathrm{T}$ & $\mathrm{T}$ & & $\mathrm{T}$ & & & $\mathrm{T}$ & & & & Tf & & $\mathrm{T}$ & & & & & $\mathrm{T}$ & & & $\begin{array}{l}\text { FY04. Rattlesnake Ridge } \\
\text { Interbed (b). }\end{array}$ \\
\hline 699-53-47A & LTMC & 200BP5 & & & A & & & & & & & & & & & A & & & & & & & & \\
\hline \begin{tabular}{|c|}
$699-53-47 A$ \\
\end{tabular} & SURV & Central & & A & $\mathrm{A}$ & & A & & & A & & & & & & A & & & & & A & & & \\
\hline 699-53-47B & LTMC & 200BP5 & & & $T$ & & & & & & & & & & & $\mathrm{~T}$ & & & & & & & & \\
\hline
\end{tabular}




\begin{tabular}{|c|c|c|c|c|c|c|c|c|c|c|c|c|c|c|c|c|c|c|c|c|c|c|c|c|}
\hline WELL & PROG & PROJ & 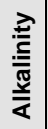 & $\frac{\frac{\pi}{0}}{\frac{0}{\alpha}}$ & 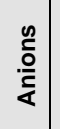 & 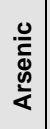 & 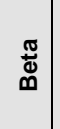 & 屯ัँ & $\begin{array}{l}\frac{0}{0} \\
\stackrel{0}{\frac{\pi}{5}} \\
\text { తิ }\end{array}$ & 옴 & 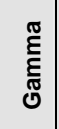 & $\begin{array}{l}\text { 오 } \\
\infty \\
\text { 오 }\end{array}$ & $\frac{\mathfrak{T}}{\underline{I}}$ & $\underline{\underline{0}}$ & 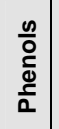 & $\begin{array}{l}\text { के } \\
\text { के }\end{array}$ & $\begin{array}{l}\stackrel{\circ}{0} \\
\stackrel{0}{\circ}\end{array}$ & $\stackrel{\mathscr{P}}{\boldsymbol{R}}$ & O & 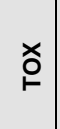 & 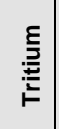 & 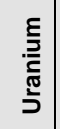 & §̊ & Other/comments \\
\hline 699-53-47B & SURV & Central & $T$ & $T$ & $T$ & & $T$ & & $T$ & $T$ & $T$ & & $T$ & Tf & & $T$ & $T$ & & & & T & & & FY02. T:Uiso \\
\hline 699-53-48A & LTMC & 200BP5 & & & $T$ & & & & & & & & & & & $T$ & & & & & & & & \\
\hline 699-53-48A & SURV & Central & & & $\mathrm{T}$ & & $\mathrm{T}$ & & & $\mathrm{T}$ & & & $\mathrm{T}$ & Tf & & $\mathrm{T}$ & & & & & $\mathrm{T}$ & & & FY02 \\
\hline 699-53-48B & LTMC & 200BP5 & & & & & & & & & & & & & & $T$ & & & & & & & & \\
\hline 699-53-48B & SURV & Central & & & $T$ & & $T$ & & & $T$ & & & & & & $T$ & & & & & T & & & FY02 \\
\hline $699-53-55 A$ & LTMC & 200BP5 & & & & & & & & & & & & & & & T & & & & & & & \\
\hline 699-53-55A & SURV & Central & & & $\mathrm{T}$ & & & & $T$ & $\mathrm{~T}$ & $\mathrm{~T}$ & & & & & & $\mathrm{~T}$ & & & & $\mathrm{~T}$ & & & FY02 \\
\hline 699-53-55B & LTMC & 200BP5 & & & & & & & & & & & & & & & $\mathrm{T}$ & & & & & & & \\
\hline 699-53-55B & SURV & Central & & & $T$ & & & & $\mathrm{~T}$ & $\mathrm{~T}$ & $T$ & & & & & & $T$ & & & & $\mathrm{~T}$ & & & FY02 \\
\hline 699-53-55C & LTMC & 200BP5 & & & & & & & & & & & & & & & $T$ & & & & & & & \\
\hline 699-53-55C & SURV & Central & & & $T$ & & & & T & T & T & & & & & & $T$ & & & & T & & & FY02 \\
\hline 699-54-34 & SURV & Basalt & $\mathrm{T}$ & $\mathrm{T}$ & $\mathrm{T}$ & & $\mathrm{T}$ & & & $\mathrm{T}$ & & & & Tf & & & & & & & $\mathrm{T}$ & & & $\begin{array}{l}\text { FY04. Upper Saddle Mts. } \\
\text { Basalt (b). }\end{array}$ \\
\hline 699-54-49 & LTMC & 200BP5 & & & & & & & & & & & & & & T & & & & & & & & \\
\hline 699-54-49 & SURV & Central & & & $\mathrm{T}$ & & $\mathrm{T}$ & & & $\mathrm{T}$ & & & & & & $T$ & & & & & $\mathrm{~T}$ & & & FY02 \\
\hline 699-55-57 & LTMC & 200BP5 & & & $T$ & & & & $\mathrm{~T}$ & & $\mathrm{~T}$ & & & & & & $\mathrm{~T}$ & & & & & & & \\
\hline 699-55-57 & SURV & Central & & & $T$ & & & & $T$ & $T$ & $T$ & & $T$ & & & & $T$ & & & & $\mathrm{~T}$ & & & FY02 \\
\hline 699-55-60A & LTMC & 200BP5 & & & $T$ & & & & $T$ & & $\mathrm{~T}$ & & & & & & $\mathrm{~T}$ & & & & & & & \\
\hline 699-55-60A & CERC & 200ZP1 & & & & & & & & & & & & & & & & & & & & & A & \\
\hline $699-55-60 \mathrm{~A}$ & SURV & Central & & $\mathrm{T}$ & $\mathrm{T}$ & & $\mathrm{T}$ & & $\mathrm{T}$ & $\mathrm{T}$ & $\mathrm{T}$ & & $\mathrm{T}$ & & & & $\mathrm{T}$ & & & & $\mathrm{T}$ & & & FY02 \\
\hline 699-55-76 & SURV & West & & & $T$ & & $\mathrm{~T}$ & & & $T$ & & & & & & & & & & & $T$ & & & FY03 \\
\hline 699-55-89 & SURV & West & & & $T$ & & & & & $\mathrm{~T}$ & & & & & & & & & & & $T$ & & $T$ & FY03 \\
\hline $699-56-43$ & SURV & Basalt & $\mathrm{T}$ & T & $\mathrm{T}$ & & $\mathrm{T}$ & & & $\mathrm{T}$ & & & & Tf & & & & & & & $\mathrm{T}$ & & & $\begin{array}{l}\text { FY03. Upper Saddle Mts. } \\
\text { Basalt (b). }\end{array}$ \\
\hline 699-56-53 & SURV & Basalt & $T$ & $T$ & $\mathrm{~T}$ & & $\mathrm{~T}$ & & & $\mathrm{~T}$ & & & & Tf & & & & & & & $\mathrm{T}$ & & & $\begin{array}{l}\text { FY03. Rattlesnake Ridge } \\
\text { Interbed (b). }\end{array}$ \\
\hline 699-57-59 & LTMC & 200BP5 & & & A & & & & & & A & & & & & & A & & & & & & & \\
\hline 699-57-59 & SURV & Central & A & A & $A$ & & A & & & A & $\mathrm{A}$ & & A & Af & & A & A & & A & A & A & & & Gap transect \\
\hline 699-59-58 & LTMC & 200BP5 & & & & & & & & & & & & & & & A & & & & & & & \\
\hline 699-59-58 & SURV & Central & A & A & A & & A & & & $\mathrm{A}$ & A & & A & Af & & A & A & & A & A & A & & & Gap transect \\
\hline 699-60-60 & $\mathrm{DOH}$ & $600 \mathrm{DOH}$ & & A & $\mathrm{A}$ & & A & & & & A & & & & & A & A & & & & A & & & \\
\hline 699-60-60 & SURV & Central & A & $A$ & $A$ & & $A$ & & & A & A & & A & Af & & $A$ & A & & A & A & A & & & Gap transect \\
\hline
\end{tabular}




\begin{tabular}{|c|c|c|c|c|c|c|c|c|c|c|c|c|c|c|c|c|c|c|c|c|c|c|c|c|}
\hline WELL & PROG & PROJ & 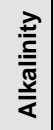 & $\frac{\frac{\pi}{0}}{\frac{0}{\alpha}}$ & $\frac{\mathscr{0}}{\frac{0}{c}}$ & 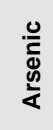 & 胥 & 屯ัँ & $\begin{array}{l}\frac{0}{0} \\
\frac{0}{5} \\
\text { ปे }\end{array}$ & 음 & 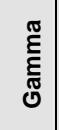 & $\begin{array}{l}\stackrel{0}{\alpha} \\
\infty \\
\mathbb{I}\end{array}$ & $\frac{\text { N }}{\underline{I}}$ & $\stackrel{0}{0}$ & $\begin{array}{l}\frac{n}{0} \\
\frac{0}{\Phi} \\
\frac{5}{0}\end{array}$ & $\begin{array}{l}\text { के } \\
\frac{1}{\omega}\end{array}$ & $\begin{array}{l}\stackrel{8}{P} \\
\text { 巳 }\end{array}$ & 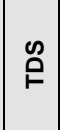 & O & 옴 & 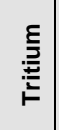 & 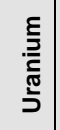 & ঠ̊ & Other/comments \\
\hline $699-61-62$ & SURV & Central & A & A & A & & A & & & A & A & & A & Af & & A & A & & A & A & A & & & Gap transect \\
\hline 699-61-66 & SURV & Central & A & $A$ & A & & $A$ & & & A & A & & $A$ & Af & & A & A & & $A$ & A & A & & & Gap transect \\
\hline 699-62-43F & SURV & $100 \mathrm{~F}$ & $\mathrm{~T}$ & & $T$ & & & & & $\mathrm{~T}$ & & & & $\mathrm{Tf}$ & & & & & & & $\mathrm{T}$ & & & FY02 \\
\hline 699-63-58 & SURV & $100 \mathrm{~B}$ & $T$ & & $T$ & & & & & $\mathrm{~T}$ & & & $T$ & $\mathrm{Tf}$ & & & & & & & $T$ & & & FY02 \\
\hline 699-63-90 & SURV & $100 \mathrm{~B}$ & $\mathrm{~T}$ & $T$ & $\mathrm{~T}$ & & $T$ & & & $\mathrm{~T}$ & $T$ & & $\mathrm{~T}$ & $\mathrm{Tf}$ & & & & & & & $\mathrm{T}$ & & $\mathrm{T}$ & FY02 \\
\hline \begin{tabular}{|l|}
$699-64-27$ \\
\end{tabular} & SURV & $100 \mathrm{~F}$ & $T$ & & $T$ & & & & & $\mathrm{~T}$ & & & $T$ & $\mathrm{Tf}$ & & & & & & & $T$ & & $T$ & FY02 \\
\hline 699-64-62 & SURV & Central & A & A & $\mathrm{A}$ & & A & & & $A$ & A & & & Af & & A & A & & A & A & A & & & Gap transect \\
\hline 699-65-50 & SURV & $100 \mathrm{~F}$ & $\mathrm{~T}$ & & $T$ & & & & & $\mathrm{~T}$ & & & $\mathrm{~T}$ & $\mathrm{Tf}$ & & & $\mathrm{T}$ & & & & $\mathrm{T}$ & & & FY02 \\
\hline 699-65-72 & SURV & $100 \mathrm{~B}$ & $\mathrm{~T}$ & & $\mathrm{~T}$ & & & & & $\mathrm{~T}$ & & & & $\mathrm{Tf}$ & & & & & & & $\mathrm{T}$ & & & FY02 \\
\hline 699-65-83 & LTMC & 100BC5 & & $\mathrm{B}$ & $B$ & & $B$ & & & & & & & $\mathrm{Bf} / \mathrm{u}$ & & $B$ & & & & & $\mathrm{~B}$ & & & FY02 \\
\hline 699-66-23 & SURV & $100 \mathrm{~F}$ & $T$ & & $T$ & & & & & $T$ & & & $T$ & $\mathrm{Tf}$ & & & & & & & $T$ & & $\mathrm{~T}$ & FY02 \\
\hline 699-66-58 & SURV & $100 \mathrm{~B}$ & & & $T$ & & & & & $T$ & & & $T$ & & & & $\mathrm{~T}$ & & & & $T$ & & & FY02 \\
\hline 699-66-64 & SURV & $100 \mathrm{~B}$ & & & $\mathrm{~T}$ & & & & & $\mathrm{~T}$ & & & $\mathrm{~T}$ & & & & $\mathrm{~T}$ & & & & $\mathrm{~T}$ & & & FY02 \\
\hline 699-67-86 & LTMC & 100BC5 & & $B$ & $B$ & & $\mathrm{~B}$ & & & & & & & $\mathrm{Bf} / \mathrm{u}$ & & $\mathrm{B}$ & & & & & $B$ & & & FY02 \\
\hline 699-67-86 & SURV & $100 \mathrm{~B}$ & $T$ & & $\mathrm{~T}$ & & & & & $\mathrm{~T}$ & & & & $\mathrm{Tf}$ & & & & & & & $\mathrm{T}$ & & & FY02 \\
\hline \begin{tabular}{|c|}
$699-70-68$ \\
\end{tabular} & CERC & 100KR4 & & $B$ & $B$ & & $B$ & & & & $B$ & & & $\mathrm{Bf} / \mathrm{u}$ & & & & & & & B & & & FY02 \\
\hline 699-70-68 & SURV & $100 \mathrm{~K}$ & & & $\mathrm{~A}$ & & A & & & $A$ & & & & & & & A & & & & A & & & \\
\hline 699-71-30 & LTMC & 100FR3 & & B & B & & B & & & & & & & $\mathrm{Bf} / \mathrm{u}$ & & B & & & & & B & & $B$ & FY03 \\
\hline 699-71-30 & SURV & $100 \mathrm{~F}$ & $\mathrm{~T}$ & & $T$ & & & & & $\mathrm{~T}$ & & & & $\mathrm{Tf}$ & & & & & & & $T$ & & $T$ & FY02 \\
\hline \begin{tabular}{|c|}
$699-72-73$ \\
\end{tabular} & LTMC & 100BC5 & & A & A & & $A$ & & & & & & & $\mathrm{Af}$ & & $\mathrm{A}$ & & & & & A & & & \\
\hline \begin{tabular}{|l|}
$699-72-73$ \\
\end{tabular} & SURV & $100 \mathrm{~K}$ & & & A & & $A$ & & & A & & & & & & & A & & & & $A$ & & & \\
\hline 699-72-92 & LTMC & 100BC5 & & B & $B$ & & $B$ & & & & & & & $\mathrm{Bf}$ & & B & & & & & $B$ & & & FY02 \\
\hline \begin{tabular}{|l|}
$699-72-92$ \\
\end{tabular} & SURV & $100 \mathrm{~B}$ & $\mathrm{~T}$ & & $\mathrm{~T}$ & & & & & $\mathrm{~T}$ & & & & $\mathrm{Tf}$ & & & & & & & $\mathrm{T}$ & & & FY02 \\
\hline 699-73-61 & CERC & 100KR4 & & $B$ & $B$ & & $B$ & & & & $B$ & & & $\mathrm{Bf} / \mathrm{u}$ & & & & & & & $B$ & & & FY02 \\
\hline 699-77-36 & LTMC & 100FR3 & $B$ & $\mathrm{~B}$ & $B$ & & $B$ & & & & & & & $\mathrm{Bf}$ & & $B$ & & & & & $B$ & & $B$ & FY02. B:C14 \\
\hline 699-77-36 & SURV & $100 \mathrm{~F}$ & $T$ & & $T$ & & & & & $\mathrm{~T}$ & & & & $\mathrm{Tf}$ & & & & & & & $T$ & & $T$ & FY02 \\
\hline \begin{tabular}{|c|}
$699-78-62$ \\
\end{tabular} & CERC & 100KR4 & & $B$ & B & & $B$ & & & & $B$ & & & $\mathrm{Bf} / \mathrm{u}$ & & & & & & & B & & & FY02 \\
\hline 699-81-38 & LTMC & 100FR3 & & $B$ & $B$ & & $B$ & & & & & & & $\mathrm{Bf} / \mathrm{u}$ & & $B$ & & & & & $B$ & & $B$ & FY03 \\
\hline 699-81-58 & SURV & $100 \mathrm{~N}$ & $\mathrm{~T}$ & & $\mathrm{~T}$ & & & & & & & & & $\mathrm{Tf}$ & & & & & & & $\mathrm{T}$ & & & FY02 \\
\hline $699-8-17$ & FFTF & 400 FFTF & & & & & & $\mathrm{Qu}$ & & & & $\mathrm{Qu}$ & & Qu & & & & $Q$ & $Q$ & & & & & Q:Cd, SO4 \\
\hline 699-8-17 & SURV & East & $Q$ & $A$ & $Q$ & & A & & & $Q$ & & Af & A & Af & & & & & $Q$ & & A & & & A:Col. $618-11$ burial ground \\
\hline
\end{tabular}




\begin{tabular}{|c|c|c|c|c|c|c|c|c|c|c|c|c|c|c|c|c|c|c|c|c|c|c|c|c|}
\hline WELL & PROG & PROJ & 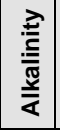 & $\frac{\pi}{\frac{0}{0}}$ & 号 & 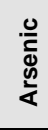 & $\begin{array}{l}\text { Фँ } \\
\text { Ф }\end{array}$ & 屯े & $\begin{array}{l}\frac{0}{0} \\
\frac{0}{5} \\
\text { ปे }\end{array}$ & 음 & 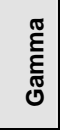 & $\begin{array}{l}\stackrel{0}{0} \\
\infty \\
\text { 오 }\end{array}$ & 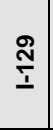 & $\underline{0}$ & $\begin{array}{l}\frac{\infty}{0} \\
\frac{\Phi}{\Phi} \\
\frac{\hbar}{\alpha}\end{array}$ & $\begin{array}{l}\text { के } \\
\frac{1}{\omega}\end{array}$ & $\begin{array}{l}\stackrel{8}{\dot{d}} \\
\dot{0}\end{array}$ & $\stackrel{\mathscr{P}}{口}$ & 옹 & 암 & 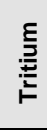 & 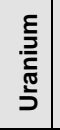 & ঠ & Other/comments \\
\hline 699-8-25 & SURV & East & & & $\mathrm{T}$ & & & & & T & & & $\mathrm{T}$ & & & & & & & & $\mathrm{T}$ & & & FY04 \\
\hline 699-83-47 & LTMC & 100FR3 & & B & B & & B & & & & & & & $B f / u$ & & B & & & & & B & & B & FY02 \\
\hline 699-83-47 & SURV & $100 \mathrm{~F}$ & B & & B & & & & & B & & & & $\mathrm{Bf}$ & & & & & & & B & & & FY02 \\
\hline 699-84-35A & LTMC & 100FR3 & & B & B & & B & & & & & & & Bf/u & & B & & & & & B & & B & FY03 \\
\hline 699-87-55 & SURV & $100 \mathrm{D}$ & $\mathrm{T}$ & & $\mathrm{T}$ & & & & & & & & & Tf & & & & & & & $\mathrm{T}$ & & & FY02 \\
\hline 699-89-35 & SURV & $100 \mathrm{H}$ & $\mathrm{T}$ & & $\mathrm{T}$ & & & & & $\mathrm{T}$ & & & & Tf & & & & & & & $\mathrm{T}$ & & & FY02 \\
\hline 699-91-46A & CERC & 100HR3 & & B & B & & B & & & & & & & $\mathrm{Bf} / \mathrm{u}$ & & & & & & & B & & & FY02 \\
\hline 699-91-46A & SURV & $100 \mathrm{H}$ & B & & $B$ & & & & & & & & & $\mathrm{Bf}$ & & & & & & & B & & & FY02 \\
\hline 699-93-48A & CERC & 100HR3 & & B & B & & B & & & & & & & $\mathrm{Bf} / \mathrm{u}$ & & & & & & & B & & & FY02 \\
\hline 699-96-43 & CERC & $100 \mathrm{HR} 3$ & & B & B & & B & & & & & & & Bf/u & & & & & & & B & & & FY03 \\
\hline 699-96-43 & SURV & $100 \mathrm{H}$ & & & & & & & & & & & & $\mathrm{Tf}$ & & & & & & & & & & FY02 \\
\hline 699-96-49 & CERC & 100HR3 & & B & B & & $\mathrm{B}$ & & & & & & & $\mathrm{Bf} / \mathrm{u}$ & & & & & & & B & & & FY03 \\
\hline 699-96-49 & SURV & $100 \mathrm{D}$ & B & & $B$ & & & & & & & & & $\mathrm{Bf}$ & & & & & & & B & & & FY03 \\
\hline 699-97-43 & CERC & 100HR3 & & $\mathrm{B}$ & B & & B & & & & & & & $\mathrm{Bf} / \mathrm{u}$ & & & & & & & B & & & FY02 \\
\hline 699-97-43 & SURV & $100 \mathrm{H}$ & A & & A & & & & & & & & & Af & & & & & & & A & & & \\
\hline 699-97-51A & CERC & 100HR3 & & A & A & & A & & & & & & & Af/u & & & & & & & A & & & \\
\hline 699-9-E2 & SURV & East & & $\mathrm{T}$ & $\mathrm{T}$ & & $\mathrm{T}$ & & & $\mathrm{T}$ & $\mathrm{T}$ & & $\mathrm{T}$ & & & & & & & & $\mathrm{T}$ & & & FY04. $618-11$ burial ground \\
\hline 699-S11-E12AP & SURV & East & $\mathrm{T}$ & $\mathrm{T}$ & $\mathrm{T}$ & & $\mathrm{T}$ & & & $\mathrm{T}$ & & & & Tf & & & & & & & $\mathrm{T}$ & & & FY03 \\
\hline 699-S12-29 & SURV & West & & & $T$ & & & & & $T$ & & & & & & & & & & & $\mathrm{~T}$ & & & FY04 \\
\hline 699-S12-3 & SURV & East & & & $\mathrm{T}$ & & & & & $\mathrm{T}$ & & & & & & & & & & & $\mathrm{T}$ & & & FY04 \\
\hline 699-S19-11 & SURV & $\mathrm{RCHN}$ & & & $\mathrm{T}$ & & & & & $\mathrm{T}$ & & & & & & & & & & & $\mathrm{T}$ & & & FY04 \\
\hline 699-S19-E13 & SURV & East & $\mathrm{s}$ & A & $S$ & & A & & & $S$ & A & & & Af & & A & A & & A & A & $S$ & & & River transect \\
\hline 699-S19-E14 & SURV & $\mathrm{RCHN}$ & & & $\mathrm{T}$ & & & & & $\mathrm{T}$ & & & & & & & & & & & $\mathrm{T}$ & & & FY04 \\
\hline 699-S22-E9A & SURV & $\mathrm{RCHN}$ & & & A & & & & & A & & & & & & & & & & & A & & & \\
\hline 699-S22-E9C & SURV & $\mathrm{RCHN}$ & & & & & & & & $\mathrm{T}$ & & & & & & & & & & & $\mathrm{T}$ & & & FY04 \\
\hline 699-S2-34B & SURV & East & A & & A & & & & & A & & & A & Af/u & & & & A & & & A & & & \\
\hline 699-S24-19P & SURV & Basalt & $\mathrm{T}$ & & $\mathrm{T}$ & & & & & $\mathrm{T}$ & & & & Tf & & & & & & & $\mathrm{T}$ & & & FY04. Levey Interbed (b). \\
\hline 699-S24-19Q & SURV & $\mathrm{RCHN}$ & $\mathrm{T}$ & & $\mathrm{T}$ & & & & & $\mathrm{T}$ & & & & $\mathrm{Tf}$ & & & & & & & $\mathrm{T}$ & & & FY04 \\
\hline 699-S27-E12A & LTMC & HRLF & & & A & & & & & & & & & & & & & & & & & & A & \\
\hline 699-S27-E12A & SURV & $\mathrm{RCHN}$ & & A & A & & & & & A & & & & & & & & & & & & & A & \\
\hline 699-S27-E14 & SURV & $\mathrm{RCHN}$ & & & $S$ & & & & & $S$ & & & & & & & & & & & $S$ & A & $S$ & \\
\hline
\end{tabular}




\begin{tabular}{|c|c|c|c|c|c|c|c|c|c|c|c|c|c|c|c|c|c|c|c|c|c|c|c|c|}
\hline WELL & PROG & PROJ & 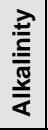 & $\frac{\pi}{\frac{\pi}{0}}$ & 号 & 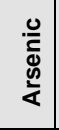 & 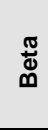 & 屯े & $\begin{array}{l}\frac{0}{0} \\
\frac{0}{5} \\
\text { Jे }\end{array}$ & ㅇ & 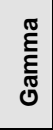 & $\begin{array}{l}\text { 움 } \\
\infty \\
\text { 오 }\end{array}$ & 昰 & $\stackrel{0}{0}$ & $\begin{array}{l}\frac{\infty}{0} \\
\frac{\Phi}{\Phi} \\
\frac{\hbar}{\alpha}\end{array}$ & $\begin{array}{l}\text { के } \\
\frac{1}{\omega}\end{array}$ & $\begin{array}{l}\stackrel{8}{\dot{d}} \\
\stackrel{0}{\circ}\end{array}$ & $\stackrel{\text { OD }}{\circ}$ & 온 & ’̊ & 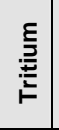 & 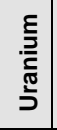 & $\stackrel{\nwarrow}{\supset}$ & Other/comments \\
\hline 699-S27-E9A & SURV & $\mathrm{RCHN}$ & & & A & & & & & A & & & & & & & & & & & A & & A & \\
\hline 699-S27-E9B & SURV & $\mathrm{RCHN}$ & & & & & & & & A & & & & & & & & & & & A & & A & Deep unconfined (b) \\
\hline 699-S27-E9C & SURV & $\mathrm{RCHN}$ & & & & & & & & $\mathrm{T}$ & & & & & & & & & & & $\mathrm{T}$ & & & FY04 \\
\hline 699-S28-E0 & SURV & $\mathrm{RCHN}$ & & A & A & & A & & & A & & & & & & & & & & & A & & A & \\
\hline 699-S28-E12 & LTMC & HRLF & & & A & & & & & & & & & & & & & & & & & & A & \\
\hline 699-S28-E12 & SURV & $\mathrm{RCHN}$ & & & & & & & & A & & & & & & & & & & & & A & A & \\
\hline 699-S28-E13A & LTMC & HRLF & & & A & & & & & & & & & & & & & & & & & & A & \\
\hline 699-S28-E13A & SURV & RCHN & & & A & & & & & A & & & & & & & & & & & & & A & \\
\hline 699-S29-E10A & LTMC & HRLF & & & A & & & & & & & & & & & & & & & & & & A & \\
\hline 699-S29-E10A & SURV & $\mathrm{RCHN}$ & & & A & & & & & A & & & & & & & & & & & & & A & \\
\hline 699-S29-E11 & LTMC & HRLF & & & A & & & & & & & & & & & & & & & & & & A & \\
\hline 699-S29-E11 & SURV & RCHN & & & & & & & & A & & & & & & & & & & & & A & & \\
\hline 699-S29-E12 & LTMC & HRLF & & & A & & & & & & & & & & & & & & & & & & A & \\
\hline 699-S29-E12 & SURV & $\mathrm{RCHN}$ & & & & & & & & A & & & & & & & & & & & & & & \\
\hline 699-S29-E13A & LTMC & HRLF & & & A & & & & & & & & & & & & & & & & & & A & \\
\hline 699-S29-E13A & SURV & $\mathrm{RCHN}$ & & & A & & & & & A & & & & & & & & & & & & & A & \\
\hline 699-S29-E16A & SURV & $\mathrm{RCHN}$ & & & A & & & & & Q & & & & & & & & & & & Q & A & A & \\
\hline 699-S29-E16B & SURV & $\mathrm{RCHN}$ & & & & & & & & A & & & & & & & & & & & A & & & Deep unconfined (b) \\
\hline 699-S29-E16C & SURV & $\mathrm{RCHN}$ & & & & & & & & A & & & & & & & & & & & A & & & Confined Ringold (b). \\
\hline 699-S30-E10A & LTMC & HRLF & & & A & & & & & & & & & & & & & & & & & & A & \\
\hline 699-S30-E10A & SURV & $\mathrm{RCHN}$ & & & A & & & & & A & & & & & & & & & & & & A & A & \\
\hline 699-S30-E10B & LTMC & HRLF & & & A & & & & & & & & & & & & & & & & & & A & \\
\hline 699-S30-E10B & SURV & RCHN & & & & & & & & A & & & & & & & & & & & & & & \\
\hline 699-S30-E11A & LTMC & HRLF & & & A & & & & & & & & & & & & & & & & & & A & \\
\hline 699-S30-E11A & SURV & $\mathrm{RCHN}$ & & & A & & & & & A & & & & & & & & & & & & & A & \\
\hline 699-S30-E15A & $\mathrm{DOH}$ & $600 \mathrm{DOH}$ & & A & A & & A & & & & A & & & & & & & & & & A & & & \\
\hline 699-S30-E15A & SURV & $\mathrm{RCHN}$ & & A & A & & A & & & A & & & & & & & & & & & A & A & & \\
\hline 699-S31-1 & SURV & $\mathrm{RCHN}$ & & A & A & & A & & & A & & & A & & & & & & & & A & & A & \\
\hline 699-S31-E10A & LTMC & HRLF & & & A & & & & & & & & & & & & & & & & & & A & \\
\hline 699-S31-E10A & SURV & $\mathrm{RCHN}$ & & & & & & & & A & & & & & & & & & & & & & A & \\
\hline 699-S31-E10B & SURV & $\mathrm{RCHN}$ & & & & & & & & A & & & & & & & A & & & & & A & A & \\
\hline
\end{tabular}




\begin{tabular}{|c|c|c|c|c|c|c|c|c|c|c|c|c|c|c|c|c|c|c|c|c|c|c|c|c|}
\hline WELL & PROG & PROJ & 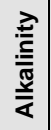 & $\frac{\frac{\pi}{0}}{\frac{0}{\alpha}}$ & $\frac{\mathscr{0}}{\frac{0}{c}}$ & 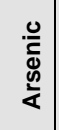 & 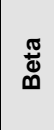 & 屯ัँ & $\begin{array}{l}\frac{0}{\circ} \\
\frac{0}{\mathrm{~T}} \\
\text { ปे }\end{array}$ & ㅇ & 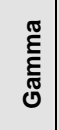 & $\begin{array}{l}0 \\
0 \\
\infty \\
ㅁ \\
\text { I }\end{array}$ & $\frac{\text { న }}{1}$ & $\underline{0}$ & $\begin{array}{l}\frac{0}{0} \\
\frac{0}{\Phi} \\
\frac{5}{\alpha}\end{array}$ & $\begin{array}{l}\frac{8}{0} \\
\frac{1}{5}\end{array}$ & 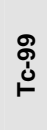 & 里 & O & 음 & 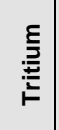 & 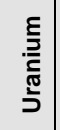 & § & Other/comments \\
\hline 699-S31-E10C & LTMC & HRLF & & & A & & & & & & & & & & & & & & & & & & A & \\
\hline 699-S31-E10C & SURV & $\mathrm{RCHN}$ & & & & & & & & A & & & & & & & & & & & $\mathrm{T}$ & & A & FY04 \\
\hline 699-S31-E10D & LTMC & HRLF & & & A & & & & & & & & & & & & & & & & & & A & \\
\hline 699-S31-E10D & SURV & $\mathrm{RCHN}$ & & & & & & & & A & & & & & & & & & & & & & A & \\
\hline 699-S31-E10E & SURV & $\mathrm{RCHN}$ & & & & & & & & A & & & & & & & & & & & $\mathrm{T}$ & & $\mathrm{A}$ & FY04. Deep unconfined (b) \\
\hline 699-S31-E11 & LTMC & HRLF & & & A & & & & & & & & & & & & & & & & & & A & \\
\hline 699-S31-E11 & SURV & $\mathrm{RCHN}$ & & & A & & & & & A & & & & & & & & & & & & & A & \\
\hline 699-S31-E8A & $\mathrm{DOH}$ & $600 \mathrm{DOH}$ & & A & A & & A & & & & A & & A & & & & A & & & & A & & & \\
\hline 699-S31-E8A & SURV & $\mathrm{RCHN}$ & & A & A & & A & & & A & & & $\mathrm{A}$ & & & & A & & & & A & A & A & \\
\hline 699-S3-25 & SURV & East & & & $\mathrm{T}$ & & & & & $\mathrm{T}$ & & & & & & & & & & & $T$ & & & FY04 \\
\hline 699-S32-E11 & SURV & RCHN & & $A$ & A & & & & & A & & & & & & & & & & & & A & & \\
\hline 699-S32-E13A & SURV & $\mathrm{RCHN}$ & A & & A & & & & & $Q$ & & & & Af & & & & & & & $Q$ & A & & \\
\hline 699-S32-E13B & SURV & $\mathrm{RCHN}$ & & A & & & & & & A & & & & & & & & & & & & A & A & \\
\hline 699-S34-E10 & $\mathrm{DOH}$ & $600 \mathrm{DOH}$ & & $\mathrm{A}$ & A & & $\mathrm{A}$ & & & & A & & & & & & & & & & A & & & \\
\hline 699-S34-E10 & SURV & $\mathrm{RCHN}$ & & & A & & & & & A & & & & & & & & & & & A & A & A & \\
\hline 699-S34-E15 & SURV & $\mathrm{RCHN}$ & & & A & & & & & A & & & & & & & & & & & A & & & \\
\hline 699-S36-E13A & SURV & RCHN & & & $\mathrm{A}$ & & & & & A & & & & & & & & & & & A & & A & \\
\hline 699-S37-E14 & $\mathrm{DOH}$ & $600 \mathrm{DOH}$ & & $S$ & S & & $S$ & & & & $S$ & & & & & & & & & & $S$ & & & $A: C 14$ \\
\hline 699-S37-E14 & SURV & $\mathrm{RCHN}$ & $\mathrm{A}$ & A & A & & $\mathrm{A}$ & & & $Q$ & & & & Af & & & & & & & $Q$ & & A & \\
\hline 699-S38-E11 & SURV & $\mathrm{RCHN}$ & & & A & & & & & A & & & & & & & & & & & A & & & \\
\hline 699-S38-E12A & SURV & $\mathrm{RCHN}$ & & & A & & & & & $A$ & & & & & & & & & & & $A$ & & A & \\
\hline 699-S38-E12B & SURV & $\mathrm{RCHN}$ & & & & & & & & $\mathrm{T}$ & & & & & & & & & & & $\mathrm{T}$ & & & FY04 \\
\hline 699-S3-E12 & SURV & East & A & A & $\mathrm{A}$ & & $\mathrm{A}$ & & & $A$ & A & & & Af & & A & A & & A & A & & & & River transect \\
\hline 699-S40-E13A & $\mathrm{DOH}$ & $600 \mathrm{DOH}$ & & $\mathrm{A}$ & A & & $\mathrm{A}$ & & & & A & & & & & & & & & & A & & & \\
\hline 699-S40-E13A & SURV & RCHN & & & & & & & & $Q$ & & & & & & & & & & & $Q$ & & & \\
\hline 699-S40-E14 & SURV & $\mathrm{RCHN}$ & & & & & & & & $\mathrm{s}$ & & & & & & & & & & & $\mathrm{s}$ & & & \\
\hline 699-S41-E12 & LTMC & HRLF & & & & & & Af/u & & & & & & & & & & & & & & & & \\
\hline 699-S41-E12 & SURV & $\mathrm{RCHN}$ & & & $S$ & & & & & & & & & & & & & & & & $S$ & & & \\
\hline 699-S41-E13A & SURV & $\mathrm{RCHN}$ & & & & & & & & A & & & & & & & & & & & A & & & \\
\hline 699-S41-E13B & SURV & RCHN & & & & & & & & $\mathrm{T}$ & & & & & & & & & & & $\mathrm{T}$ & & & FY04 \\
\hline 699-S41-E13C & SURV & $\mathrm{RCHN}$ & & & & & & & & $\mathrm{T}$ & & & & & & & & & & & $\mathrm{T}$ & & & FY04 \\
\hline
\end{tabular}




\begin{tabular}{|c|c|c|c|c|c|c|c|c|c|c|c|c|c|c|c|c|c|c|c|c|c|c|c|c|}
\hline WELL & PROG & PROJ & 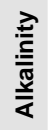 & $\frac{\frac{\pi}{0}}{\frac{0}{\alpha}}$ & $\frac{\mathscr{0}}{\frac{0}{c}}$ & 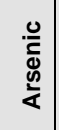 & 蛋 & 屯ัँ & $\begin{array}{l}\frac{0}{0} \\
\frac{0}{\mathrm{~T}} \\
\text { ปे }\end{array}$ & ㅇ & 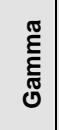 & $\begin{array}{l}\text { 유 } \\
\infty \\
\text { 모 }\end{array}$ & $\frac{\text { ลิ }}{1}$ & $\underline{0}$ & $\begin{array}{l}\frac{\infty}{0} \\
\frac{\sigma}{0} \\
\frac{5}{\alpha}\end{array}$ & $\begin{array}{l}\text { के } \\
\frac{1}{\omega}\end{array}$ & 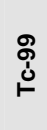 & $\stackrel{\text { 足 }}{P}$ & 음 & 음 & 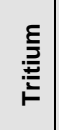 & 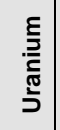 & § & Other/comments \\
\hline 699-S43-E12 & $\mathrm{DOH}$ & $600 \mathrm{DOH}$ & & A & A & & A & & & & A & & & & & & & & & & A & & & \\
\hline 699-S43-E12 & SURV & $\mathrm{RCHN}$ & & & A & & & & & A & & & & & & & & & & & A & & A & \\
\hline 699-S6-E14A & SURV & $\mathrm{RCHN}$ & & $\mathrm{T}$ & $T$ & & $\mathrm{~T}$ & & & $\mathrm{~T}$ & T & & & & & & & & & & $\mathrm{T}$ & & & FY04 \\
\hline 699-S6-E4A & CERC & $300 \mathrm{FF5}$ & & $S$ & & & $S$ & & & & $S$ & & & Sf/u & & & & & & & & $\mathrm{s}$ & $S$ & S:ABNL \\
\hline 699-S6-E4A & SURV & East & A & S & A & & s & & & s & A & & & Af & & A & & & & & A & S & $\mathrm{A}$ & $\begin{array}{l}\text { A:Puis, Uiso; S:ABNL, O\&G, } \\
\text { TPH }\end{array}$ \\
\hline 699-S6-E4B & SURV & East & & $T$ & $T$ & & $T$ & & & $T$ & $\mathrm{~T}$ & & & & & & & & & & $T$ & & & FY04 \\
\hline 699-S6-E4CS & SURV & East & & & & & & & & A & & & & & & & & & & & A & A & & Deep unconfined (b) \\
\hline 699-S6-E4CT & SURV & East & & & & & & & & $A$ & & & & & & & & & & & A & A & & Deep unconfined (b) \\
\hline 699-S6-E4D & SURV & East & & A & & & A & & & A & & & & & & & & & & & A & A & & \\
\hline 699-S8-19 & SURV & East & & & $\mathrm{T}$ & & & & & $\mathrm{T}$ & & & & & & & & & & & $\mathrm{T}$ & & & FY04 \\
\hline C3164 & SURV & $100 \mathrm{~N}$ & A & A & A & & A & & & & A & & & Af & & & & & & & A & & & $\begin{array}{l}\text { A:O\&G, TPH. Hanford } \\
\text { Generating Plant. }\end{array}$ \\
\hline HANSPR-28-2 & SESP & Spring Seep & & & A & & & & & & & & & & & & & & & & & & & \\
\hline HANSPRDR-28-2 & SESP & Spring Seep & & & A & & & & & & & & & & & & & & & & & & & \\
\hline HANSPRUR-28-2 & SESP & Spring Seep & & & A & & & & & & & & & & & & & & & & & & & \\
\hline SB-037-1 & LTMC & 100BC5 & & A & A & & A & & & & & & & Af & & A & & & & & A & & & \\
\hline SB-038-3 & LTMC & 100BC5 & & A & A & & A & & & & & & & Af & & A & & & & & A & & & \\
\hline SB-038-3 & SESP & Spring Seep & & & A & & & & & & & & & & & & & & & & & & A & \\
\hline SB-039-2 & SESP & Spring Seep & & & $\mathrm{A}$ & & & & & & & & & & & & & & & & & & $\mathrm{A}$ & \\
\hline \begin{tabular}{|l|} 
SD-102-1 \\
\end{tabular} & CERC & 100HR3 & & A & A & & A & & & & & & & $\mathrm{Af} / \mathrm{u}$ & & & & & & & A & & & \\
\hline SD-102-1 & SESP & Spring Seep & & & A & & & & & & & & & & & & & & & & & & & \\
\hline SD-110-1 & CERC & 100HR3 & & A & A & & A & & & & & & & $\mathrm{Af} / \mathrm{u}$ & & & & & & & A & & & \\
\hline SD-110-1 & SESP & Spring Seep & & & $\mathrm{A}$ & & & & & & & & & & & & & & & & & & & \\
\hline SD-110-2 & CERC & 100HR3 & & A & $\mathrm{A}$ & & $\mathrm{A}$ & & & & & & & $\mathrm{Af} / \mathrm{u}$ & & & & & & & A & & & \\
\hline SD-98-1 & CERC & 100HR3 & & A & A & & A & & & & & & & $\mathrm{Af} / \mathrm{u}$ & & & & & & & A & & & \\
\hline \begin{tabular}{|l|} 
SF-187-1 \\
\end{tabular} & LTMC & 100FR3 & & $\mathrm{A}$ & $\mathrm{A}$ & & $\mathrm{A}$ & & & & & & & Af & & A & & & & & A & & A & \\
\hline SF-190-4 & LTMC & 100FR3 & & $\mathrm{A}$ & $\mathrm{A}$ & & $A$ & & & & & & & $\mathrm{Af}$ & & A & & & & & $A$ & & A & \\
\hline SF-207-1 & LTMC & 100FR3 & & A & $\mathrm{A}$ & & $A$ & & & & & & & Af & & $A$ & & & & & A & & A & \\
\hline SF-207-1 & SESP & Spring Seep & & & A & & & & & & & & & & & & & & & & & & & \\
\hline SF-211-1 & LTMC & 100FR3 & & A & A & & $\mathrm{A}$ & & & & & & & Af & & $\mathrm{A}$ & & & & & A & & A & \\
\hline SH-144-1 & CERC & 100HR3 & & A & A & & $A$ & & & & & & & $\mathrm{Af} / \mathrm{u}$ & & & & & & & $A$ & & & \\
\hline
\end{tabular}




\begin{tabular}{|c|c|c|c|c|c|c|c|c|c|c|c|c|c|c|c|c|c|c|c|c|c|c|c|c|}
\hline WELL & PROG & PROJ & 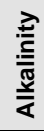 & $\frac{\frac{\pi}{0}}{\frac{0}{\alpha}}$ & 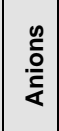 & 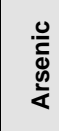 & 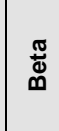 & 志 & 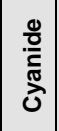 & 웅 & 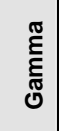 & $\begin{array}{l}0 \\
0 \\
\infty \\
\frac{0}{I}\end{array}$ & $\frac{\mathbb{2}}{\mathbf{T}}$ & $\underline{0}$ & $\begin{array}{l}\frac{\infty}{0} \\
\frac{\bar{\sigma}}{0} \\
\frac{c}{\alpha}\end{array}$ & $\begin{array}{l}\stackrel{8}{0} \\
\frac{\grave{d}}{\omega}\end{array}$ & \begin{tabular}{|l}
$\stackrel{8}{Q}$ \\
$\dot{\dot{\theta}}$
\end{tabular} & $\stackrel{\mathscr{P}}{\circ}$ & $\begin{array}{l}\mathscr{\circ} \\
\stackrel{\circ}{\circ}\end{array}$ & ํㅗㅁ & 丞 & 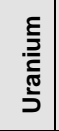 & § & Other/comments \\
\hline SH-145-1 & CERC & 100HR3 & & A & A & & A & & & & & & & Af/u & & & & & & & A & & & \\
\hline SH-145-1 & SESP & Spring Seep & & & A & & & & & & & & & & & & & & & & & & A & \\
\hline SH-150-1 & CERC & $100 \mathrm{HR} 3$ & & A & A & & A & & & & & & & Af/u & & & & & & & A & & & \\
\hline $\mathrm{SH}-152-2$ & CERC & 100HR3 & & A & A & & A & & & & & & & Af/u & & & & & & & A & & & \\
\hline SH-152-2 & SESP & Spring Seep & & & A & & & & & & & & & & & & & & & & & & & \\
\hline SH-153-1 & CERC & 100HR3 & & A & A & & A & & & & & & & $\mathrm{Af} / \mathrm{u}$ & & & & & & & A & & & \\
\hline SK-057-3 & CERC & 100KR4 & & A & A & & A & & & & A & & & Af/u & & & & & & & A & & & \\
\hline SK-063-1 & SESP & Spring Seep & & & A & & & & & & & & & & & & & & & & & & A & \\
\hline SK-077-1 & CERC & 100KR4 & & A & A & & A & & & & A & & & Af/u & & & & & & & A & & & \\
\hline SK-077-1 & SESP & Spring Seep & & & A & & & & & & & & & & & & & & & & & & A & \\
\hline SK-082-2 & CERC & 100KR4 & & A & A & & A & & & & A & & & Af/u & & & & & & & A & & & \\
\hline$S N-008-13$ & SESP & Spring Seep & & & A & & & & & & & & & & & & & & & & & & & \\
\hline SN-199N-46 & SESP & Spring Seep & & & A & & & & & & & & & & & & & & & & & & & \\
\hline SST(B)-NEW-1 & RCRA & SST(B) & $\mathrm{Q}$ & Q & $\mathrm{Q}$ & & Q & & Q & & $\mathrm{Q}$ & & & Qf & & & $Q$ & $\mathrm{Q}$ & Q4 & Q4 & Q & Q & & \\
\hline SST(B)-NEW-2 & RCRA & SST(B) & $Q$ & $Q$ & $\mathrm{Q}$ & & $Q$ & & $Q$ & & $Q$ & & & Qf & & & $Q$ & $Q$ & Q4 & Q4 & $Q$ & $Q$ & & \\
\hline SST(B)-NEW-3 & RCRA & $\operatorname{SST}(\mathrm{B})$ & $\mathrm{Q}$ & $\mathrm{Q}$ & $\mathrm{Q}$ & & $\mathrm{Q}$ & & $\mathrm{Q}$ & & $\mathrm{Q}$ & & & Qf & & & $Q$ & $Q$ & Q4 & Q4 & $\mathrm{Q}$ & $\mathrm{Q}$ & & \\
\hline SST(T)-NEW-1 & RCRA & $\operatorname{SST}(\mathrm{T})$ & $\mathrm{Q}$ & Q & $Q$ & & $\mathrm{~s}$ & & & & $\mathrm{Q}$ & & & Qf & & & $\mathrm{Q}$ & & & & $Q$ & & & \\
\hline SST(TX-TY)-NEW-1 & RCRA & SST(TX/TY) & $\mathrm{Q}$ & $\mathrm{Q}$ & $\mathrm{Q}$ & & $\mathrm{Q}$ & & & & & & $\mathrm{Q}$ & Qf & & & $Q$ & & & & $Q$ & & & \\
\hline SST(TX-TY)-NEW-1 & RCRA & SST(TX/TY) & $Q$ & $Q$ & $Q$ & & $Q$ & & & & & & $Q$ & Qf & & & $Q$ & & & & $Q$ & & & \\
\hline
\end{tabular}


Table A.2. Aquifer Sampling Tube Sampling and Analysis Schedule (FY 2002)

\begin{tabular}{|c|c|c|c|c|c|c|c|c|c|}
\hline \multirow[b]{2}{*}{$\begin{array}{c}\text { Sample Location } \\
\text { Name }\end{array}$} & \multirow[b]{2}{*}{$\begin{array}{l}\text { HEIS Well } \\
\text { ID No. }\end{array}$} & \multirow[b]{2}{*}{ Area } & \multicolumn{4}{|c|}{ Offsite } & \multicolumn{3}{|c|}{ Onsite } \\
\hline & & & صَّ & 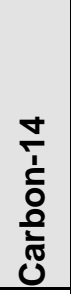 & $\begin{array}{l}8 \\
\frac{1}{5} \\
\text { के }\end{array}$ & 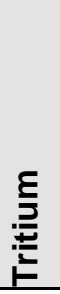 & 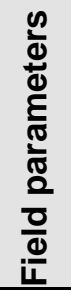 & 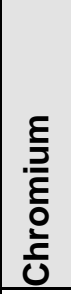 & 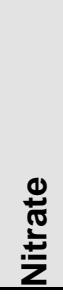 \\
\hline 04-S & B8124 & $100 \mathrm{~B}$ & & & & & 1 & & \\
\hline 04-M & B8123 & $100 \mathrm{~B}$ & & & & & 1 & & \\
\hline 04-D & B8122 & $100 \mathrm{~B}$ & 1 & & 1 & 1 & 1 & 1 & 1 \\
\hline $05-S$ & B8127 & $100 \mathrm{~B}$ & & & & & 1 & & \\
\hline 05-M & B8126 & $100 \mathrm{~B}$ & & & & & 1 & & \\
\hline $05-\mathrm{D}$ & B8125 & $100 \mathrm{~B}$ & 1 & & 1 & 1 & 1 & 1 & 1 \\
\hline $06-S$ & B8130 & $100 \mathrm{~B}$ & & & & & 1 & & \\
\hline 06-M & B8129 & $100 \mathrm{~B}$ & & & & & 1 & & \\
\hline $06-D$ & B8128 & $100 \mathrm{~B}$ & 1 & & 1 & 1 & 1 & 1 & 1 \\
\hline 07-M & B8132 & $100 \mathrm{~B}$ & & & & & 1 & & \\
\hline 07-D & B8131 & $100 \mathrm{~B}$ & 1 & & 1 & 1 & 1 & 1 & 1 \\
\hline $14-S$ & B8154 & $100 \mathrm{~K}$ & & & & & 1 & & \\
\hline $14-\mathrm{M}$ & B8153 & $100 \mathrm{~K}$ & & & & & 1 & & \\
\hline 14-D & B8152 & $100 \mathrm{~K}$ & 1 & & 1 & 1 & 1 & 1 & 1 \\
\hline $17-M$ & B8162 & $100 \mathrm{~K}$ & & & & & 1 & & \\
\hline $17-D$ & B8161 & $100 \mathrm{~K}$ & & & & 1 & 1 & 1 & 1 \\
\hline $18-S$ & B8204 & $100 \mathrm{~K}$ & & 1 & & & 1 & 1 & \\
\hline 22-M & B8215 & $100 \mathrm{~K}$ & & & & & 1 & & \\
\hline 22-D & B8214 & $100 \mathrm{~K}$ & 1 & & 1 & 1 & 1 & 1 & \\
\hline 23-M & B8218 & $100 \mathrm{~K}$ & & & & & 1 & & \\
\hline 23-D & B8217 & $100 \mathrm{~K}$ & & & & & 1 & 1 & \\
\hline DK-04-2 & B8526 & $100 \mathrm{~K}$ & & & & & 1 & 1 & \\
\hline DK-04-3 & B8527 & $100 \mathrm{~K}$ & & & & & 1 & & \\
\hline $25-D$ & B8223 & $100 \mathrm{~N}$ & & & & 1 & 1 & 1 & \\
\hline DD-50-1 & B8515 & $100 \mathrm{D}$ & & & & & 1 & & \\
\hline DD-50-2 & B8516 & $100 \mathrm{D}$ & & & & & 1 & & \\
\hline DD-50-3 & B8517 & $100 \mathrm{D}$ & & & & & 1 & & \\
\hline DD-50-4 & B8518 & $100 \mathrm{D}$ & & & & 1 & 1 & 1 & \\
\hline
\end{tabular}




\begin{tabular}{|c|c|c|c|c|c|c|c|c|c|}
\hline \multirow[b]{2}{*}{$\begin{array}{c}\text { Sample Location } \\
\text { Name }\end{array}$} & \multirow[b]{2}{*}{$\begin{array}{l}\text { HEIS Well } \\
\text { ID No. }\end{array}$} & \multirow[b]{2}{*}{ Area } & \multicolumn{4}{|c|}{ Offsite } & \multicolumn{3}{|c|}{ Onsite } \\
\hline & & & هั & $\begin{array}{l}\mathbf{J} \\
\dot{L} \\
\delta \\
\frac{0}{2} \\
\mathbb{J}\end{array}$ & $\begin{array}{l}8 \\
\stackrel{1}{\infty} \\
\end{array}$ & $\stackrel{\sum}{\underline{\Sigma}}$ & 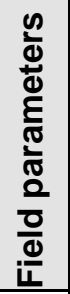 & 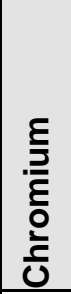 & $\stackrel{0}{\frac{0}{\pi}}$ \\
\hline DD-44-3 & B8509 & $100 \mathrm{D}$ & & & & & 1 & & \\
\hline DD-44-4 & B8510 & $100 \mathrm{D}$ & & & & 1 & 1 & 1 & \\
\hline DD-39-1 & B8479 & $100 \mathrm{D}$ & & & & & 1 & & \\
\hline DD-39-2 & B8480 & $100 \mathrm{D}$ & & & & & 1 & & \\
\hline DD-39-3 & B8481 & $100 \mathrm{D}$ & & & & & 1 & & \\
\hline DD-39-4 & B8482 & $100 \mathrm{D}$ & & & & & 1 & 1 & \\
\hline $36-S$ & B8258 & $100 \mathrm{D}$ & & & & & 1 & & \\
\hline 36-M & B8257 & $100 \mathrm{D}$ & & & & & 1 & & \\
\hline $36-D$ & B8256 & $100 \mathrm{D}$ & & & & & 1 & 1 & \\
\hline 38-M & B8263 & $100 \mathrm{D}$ & & & & & 1 & & \\
\hline $38-D$ & B8262 & $100 \mathrm{D}$ & & & & & 1 & 1 & \\
\hline $42-S$ & B8276 & $100 \mathrm{H}$ & & & & & 1 & & \\
\hline $42-M$ & B8275 & $100 \mathrm{H}$ & & & & & 1 & & \\
\hline $42-D$ & B8274 & $100 \mathrm{H}$ & & & & & 1 & 1 & \\
\hline 43-M & B8278 & $100 \mathrm{H}$ & & & & & 1 & & \\
\hline 43-D & B8277 & $100 \mathrm{H}$ & & & & & 1 & 1 & \\
\hline $45-S$ & B8285 & $100 \mathrm{H}$ & & & & & 1 & & \\
\hline $44-M$ & B8281 & $100 \mathrm{H}$ & & & & & 1 & & \\
\hline 44-D & B8280 & $100 \mathrm{H}$ & & & & & 1 & 1 & \\
\hline $45-M$ & B8284 & $100 \mathrm{H}$ & & & & & 1 & & \\
\hline $45-D$ & B8283 & $100 \mathrm{H}$ & & & & & 1 & 1 & \\
\hline $46-D$ & B8286 & $100 \mathrm{H}$ & 1 & & 1 & & 1 & 1 & 1 \\
\hline 47-M & B8290 & $100 \mathrm{H}$ & & & & & 1 & & \\
\hline 47-D & B8289 & $100 \mathrm{H}$ & 1 & & & & 1 & 1 & 1 \\
\hline $48-S$ & B8294 & $100 \mathrm{H}$ & & & & & 1 & & \\
\hline 48-M & B8293 & $100 \mathrm{H}$ & & & & & 1 & & \\
\hline 48-D & B8292 & $100 \mathrm{H}$ & 1 & & 1 & & 1 & 1 & 1 \\
\hline $49-S$ & B8297 & $100 \mathrm{H}$ & & & & & 1 & & \\
\hline 49-M & B8296 & $100 \mathrm{H}$ & & & & & 1 & & \\
\hline 49-D & B8295 & $100 \mathrm{H}$ & 1 & & 1 & & 1 & 1 & \\
\hline
\end{tabular}




\begin{tabular}{|c|c|c|c|c|c|c|c|c|c|}
\hline \multirow[b]{2}{*}{$\begin{array}{c}\text { Sample Location } \\
\text { Name }\end{array}$} & \multirow[b]{2}{*}{$\begin{array}{l}\text { HEIS Well } \\
\text { ID No. }\end{array}$} & \multirow[b]{2}{*}{ Area } & \multicolumn{4}{|c|}{ Offsite } & \multicolumn{3}{|c|}{ Onsite } \\
\hline & & & ల్ & 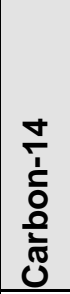 & $\begin{array}{l}8 \\
\stackrel{1}{\infty} \\
\end{array}$ & 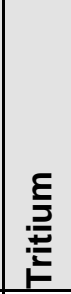 & 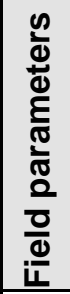 & 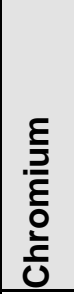 & 莺 \\
\hline $50-S$ & B8300 & $100 \mathrm{H}$ & & & & & 1 & & \\
\hline $50-M$ & B8299 & $100 \mathrm{H}$ & & & & & 1 & & \\
\hline $50-\mathrm{D}$ & B8298 & $100 \mathrm{H}$ & & & & & 1 & 1 & 1 \\
\hline $51-S$ & B8303 & $100 \mathrm{H}$ & & & & & 1 & & \\
\hline 51-M & B8302 & $100 \mathrm{H}$ & & & & & 1 & & \\
\hline 51-D & B8301 & $100 \mathrm{H}$ & & & & & 1 & 1 & 1 \\
\hline $52-S$ & B8306 & $100 \mathrm{H}$ & & & & & 1 & & \\
\hline $52-M$ & B8305 & $100 \mathrm{H}$ & & & & & 1 & & \\
\hline $52-\mathrm{D}$ & B8304 & $100 \mathrm{H}$ & & & & & 1 & 1 & \\
\hline $55-S$ & B8315 & $100 \mathrm{H}$ & & & & & 1 & & \\
\hline $55-\mathrm{M}$ & B8314 & $100 \mathrm{H}$ & & & & & 1 & & \\
\hline $55-\mathrm{D}$ & B8313 & $100 \mathrm{H}$ & & & & & 1 & 1 & \\
\hline $58-S$ & B8324 & $100 \mathrm{H}$ & & & & & 1 & & \\
\hline 58-M & B8323 & $100 \mathrm{H}$ & & & & & 1 & & \\
\hline $58-D$ & B8322 & $100 \mathrm{H}$ & & & & & 1 & 1 & \\
\hline $74-S ?$ & B8372 & $100 \mathrm{~F}$ & & & & & 1 & & \\
\hline 74-M? & B8371 & $100 \mathrm{~F}$ & & & & & 1 & & \\
\hline 74-D? & B8370 & $100 \mathrm{~F}$ & & & & & 1 & 1 & 1 \\
\hline $75-S ?$ & B8375 & $100 \mathrm{~F}$ & & & & & 1 & & \\
\hline 75-M? & B8374 & $100 \mathrm{~F}$ & & & & & 1 & & \\
\hline $75-D ?$ & B8373 & $100 \mathrm{~F}$ & & & & & 1 & 1 & 1 \\
\hline
\end{tabular}




\section{Distribution}

No. of

Copies

OFFSITE

2 Confederated Tribes of the Umatilla Indian Reservation

Environmental Planning/Rights Protection

P.O. Box 638

Pendleton, OR 97801

ATTN: S. Harris

J. H. Richards

R. A. Danielson

Washington State Department of Health

5508 Englewood Avenue

Yakima, WA 98908

R. Jim, Manager

Environmental Restoration/Waste

Management Program

Confederated Tribes and Bands of the

Yakama Nation

2802 Main Street

Union Gap, WA 98903

L. Seelatsee

Wanapam People

Grant County P.U.D.

30 "C" Street, S.W.

P.O. Box 878

Ephrata, WA 98823

P. Sobotta, Interim Director

Nez Perce Tribe

P.O. Box 365

Lapwai, ID 83540
No. of

Copies

S. VanVerst

Washington State Department of Health

P.O. Box 47827

Olympia, WA 98504-7827

\section{ONSITE}

16 DOE Richland Operations Office

B. L. Foley

$\mathrm{H} 0-12$

M. J. Furman (8)

R. D. Hildebrand

A5-13

A5-13

J. G. Morse

A5-13

J. P. Sands

$\mathrm{H} 0-12$

K. M. Thompson

A5-13

A. C. Tortoso

H0-12

Public Reading Room (2)

$\mathrm{H} 2-53$

2 DOE Office of River Protection

R. W. Lober

H6-60

R. M. Yasek

H6-60

Bechtel Hanford, Inc.

B. H. Ford

CH2M HILL Hanford Group, Inc.

F. J. Anderson

A.J. Knepp

$\mathrm{H} 0-22$

*Sent announcement of Internet availability at http://hanford-site.pnl.gov/groundwater

Distr.1 
No. of

Copies

6 CH2M HILL Hanford, Inc.

J. V. Borghese

H0-19

W. J. McMahon

H9-03

R. F. Raidl

H9-02

V. J. Rohay

H0-19

L. C. Swanson

J. P. Zoric

GTS Duratek

M. G. Gardner

S. H. Worley

H9-02

X5-53

3 Fluor Hanford, Inc.
R. A. Del Mar
B. J. Dixon
C. L. Edwards
C. K. Girres
S. M. Price
F. A. Ruck
R. W. Szelmecza
J. C. Sonnichsen

No. of

Copies
K6-96

K9-33

$\begin{array}{lr}\text { J. S. Fruchter } & \text { K6-96 } \\ \text { R. W. Hanf } & *\end{array}$

M. J. Hartman (5) K6-96

P. S. Henry K6-75

F. N. Hodges K6-81

D. G. Horton K6-81

V. G. Johnson K6-96

J. L. Julya $\quad$ K6-75

J. W. Lindberg K6-81

S. P. Luttrell K6-96

J. P. McDonald K6-96

R. B. Mercer K6-96

L. F. Morasch K6-86

S. M. Narbutovskih K6-96

D. R. Newcomer K6-96

G. W. Patton *

R. E. Peterson K6-96

R. D. Price K6-96

J. T. Rieger *

R. M. Smith K6-96

D. L. Stewart K6-96

M. D. Sweeney K6-81

C. J. Thompson K6-96

E. C. Thornton K6-96

D. Vela (project file) K6-96

W. D. Webber *

B. A. Williams *

Hanford Technical Library (2) P8-55

D. B. Barnett

S. F. Conley

K6-75 